Universidade de São Paulo

Escola de Engenharia de São Carlos

\title{
RESISTÊNCIA DE INTERFACE ENTRE GEOMEMBRANAS E SOLOS ATRAVÉS DO ENSAIO DE RING SHEAR
}

Karla Maria Wingler Rebelo

Dissertação apresentada à Escola de Engenharia de São Carlos da Universidade de São Paulo, como parte dos requisitos para obtenção do título de Mestre em Geotecnia.

ORIENTADOR: Prof. Dr. Orencio Monje Vilar.

São Carlos

2003 
“(...) Os homens não têm tempo de conhecer coisa alguma.

Compram tudo prontinho nas lojas. Mas como não existem lojas de amigos, os homens não têm mais amigos. Os homens esqueceram a verdade Mas tu não a deves esquecer. Tu te tornas eternamente responsável por aquilo que cativas." (Antoine de Saint-Exupéry) 
Ao Conselho Nacional de Pesquisa e Desenvolvimento -CNPq- pela concessão da bolsa de estudos.

Ao Departamento de Engenharia Civil da Escola de Minas de Ouro Preto, em especial aos Professores Dr. Antenor Rodrigues Barbosa Jr., Dr. Jaime Florêncio Martins, Dra. Teresinha Bonucelli e Dr. Luiz Gonzaga de Araújo, pelo incentivo à pesquisa e pela amizade.

Aos Departamentos de Estrutura de Madeira e de Engenharia de Materiais pelo suporte técnico.

A Enga. Indiara Vidal e a Nòrtene Plásticos Ltda. pela doação dos materiais indispensáveis ao andamento da pesquisa.

A todos os funcionários do Departamento de Geotecnia pelo apoio técnico e pela boa convivência. Em especial aos técnicos José Luis, Oscar, Clever e aos funcionários Maristela, Álvaro e Herivelto.

A todos os professores do Departamento de Geotecnia que contribuíram não somente para $O$ andamento da pesquisa, mas também ao meu aperfeiçoamento profissional e pessoal.

A todos os amigos e colegas que fiz aqui em São Carlos, e que me ajudaram, seja com as palavras, os gestos, as atitudes ou o silêncio. Em especial aos amigos Cláudio Rodrigues, Érika Motta, Gisele Ortolani, Helano Regis, Lia Fernandes, Paulo Lodi e Paulo Rogério.

A amigo Luis Russo Neto, eu agradeço com carinho, pela ajuda moral e espiritual, e pela presença nas horas certas.

Aos Professores Dr. Lázaro Zuquette e Dr. José Carlos Ângelo Cintra pela receptividade e ajuda no Departamento, e em minha inserção na cidade de São Carlos. Ao Professor Dr. Benedito de Souza Bueno por me fornecer todo o apoio acadêmico sempre que necessário.

Ao Professor Dr. Orencio Monje Vilar, eu agradeço não somente pela orientação e pelos ensinamentos, mas pela confiança no trabalho e pela amizade e respeito que foram conquistados.

Agradeço em especial aos meus pais Wagner e Marizéa, pelo apoio e amor incondicional. Aos queridos "maninhos" e aos pequeninos Igor e Victinho, pelo carinho pueril e inocente. 
"Tua caminhada ainda não terminou....

$A$ realidade te acolhe dizendo que pela frente

- horizonte da vida necessita de tuas palavras $e$ do teu silêncio.

Se amanhã sentires saudades, lembra-te da fantasia $e$ sonha com tua próxima vitória. Vitória que todas as armas do mundo jamais conseguirão obter. porque é uma vitória que surge da paz e não do ressentimento.

É certo que irás encontrar situações tempestuosas novamente, mas haverá de ver sempre

- lado bom da chuva que cai e não a faceta do raio que destrói.

Se não consegues entender que o céu deve estar dentro de ti, é inútil buscá-lo acima das nuvens e ao lado das estrelas.

Por mais que tenhas errado e erres, para ti haverá sempre esperança, enquanto te envergonhares de teus erros.

Tu és jovem.

Atender a quem te chama é belo, lutar por quem te rejeita é quase chegar a perfeição. A juventude precisa de sonhos e se nutrir de lembranças. assim como o leito dos rios precisa da água que rola

e o coração necessita de afeto.

Não faças do amanhã o sinônimo de nunca,

nem o ontem te seja o mesmo que nunca mais.

Teus passos ficaram.

Olhes para trás... mas vá em frente pois há muitos que precisam que chegues para poderem seguir-te." 


\section{SUMÁRIO}

Lista de Figuras

Lista de Tabelas

Lista de Siglas___ xii

Lista de Símbolos_ Xiii

Resumo_xiv xiv

Abstract__ XV

Capítulo 1. Introdução___ 1

1.1. Objetivos_ 2

1.2. Estrutura da dissertação___ 3

Capítulo 2. Revisão Bibliográfica____ 4

2.1. A problemática da disposição de resíduos sólidos___ 4

2.2.. Aterros Sanitários___ 6

2.2.1. Aspectos gerais___ 6

2.2.2. Elementos estruturais básicos de um aterro___ 7

2.3. Geomembranas___ 14

$\begin{array}{ll}\text { 2.3.1. Aspectos gerais___ } & 14\end{array}$

$\begin{array}{ll}\text { 2.3.2. Propriedades gerais___ } & 18\end{array}$

2.4. Resistência ao Cisalhamento em Barreiras Impermeáveis ___ 20

2.4.1. Introdução___ 20

2.4.2. Comportamento de rupturas em aterros __ 23

2.4.3. Análise de estabilidade___ 25

2.4.4. Tipos de ensaios aplicáveis___ 29

2.4.4.1. Ensaio de cisalhamento direto___ 29

2.4.4.2. Ensaio de arrancamento___ 32

2.4.4.3. Ensaio de cisalhamento com plano inclinado___ 35

$\begin{array}{ll}\text { 2.4.4.4. Ensaio de ring shear ___ } 37 & 37\end{array}$

2.4.4.5. Ensaio de cisalhamento com mesa vibratória___ 38

2.4.5. Valores típicos de ângulos de atrito de interfaces___ $\quad 40$ 
2.4.6. Fatores condicionantes

41

Capítulo 3. Materiais e métodos 54

3. 1. Materiais utilizados 54

3.2. Caracterização das amostras 55

3.3. Ensaio de Ring Shear

3.3.1. Descrição do programa experimental

3.3.2. Descrição do ensaio

3.3.3. Moldagem dos corpos de prova 57

3.3.4. Fixação das geomembranas 61 62

3.4. Ensaio de Cisalhamento Direto 62

Capítulo 4. Apresentação e Análise dos Resultados

4.1. Ensaios de caracterização 64

4.1.1. Material granular 64

4.1.2. Solo argiloso 64

4.1.3. Geomembranas 70

4.2. Ensaios de resistência de interface entre geomembranas e areias

4.2.1. Ensaio de Ring shear 76

4.2.2. Envoltórias de resistência 89

4.2.2. 1. Efeito do tipo das geomembranas 97

4.2.3. Influência da rugosidade das geomembranas 100

4.2.4. Condição de umidade dos materiais 101

4.2.5. Comparação com ensaios de cisalhamento direto 109

4.3. Ensaios de resistência de interface entre geomembrana e solo argiloso

4.3.1. Ensaio de Ring shear 111

4.3.2. Efeito da inundação na resistência de interface 119

4.3.3. Influência do grau de compactação na resistência de interface

4.3.4. Efeito da umidade inicial do solo argiloso 136

4.3.5. Comparação com ensaios de cisalhamento direto 143

Capítulo 5 - Conclusões 150 
Apêndice

161

Apêndice A. Resultados dos Ensaios de Tração em Geomembranas

Apêndice B. Resultados dos resultados de interface. Materiais granulares. Condição seca

Apêndice C. Resultados dos resultados de interface. Materiais granulares. Cisalhamento direto

Anexo 


\section{LISTA DE FIGURAS}

- Figura 2.2.2.1. Sistema de drenagem de líquidos e percolados (TCHOCANOGLOUS et al. apUd CARVALHO, 1999)

- Figura 2.2.2.2. Drenos verticais de aterros sanitários (TIVERON et al., 1995)

- Figura 2.2.2.3. Drenos de fundação e drenos horizontais (TIVERON et al., 1995)

- Figura 2.2.2.4. Drenos de águas superficiais (TIVERON et al., 1995)

- Figura 2.2.2.5. Configuração do sistema de cobertura (SHARMA \& LEWIS, 1994)

- $\quad$ Figura 2.2.2.6. Configuração do sistema de liners (SHARMA \& LEWIS, 1994)

- Figura 2.4.1.1. Desenvolvimento de tensões de cisalhamento em liners duplos de sistemas de aterros sanitários (KOERNER, 1994)

- Figura 2.4.2.1. Comportamento típico de tensão de cisalhamento versus deslocamento para interfaces de geossintéticos (FILZ et al., 2001)

- Figura 2.4.2.2. Ruptura progressiva de liners em aterros sanitários (FILZ et al., 2001)

- Figura 2.4.3.1. Desenvolvimento da curva hiperbólica de ordem p-(GIROUD \& DARRASSE, 1993)

- Figura 2.4.4.1.1. Tipos de equipamentos de cisalhamento direto (INGOLD, 1990)

- Figura 2.4.4.1.2. Esquema da Caixa de Cisalhamento de Grande Deslocamento (SHALLENBERG \& FILZ, 1996) 
- Figura 2.4.4.2.1. Esquema ilustrativo dos ensaios de cisalhamento direto e de arrancamento

- Figura 2.4.4.2.2. Ilustração esquemática do equipamento para ensaios de arrancamento (MITCHELL et al., 1990)

- Figura 2.4.4.3.1. Equipamento modificado para ensaio de plano inclinado (IZGIN \& WASTI, 1998)

- Figura 2.4.4.4.1. Diagrama esquemático do equipamento de cisalhamento em anel e das interfaces de cisalhamento (NEGUSSEY et al., 1989)

- Figura 2.4.4.5.1. Ilustração esquemática da mesa vibratória (YEGIAN \& LAHLAF, 1992)

- Figura 2.4.6.1. Influência da tensão normal sobre a resistência de cisalhamento sob condições seca e úmida (PASQUALINI \& SANI, 1993)

- Figura 2.4.6.2. Curva tensão cisalhante versus deslocamento para PVC lisa e texturizada dado a mesma tensão normal de 200kPa (BOUAZZA, 1996)

- Figura 2.4.6.3. Variação do ângulo de atrito com tensão normal (BOUAZZA, 1996)

- Figura 3.1.1. Geomembranas utilizadas

- Figura 3.3.2.1. Comparação ente os anéis de cisalhamento original e modificado

- Figura 3.3.2.2. Detalhes do anel modificado

- Figura 3.3.2.3. Esquema do anel modificado

- Figura 3.3.2.4. Equipamento- Ring Shear

- Figura 4.1.1.1. Curva granulométrica da areia

- Figura 4.1.1.2. Resultados dos ensaios de cisalhamento direto em areia$\mathrm{CR}=0 \%$

- Figura 4.1.1.3. Resultados dos ensaios de cisalhamento direto em areia$\mathrm{CR}=57 \%$ 
- Figura 4.1.1.4. Resultados dos ensaios de cisalhamento direto em areia$C R=100 \%$

- Figura 4.1.1.5. Envoltória de resistência- Cisalhamento direto

- Figura 4.1.1.6. Resultados dos ensaios de ring shear em areia $C R=0 \%$

- Figura 4.1.1.7. Resultados dos ensaios de ring shear em areia- $C R=57 \%$ 68

- Figura 4.1.1.8. Resultados dos ensaios de ring shear em areia $-\mathrm{CR}=100 \%$ 68

- Figura 4.1.1.9. Envoltória de resistência- Ring shear 69

- Figura 4.1.2.1. Curva granulométrica do solo argiloso 70

- Figura 4.1.2.2. Resultados dos ensaios de ring shear em argila na umidade ótima e peso específico seco de 15,6 kN/m³ (GC=98\%). Ensaio inundado

- Figura 4.1.2.3. Envoltória de resistência-pico- Ring shear. Ensaio inundado

- Figura 4.1.2.4. Resultados dos ensaios de cisalhamento direto em argila na umidade ótima e peso específico seco de $15,6 \mathrm{kN} / \mathrm{m}^{3}$ (GC=98\%). Ensaio inundado

- Figura 4.1.2.5. Envoltória de resistência- pico- Cisalhamento Direto. Ensaio inundado

- Figura 4.1.2.6. Resultados dos ensaios de ring shear em argila na umidade ótima e peso específico seco de 15,6 kN/m³ (GC=98\%). Ensaio não inundado_

- Figura 4.1.2.7. Envoltória de resistência- pico- Ring shear. Ensaio não inundado.

- Figura 4.1.2.8. Resultados dos ensaios de cisalhamento direto em argila na umidade ótima e peso específico seco de $15,6 \mathrm{kN} / \mathrm{m}^{3}$ (GC=98\%). Ensaio não inundado

- Figura 4.1.2.9. Envoltória de resistência- pico- Cisalhamento Direto. Ensaio não inundado

- Figura 4.2.1.1. Resultados dos ensaios de interface areia/ PVC-CR=0\%- $1^{\mathrm{a}}$ série 
- Figura 4.2.1.2. Resultados dos ensaios de interface areia/ PVC-CR=57\%- $1^{a}$ série

- Figura 4.2.1.3. Resultados dos ensaios de interface areia/ PVC-CR $=100 \%-1^{a}$ série

- Figura 4.2.1.4. Resultados dos ensaios de interface areia/ PEAD-CR=0\%- $1^{\mathrm{a}}$ série

- Figura 4.2.1.5. Resultados dos ensaios de interface areia/ PEAD-CR $=57 \%-1^{a}$ série

- Figura 4.2.1.6. Resultados dos ensaios de interface areia/ PEAD-CR $=100 \%-1^{a}$ série

- Figura 4.2.1.7. Resultados dos ensaios de interface areia/ $P E$ linear-CR=0\%- $1^{a}$ série

- Figura 4.2.1.8. Resultados dos ensaios de interface areia/ PE linear-CR=57\%$1^{a}$ série

- Figura 4.2.1.9. Resultados dos ensaios de interface areia/ PE linear-CR=100\%$1^{\mathrm{a}}$ série

- Figura 4.2.1.10. Resultados dos ensaios de interface areia/ PEAD A- CR=0\%- $1^{a}$ série

- Figura 4.2.1.11. Resultados dos ensaios de interface areia/ PEAD A- CR=57\%$1^{a}$ série

- Figura 4.2.1.12. Resultados dos ensaios de interface areia/ PEAD A- CR=100\%$1^{a}$ série

- Figura 4.2.1.13. Resultados dos ensaios de interface areia/ PEAD AR- CR=0\%$1^{a}$ série

- Figura 4.2.1.14. Resultados dos ensaios de interface areia/ PEAD AR- CR=57\%$1^{\mathrm{a}}$ serie

- Figura 4.2.1.15. Resultados dos ensaios de interface areia/ PEAD AR$C R=100 \%-1^{a}$ série 
- $\quad$ Figura 4.2.2.1. Envoltória de resistência- $P V C /$ areia- $C R=0 \% \_90$

- $\quad$ Figura 4.2.2.2. Envoltória de resistência- PVC/areia- $C R=57 \% \_90$

- Figura 4.2.2.3. Envoltória de resistência- PVC/areia- $C R=100 \% \_91$

- Figura 4.2.2.4. Envoltória de resistência- PEAD lisa/areia- $C R=0 \% \_91$

- Figura 4.2.2.5. Envoltória de resistência- PEAD lisa/areia- $C R=57 \% \_91$

- $\quad$ Figura 4.2.2.6. Envoltória de resistência- $P E A D$ lisa/areia- $C R=100 \% \_92$

- Figura 4.2.2.7. Envoltória de resistência- $P E$ linear/areia- $C R=0 \% \_92$

- Figura 4.2.2.8. Envoltória de resistência- $P E$ linear/areia- $C R=57 \% \_92$

- Figura 4.2.2.9. Envoltória de resistência- PE linear/areia- $C R=100 \% \_93$

- Figura 4.2.2.10. Envoltória de resistência- PEAD A/areia- $C R=0 \%$

- Figura 4.2.2.11. Envoltória de resistência- PEAD A/areia- $C R=57 \% \_93$

- Figura 4.2.2.12. Envoltória de resistência- PEAD A/areia- $C R=100 \% \_94$

- $\quad$ Figura 4.2.2.13. Envoltória de resistência- PEAD AR/areia- $C R=0 \% \_94$

- $\quad$ Figura 4.2.2.14. Envoltória de resistência- PEAD AR/areia- $C R=57 \% \_94$

- $\quad$ Figura 4.2.2.15. Envoltória de resistência- PEAD AR/areia- $C R=100 \% \_95$

- Figura 4.2.2.1.1. Efeito do tipo de geomembrana- PVC/PEAD- CR=57\%___ 97

- $\quad$ Figura 4.2.2.1.2 Efeito do tipo de geomembrana- PVC/ PE linear- CR=57\%___ 98

- Figura 4.2.2.1.3. Mecanismo de transferência de tensões cisalhantes____ 99

- Figura 4.2.3.1. Influência da textura- comparação entre PEAD e PEAD A___ $\quad 100$

- Figura 4.2.3.2. Influência da textura- comparação entre PEAD e PEAD AR___ $\quad 100$

- Figura 4.2.4.1. Resultados da interface areia /PVC- condição saturada___ $\quad 102$

- Figura 4.2.4.2. Resultados da interface areia /PEAD- condição saturada___ 103

- Figura 4.2.4.3. Resultados da interface areia /PELMD- condição saturada___ $\quad 105$

- Figura 4.2.4.4. Resultados da interface areia /PEAD A- condição saturada__ $\quad 106$

- Figura 4.2.4.5. Resultados da interface areia /PEAD AR- condição saturada_ $\quad 107$

- Figura 4.3.1.1. Curvas tensão cisalhante e deformação volumétrica versus deslocamento- interface argila/PVC- solo na umidade ótima, GC=98\%- ensaio não inundado 
- Figura 4.3.1.2. Envoltórias de resistência- PVC/argila- solo na umidade ótima, GC=98\%- ensaio não inundado

- Figura 4.3.1.3. Curvas tensão cisalhante e deformação volumétrica versus deslocamento- interface argila/PEAD- solo na umidade ótima, GC=98\%- ensaio não inundado

- Figura 4.3.1.4. Envoltórias de resistência- PEAD/argila- solo na umidade ótima, GC=98\%- ensaio não inundado

- Figura 4.3.1.5. Curvas tensão cisalhante e deformação volumétrica versus deslocamento- interface argila/PE linear- solo na umidade ótima, GC=98\%ensaio não inundado

- Figura 4.3.1.6. Envoltórias de resistência- PELMD/argila- solo na umidade ótima, GC=98\%- ensaio não inundado.

- Figura 4.3.1.7. Curvas tensão cisalhante e deformação volumétrica versus deslocamento- interface argila/PEAD AR- solo na umidade ótima, GC=98\%ensaio não inundado

- Figura 4.3.1.8. Envoltórias de resistência- PEAD AR/argila- solo na umidade ótima, GC=98\%- ensaio não inundado

- Figura 4.3.1.9. Verificação da influência da textura- PEAD AR/PEAD lisa

- Figura 4.3.1.10. Foto da superfície do solo após cisalhamento com geomembrana de PEAD lisa

- Figura 4.3.1.11. Foto da superfície do solo após cisalhamento com geomembrana de PEAD AR

- Figura 4.3.2.1. Curvas tensão cisalhante e deformação volumétrica versus deslocamento- PVC/argila- solo na umidade ótima, GC=98\%/ ensaio inundado_

- Figura 4.3.2.2. Comparação entre condição não inundada e inundada- solo na umidade ótima, GC=98\%

- Figura 4.3.2.3. Curva tensão cisalhante e deformação volumétrica versus deslocamento- PEAD/argila- solo na umidade ótima, GC=98\%/ ensaio inundado 
- Figura 4.3.2.4. Comparação entre condição não inundada e inundada- solo na umidade ótima, GC=98\%

- Figura 4.3.2.5. Curvas tensão cisalhante e deformação volumétrica versus deslocamento- PEAD AR/argila- solo na umidade ótima, GC=98\% / ensaio inundado

- Figura 4.3.2.6. Comparação entre condição não inundada e inundada- solo na umidade ótima, GC=98\%

- Figura 4.3.3.1. Curvas tensão cisalhante e deformação volumétrica versus deslocamento- PVC/argila- solo na umidade ótima e GC=85\%/ ensaio inundado

- Figura 4.3.3.2. Verificação do grau de compactação- interface PVC/argilasolo na umidade ótima, ensaio inundado

- Figura 4.3.3.3. Curvas tensão cisalhante e deformação volumétrica versus deslocamento- PEAD lisa/argila- solo na umidade ótima e GC=85\%/ ensaio inundado

- Figura 4.3.3.4. Verificação do grau de compactação- interface PEAD lisa/argila- solo na umidade ótima, ensaio inundado

- Figura 4.3.3.5. Curvas tensão cisalhante e deformação volumétrica versus deslocamento- interface PEAD AR/argila- solo na umidade ótima e GC=85\%/ ensaio inundado

- Figura 4.3.3.6. Verificação do grau de compactação- interface PEAD AR/argila- solo na umidade ótima/ ensaio inundado

- Figura 4.3.3.7. Curvas tensão cisalhante e deformação volumétrica versus deslocamento- interface PVC/argila- solo na umidade ótima e GC=85\%/ ensaio não inundado.

- Figura 4.3.3.8. Verificação do grau de compactação- interface PVC/argilasolo na umidade ótima/ ensaio não inundado_ 
- Figura 4.3.3.9. Curvas tensão cisalhante e deformação volumétrica versus deslocamento- interface PEAD/argila- solo na umidade ótima e GC=85\%/ ensaio não inundado

- Figura 4.3.3.10. Verificação do grau de compactação- interface PEAD/argila- solo na umidade ótima/ ensaio não inundado

- Figura 4.3.4.1. Curvas tensão cisalhante e deformação volumétrica versus

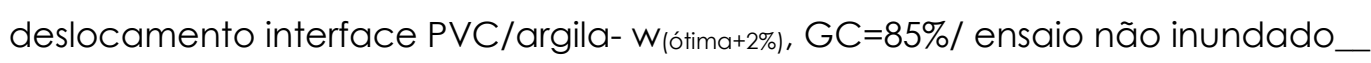

- Figura 4.3.4.2. Influência da umidade inicial- interface PVC/argila, GC=85\%/ ensaio não inundado

- Figura 4.3.4.3. Curva tensão cisalhante e deformação volumétrica versus

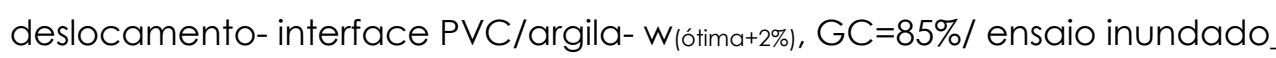

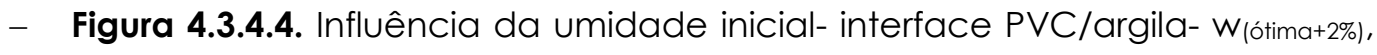
$\mathrm{GC}=85 \% /$ ensaio inundado

- Figura 4.3.4.5. Curvas tensão cisalhante e deformação volumétrica versus

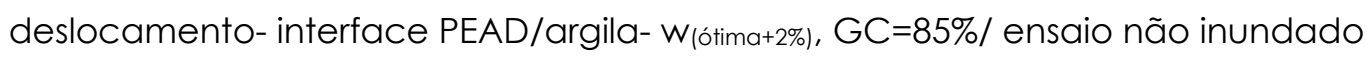

- Figura 4.3.4.6. Influência da umidade inicial- interface PEAD/argila- W(ótima+2\%), $\mathrm{GC}=85 \%$ / ensaio não inundado

- Figura 4.3.4.7. Curvas tensão cisalhante e deformação volumétrica versus

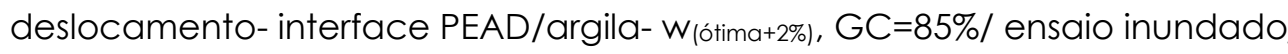

- Figura 4.3.4.8. Influência da umidade inicial- interface PEAD/argila- W(ótima+2\%), GC $=85 \% /$ ensaio inundado

- Figura 4.3.5.1. Resultados dos ensaios de interface argila/PEAD- W(ótima+2\%)/ inundado- Cisalhamento Direto

- Figura 4.3.5.2. Resultados dos ensaios de interface argila/PEAD AR- solo na umidade ótima/ não inundado- Cisalhamento Direto

- Figura 4.3.5.3. Resultados dos ensaios de interface argila/PEAD AR- solo na umidade ótima/ inundado- Cisalhamento Direto 


\section{LISTA DE TABELAS}

- Tabela 2.1.1. Produção diária de resíduos per capita em alguns países e cidades (HEDERRA, 1996 e RUBERG, 1999)

- Tabela 2.3.1.1. Propriedades de degradação dos principais polímeros (JOHN, 1987 \& DEN HOEDT, 1988)

- Tabela 2.3.1.2. Principais tipos de geomembranas (KOERNER, 1994)

- Tabela 2.3.1.3. Vantagens e desvantagens das geomembranas sintéticas mais comumente utilizadas (BAGCHI, 1990)

- Tabela 2.3.2.1. Ensaios de identificação ASTM em geomembranas

- Tabela 2.3.2.2. Ensaios de desempenho ASTM em geomembranas

- Tabela 2.3.2.3. Ensaios de desempenho ASTM em juntas

- Tabela 2.4.3.1. Ângulos de atrito na interface dos liners de Kettleman Hills (FILZ et al., 2001)

- Tabela 2.4.3.2. Comparação das análises de equilíbrio limite (AEL) e análise de elementos finitos (AEF) do aterro de Kettleman Hills (FILZ et al., 2001)

- Tabela 2.4.5.1. Ângulo de atrito para interface solo/ geomembrana (after MARTIN et al.,1984)

- Tabela 2.4.5.2. Ângulo de atrito para interface geomembrana / geotêxtil (after MARTIN et al.,1984)

- Tabela 2.4.5.3. Ângulo de atrito para interface solo / geotêxtil (after MARTIN et al., 1984)

- Tabela 2.2.5.4. Valores dos parâmetros de resistência de diferentes interfaces (BOUAZZA et al., 2002) 
- Tabela 2.4.6.1. Ângulos de atrito residual versus temperatura (PASQUALINI \& SANI, 1993)

- Tabela 2.4.6.2. Ângulos de atrito residual em condições seca e úmida (PASQUALINI \& SANI, 1993)

- Tabela 2.4.6.3. Valores da resistência de cisalhamento, $\tau_{F}$, para materiais argilosos com diferentes densidades e teores de umidade (PASQUALINI \& SANI, 1993)

- Tabela 2.4.6.4 Resumo dos resultados dos ensaios com geomembranas sem envelhecimento (MASADA et al., 1994)

- Tabela 2.4.6.5. Resultados dos ensaios com geomembranas expostas a percolados durante 7 e 30 dias (MASADA et al., 1994)

- Tabela 2.4.6.6. Resumo dos ângulos de atrito entre geomembrana de PEAD lisa e areia para vários tamanhos de caixas de cisalhamento com base (HSIEH et al., 2002)

- Tabela 3.2.1- Métodos utilizados nos ensaios de caracterização de compactação dos solos

- Tabela 4.1.1.1. Propriedades do material granular utilizado nos ensaios 65

- Tabela 4.1.2. Sumário- Valores de ângulos de atrito internos 69

- Tabela 4.1.2.1. Características do solo argiloso utilizado nos ensaios 71

- Tabela 4.1.2.2. Parâmetros de resistência da argila. 76

- Tabela 4.1.3.1. Resultados dos ensaios de tração 77

- Tabela 4.2.2.1. Síntese- Ângulos de atrito de interface entre a areia e diferentes geomembranas

- Tabela 4.2.4.1. Comparação entre os ensaios realizados em condição seca e úmida

- Tabela 4.2.5.1. Comparação entre os ensaios de cisalhamento

- Tabela 4.3.2.1. Sumários dos ensaios de interface- Material moldado com $\mathrm{GC}=98 \%$ 
- Tabela 4.3.3.1. Sumários dos ensaios inundados de interface- Verificação do grau de compactação

- Tabela 4.3.4.1. Verificação do efeito da umidade inicial do material argiloso para amostras moldadas com GC $=85 \%$

- Tabela 4.3.5.1. Comparação entre os ensaios de cisalhamento direto e ring shear 


\section{LISTA DE SIGLAS}

$\begin{array}{ll}\text { ABNT } & \text { Associação Brasileira de Normas Técnicas } \\ \text { ASTM } & \text { American Society for Testing and Materials } \\ \text { AVE } & \text { Acetato de vinil etileno } \\ \text { CCGD } & \text { Caixa de Cisalhamento de Grande Deslocamento } \\ \text { DSC } & \text { Calorimetria diferencial de varredura } \\ \text { GB (GCL) } & \text { Geocomposto bentonítico (Geossynthetic Clay Liner) } \\ \text { GM } & \text { Geomembrana } \\ \text { GT } & \text { Geotêxtil } \\ \text { IEA } & \text { Interpolímero etileno alloy } \\ \text { IR } & \text { Espectroscopia infravermelho } \\ \text { MB } & \text { Método Brasileiro } \\ \text { NBR } & \text { Norma Brasileira } \\ \text { ODSL } & \text { Old Dominion Sanitary Landfill } \\ \text { PA } & \text { Poliamida } \\ \text { PEAD } & \text { Polietileno de elevada densidade } \\ \text { PEBD } & \text { Polietileno de baixa densidade } \\ \text { PEC } & \text { Polietileno clorado } \\ \text { PECS } & \text { Polietileno clorosulfonado } \\ \text { PELMD } & \text { Polietileno linear de média densidade } \\ \text { PET } & \text { Poliéster } \\ \text { PP } & \text { Polipropileno } \\ \text { PVC } & \text { Polivinil clorado } \\ \text { TGA } & \text { Análise termogravimétrica } \\ \text { TMA } & \text { Análise termomecânica } \\ \text { CR } & \text { Compacidade relativa } \\ \text { GC } & \text { Grau de compactação } \\ \end{array}$




\section{LISTA DE SÍMBOLOS}

\begin{tabular}{ll}
\hline & \\
$\tau_{\mathbf{p}}$ & Tensão cisalhante de pico \\
$\tau_{\mathbf{r}}$ & Tensão cisalhante residual \\
$\sigma$ & Tensão normal \\
$\mathbf{T}$ & Torque \\
$\delta_{\mathbf{p}}$ & Ângulo de atrito de pico na interface solo/geomembrana \\
$\delta_{\mathbf{r}}$ & Ângulo de atrito residual na interface solo/geomembrana \\
$\mathbf{e}$ & Índice de vazios \\
$\gamma_{\mathbf{d}}$ & Peso específico seco \\
$\mathbf{w}$ ótima & Umidade ótima \\
$\mathbf{k}$ & Permeabilidade \\
$\phi$ & Ângulo de atrito interno \\
$\mathbf{C}$ & Coesão \\
$\Delta$ & Deslocamento linear médio \\
$\rho$ & Massa específica
\end{tabular}




\section{RESUMO}

REBELO, K.M.W. (2003)- Resistência de Interface entre Geomembranas e Solos através do Ensaio de Ring Shear (mestrado)- Escola de Engenharia de São Carlos, Universidade de São Paulo- São Carlos.

Investiga-se neste trabalho a resistência ao cisalhamento em interfaces geomembrana-solo, utilizadas nos sistemas de impermeabilização de aterros e lagoas de efluentes. Foram realizados ensaios de ring shear envolvendo solos arenosos e argilosos, em condição seca e inundada. Os ensaios foram realizados utilizando uma areia de granulometria grossa a média e um solo argiloso proveniente do aterro sanitário de Piracicaba- SP. Neste trabalho foram utilizadas geomembranas de polivinil clorado, polietileno linear de média densidade e polietileno de alta densidade, com diferentes níveis de rugosidade. Os resultados mostraram que a resistência ao cisalhamento depende das características das geomembranas utilizadas, como flexibilidade e rigidez, além de outras. Conforme esperado, observou-se que as geomembranas texturizadas apresentaram maiores valores de ângulo de atrito do que as geomembranas lisas; enquanto as geomembranas flexíveis mostraram maiores valores de ângulo de atrito que as rígidas. Este comportamento foi verificado em ambos os tipos de interface. Verificou-se também que o efeito da compacidade dos materiais granulares e da saturação dos materiais mostrou-se pouco acentuado na resistência de interface areia/geomembrana. Nos ensaios de interface com solo argiloso foi verificado que a inundação influencia na resistência de interface, fornecendo menores valores de ângulos de atrito do que nos ensaios não inundados. Além deste aspecto, verificou-se que a resistência de interface em ensaios não inundados depende da umidade de compactação do solo argiloso. Este fato não foi verificado nos ensaios inundados.

Palavras-chave: geomembrana, areia, argila, resistência ao cisalhamento de interface. 


\section{ABSTRACT}

REBELO, K.M.W. (2003)- Interface strength between geomembranes and soils by ring shear test- MSc. Dissertation- Escola de Engenharia de São Carlos, Universidade de São Paulo- São Carlos.

This paper deals with the shear strength in the geomembrane-soil interfaces used in landfill and waste pond liners. Modified ring shear tests were carried out using sandy and clayey soils, in dry and saturated conditions. The tests were performed using a coarse to medium graded sand and a clayey soil from a sanitary landfill in Piracicaba - SP. In this work, polyvinyl chloride geomembranes, medium density linear polyethylene and high-density polyethylene, with different roughness levels, were used. The test results showed that the shear strength depends on several geomembrane characteristics, such as roughness and stiffness. As it was expected, texturized geomembranes showed higher friction angle values than smooth geomembranes; flexible geomembranes showed higher friction angle values than the stiff ones. Such behavior was verified in both interface types. Also, it was verified that the sand compaction and the material saturation have little influence on the sandgeomembrane interface shear strength. The interface shear strength tests, performed with a clayey soil, showed that the wetting condition affects the interface shear strength. Friction angle for wetted samples were smaller than those for non-wetted samples. In addition, it has been verified that the interface shear strength in non-wetted tests depends on the moisture content of the clayey soil. This fact has not been verified in the wetted tests.

Keywords: geomembrane, sand, clay, interface shear strength. 


\section{INTRODUÇÃO}

Uma característica inerente a toda atividade humana é a produção de resíduos, dos mais variados tipos e naturezas. A despeito da crescente conscientização da sociedade e das técnicas de gerenciamento que buscam reduzir, reaproveitar e reciclar os resíduos produzidos, sempre restam resíduos que necessitam serem dispostos no meio físico.

Dentre as alternativas para disposição final destes resíduos, destaca-se a disposição em aterros sanitários e industriais, e em lagoas de efluentes. Estas alternativas apóiam-se em critérios de engenharia e normas operacionais específicas, cuja finalidade é permitir o confinamento seguro dos resíduos e efluentes no solo, contribuindo para minimizar os impactos ambientais.

Um componente desses sistemas é a barreira impermeável, também denominada de liner, que é constituída de elementos com baixa condutividade hidráulica. Pode ser aplicada no sistema de cobertura, cuja função principal é proteger as células de resíduos e diminuir a taxa de infiltração para o interior do maciço, e no sistema de impermeabilização basal, que se destina a reter os líquidos percolados de forma a que não atinjam o solo subjacente e as águas subterrâneas e superficiais. As barreiras impermeáveis podem ser constituídas por solos naturais de baixa condutividade hidráulica, por solos compactados e materiais sintéticos, como geomembranas.

Uma forma de compor barreiras impermeáveis consiste na combinação de solos argilosos compactados e materiais sintéticos segundo diferentes combinações, formando barreiras compostas. No entanto, uma questão crucial no projeto e construção dessas barreiras reside na possibilidade de deslizamento nas interfaces, devido às diferentes características resistentes dos materiais em contato. 
Além das rupturas de aterros serem atribuídas às baixas resistências ao cisalhamento nas interfaces das barreiras impermeáveis, deve-se atentar ainda para o mecanismo da ruptura progressiva que ocorre durante 0 lançamento dos resíduos.

Vários equipamentos de cisalhamento têm sido utilizados para investigar os mecanismos que atuam no comportamento de cisalhamento nas interfaces de liners. Citam-se os ensaios de cisalhamento direto, de arrancamento, de plano inclinado, de mesa vibratória e o de "ring shear". Dentre estes, destacase o ensaio de ring shear, utilizado no presente trabalho. Apesar de ser um método pouco empregado, constitui-se um dos ensaios mais apropriados por permitir a continuidade dos deslocamentos até que a condição residual seja atingida.

\subsection{OBJETIVO}

Este trabalho teve como objetivo principal investigar 0 comportamento da resistência ao cisalhamento de interfaces envolvendo geomembranas e diferentes materiais, como areias e solos argilosos, utilizados em sistemas de barreiras impermeabilizantes de aterros.

Nesta avaliação foram empregados ensaios de cisalhamento em anel ("ring shear tests") com dimensões adequadas ao objetivo pretendido e geomembranas de PVC (polivinil clorado), PELMD (polietileno linear de média densidade) e PEAD (polietileno de alta densidade), estas com diferentes níveis de rugosidade. Para as amostras foram empregados uma areia de laboratório e um solo argiloso do estado de São Paulo, com o intuito de comparar os resultados obtidos com os dados existentes na literatura, e o de oferecer alguns parâmetros preliminares de projeto. Quanto aos ensaios, foram simuladas diferentes condições com o intuito de verificar os fatores que interferem no comportamento de interfaces, e as condições mais críticas. 


\subsection{ESTRUTURA DA DISSERTAÇÃO}

A dissertação aqui apresentada é dividida da seguinte forma:

- Capítulo 1- Introdução: Onde são abordados uma pequena introdução e objetivo do trabalho realizado;

- Capítulo 2- Revisão Bibliográfica: No qual são abordados os principais conceitos relacionados a aterros sanitários e geomembranas; a problemática da disposição de resíduos; os tipos de equipamentos empregados e os fatores que influenciam na resistência ao cisalhamento em interfaces;

- Capítulo 3- Materiais e Métodos: Neste capítulo são descritos os solos e geossintéticos utilizados, e os tipos de ensaios e/ou técnicas realizados;

- Capítulo 4- Análise de Resultados: Onde são apresentados e discutidos os resultados dos ensaios de cisalhamento em interfaces. Também são apresentados os resultados dos ensaios de caracterização de solos e de geossintéticos;

- Capítulo 5- Conclusões: Neste capítulo são sintetizadas as principais conclusões da dissertação;

- Apêndice- São apresentados os resultados complementares que pertencem ao programa experimental desta dissertação;

- Anexo- Neste item são apresentados alguns resultados de caracterização de solos, que não constituem objeto principal da dissertação, mas são indispensáveis à mesma. 


\section{REVISÃO BIBLIOGRÁFICA}

\subsection{A PROBLEMÁTICA DA DISPOSIÇÃO DE RESÍDUOS}

Toda atividade humana gera resíduos dos mais variados tipos e naturezas. Dentre estes, encontram-se os resíduos sólidos que, de acordo com a Associação Brasileira de Normas Técnicas (ABNT) na sua forma NBR10.004/1987, são conceituados como "resíduos sólidos compreendem os resíduos nos estados sólido e semi-sólido que resultam da atividade da comunidade de origem: industrial, doméstica, hospitalar, comercial, de serviços, de varrição ou agrícola".

Ainda de acordo com a NBR-10.004/1987, existem cinco critérios de periculosidade para os resíduos: inflamabilidade; corrosividade; reatividade; toxicidade e patogenicidade. Com base nestes critérios, classifica os resíduos em três formas distintas apresentadas abaixo:

A. Classe I- perigosos- Em função de suas propriedades físicas, químicas ou infecto-contagiosas, podem apresentar riscos à saúde pública ou ao meio ambiente, constituindo os resíduos inflamáveis, corrosivos, reativos, tóxicos ou patogênicos;

B. Classe II- não inertes- Não se enquadram nas classes I e II, e que podem ser combustíveis, biodegradáveis ou solúveis em água, como os papéis, papelão, matéria vegetal, etc.;

C. Classe III- inertes- Não tem nenhum de seus constituintes solubilizados a concentrações superiores aos padrões de potabilidade de água, excetuando-se os padrões de aspecto, cor, turbidez e sabor. Compreendem tijolos, vidros, borrachas e alguns plásticos. 
De acordo com Mauro (1997), os principais impactos da disposição inadequada dos resíduos no meio físico são: degradação dos recursos hídricos; polvição e contaminação do aqüífero e lençol freático; redução da fauna e flora do solo e das águas superficiais; permanência de produtos não biodegradáveis no meio ambiente; eutrofização no solo e nas águas; aumento de animais que podem contribuir como vetores de doenças; polvição atmosférica e comprometimento dos aspectos visuais/estéticos.

Hederra (1996) e Ruberg (1999) relatam em seus trabalhos a produção diária de resíduos per capita em alguns países e cidades, apresentado na Tabela 2.1.1.

Tabela 2.1.1. Produção Diária de Resíduos per capita em alguns Países e Cidades.

\begin{tabular}{|c|c|c|c|}
\hline País /Cidade & $\begin{array}{c}\text { Produção } \\
\text { (kg/hab./dia) }\end{array}$ & País/Cidade & $\begin{array}{l}\text { Produção } \\
\text { (kg/hab./dia) }\end{array}$ \\
\hline Canadá & 1,90 & João Pessoa & 0,70 \\
\hline EUA & 1,50 & Belo Horizonte & 0,68 \\
\hline Holanda & 1,30 & San Salvador & 0,68 \\
\hline Japão & 1,00 & Vitória & 0,66 \\
\hline Europa/México -DF & 0,90 & Curitiba & 0,66 \\
\hline Rio de Janeiro & 0,90 & Petropólis & 0,53 \\
\hline Maceió & 0,89 & Tegucigalpa & 0,52 \\
\hline São Paulo & 0,88 & Lima & 0,50 \\
\hline Buenos Aires & 0,88 & Novo Hamburgo & 0,40 \\
\hline San José & 0,74 & Índia & 0,40 \\
\hline
\end{tabular}

Fonte: Hederra (1996) e Ruberg (1999)

O que se tem observado é que quanto maior o grau de desenvolvimento do país e de um município, maior a taxa de produção diária de resíduos sólidos per capita. Isto se deve às maiores atividades econômicas e aos hábitos de consumo decorrentes.

Segundo o Manual de Gerenciamento Integrado do Lixo MunicipalIPT (1995), a disposição final de lixo nos municípios brasileiros divide-se da seguinte forma: 
- $\quad 76 \%$ em lixões (a céu aberto);

- $13 \%$ em aterros controlados;

- $10 \%$ em aterros sanitários;

- $\quad 0,9 \%$ em usinas de compostagem;

- $\quad 0,1 \%$ em usinas de incineração.

Os dados indicam que, naquela época, grande parte dos municípios brasileira utilizava ainda vazadouros e lixões para disposição final do lixo. Esta situação tem-se modificado nos últimos anos graças a uma maior preocupação da sociedade e dos órgãos que cuidam da preservação ambiental. Políticas alternativas têm sido incentivadas, como a recuperação e a reciclagem dos resíduos, e técnicas de disposição seguras e eficientes do ponto de vista sanitário e ambiental. Neste sentido, a disposição em aterros tem-se destacado em relação a outras técnicas porque, além de cumprir os requisitos mínimos sanitários e ambientais, são simples e baratos na parte de execução, e pelo fato de que em qualquer técnica de tratamento e redução, sempre restam resíduos que necessitam serem dispostos.

\subsection{ATERROS SANITÁRIOS}

\subsubsection{Aspectos Gerais}

A NBR 8419/87 define aterro sanitário como "o método de disposição de resíduos sólidos no solo, sem provocar prejuízos ou ameaças à saúde e à segurança, utilizando-se de princípios de engenharia, de tal modo, a confinar o lixo no menor volume possível, cobrindo-o com uma camada de terra, ao fim do trabalho de cada dia, ou mais freqüentemente, conforme o necessário". 


\subsubsection{Elementos estruturais básicos de um aterro}

\section{Tratamento da fundação}

Gartung (1996) relata que a geotecnia corresponde um elemento estrutural muito importante, pois os locais de implantação dos aterros são definidos em função das características geotécnicas de uma determinada região. Caso as características geotécnicas das camadas dos subsolos dos aterros e de suas adjacências sejam insatisfatórias, é necessário o tratamento da fundação.

Dentre as alternativas para o tratamento da fundação, Carvalho (1999) cita a remoção e substituição de solos moles com baixa capacidade de carga e/ou tratamento de trincas e fraturas em rochas do subsolo e de suas encostas adjacentes. Contudo, cabe aqui ressaltar que este tipo de tratamento não é muito comum, uma vez que dificilmente serão implantados aterros em locais que apresentem tais características.

Tiveron et al. (1995) definem ainda como tratamento da fundação, a captação e a drenagem de nascentes e cursos d' águas, e a impermeabilização do terreno da fundação, componente este, tratado à parte.

\section{$\underline{\text { Sistemas de drenagem de gases e de líquidos percolados }}$}

De acordo com Carvalho (1999), o sistema de drenagem de líquidos percolados deve coletar e conduzir os líquidos percolados através de drenos internos, reduzindo as pressões atuantes dos líquidos na massa do resíduo e minimizando o potencial de migração do mesmo no solo. Este sistema poderá ser projetado através de drenos de brita com tubo perfurado, direcionando os percolados até o local de acumulação, de onde serão enviados a um tratamento adequado por gravidade, bombeamento direto ou em carros-tanque. A sua concepção depende da alternativa de tratamento adotado para o aterro sanitário, podendo inclusive estar associada ao sistema de drenagem de gases. 
O sistema de drenagem de gases tem a função de drenar os gases provenientes da decomposição da matéria orgânica resultante do processo de digestão. Apresenta como finalidade, evitar a migração de gases através dos meios porosos que constituem o subsolo, uma vez que concentrações de $\mathrm{CH}_{4}$ (metano) entre cinco e $15 \%$ são explosivas. Estes drenos atravessam todo o aterro no sentido vertical, desde a cobertura superficial até o fundo do aterro (LEITE, 1991; TIVERON et al., 1995).

Dentro do sistema de drenagem de líquidos percolados, destaca-se também o sistema de drenagem da fundação para a coleta de águas naturais e dos líquidos percolados. O processo é realizado através de drenos internos de brita com tubos perfurados que são conduzidos até o local de acumulação, de onde serão enviados a um tratamento adequado.

Os drenos horizontais facilitam a drenagem da massa do resíduo, sendo implantados junto ao topo da camada de solo da célula subjacente a partir da escavação de valas que a interligam aos drenos verticais.

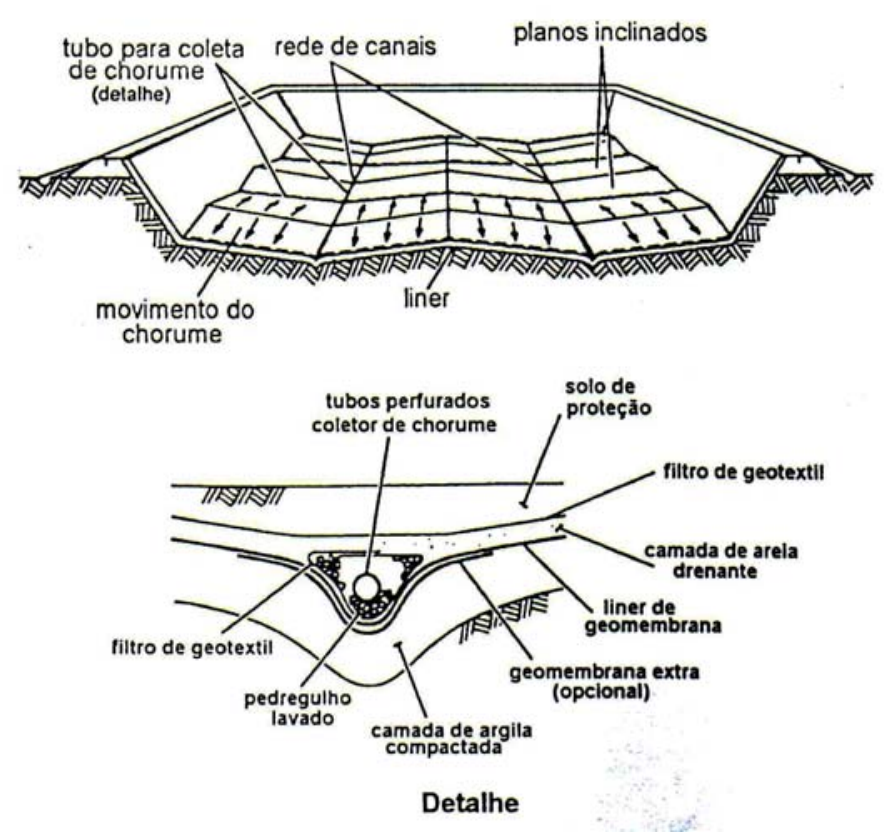

Figura 2.2.2.1 Sistema de drenagem de líquidos percolados (TCHOBANOGLOUS et al. apud CARVALHO, 1999). 


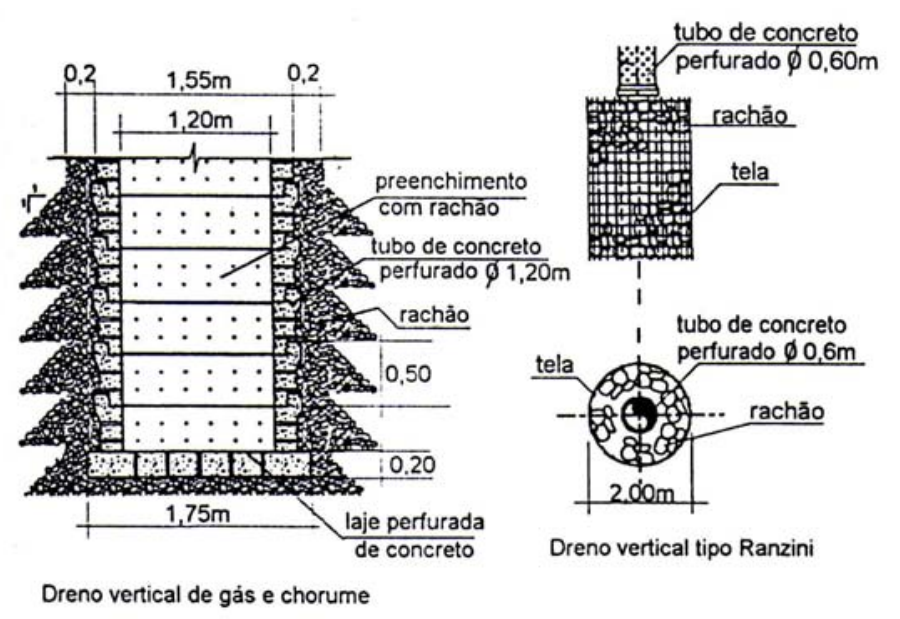

Figura 2.2.2.2. Drenos verticais dos aterros sanitários (TIVERON et al., 1995).

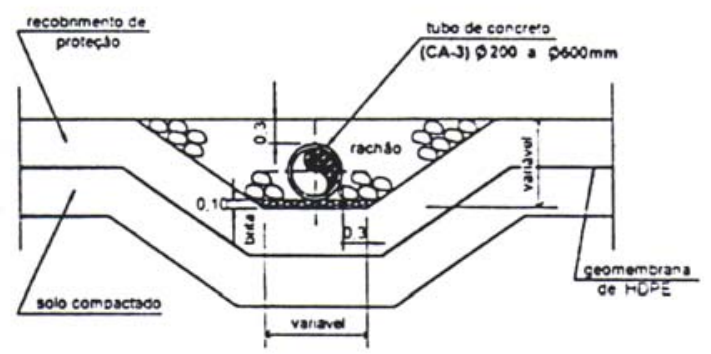

DRENO DE FUNOAÇAO

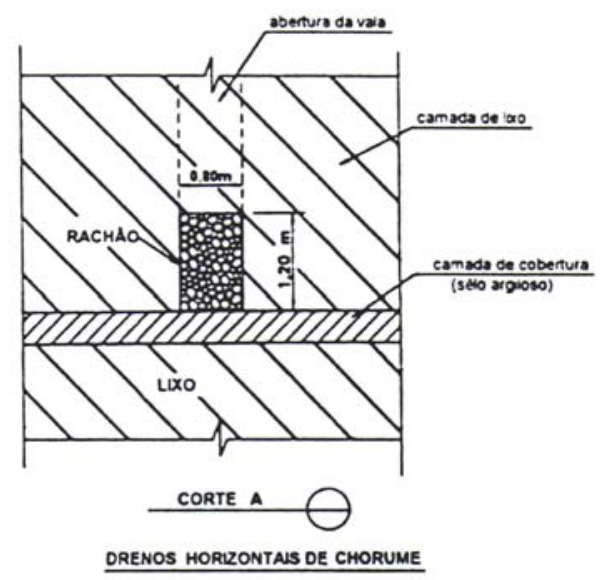

Figura 2.2.2.3. Drenos de fundação e drenos horizontais (TIVERON et al., 1995).

\section{Sistema de drenagem de águas pluviais}

De acordo com Leite (1991), o objetivo deste sistema é interceptar e desviar o escoamento superficial das águas pluviais para fora do aterro, diminuindo desta forma o volume de líquidos percolados. Nos aterros, em geral, o sistema de drenagem de águas pluviais é constituído por estruturas drenantes de canaletas associadas a escadas d' águas e tubos de concreto. Deve-se observar formas de conduzir os líquidos para um único local, distinto do local dos líquidos percolados pelo aterro, que necessitam de tratamento antes de serem lançados na drenagem natural. 

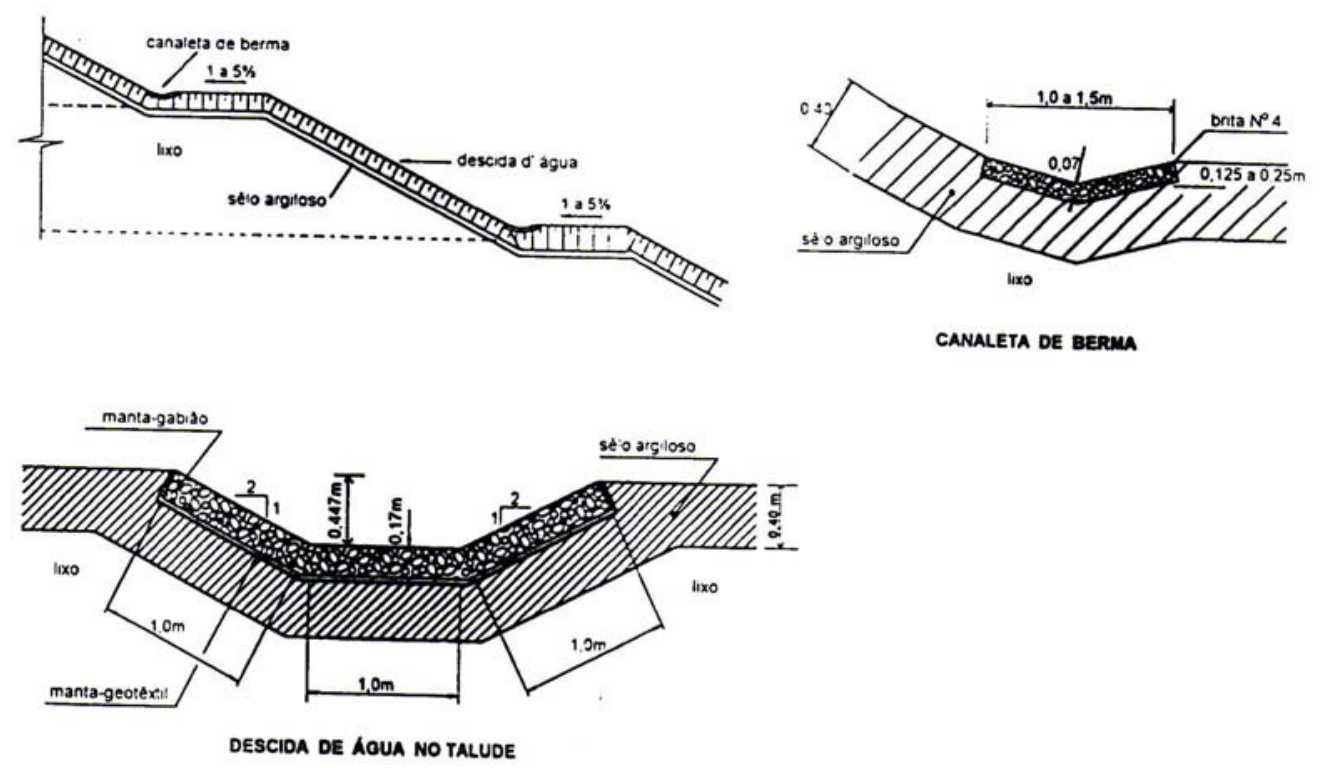

Figura 2.2.2.4. Drenos de águas superficiais (TIVERON et al., 1995).

\section{Sistema de impermeabilização}

As barreiras impermeáveis, também denominadas de liner, consistem em dispositivos utilizados quando se deseja reter ao máximo possível os líquidos percolados, de forma que não atinjam as águas e o solo natural (CARVALHO, 1999). Podem ser utilizadas como cobertura de aterros e na impermeabilização da base.

Lengen \& Siebken (1996) relatam que os sistemas de impermeabilização antigos consistiam apenas de solo local compactado. Hoje, os sistemas de impermeabilização consistem em revestimentos com geossintéticos e/ou argilas compactadas.

As barreiras impermeáveis podem ser naturais, sintéticas ou argila compactada. A escolha do tipo é influenciada pelo uso a que se destina, pelo meio ambiente físico, pela química da solução percoladora e da água subterrânea, pela vida útil do projeto, taxa de infiltração e restrições físicas.

As barreiras naturais compreendem os solos argilosos naturais de baixa condutividade hidráulica, com k variando entre $10^{-6} \mathrm{a} \quad 10^{-7} \mathrm{~cm} / \mathrm{s}$ (DANIEL, 1993). De acordo com Carvalho (1999), a espessura mínima das barreiras naturais é de um metro, e na grande maioria dos casos, são 
utilizadas como complemento, mas podem ser apresentadas em sua forma simples.

Por sua vez, as barreiras de argila compactada são constituídas essencialmente por solos compactados, podendo conter bentonita ou materiais sintéticos. Este tipo de material apresenta condutividade hidráulica adequada, e são resistentes em longo prazo com relação às influências químicas dos percolados e podem apresentar alto potencial de retenção do contaminante (DANIEL, 1993).

As barreiras sintéticas são compostas de materiais poliméricos que apresentam condutividade hidráulica extremamente baixa, elevadas resistências química e física, sendo utilizadas no revestimento de aterros.

Segundo Bouazza et al. (2002), vários tipos de barreiras impermeáveis são utilizados para contenção de resíduos, e estas podem variar significantemente em complexidade. Geralmente as geomembranas não são utilizadas sozinhas em função dos possíveis defeitos que podem apresentar, e que podem resultar em grandes fluxos de percolação.

Desta forma, podem ser constituídas de revestimentos simples, quando apresentam um único material, ou compostas, quando são constituídas de uma combinação de diferentes materiais. E ainda podem ser duplas, quando apresentam uma camada dupla de revestimento, sendo mais utilizadas para disposição de rejeitos perigosos.

De acordo com August et al. apud Gartung (1996), as barreiras compostas constituem os impermeabilizantes mais eficientes contra a migração de componentes prejudiciais devido à lixiviação. Bouazza et al. (2002) também afirmam que o sistema de barreira composta corresponde ao mais utilizado na impermeabilização de aterros. A sua principal vantagem é que apresenta baixa permeabilidade $\left(k>10^{-7} \mathrm{~m} / \mathrm{s}\right)$.

Os sistemas compostos apresentam a seguinte composição: camada de argila compactada; geomembrana e camada de proteção. Esta camada de proteção é constituída de uma camada drenante de pedregulhos grossos ou pedra britada de aproximadamente $32 \mathrm{~mm}$ de diâmetro, cuja função é prevenir pressões de lixiviação de resíduos sobre as camadas de impermeabilização; e da camada de proteção propriamente 
dita, para evitar danos mecânicos na geomembrana, que pode ser realizada com produtos geossintéticos como geotêxteis.

Segundo Gartung (1996), o sistema de cobertura tem a função de proteger a superfície das células de resíduos, minimizando impactos ao meio ambiente, visando à eliminação da proliferação de vetores, à diminuição da taxa de formação de percolados, à redução da exalação de odores e formação de poeiras a partir dos resíduos, impedir a catação, emissão descontrolada de gases e permitir o tráfego de veículos coletores sobre o aterro.

Sharma \& Lewis (1994) enfatizam que esse sistema é diferente do sistema de impermeabilização da base do aterro, necessitando de resistência química inferior à requerida para este último. Entretanto, existem preocupações quanto a sua durabilidade e exposição, devendo ser resistente a processos erosivos e adequado à futura utilização da área. $\mathrm{Na}$ Figura 2.2.2.5 são apresentadas algumas configurações típicas para cobertura.

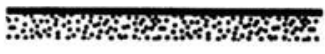

Liner de geomembrana simples

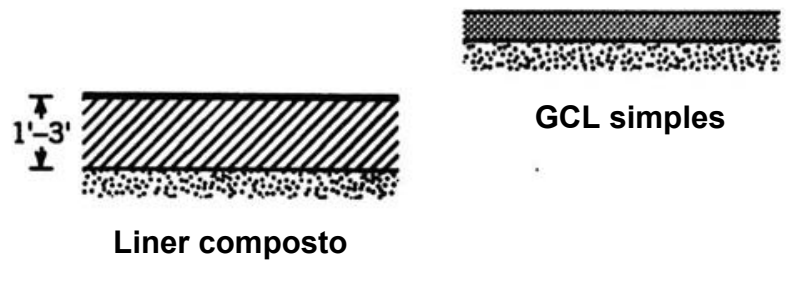

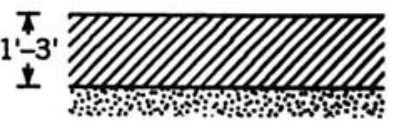

Liner de argila simples

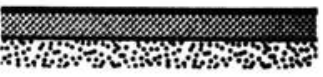

Liner composto com GCL

Figura 2.2.2.5. Configuração do sistema de cobertura (SHARMA \& LEWIS, 1994).

As possíveis formas de barreiras impermeabilizantes basal são apresentadas por Sharma \& Lewis (1994) na Figura 2.2.4.6. 

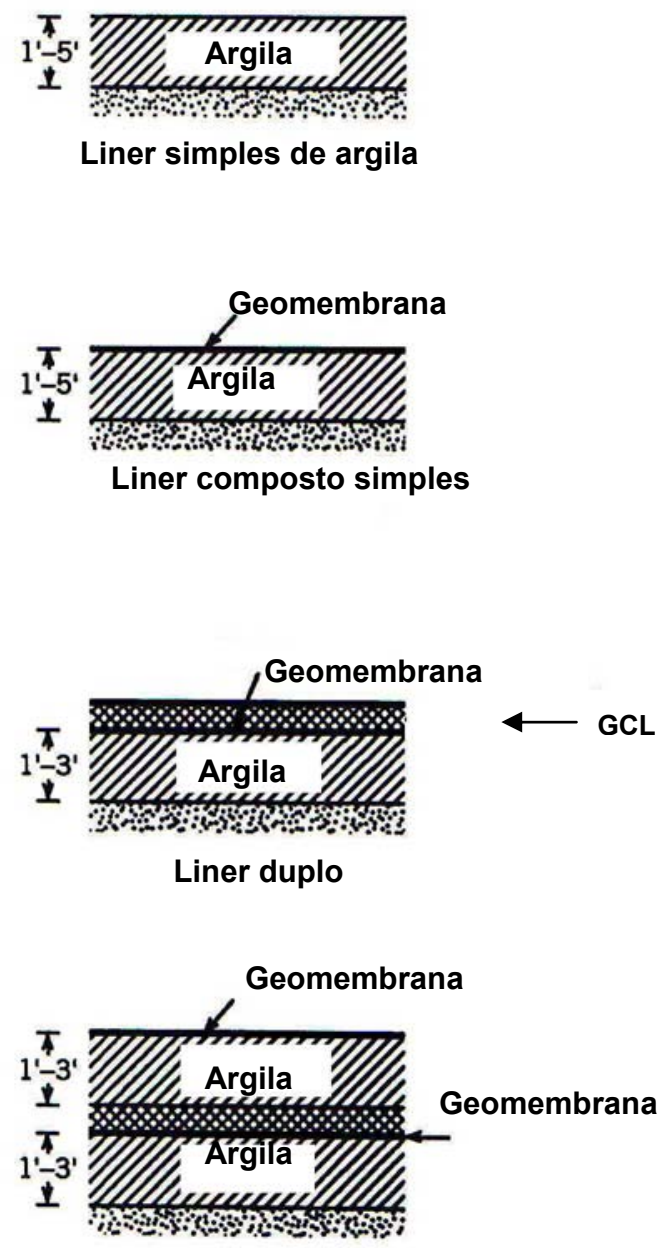

Liner composto duplo
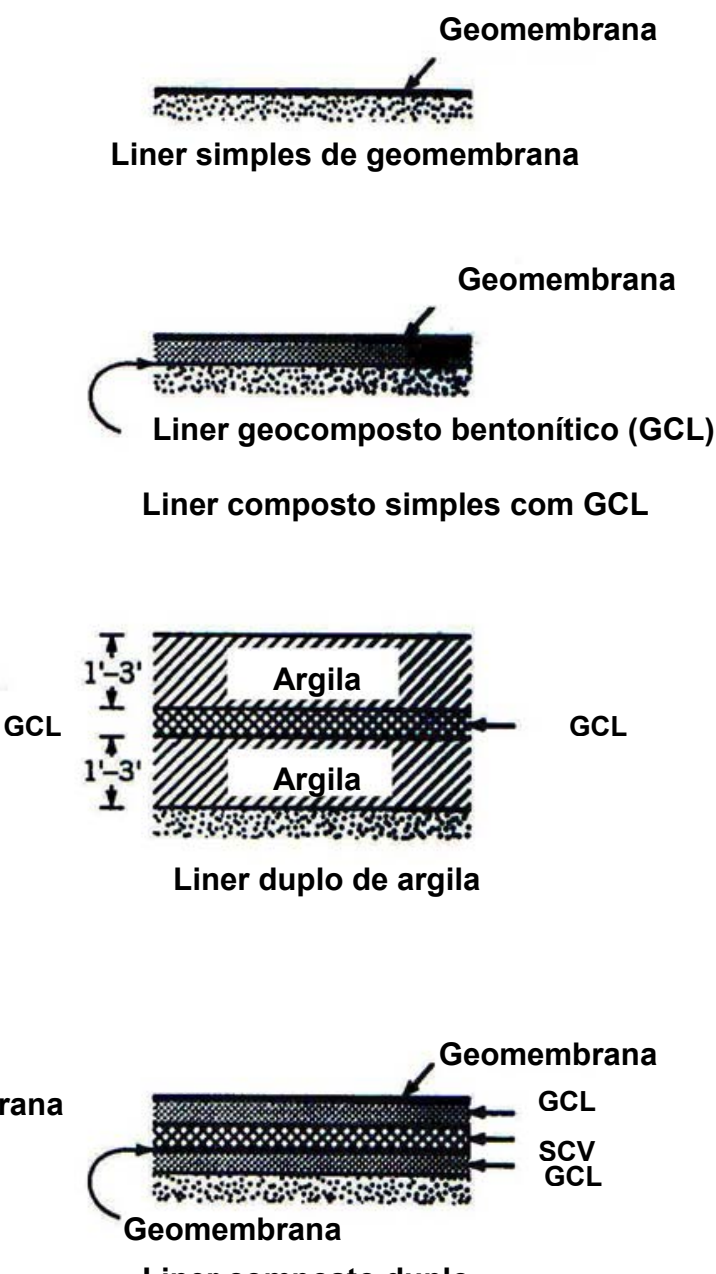

Liner composto duplo

Figura 2.2.2.6. Configuração do sistema de liners (SHARMA \& LEWIS, 1994).

Segundo Van Impe \& Areias et al. apud Carvalho (1999), os sistemas de impermeabilização de base de aterros nos EUA são definidos independentemente das condições do terreno natural, enquanto que em alguns países europeus estas características são observadas. Estes autores ainda defendem que apesar do nível mínimo de proteção, os sistemas de impermeabilização não são suficientes para assegurar o mínimo impacto ambiental em alguns casos; e deve-se atentar ainda para os padrões de funcionamento e qualidade de execução dos liners. 


\subsection{GEOMEMBRANAS}

\subsubsection{Aspectos gerais}

As geomembranas são materiais poliméricos, de baixa condutividade hidráulica e de pequenas espessuras empregadas no revestimento ou cobertura de depósitos de efluentes ou resíduos sólidos. Ao contrário dos geotêxteis, que podem funcionar como elemento de separação, de reforço, de filtração e de drenagem, as geomembranas possuem como função primária a de prover uma camada impermeável para controlar a percolação e o fluxo de líquidos, e em alguns casos, de gases. Apesar de suas funções limitadas, surgiram como alternativa a materiais tradicionais, tendo seu uso aumentado nos últimos vinte anos. Tal aumento deve-se à regulamentação de atividades ambientais e à maior distribuição de dados e informações sobre as propriedades e eficácia das geomembranas.

A introdução da geomembrana no mercado tornou-se possível com a produção do PVC (polivinil clorado) no início de 1930, sendo apenas utilizado no início do ano de 1940 com aplicações na agricultura, na impermeabilização de canais, e somente utilizado como contenção de resíduos a partir de 1965 (STAFF apud LENGEN \& SIEBKEN, 1996). Em contrapartida, as geomembranas de polietileno (PE) tiveram sua produção no ano de 1943 na Alemanha, e o seu uso como geomembrana não foi desenvolvido até os anos 60 (POHL \& WESTON, 1992).

Atualmente, as geomembranas são mundialmente conhecidas em face de sua disponibilidade e aplicabilidade. Por apresentarem baixa permeabilidade, da ordem de $10^{-11}$ a $10^{-13} \mathrm{~cm} / \mathrm{s}$, menor do que a permeabilidade de materiais concorrentes (bentonita- $10^{-8} \mathrm{~cm} / \mathrm{s}$ ), funcionam como barreiras impermeáveis, e possuem grande importância na área de engenharia ambiental.

Segundo Koerner (1994), as geomembranas são utilizadas na área ambiental para as seguintes aplicações: barreiras impermeáveis para reservatórios; coberturas para reservatórios; barreiras impermeáveis para tanques de armazenamento e sistemas de drenagem; barreiras 
separadoras de paredes; barreiras impermeáveis de aterro e coberturas para aterros.

A maior parte das geomembranas é composta de materiais poliméricos do tipo termoplásticos, termofixos e combinações destes tipos. Os polímeros consistem em compostos de elevado peso molecular obtidos por combinações ou reações químicas de moléculas de baixo peso molecular, denominadas monômeros.

John (1987) e Den Hoedt (1988) relatam as propriedades de alguns polímeros, que se encontram na Tabela 2.3.1.1.

Tabela 2.3.1.1. Propriedades de degradação de alguns polímeros.

\begin{tabular}{lcccc}
\hline & \multicolumn{4}{c}{ Polímero } \\
\cline { 2 - 5 } Propriedade & PET & PP & PEAD & PA \\
\hline Foto - degradação & 3 & $3^{*}$ a l $^{* *}$ & $3^{*}$ a $1^{* *}$ & 2 \\
Termo - oxidação & 3 & 1 & 1 & 2 \\
Hidrólise & 1 & 2 & 2 & 1 \\
Degradação biológica & 3 & 3 & 3 & 3 \\
Degradação química a álcalis & 1 & 2 a 3 & 3 & 2 \\
Degradação química a ácidos & 2 & 3 & 3 & 1 \\
Fluência & 3 & 2 & 2 & 2 \\
\hline
\end{tabular}

Fonte: John (1987) e Den Hoedt (1988) * com tratamento (por ex. negro de fumo) ** sem tratamento

Resistência elevada (3) , resistência média (2), resistência baixa (1).

Segundo Palmeira (1993), os polímeros termoplásticos são aqueles que podem sofrer repetidos estágios de aquecimento e resfriamento, sem que alterem suas características básicas. Os polímeros termofixos, por sua vez, são aqueles que não podem sofrer repetições de estágios de aquecimento e resfriamento, pois qualquer aumento adicional após a formação do polímero provocará a sua degradação.

Os aditivos podem ser incorporados no processo de fabricação dos geossintéticos visando a melhoria de suas propriedades, abaixar o custo, 
facilitar o processamento, colorir, e outras características. Na Tabela 2.3.1.2, apresentam-se os tipos de polímeros propostos por Koerner (1994).

Tabela 2.3.1.2. Principais tipos de geomembranas.

\begin{tabular}{l}
\hline POLÍMEROS TERMOPLÁSTICOS \\
\hline Polivinil clorado - PVC \\
Polietileno - PE (PEDMB, PEBD, PEDBL, PEMD, PEAD, referidos a \\
muito baixa, baixa, baixa linear, média e alta densidade) \\
Polietileno clorado - PEC \\
Poliamida - PA \\
Interpolímero etileno alloy - IEA ou EIA
\end{tabular}

\section{POLÍMEROS TERMOFIXOS}

Butyl - borracha de butila

Monômero de dieno - propileno- etileno - MDPE

Neoprene - policloropreno

Polímero de propileno etileno - PPE

Acetato de vinil etileno - AVE

\section{COMBINAÇÕES}

PVC - policloreto de vinila combinado

PE - MDPE

PVC - acetato de vinil etileno

PECS - polietileno clorosulfonado ou Hypalon

Ligações Cruzadas PEC

Fonte: KOERNER (1994)

Bagchi (1994) apresenta na Tabela 2.3.1.3 as vantagens e desvantagens das geomembranas sintéticas mais comumente utilizadas. 
Tabela 2.3.1.3. Vantagens e desvantagens das geomembranas sintéticas mais comumente utilizadas.

\begin{tabular}{|c|c|}
\hline GEOMEMBRANA & VANTAGENS / DESVANTAGENS \\
\hline Polietileno clorado (PEC) & $\begin{array}{l}\text { Boa resistência aos raios UV e elementos } \\
\text { climáticos; bom desempenho para baixas } \\
\text { temperaturas; boas características de } \\
\text { esistência; facilidade para emendas; } \\
\text { pobre resistência para químicos, ácidos e } \\
\text { óleos; pobre qualidade na emenda. }\end{array}$ \\
\hline Polietileno clorosulfonado (PECS) & $\begin{array}{l}\text { Boa resistência aos raios UV e elementos } \\
\text { climáticos; bom desempenho para baixas } \\
\text { temperaturas; baixas características de } \\
\text { esistência; problemas durante emendas; } \\
\text { boa resistência para químicos, ácidos e } \\
\text { óleos; boa resistência para bactérias. }\end{array}$ \\
\hline $\begin{array}{l}\text { Monômero de dieno - } \\
\text { propileno-etileno (MDPE) }\end{array}$ & $\begin{array}{l}\text { Boa resistência aos raios UV e elementos } \\
\text { climáticos; bom desempenho para baixas } \\
\text { temperaturas; elevadas características de } \\
\text { esistência; baixa adsorção de água; } \\
\text { pobre resistência para químicos, ácidos e } \\
\text { óleos; pobre qualidade na emenda. }\end{array}$ \\
\hline $\begin{array}{l}\text { Polietileno de baixa densidade e } \\
\text { de alta densidade (PEBD e } \\
\text { PEAD) }\end{array}$ & $\begin{array}{l}\text { Boa resistência para a maior parte de } \\
\text { químicos; boas características de emenda } \\
\text { e resistência; bom desempenho para } \\
\text { baixas temperaturas; pobre resistência ao } \\
\text { suncionamento. }\end{array}$ \\
\hline Polivinil clorado (PVC) & $\begin{array}{l}\text { Pobre resistência aos raios UV e elementos } \\
\text { climáticos; bom desempenho para baixas } \\
\text { e elevadas temperaturas; elevadas } \\
\text { saracterísticas de resistência; facilidade } \\
\text { para emenda; boa trabalhabilidade. }\end{array}$ \\
\hline
\end{tabular}




\subsubsection{Propriedades Gerais}

Uma vez que a permeabilidade dos diferentes tipos de geomembranas é muito semelhante, a questão preponderante é a manutenção de sua integridade físico-química. Portanto, na escolha da geomembrana adequada a ser utilizada em aterros, é necessário considerar suas propriedades mecânicas, físicas e químicas.

Tais propriedades são verificadas através de ensaios de laboratório regulamentados por diversas entidades como a American Society for Testing and Materials (ASTM) e a Associação Brasileira de Normas Técnicas (ABNT), visando à identificação e o desempenho das geomembranas. Desta forma, os ensaios podem ser divididos em ensaios de identificação e ensaios de desempenho.

\section{Ensaios de identificação}

O objetivo destes ensaios é verificar se os produtos estão de acordo com as especificações exigidas. Dentre as diversas normas são listadas, na Tabela 2.3.2.1, as da ASTM aplicáveis ao propósito de identificação.

\section{Ensaios de Desempenho}

Os ensaios de desempenho têm como objetivo demonstrar a capacidade da geomembrana exercer sua função impermeabilizante, levando-se em conta as tensões "in situ" e as condições ambientais. Estes ensaios podem ser realizados no corpo principal da geomembrana ou nas emendas construtivas. As normas da ASTM aplicáveis aos ensaios de desempenho são listadas nas Tabelas 2.3.2.2 e 2.3.2.3. 
Tabela 2.3.2.1. Ensaios de identificação ASTM em geomembranas.

\begin{tabular}{cc}
\hline Ensaio & Norma \\
\hline Espessura & ASTM D 1593 e D 5199 \\
Dassa por unidade & ASTM D 792, D 1505 e D 297 \\
Ensaio de tração uniaxial & ASTM D 3776 e D 5261 \\
Ensaio de tração multiaxial & ASTM D 638 e D 882 \\
Flexibilidade para baixas temperaturas & D 5617 \\
Espectroscopia infravermelho (IR) & ASTM D 1790 e D2136 \\
Calorimetria diferencial de varredura (DSC) & - \\
Análise termogravimétrica (TGA) & ASTM D 3417 e D 3418 \\
Análise termomecânica (TMA) & D 6370 e E 2105 \\
Cromatografia & ASTM D 648 e E 831 \\
Teor de solventes & - \\
"Ash" (cinzas) & ASTM D 297 \\
Dureza & ASTM D 297 \\
Anel e bola (para betume) & ASTM D 2240 \\
Penetração (para betume) & ASTM E 28 \\
Desidrocloronação (para PVC) & ASTM E 28 \\
Teor de negro de fumo (para PEAD) & - \\
Dispersão de carbono (para PEAD) & ASTM D 1603 \\
"Stress crack" (fissuramento) & ASTM D 3015 e D 5596 \\
\hline
\end{tabular}

Tabela 2.3.2.2. Ensaios de Desempenho ASTM em geomembranas.

\begin{tabular}{cc}
\hline Tipo de Ensaio & Norma \\
\hline "Tear" (rasgo) & ASTM D 1004 e D 624 \\
"Bursting" (estouro) & D 3786 \\
Punção & ASTM D 4833 \\
Resistência ao cisalhamento & D 5321 \\
"Creep" (fluência) & ASTM D 5262 \\
Expansão termal & ASTM D 696 \\
Estabilidade dimensional & ASTM D 1204 \\
Permeabilidade (água) & ASTM E 96 \\
Permeabilidade (vapor) & ASTM E 96
\end{tabular}


Tabela 2.3.2.3. Ensaios de Desempenho ASTM em emendas.

\begin{tabular}{cc}
\hline Tipo de ensaio & Norma \\
\hline Ensaio de cisalhamento & ASTM D 4437 e D 4545 \\
Ensaio de descolamento & ASTM D 4437 e D 4545 \\
Ponto de escoamento mecânico & ASTM D 4437 e D 4545 \\
Pressurização das emendas & ASTM D 4437 e D 4545 \\
Aplicação de ar (lance air) & ASTM D 4437 e D 4545 \\
Caixa de vácuo & ASTM D 4437 e D 4545 \\
Plano de impedância ultra - sônico & ASTM D 4437 e D 4545 \\
Ressonância ultra - sônica & ASTM D 4437 e D 4545
\end{tabular}

\subsection{RESISTÊNCIA AO CISALHAMENTO EM BARREIRAS IMPERMEÁVEIS}

\subsubsection{Introdução}

Os sistemas de barreiras impermeáveis em aterros podem ser inclinados, como ocorre quando se deseja proteger uma encosta ou talude. Conseqüentemente, o uso destas barreiras requer uma grande atenção para a análise de estabilidade, devido à presença de interfaces que podem apresentar baixa resistência ao cisalhamento e atuar como uma potencial superfície de deslizamento ou ruptura.

Uma forma de compor barreiras impermeáveis consiste na combinação de solos argilosos compactados e materiais sintéticos. A Figura 2.4.1.1 esquematiza um exemplo de barreira impermeabilizante dupla composta por duas geomembranas, uma georede, uma camada de argila e uma camada granular de drenagem.

Neste caso, a camada granular de drenagem aplica um esforço cisalhante $F_{1}$ na face externa da geomembrana, que pode ser acrescido com a colocação dos resíduos, sobre a geomembrana. Dependendo das características de atrito das superfícies envolvidas, uma porção deste esforço é transmitida por meio de atrito para a georede, resultando no esforço F2. Assim, a diferença de atrito entre as faces destes componentes deve ser resistida pela geomembrana na forma de tensão de tração. Se (Fl- 
F2) for maior do que o limite de escoamento da geomembrana ocorrerá a ruptura do material. Este processo de análise de estabilidade deve ser conduzido para as demais camadas da barreira, e pode ser usado em qualquer tipo e número de interfaces, incluindo geotêxteis e GB (geocompostos bentoníticos).

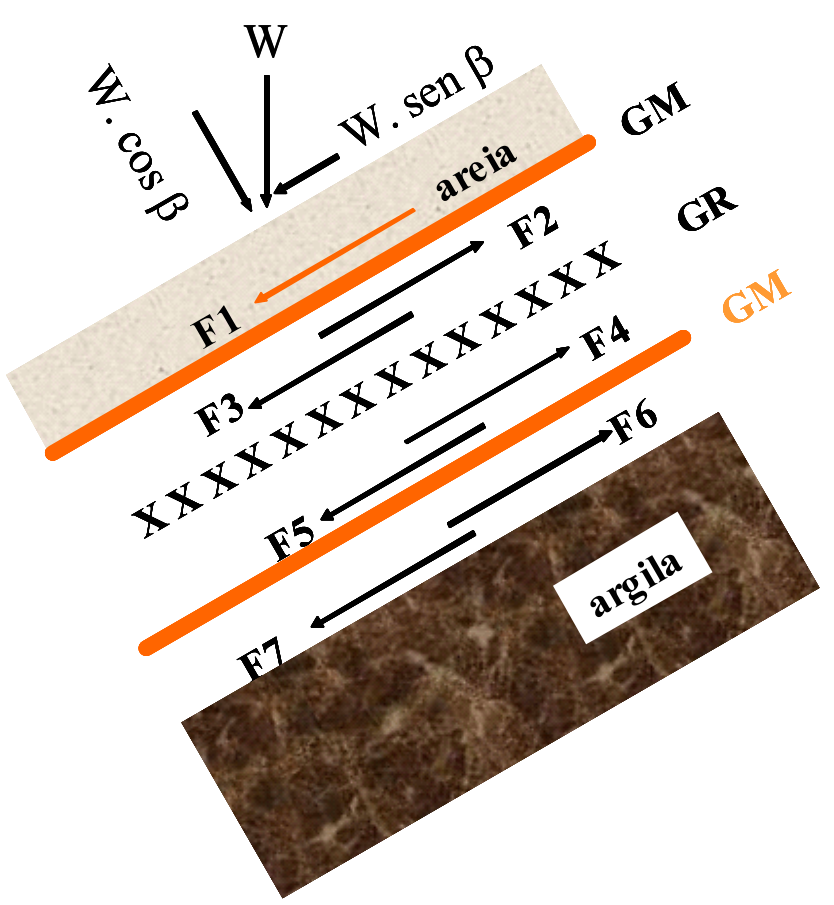

Figura 2.4.1.1. Desenvolvimento de tensões de cisalhamento em liners duplos de sistemas de aterros inclinados (KOERNER, 1994).

Koerner \& Soong (1998) acrescentam algumas situações que devem ser analisadas na estabilidade de aterros sanitários como cargas de equipamento sobre o talude, forças sísmicas atuando sobre o solo de cobertura, uso de solo atuando como bermas e reforço do solo de cobertura utilizando geogrelhas ou geotêxteis.

Existem vários casos de ruptura no sistema de impermeabilização. Dentre estes, destacam-se as rupturas dos aterros de "Kettleman Hills" e "French".

Segundo Mitchell et al. (1990), o aterro de Kettleman Hills, localizado na cidade de Kettleman na Califórnia, destinava-se a resíduos sólidos 
perigosos, e apresentava um sistema duplo de barreiras compostas. 0 aterro apresentava uma altura de 27 metros, quando a ruptura do aterro ocorreu, apresentando deslocamentos laterais da superfície de aproximadamente 11 metros, e recalques verticais do aterro em 4,3 metros. As fissuras na superfície eram claramente visíveis, como também rasgos e deslocamentos sobre a porção exposta do sistema de impermeabilização.

Após a ruptura do aterro, um estudo feito por Mitchell et al. (1990) e Seed et al. (1990), baseado nas observações de campo, ensaios de laboratório, fotografias e análise de estabilidade, concluíram que a ruptura ocorreu nas interfaces geomembrana/argila e geomembrana/georede, devido à baixa resistência ao cisalhamento.

Das investigações realizadas, os principais aspectos observados foram:

- O comportamento na interface entre a camada de argila e a

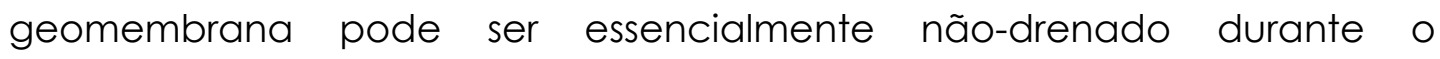
aterramento, e é completamente sensivel ao teor de umidade e ao peso específico seco da argila compactada;

- Houve um rápido decréscimo na resistência de pico para a resistência residual sobre todas as interfaces quando as deformações ocorreram;

- A resistência residual na interface geomembrana/argila pode ser consideravelmente menor que a resistência de pico, e é função da tensão normal;

- Verificou-se também que nas interfaces envolvendo geomembranas de PEAD lisas, a resistência residual é baixa;

- Não foi considerado o efeito da umidade da argila sob um período de chuvas após a construção e antes da colocação da geomembrana no desenvolvimento do projeto e durante a construção do aterro, como ocorreu neste caso.

Segundo Rowe (1998), o aterro sanitário "French" compreende um aterro de resíduos sólidos municipais, com sistema de barreiras compostas de geomembrana lisa de polietileno de alta densidade (PEAD) e de argila 
compactada. A base do aterro consistia de um geotêxtil entre a geomembrana e a argila compactada, com função de proteção da geomembrana. Após a compactação da célula 1, a geomembrana foi instalada durante um período muito chuvoso $(234 \mathrm{~mm}$ de chuva durante o mês da instalação), e os resíduos foram lançados na célula com espessura variando de 12 a 15 metros. O deslizamento do aterro ocorreu em julho de 1994 devido à ruptura nas interfaces geomembrana/argila e geotêxtil/geomembrana na base do aterro. Observou-se que a geomembrana foi arrancada da vala de ancoragem em um comprimento de 60 metros, e um deslocamento no topo dos resíduos de 5 a 6,7 metros.

Das conclusões levantadas por Rowe (1998) para a ruptura do aterro, citam-se a natureza crítica da interface argila/geomembrana, e o decréscimo de resistência de interface em função do teor de umidade proveniente do período de chuvas.

Com base nas possíveis rupturas envolvendo aterros, torna-se essencial um estudo pormenorizado do comportamento de resistência de interface de barreiras impermeáveis. Além disto, é importante conhecer as condições de campo que possam interferir nas propriedades de atrito, e conseqüentemente, na estabilidade do aterro.

\subsubsection{Comportamento de ruptura em aterros}

De acordo com Filz et al. (2001), o comportamento típico para as interfaces envolvendo geossintéticos é o apresentado na Figura 2.4.2.1. Verifica-se que a tensão cisalhante varia de acordo com os deslocamentos, atingindo a condição máxima para pequenos deslocamentos. Após atingir a tensão cisalhante de pico, observa-se um decréscimo de tensão até alcançar a condição residual, a qual é mobilizada para grandes deslocamentos. Este comportamento de resistência pode variar de acordo com a interface analisada e com a magnitude da tensão normal aplicada. 


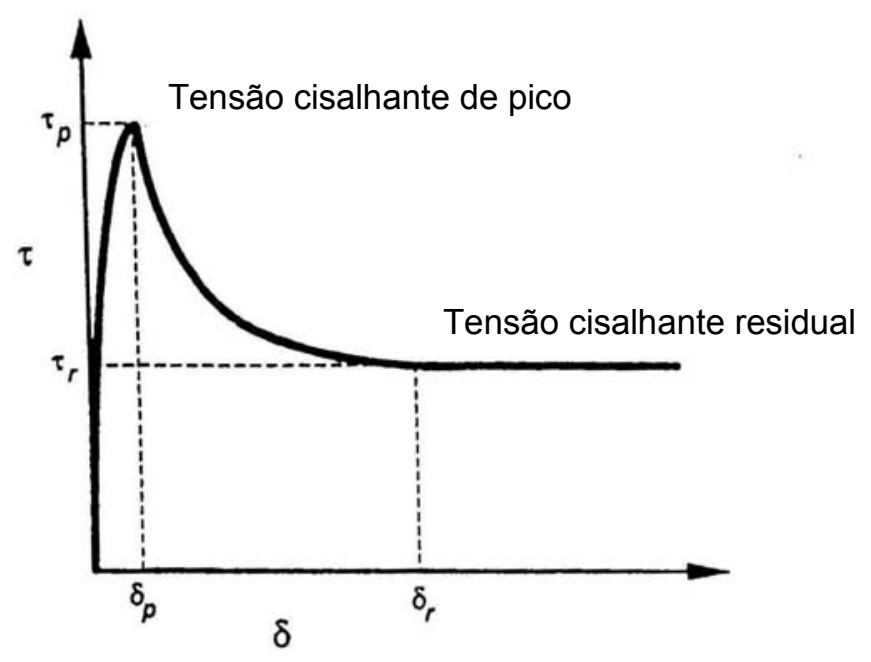

Figura 2.4.2.1. Comportamento típico de tensão de cisalhamento versus deslocamento para interfaces de geossintéticos (FILZ et al., 2001).

Uma vez que a resistência de interface varia com os deslocamentos, deve-se atentar para o mecanismo da ruptura progressiva que ocorre durante o lançamento de resíduos e efluentes.

Filz et al. (2001) explicam o mecanismo de ruptura progressiva tomando-se dois pontos ao longo da curva tensão cisalhante versus deslocamento e em três estágios conforme Figura 2.4.2.2. Durante o estágio I, a altura do aterro é pequena e ocorrem pequenos recalques; logo os deslocamentos por cisalhamento na vizinhança de $A$ e $B$ são pequenos e as tensões de cisalhamento são menores do que o valor de pico em ambas as situações. No estágio II, quando a altura do aterro é maior, ocorrem recalques maiores, o que implica em deslocamentos maiores na interface, principalmente no talude do aterro, com a tensão cisalhante de pico totalmente mobilizada na localização B. Durante o estágio III, grandes deslocamentos induzem uma redução de tensão pós-pico no ponto $B$, enquanto no ponto A os deslocamentos ainda são pequenos, mobilizando a tensão cisalhante de pico. Deste modo, a ruptura progressiva continua até os deslocamentos por cisalhamento em todos os pontos do aterro alcançarem ou ultrapassarem os valores de pico.

Em estudo analítico desenvolvido por Gilbert et al. (1996), verificou-se que, nos taludes de aterros, a magnitude das tensões normais varia com a 
posição em torno da superfície de deslizamento e enquanto os resíduos são lançados.

Estágio $\rightarrow$

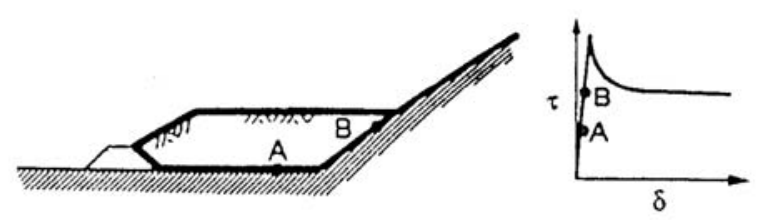

Estágio $\| \rightarrow$

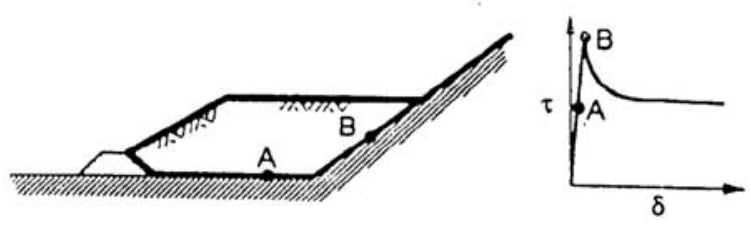

Estágio III $\rightarrow$

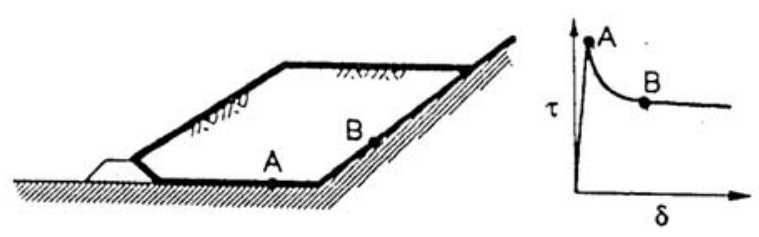

Figura 2.4.2.2. Ruptura progressiva de liners em aterros sanitários (FILZ et al., 2001).

\subsubsection{Análise de estabilidade}

De acordo com Jones \& Dixon (1998), vários métodos de análise estabilidade de taludes contendo geossintéticos têm sido utilizados, como o método do equilíbrio limite de Giroud \& Beech (1989) e Koerner \& HwU (1991), o método limite proposto por Koerner (1994) e, mais recentemente, os métodos de compatibilidade de tensão cisalhante com deformação e com deslocamento desenvolvidos por Long et al. (1994).

Entretanto, os métodos propostos por Giroud \& Beech (1989), Koerner \& HWU (1991) e Koerner (1994) não predizem corretamente 0 comportamento de rupturas em aterros, porque não consideram uma compatibilidade entre força cisalhante e deslocamento ao longo da superfície do liner. Diferentemente destes, no método proposto por Long et al. (1994) é considerado o mecanismo de redução de resistência de interface com o aumento dos deslocamentos, ou seja, o mecanismo de ruptura progressiva. 
Com a finalidade de estudar a ruptura do aterro sanitário de Kettleman Hills, Filz et al. (2001) empregaram o método de elementos finitos na análise de estabilidade. A envoltória de resistência para interfaces geossintéticos/geossintéticos é aproximadamente linear, e a base para os valores de ângulos de atrito na interface utilizados nesta análise é apresentada na Tabela 2.4.3.1. Contudo, observou-se que, conforme retratado por Esterhuizen et al. (2001), a envoltória de resistência para interface geomembrana/argila, em geral, não é linear, sendo utilizados os parâmetros hiperbólicos propostos pelo autor, os quais são apresentados na Tabela 2.4.3.1.

Tabela 2.4.3.1. Ângulos de atrito na interface dos liners de Kettleman Hills.

\begin{tabular}{|c|c|c|c|c|c|c|c|}
\hline \multicolumn{8}{|c|}{ Ângulos de atrito para interface entre geotêxtil e geomembrana } \\
\hline \multicolumn{4}{|l|}{ Fonte } & \multicolumn{2}{|c|}{$\operatorname{Pico}(\delta)$} & \multicolumn{2}{|c|}{ Residual ( $\delta)$} \\
\hline \multicolumn{4}{|l|}{ Seed et al. (1988) - seco } & \multicolumn{2}{|c|}{12.5} & \multicolumn{2}{|c|}{9} \\
\hline \multicolumn{4}{|l|}{ Seed et al. (19880 - úmido } & \multicolumn{2}{|c|}{10.4} & \multicolumn{2}{|c|}{8} \\
\hline \multicolumn{4}{|l|}{ Byrne et al. (1992) } & \multicolumn{2}{|c|}{14} & \multicolumn{2}{|c|}{8} \\
\hline \multicolumn{4}{|l|}{ Stark \& Poeppel (1992) } & \multicolumn{2}{|c|}{8.5} & \multicolumn{2}{|c|}{6} \\
\hline \multicolumn{4}{|c|}{ Valores adotados nesta análise } & \multicolumn{2}{|c|}{11} & \multicolumn{2}{|c|}{6.5} \\
\hline \multicolumn{8}{|c|}{ Valores dos parâmetros hiperbólicos para interfaces de geossintéticos } \\
\hline \multirow[b]{2}{*}{ Grupo dos parâmetros } & \multicolumn{2}{|c|}{ Pico } & \multicolumn{2}{|c|}{ Residual } & & \multirow{2}{*}{$\begin{array}{l}\delta_{\rho}{ }^{\pi} \\
\left({ }^{\circ}\right)\end{array}$} & \multirow{2}{*}{$\begin{array}{c}K_{i} \\
\left(k N / m^{3}\right)\end{array}$} \\
\hline & $\delta\left(\left(^{\circ}\right)\right.$ & $\begin{array}{c}a_{\infty} \\
(k P a)\end{array}$ & $\delta\left(\left(^{\circ}\right)\right.$ & $\begin{array}{c}a_{\infty} \\
(k P a)\end{array}$ & k & & \\
\hline $\begin{array}{l}\text { Kettleman Hills, } \\
\text { argila/geomembrana } \\
\text { Kettleman Hills, } \\
\text { geossintético/geossintético }\end{array}$ & 26 & 72 & 14 & 40 & 25 & 250 & 14.700 \\
\hline
\end{tabular}

Fonte: Filz et al. (2001)

Estes parâmetros hiperbólicos são baseados na equação hiperbólica proposta por GIROUD \& DARRASSE (1993), onde a envoltória de resistência é não linear. A Figura 2.4.3.1 mostra o desenvolvimento da curva hiperbólica proposta por GIROUD \& DARRASSE (1993). 


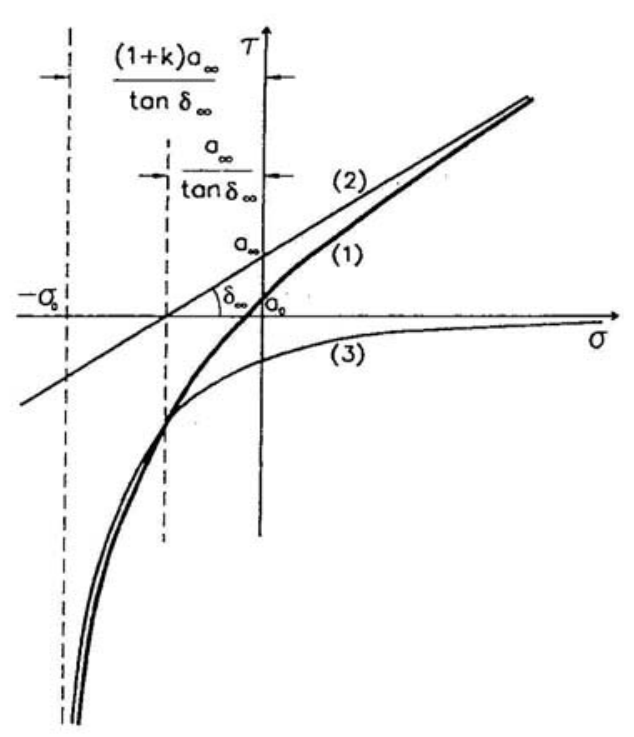

(1) Relação proposta entre $\tau$ e $\sigma$

(2) Assíntota a curva (1)

(3) Hipérbole de ordem $p$

Figura 2.4.3.1- Desenvolvimento da curva hiperbólica de ordem p-(GIROUD \& DARRASSE, 1993).

Tal equação parte do princípio de que a curva real poderia ser côncava e tendendo para uma linha reta para grandes valores de $\sigma$, representada pela curva 1 na Figura 2.4.3.1. Para gerar a relação não linear proposta, uma hipérbole de ordem p com assíntota ortogonal é utilizada para definir a relação não linear entre $e$, sendo representada pela seguinte equação:

$$
\tau=a_{\infty}+\sigma \tan \delta_{\infty}-\left(a_{\infty}-a_{0}\right)\left(1+\sigma / \sigma_{0}\right)^{P}
$$

Onde:

- $\quad$ a $\infty \rightarrow$ intercepto da curva 1 com o eixo $\tau$ (linha reta)

- $\delta \infty \rightarrow$ ângulo de atrito na interface para elevados valores de $\sigma$ (linha reta);

- ao $\rightarrow$ intercepto de adesão para $\sigma$ igual a zero;

- $p$ e $k \rightarrow$ parâmetros sem significado físico.

Os valores de $\mathbf{p}$ e $\mathbf{k}$ podem ser determinados por programas computacionais através do método dos mínimos quadrados, entretanto 
quando não é possível, adota-se k=0 para determinar $\mathbf{p}$, que pode ser obtido pela fórmula abaixo:

$$
p=\ln \left[\left(a_{\infty}-a_{0}\right) /\left(a_{\infty}+\sigma \tan \delta_{\infty}-\tau\right)\right] / \ln \left(1+\sigma \tan \delta_{\infty} / a_{\infty}\right)
$$

Deste modo, a modelagem numérica permitiu que se projetasse gradualmente o lançamento de resíduos no aterro sanitário, com alturas de $12 \mathrm{~m}, 21,3 \mathrm{~m}, 24,5 \mathrm{~m}$ e $27 \mathrm{~m}$. A última altura modelada representou a condição máxima estável na análise, e observou-se no campo a ruptura do talude com $27,4 \mathrm{~m}$ de altura.

Partindo-se da análise do mesmo aterro, porém simulando três diferentes hipóteses, que são apresentadas na Tabela 2.4.3.2, e empregando-se o método de equilíbrio limite, verifica-se que os efeitos da ruptura progressiva foram bastante significativos.

Tabela 2.4.3.2. Comparação das Análises de Equilíbrio Limite (AEL) e Método dos Elementos Finitos (MEF) do aterro de Kettleman Hills.

\begin{tabular}{|c|c|c|c|}
\hline \multirow{2}{*}{$\begin{array}{c}\text { Método de } \\
\text { análise }\end{array}$} & \multicolumn{2}{|c|}{ Resistência de interface } & \multirow{2}{*}{$\begin{array}{c}\text { Altura para } F S=1 \\
(\mathrm{~m})\end{array}$} \\
\hline & Base & Talude & \\
\hline MEF & Progressiva & Progressiva & 27.1 \\
\hline AEL & Residual & Residual & 24.7 \\
\hline AEL & Pico & Residual & 33.5 \\
\hline AEL & Pico & Pico & 36.9 \\
\hline
\end{tabular}

Fonte: Filz et al (2001)

A partir dos resultados apresentados por Filz et al. (2001), destaca-se a importância de se considerar o efeito da ruptura progressiva em taludes de aterros sanitários, e a utilização de parâmetros apropriados de resistência ao cisalhamento nos liners. 


\subsubsection{Tipos de ensaios aplicáveis}

\subsubsection{Ensaio de cisalhamento direto}

Os ensaios de cisalhamento direto são dominantes em função de sua simplicidade de execução e da possibilidade de diversas formas de configuração e fixação de geossintéticos. Devido às suas pequenas dimensões é necessário que haja reversão da caixa para determinação da resistência residual, que por sua vez, influencia os resultados dos ensaios.

Na literatura, são retratados vários ensaios de cisalhamento direto com caixas de diferentes dimensões e/ou modificações no equipamento de modo a facilitar as leituras das medidas de forças e deslocamentos. De acordo com Ingold (1990), dentre os métodos para ensaio de cisalhamento, tem-se:

I. Caixa de cisalhamento fixa $\rightarrow$ Neste ensaio, o geotêxtil ou geomembrana é montado sobre um bloco rígido o qual é colocado na parte inferior da caixa. A metade superior é preenchida com solo, o qual é cisalhado sobre a geomembrana ou geotêxtil.

II. Caixa de cisalhamento parcialmente fixa $\rightarrow \bigcirc$ material sintético é estendido sobre o solo preenchido na metade inferior da caixa. Uma das extremidades do geotêxtil ou geomembrana é fixada na caixa e o solo contido na metade superior é cisalhado sobre a interface.

III. Caixa de cisalhamento livre $\rightarrow$ Este ensaio é similar à caixa parcialmente fixa, entretanto o material sintético está livre de ambos os lados.

IV. Caixa de cisalhamento de grande base $\rightarrow$ Similar à caixa fixa, entretanto a metade inferior da caixa tem uma dimensão plana mais larga que a metade superior contendo o solo. Apresenta como vantagem principal um contato constante da área entre o solo e o material sintético.

V. Caixa de cisalhamento de base central $\rightarrow$ Apresenta o princípio semelhante à caixa de base larga, contudo, a força de atrito gerada no 
geotêxtil ou geomembrana é medida sobre uma área plana menor que a área plana do solo na parte superior da caixa de cisalhamento.

Dos métodos citados por Ingold (1990), os métodos de ensaio I, II e III são realizados com equipamentos normatizados, enquanto os métodos IV e $\checkmark$ requerem equipamentos especiais.

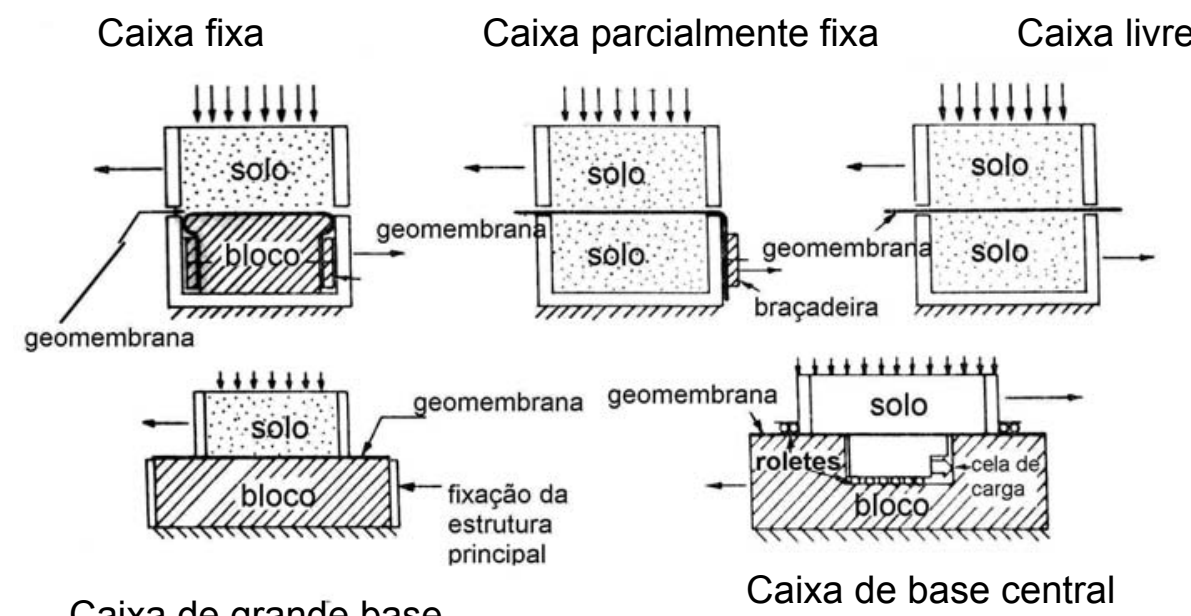

Figura 2.4.4.1.1. Tipos de equipamentos de cisalhamento direto (INGOLD, 1990).

Apesar deste tipo de ensaio ser largamente utilizado, Stark \& Poeppel (1994) afirmam que as amostras são submetidas a pequenos deslocamentos. Como a resistência de pico é mobilizada para pequenos deslocamentos, os ensaios de cisalhamento direto promovem uma boa estimativa da resistência de pico. Entretanto, para a determinação da resistência residual é necessário mobilizar grandes deslocamentos. Deste modo, é necessário que haja reversão da caixa um número de vezes, o que pode ser considerado uma desvantagem. Além disto, a reversão da caixa não permite o deslocamento em uma única direção, logo não simula as condições de cisalhamento de campo que levam a condição de resistência residual. 
De acordo com a ASTM D5321, para ensaios de cisalhamento com interfaces, a caixa de cisalhamento direto requer uma dimensão mínima de $30 \mathrm{~cm}$, e que possibilite um deslocamento contínuo de 2,5 a 7,5cm para mobilização da tensão cisalhante residual. Conseqüentemente, o cisalhamento se realiza no mesmo plano de direção na interface. Entretanto, em função de suas dimensões, apresentam algumas desvantagens como dificuldades de compactação das amostras de solos, o custo do equipamento e a aplicação de grandes carregamentos normais.

\section{Caixa de Cisalhamento de Grande Deslocamento (CCGD)}

De acordo com Shallenberg \& Filz (1996), a Caixa de Cisalhamento de Grande Deslocamento (CCGD) consiste em equipamento desenvolvido para investigar o mecanismo fundamental e aspectos significantes de ensaios de resistência ao cisalhamento em interface. A CCGD apresenta três características fundamentais: grande área de interface, o que reduz a influência dos efeitos de borda; uma seção de ensaio isolada, que possibilita a estimativa dos efeitos de borda, e a capacidade de grandes deslocamentos, que permite a determinação da resistência residual.

O diagrama esquemático da caixa é apresentado na Figura 2.4.4.1.2. A geomembrana é fixada na parte superior do equipamento e cisalhada sobre o material compactado contido na parte inferior, após a aplicação da força normal. O dispositivo superior da caixa apresenta dimensões de 1016 × 406mm, e pode deslocar $305 \mathrm{~mm}$ relativo à caixa do solo. Ainda na parte superior, existe uma seção isolada de ensaio de $305 \times 305 \mathrm{~mm}$, a qual possibilita medidas de resistência e tensões normais distantes das bordas da área de contato. A caixa do solo apresenta $711 \times 406 \mathrm{~mm}$ de dimensão, e a espessura do solo contido na caixa varia de $29 \mathrm{~mm}$ a $79 \mathrm{~mm}$. 


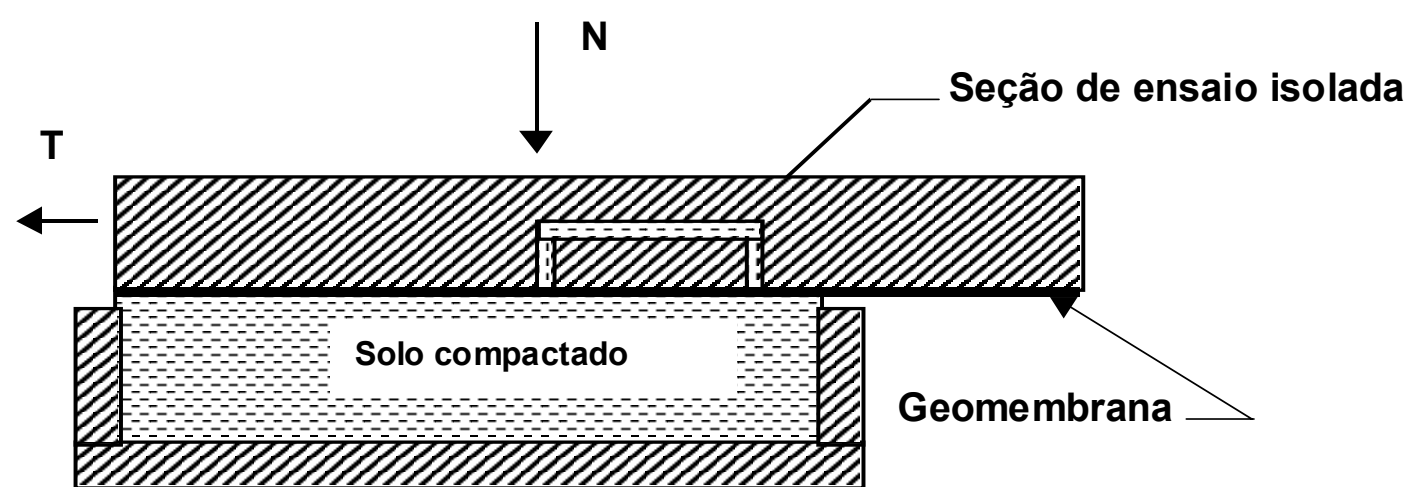

Figura 2.4.4.1.2. Esquema da Caixa de Cisalhamento de Grande Deslocamento (SHALLENBERG \& FILZ, 1996).

Através um programa de ensaios envolvendo geomembranas de PEAD e argila, e através da CCGD, Shallenberg \& Filz (1996) verificaram os efeitos de borda que também condicionam a resistência de interface em liners. A partir dos resultados, verificou-se que a resistência de pico na seção isolada foi 2,0\% maior do que a média da resistência de pico na seção inteira, e uma tendência de arredondamento da curva tensão cisalhante versus deslocamento para a seção inteira. Isto pode ser explicado pela ruptura progressiva da interface próximo às bordas da caixa.

Além disto, os efeitos de borda influenciaram também medidas de resistência residual. Para os mesmos testes conduzidos verificou-se que a resistência residual na seção inteira correspondia um valor 3,7\% maior do que a média da resistência residual sobre a seção do ensaio isolada. Tal efeito pode ser explicado pelo efeito do polimento da geomembrana junto à área de contato, e ao não polimento da geomembrana nas suas extremidades.

\subsubsection{Ensaio de arrancamento ("pull out test")}

Os ensaios de arrancamento também são utilizados para determinação da resistência ao cisalhamento em interfaces. Os ensaios de arrancamento e de cisalhamento direto diferem entre si basicamente pela 
forma com que os esforços são aplicados ao geossintético, pelos mecanismos de ruptura impostos e pelas condições de contorno de cada um. Os parâmetros de resistência da interface obtidos por ambos ensaios podem, conseqüentemente, variar muito de um ensaio para outro e muitas vezes fornecer resultados conflitantes (Farrag et al., 1993). Aliado a isso, o fato de não existir uma padronização para o ensaio de arrancamento talvez possa explicar a discrepância de resultados e conclusões encontrada na literatura.

O ensaio de arrancamento simula com maior fidelidade 0 comportamento de geossintéticos submetidos a esforços de tração. Por sua vez, o ensaio de cisalhamento direto simula bem situações em que ocorre um deslizamento relativo de uma camada de solo sobre o geossintético em relação a uma camada abaixo dela. A Figura 2.4.4.2.1 ilustra esquematicamente os ensaios de cisalhamento direto e de arrancamento.

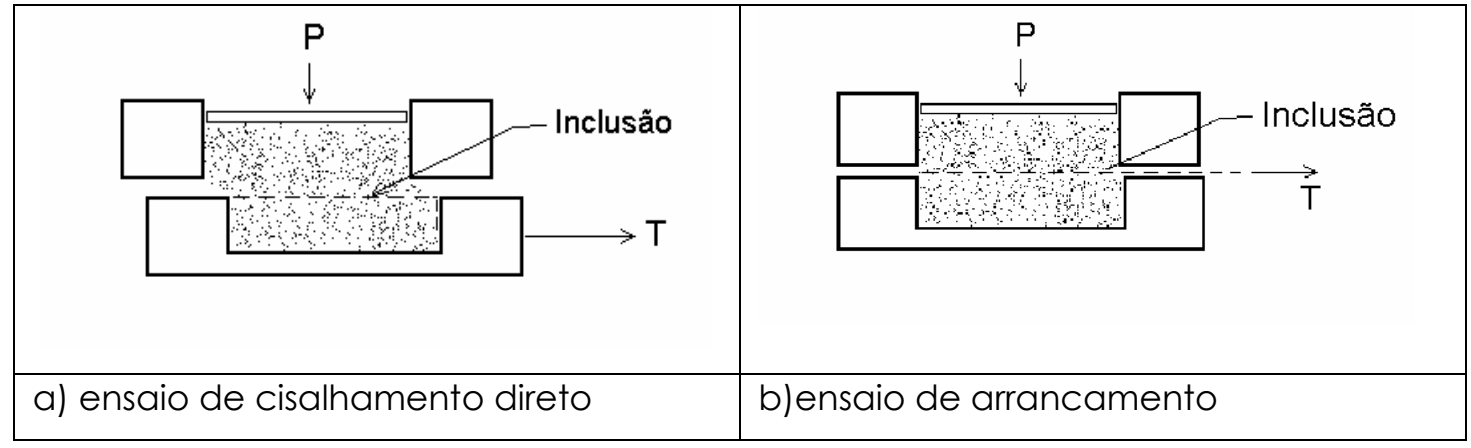

Figura 2.4.4.2.1. Esquema ilustrativo dos ensaios de cisalhamento direto e de arrancamento.

Existem várias configurações para o ensaio de arrancamento. A grande maioria dos equipamentos aplica uma carga distribuída por meio de uma bolsa de ar inflável. As medidas realizadas são, em geral, de força de arrancamento, deslocamentos dos geossintéticos e dilatância. Em alguns equipamentos pode-se controlar a velocidade de arrancamento. As dimensões da caixa do equipamento são as características de maior discrepância dentre os tipos de equipamentos listados. As dimensões médias se aproximam de $1000 \mathrm{~mm}$ de comprimento, $800 \mathrm{~mm}$ de largura e $500 \mathrm{~mm}$ de altura. 
Uma das configurações do ensaio de arrancamento, proposta por Mltchell et al. (1990), é apresentada na Figura 2.4.4.2.2.

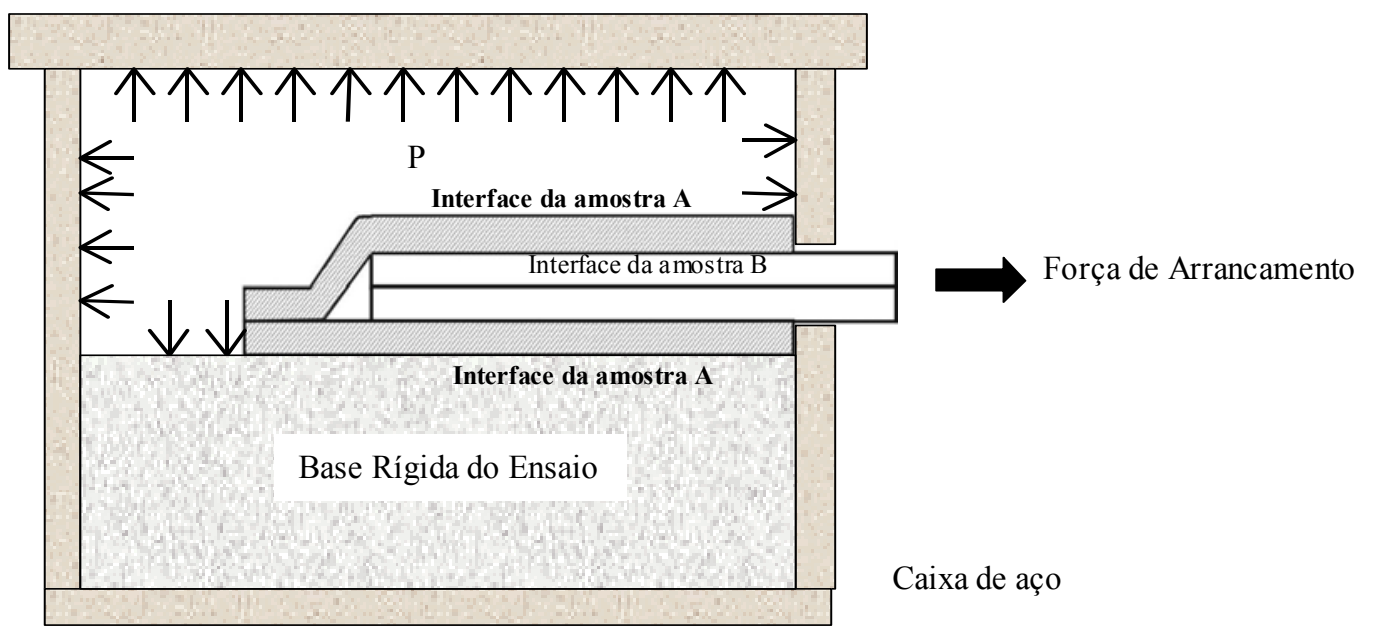

Figura 2.4.4.2.2. Ilustração esquemática do equipamento de ensaios de arrancamento proposto por MITCHELL et al. (1990).

O ensaio de arrancamento retratado por Mitchell et al. (1990) é realizado da seguinte forma: a placa do material da interface A é fixada na reentrância da caixa; duas faixas de material B são cortadas e coladas nas placas de interface A; uma segunda lâmina do material A é colocada no topo das faixas $B$ e fixada no local em uma das extremidades; o topo da caixa de arrancamento é aparafusado, e um diafragma de borracha é colocado no topo da caixa para aplicação da pressão vertical para o sistema "sanduíche" formado; a faixa contendo o material B é arrancada para fora de um dos lados da caixa, com velocidade constante e por meio de um guincho elétrico, sendo a força normal monitorada e controlada pela pressão pneumática.

De acordo com Mitchell et al. (1990), este tipo de ensaio estabelece características de resistência ao cisalhamento e deslocamento por cisalhamento para cada combinação de interface dentro de uma faixa de deslocamentos muito maior do que é possível pelo ensaio de cisalhamento direto. Além disto, permite uma comparação entre os resultados apresentados por estes dois tipos de ensaios. 
Ainda segundo Mitchell et al. (1990), através de uma série de ensaios realizados, pôde-se verificar que existe uma boa concordância entre as características de resistência residual medidas no cisalhamento direto e nos ensaios de arrancamento, o que confirma o uso de ensaios simples de cisalhamento direto para a determinação da resistência de interface.

\subsubsection{Ensaio de cisalhamento com plano inclinado}

O equipamento de plano inclinado consiste em uma mesa articulada em uma das extremidades e elevada em outra extremidade até que ocorram escorregamentos em torno da interface. Várias configurações para o equipamento podem ser encontradas na literatura, sendo que o princípio do ensaio é semelhante, independente de sua configuração.

Basicamente, o ensaio consiste em uma caixa rígida que confina a massa do solo apoiada sobre o geossintético fixa a um plano, inicialmente posicionado horizontalmente. A inclinação do plano é aumentada até ocorrer o deslizamento ao longo da interface.

No equipamento proposto por Izgin \& Wasti (1998), a bandeja retangular, onde são contidos os materiais, apresenta dimensões de dimensões de $600 \times 490 \times 25 \mathrm{~mm}$. Ao contrário dos ensaios de cisalhamento direto, são conduzidos para pequenas tensões normais, variando ente 5 a $50 \mathrm{kPa}$. Segundo estes autores, acredita-se que para baixas tensões normais, pode não ser exato o resultado de ensaios de cisalhamento direto devido às dificuldades mecânicas. Este tipo de ensaio é conduzido para pequenas tensões normais porque tensões maiores podem induzir a um significante momento e conseqüente tombamento do bloco.

Entretanto, Izgin \& Wasti (1998) afirmam que a limitação da magnitude não é considerada uma desvantagem, visto que o ensaio de cisalhamento sob plano inclinado reproduz as condições reais mais precisamente nos sistemas onde as tensões normais são geralmente baixas.

A Figura 2.4.4.3.1 apresenta o equipamento de plano inclinado proposto por Izgin \& Wasti ( 1998). 


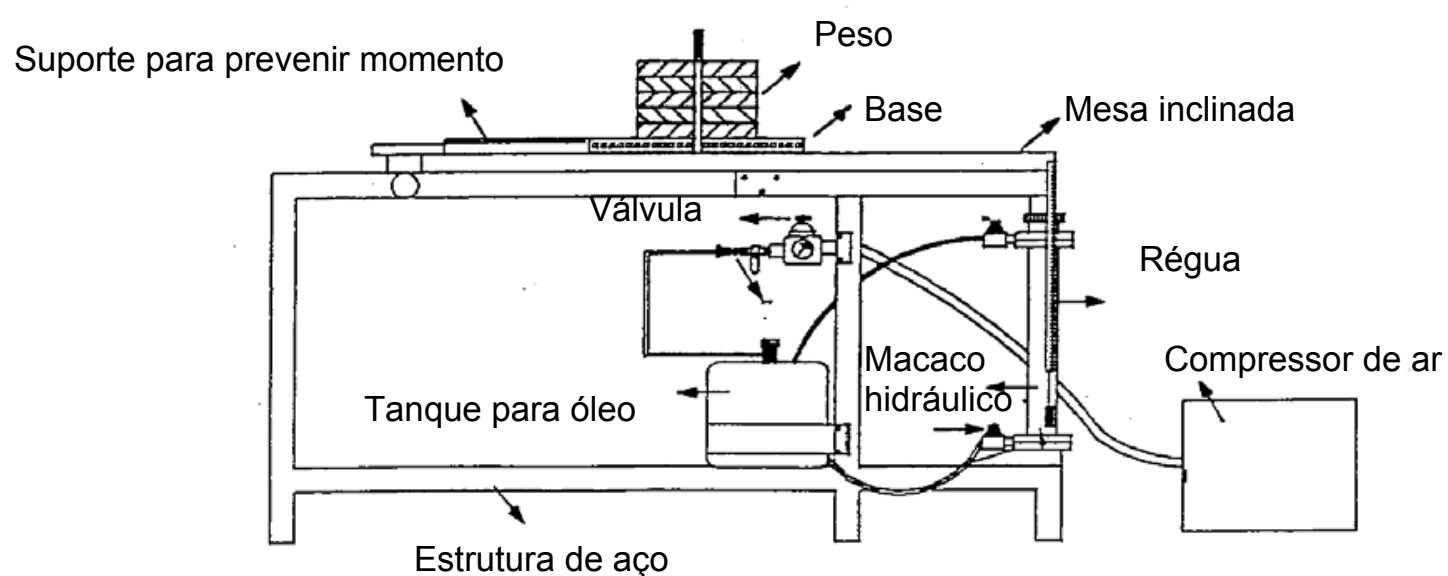

Figura 2.4.4.3.1. Equipamento modificado para ensaio de plano inclinado (IZGIN \& WASTI, 1998).

Cita-se ainda o equipamento de plano inclinado proposto por Mello et al. (2003) e Jr. Lima e Palmeira (2003). Tais trabalhos apresentam os resultados de ensaios de rampa ou de plano inclinado de grandes dimensões, realizados com diferentes solos e geossintéticos. Segundo estes autores, os equipamentos típicos utilizam caixas de solos com áreas de interface variando de 0,005 a $1 \mathrm{~m}^{2}$. Apesar da simplicidade do ensaio, este apresenta algumas limitações como a variação da tensão normal sobre a rampa com a inclinação da rampa e a forma de distribuição da tensão normal, a qual é admitida uniforme ao longo da interface, o que não corresponde à realidade.

Mello et al. (2003) e Jr. Lima e Palmeira (2003) verificaram em seus trabalhos que as dimensões da amostra podem afetar significativamente os valores de tensões atuantes na interface. Uma das alternativas consiste na utilização de caixas com faces laterais inclinadas, de modo que as mesmas coincidam com a vertical no instante da ruptura da interface. Tal procedimento promove uma uniformização na distribuição de tensões normais na interface. Outra alternativa consiste na utilização de caixas com elevadas relações comprimento-altura. No equipamento proposto por estes autores, as dimensões internas da caixa de confinamento da amostra de solo são de $1920 \mathrm{~mm} \times 250 \mathrm{~mm} \times 470 \mathrm{~mm}$. 


\subsubsection{Ensaio de ring shear}

Conforme observado por Negussey et al. (1989); Tan et al. (1998), a resistência ao cisalhamento residual corresponde a um parâmetro de projeto importante para estruturas geotécnicas, que necessitam de resistir a grandes deslocamentos por cisalhamento, como ocorre em taludes de contenção de resíduos.

De acordo com Head (1994), o ensaio de ring shear foi desenvolvido com a finalidade inicial de estimar as resistências residuais de solos argilosos, sendo posteriormente modificado e utilizado com outros materiais.

No equipamento modificado proposto por Bromhead (1979), o anel apresenta diâmetros externo e interno de $100 \mathrm{~mm}$ e $70 \mathrm{~mm}$, respectivamente, e profundidade de $5 \mathrm{~mm}$.

De acordo com Stark \& Poeppel (1994); Tan et al. (1998), o ensaio de cisalhamento em anel apresenta como vantagem principal a continuidade dos deslocamentos por cisalhamento que podem ser aplicados em uma direção até atingir a condição de resistência residual. Além disto, cita-se também a presença de uma área seccional constante durante o cisalhamento. Contudo, devido às pequenas dimensões dos corpos de prova, não se aplicam em materiais que são significantemente anisotrópicos.

Segundo Stark \& Poeppel (1994) e conforme um estudo da ruptura do aterro de Kettleman Hills, verificou-se através de análises de estabilidade bi e tridimensional, que a estimativa dos parâmetros de resistência ao cisalhamento obtidos por ensaios torsionais são condizentes com as condições "in situ". Tan et al. (1998), comparando os resultados de ensaios de cisalhamento direto e torsionais em interface geotêxtil/areia, verificaram que os valores de ângulo de atrito obtidos nos ensaios de cisalhamento direto são maiores do que os valores obtidos para ensaios torsionais, em função dos limites do equipamento.

Este equipamento, por se tratar do ensaio proposto para este trabalho, será discutido com maiores detalhes em capítulo à parte. $\mathrm{Na}$ Figura 2.4.4.4.1 é apresentado o diagrama esquemático do ensaio. 


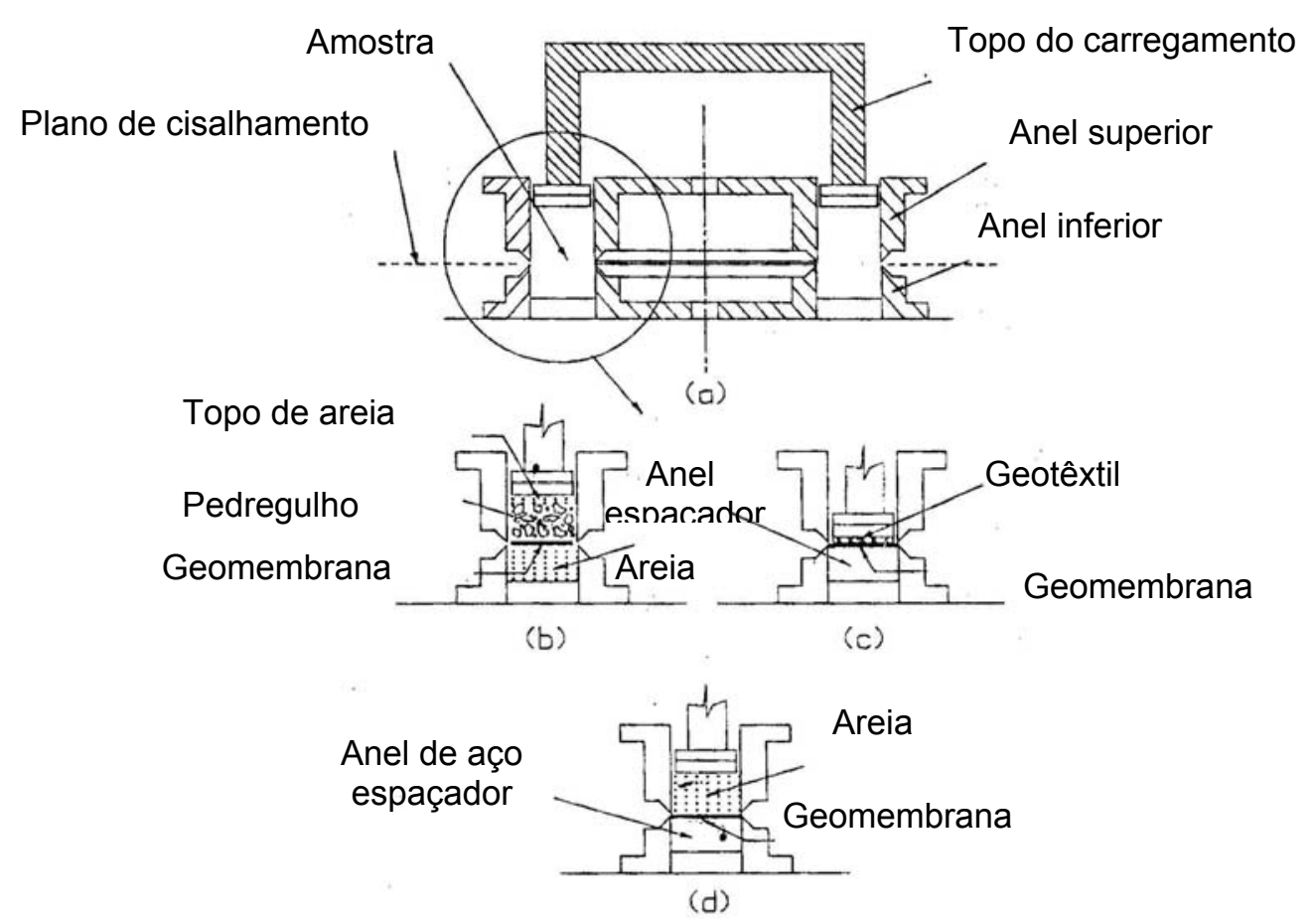

Figura 2.4.4.4.1. Diagrama esquemático do equipamento de cisalhamento em anel e das interfaces de cisalhamento (NEGUSSEY et al., 1989).

\subsubsection{Ensaio de cisalhamento com mesa vibratória}

Conforme Yegian \& Lahlaf (1992) vários resultados de ensaios estáticos são retratados na literatura com aplicação direta na análise de estabilidade estática de instalações geotécnicas que incluam geossintéticos. Todavia, o comportamento dinâmico ainda não é adequadamente aplicado em projetos ou pesquisas que envolvam geossintéticos devido a ações estáticas como sismos, plano de fogo ou vibrações induzidas pelo homem ou máquinas.

O objetivo do ensaio dinâmico é estimar o ângulo de atrito dinâmico na interface de materiais sintéticos. Consiste na vibração da mesa por meio de um excitador eletrodinâmico, cuja aceleração induz a uma força que é transmitida ao bloco. A partir das medidas de aceleração, por meio de um acelerômetro, e dos deslocamentos do bloco relativo à mesa, medidos através de um transdutor de deslocamento linear, os dados 
podem ser analisados para determinação do ângulo de atrito dinâmico em interfaces.

Através de um programa experimental com ensaios estáticos e dinâmicos, Yegian \& Lahlaf (1992) puderam investigar o comportamento dinâmico em interface geomembrana/geotêxtil. Nos resultados observados, verificou-se que a diferença entre os ensaios estáticos, utilizando-se da mesma mesa, porém sem estimulação, e os ensaios dinâmicos é muito pequena. Além disto, os ensaios de cisalhamento com mesa vibratória provêm adequadamente valores de ângulo de atrito dinâmicos tão bem quanto para ângulos de atritos de pico e residual estáticos. Para a condição submersa verificou-se o mesmo efeito. Também apresentam a vantagem de facilitar o uso de amostras grandes e representativas de geossintéticos. Contudo, são limitados a interfaces de materiais sintéticos envolvendo geomembranas e geotêxteis.

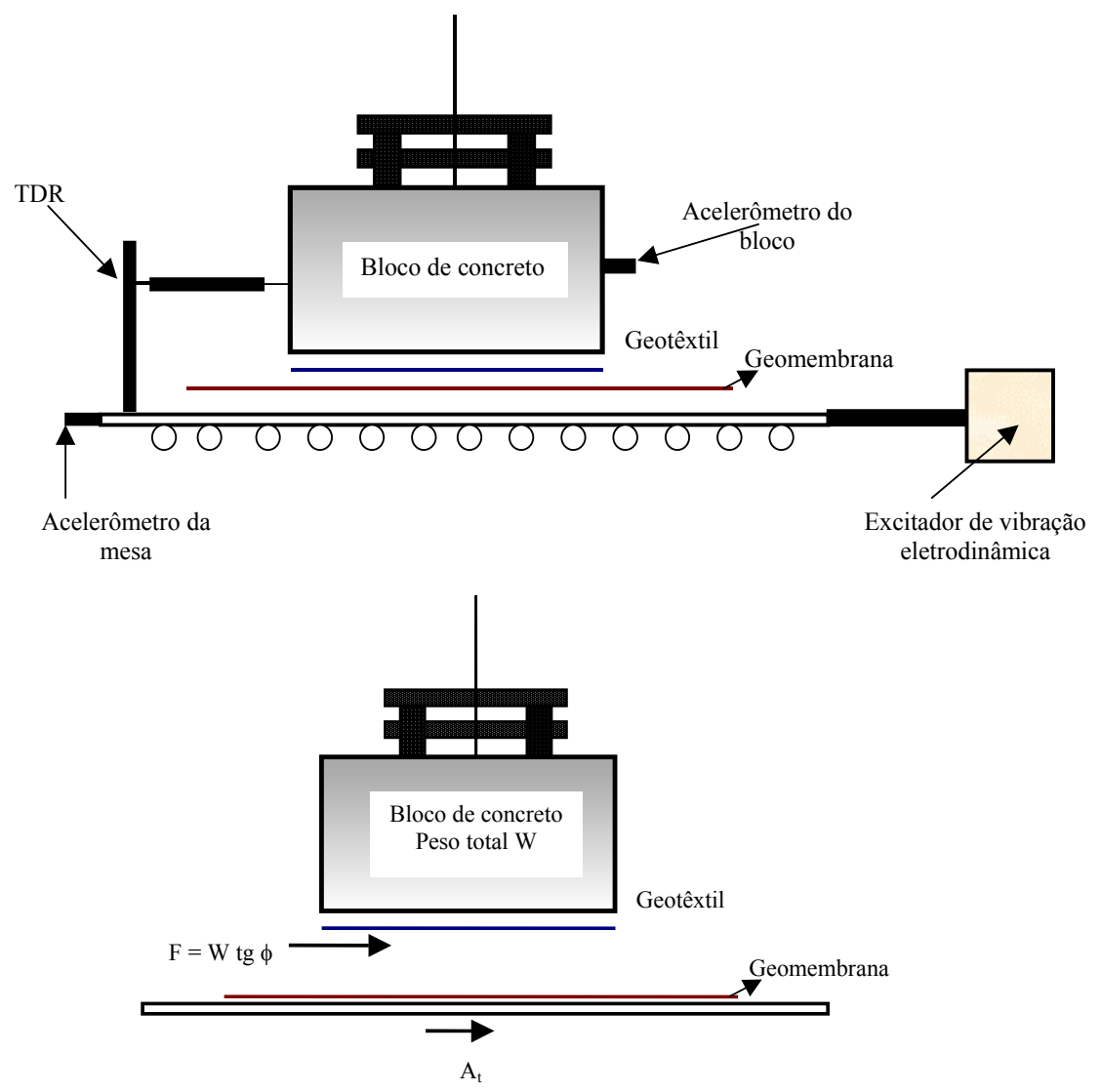

Figura 2.4.4.5.1. Ilustração esquemática da mesa vibratória (YEGIAN \& LAHLAF, 1992). 


\subsubsection{Valores típicos de ângulos de atrito de interfaces}

Alguns valores de ângulos de atrito obtidos por Martin et al. apud Ingold (1990) são apresentados nas Tabelas 2.4.5.1 , 2.4.5.2 e 2.4.5.3.

Tabela 2.4.5.1. Ângulo de atrito para interface solo/geomembrana

\begin{tabular}{lccc}
\hline \multirow{2}{*}{ Geomembrana } & \multicolumn{3}{c}{ Tipo de Solos } \\
\cline { 2 - 4 } & Areia para concreto & Areia Ottawa & Areia micácea \\
\hline PELMD & $24^{\circ}$ & $20^{\circ}$ & $24^{\circ}$ \\
PVC & & & \\
\multicolumn{1}{r}{ Texturizada } & $27^{\circ}$ & - & $25^{\circ}$ \\
& $25^{\circ}$ & - & $21^{\circ}$ \\
PECS & $25^{\circ}$ & $21^{\circ}$ & $23^{\circ}$ \\
PEAD & $18^{\circ}$ & $18^{\circ}$ & $17^{\circ}$ \\
\hline
\end{tabular}

Fonte: after Martin et al. apud Ingold (1990)

Tabela 2.4.5.2. Ângulo de atrito para interface geomembrana/geotêxtil.

\begin{tabular}{lccccc}
\hline & \multicolumn{5}{c}{ Geomembrana } \\
\cline { 2 - 6 } Geotêxtil & MDPE & PVXturizada & Lisa & PECS & PEAD \\
\hline CZ 600 & $23^{\circ}$ & $23^{\circ}$ & 210 & $15^{\circ}$ & 80 \\
Typer 3401 & 180 & 200 & 180 & 210 & 110 \\
Polyfilter X & 170 & 110 & 100 & 90 & 60 \\
$500 X$ & 210 & 280 & 240 & 130 & 100 \\
\hline
\end{tabular}

Fonte: after Martin et al. apud Ingold (1990)

Tabela 2.4.5.3. Ângulo de atrito para interface solo/geotêxtil.

\begin{tabular}{lccc}
\hline \multirow{2}{*}{ Geotêxtil } & \multicolumn{3}{c}{ Tipo de Solos } \\
\cline { 2 - 4 } & $\begin{array}{c}\text { Areia concreto } \\
\left(\phi=30^{\circ}\right)\end{array}$ & $\begin{array}{c}\text { Areia Ottawa } \\
\left(\phi=\mathbf{2 8}^{\circ}\right)\end{array}$ & $\begin{array}{c}\text { Areia mica Schist } \\
(\phi=\mathbf{2 6})\end{array}$ \\
\hline CZ 600 & $30^{\circ}$ & $26^{\circ}$ & $25^{\circ}$ \\
Typer 3401 & $26^{\circ}$ & - & - \\
Polyfilter X & $26^{\circ}$ & - & - \\
$500 X$ & $24^{\circ}$ & $24^{\circ}$ & $23^{\circ}$ \\
\hline
\end{tabular}

Fonte: after Martin et al. apud Ingold (1990) 
De acordo com Bouazza et al. (2002) vários valores de resistência ao cisalhamento em interfaces são encontrados na literatura. Esta gama de valores é atribuída por estes autores à variabilidade dos geossintéticos, as condições de ensaio e aos equipamentos empregados. Na Tabela 2.4.5.4 são apresentados alguns valores de resistência propostos por Bouazza et al. (2002).

Tabela 2.4.5.4. Valores dos parâmetros de resistência de diferentes interfaces.

\begin{tabular}{|c|c|}
\hline \multicolumn{2}{|c|}{ INTERFACE SOLO - GEOSSINTÉTICO } \\
\hline GM PEAD - areia & $\delta=15^{\circ}$ a $28^{\circ}$ \\
\hline GM PEAD - argila & $\delta=5^{\circ}$ a $29 \circ$ \\
\hline GT - areia & $\delta=22^{\circ}$ a $44^{\circ}$ \\
\hline GCL - areia & $\delta=20^{\circ}$ a $25^{\circ}$ \\
\hline GCL - argila & $\delta=14^{\circ}$ a $16^{\circ}$ \\
\hline PEAD texturizada - argila compactada & $\delta=7^{\circ}$ a $35^{\circ}$ \\
\hline & $c^{\prime}=20$ a $30 \mathrm{kPa}$ \\
\hline $\begin{array}{l}\text { PEAD texturizada- pedregulhos } \\
\text { pequenos }\end{array}$ & $\delta=20^{\circ}$ a $25^{\circ}$ \\
\hline PEAD texturizada - areia & $\delta=30^{\circ}$ a $45^{\circ}$ \\
\hline GT - argila & $\delta=15^{\circ} \mathrm{a} 33^{\circ}$ \\
\hline \multicolumn{2}{|c|}{ INTERFACE GEOSSINTÉTICO - GEOSSINTÉTICO } \\
\hline Georede - GM PEAD & $\delta=6^{\circ}$ a $10^{\circ}$ \\
\hline GM PEAD - GT & $\delta=8^{\circ}$ a $18^{\circ}$ \\
\hline GT - GR & $\delta=10^{\circ}$ a $27^{\circ}$ \\
\hline \multirow{2}{*}{$G C L-G C L$} & $\delta=8^{\circ}$ a $25^{\circ}$ \\
\hline & $c^{\prime}=8$ a $30 \mathrm{kPa}$ \\
\hline PEAD texturizada - GR & $\delta=10^{\circ}$ a $25^{\circ}$ \\
\hline PEAD texturizada - GT & $\delta=14 \circ$ a $52^{\circ}$ \\
\hline
\end{tabular}

Fonte: Bouazza et al. (2002).

\subsubsection{Fatores condicionantes}

Com base nos estudos de resistência ao cisalhamento em interfaces de liners envolvendo vários tipos de ensaios, verificou-se que tal resistência é 
condicionada por uma série de fatores. Tais fatores são analisados e discutidos separadamente por questões práticas.

\section{Influência dos ciclos de cisalhamento}

Para determinação da resistência residual em interfaces envolvendo geossintéticos é necessário que sejam mobilizados grandes deslocamento, dependendo do tipo de interface. Em função das dimensões dos equipamentos, como as caixas de cisalhamento direto, é necessário que haja reversão da caixa, e que a interface seja submetida a mais de um ciclo de cisalhamento.

Para verificar o efeito do número de ciclos de cisalhamento, Pasqualini \& Sani (1993) realizaram ensaios de cisalhamento direto envolvendo interfaces de geomembrana de PEAD lisa e geotêxtil de PET 400 não tecido agulhado, e interfaces de geomembrana PEAD lisa e georede de PEAD 500.

A partir dos resultados dos ensaios, observou-se que, para a interface geomembrana/geotêxtil, no primeiro ciclo a resistência de pico é bem definida e obtida para deformações pequenas. Depois a resistência ao cisalhamento tende para um valor residual. Nos ciclos subseqüentes, a diferença entre a resistência de pico e a residual é menos marcada, e o valor da resistência residual não é significantemente condicionado pelo número de ciclos.

Seed et al. (1990) atribuem estes efeitos a um possível efeito de polimento da interface do geotêxtil sobre a geomembrana; sendo também possível, após o primeiro ciclo, que as fibras do geotêxtil tornem-se aplainadas e orientadas. Entretanto, observa-se uma tendência diferente na interface geomembrana/georede, na qual há um aumento significativo na resistência ao cisalhamento após o primeiro estágio. Este aumento de resistência é atribuído ao aumento de rugosidade da superfície do PEAD devido à passagem anterior da geogrelha sobre a geomembrana. 


\section{Influência da temperatura}

A temperatura corresponde a um parâmetro muito importante para todos os materiais poliméricos. Os ensaios retratados por Pasqualini \& Sani (1993) para verificar tal influência foram realizados num verão muito quente de 1992, com temperaturas variando entre $25^{\circ}$ e $30^{\circ} \mathrm{C}$. Os resultados apresentados na Tabela 2.4.6.1 mostram que a influência da temperatura sobre a resistência ao cisalhamento deve ser investigada sistematicamente.

Tabela 2.4.6.1. Ângulos de atrito residual versus temperatura.

\begin{tabular}{|c|c|c|c|}
\hline \multirow{2}{*}{ Interface } & \multirow{2}{*}{$\begin{array}{l}\text { Tensão normal } \\
\qquad \begin{array}{c}(\mathrm{kPa}) \\
\text { on }\end{array}\end{array}$} & \multicolumn{2}{|c|}{$\begin{array}{l}\text { Ângulo de atrito residual } \\
\qquad \delta_{r}\end{array}$} \\
\hline & & $\begin{array}{l}\text { Temperatura } \\
260 \mathrm{C}-270 \mathrm{C}\end{array}$ & $\begin{array}{l}\text { Temperatura } \\
290 \mathrm{C}-300 \mathrm{C}\end{array}$ \\
\hline $\begin{array}{c}\text { GM lisa PEAD (1 mm)/ } \\
\text { GT PET } 300 \text { (não } \\
\text { tecido) }\end{array}$ & 25 & $13.8^{\circ}$ & 15.90 \\
\hline $\begin{array}{c}\text { GM lisa PEAD (1 mm)/ } \\
\text { GT PET } 300 \text { (não } \\
\text { tecido) }\end{array}$ & 86 & $12.6^{\circ}$ & 16.00 \\
\hline $\begin{array}{l}\text { GM lisa PEAD (1 mm)/ } \\
\text { GT PP } 500 \text { (tecido) }\end{array}$ & 25 & $12.4^{\circ}$ & 14.70 \\
\hline $\begin{array}{l}\text { GM lisa PEAD (1 mm)/ } \\
\text { GT PP } 500 \text { (tecido) }\end{array}$ & 86 & 11.70 & $14.5^{\circ}$ \\
\hline $\begin{array}{l}\text { GM lisa PEAD (1 mm)/ } \\
\text { GT PP } 470 \text { (tecido) }\end{array}$ & 25 & $12.2^{\circ}$ & $17.4^{\circ}$ \\
\hline $\begin{array}{l}\text { GM lisa PEAD (1 mm)/ } \\
\text { GT PP } 470 \text { (tecido) }\end{array}$ & 86 & 13.30 & 17.70 \\
\hline
\end{tabular}

Fonte: Pasqualini \& Sani (1993)

\section{Condição de umidade das amostras}

Nos ensaios desenvolvidos para três interfaces distintas, em condições seca e úmida, mas não submersas, Pasqualini \& Sani (1993) 
observam que a resistência ao cisalhamento dos materiais sob condições úmidas é menor do que a resistência seca. Nos ensaios desenvolvidos na interface entre geotêxtil PP470 tecido e geomembrana de PEAD lisa, e apresentado na Tabela 2.4.6.2, pôde-se verificar tal aspecto.

Tabela 2.4.6.2. Ângulos de atrito residual em condições seca e úmida.

\begin{tabular}{ccccc}
\hline \multirow{2}{*}{ Interface } & $\begin{array}{c}\text { Tensão normal } \\
(\mathbf{K P a})\end{array}$ & \multicolumn{3}{c}{ Ângulo de atrito residual } \\
& on & Seca & $\delta$ Úm & Úmida \\
\hline Geomembrana & 25 & $12.2 \circ$ & 11.10 \\
PEAD lisa / & 51 & 12.80 & 11.10 \\
geotêxtil PP470 & 69 & 12.90 & 10.70 \\
tecido & 86 & 13.30 & 10.70 \\
\hline
\end{tabular}

Fonte: Pasqualini \& Sani (1993)

\section{Influência das tensões normais}

Ainda de acordo com os ensaios realizados por Pasqualini \& Sani (1993), envolvendo interfaces geomembrana/geotêxtil e geomembrana/ georede, pôde-se verificar que a resistência ao cisalhamento depende do nível de tensão normal aplicado para quaisquer condições de umidade dos materiais. A Figura 2.4.6.1 mostra a influência da tensão normal para interface geomembrana/geotêxtil.

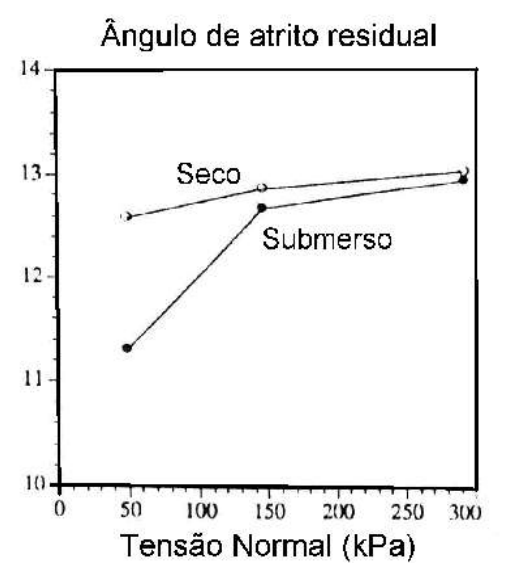

Figura 2.4.6.1. Influência da tensão normal sobre a resistência ao cisalhamento sob condições seca e úmida(Pasqualini \& Sani, 1993). 
Observa-se que com o aumento da tensão normal ocorre um aumento nos ângulos de atrito, principalmente nos ensaios submersos. Além disto, verifica-se que à medida que as tensões normais aumentam, a diferença entre os ângulos de atrito na condição seca e submersa tende a decrescer. Para os ensaios realizados em interfaces geomembrana/georede, confirmaram-se os baixos valores de resistência ao cisalhamento esperados para este tipo de interface, e também se observou o mesmo efeito de aumento da resistência com acréscimos de tensão normal.

\section{Influência do teor de umidade dos materiais argilosos}

Neste aspecto, foram desenvolvidos ensaios de interface com geomembrana de PEAD e diferentes solos argilosos $\left(\mathrm{H}_{1}\right.$ e $\left.\mathrm{H}_{2}\right)$, realizados sob condição não submersa e submersa. Os primeiros testes realizaram-se em condição não submersa, e na segunda série de ensaios, as amostras foram saturadas durante 24 horas sob uma sobrecarga de $25 \mathrm{kPa}$. Os resultados são apresentados por Pasqualini \& Sani (1993) na Tabela 2.4.6.3.

Tais resultados indicam que a tensão cisalhante na amostra $\mathrm{H}_{1}$ diminui quando passa da condição não submersa para a condição submersa. Na amostra $\mathrm{H}_{2}$, a qual apresenta umidade ótima $5 \%$ acima da $H_{1}$, observa-se que a diferença entre a tensão cisalhante nos ensaios não submersos e submersos é pequena. 
Tabela 2.4.6.3. Valores da resistência de cisalhamento, $\tau_{F}$, para materiais argilosos com diferentes densidades e teores de umidade.

\begin{tabular}{ccccc}
\hline \multirow{2}{*}{ Interface } & $\begin{array}{c}\text { Tensão normal } \\
\sigma_{\mathrm{N}}(\mathrm{KPa})\end{array}$ & \multicolumn{2}{c}{ Ensaio seco } & Ensaio submerso \\
& 66 & $\delta_{\mathrm{R}}\left({ }^{\circ}\right)$ & $\tau_{\mathrm{F}}(\mathrm{KPa})$ & $\tau_{\mathrm{F}}(\mathrm{KPa})$ \\
\hline $\mathrm{H} 1$ & 120 & $13.8^{\circ}$ & 16.3 & $14.5^{\circ}$ \\
& 214 & $13.8^{\circ}$ & 35.2 & $25.7^{\circ}$ \\
& 66 & $13.0^{\circ}$ & $15.3^{\circ}$ & $46.4^{\circ}$ \\
$\mathrm{H} 2$ & 120 & $11.1^{\circ}$ & $24.4^{\circ}$ & $14.0^{\circ}$ \\
& 214 & $10.3^{\circ}$ & $39.5^{\circ}$ & $24.4^{\circ}$ \\
& & & & $39.8^{\circ}$ \\
\hline
\end{tabular}

Fonte: Pasqualini \& Sani (1993)

Legenda: $\quad H 1: \gamma_{d}=1.62 \mathrm{gf} / \mathrm{cm}^{3} \quad \mathrm{~W}=\mathrm{W}_{\mathrm{otm}}=21 \%$

$\mathrm{H} 2: \gamma_{\mathrm{d}}=1.55 \mathrm{gf} / \mathrm{cm}^{3} \quad \mathrm{~W}=\mathrm{W}_{\mathrm{otm}}=26 \%$

Influência do fenômeno de tixotropia

Outro fator condicionante retratado por Shallenberg \& Filz (1996) diz respeito à influência de tixotropia verificada após o tempo de compactação das amostras de solo. Mitchell (1993) explica que, após o tempo de compactação, a estrutura da argila tende a acomodar para um nível de energia mais baixo, e durante este processo a estrutura torna-se mais floculada. Conseqüentemente, ocorre dissipação das pressões neutras com o tempo após a compactação, que tende a um aumento da resistência ao cisalhamento com o tempo.

Este efeito, denominado tixotropia, é importante para o desenvolvimento e comparação dos ensaios de laboratório e para o desenvolvimento de sistemas de liners no campo. O efeito benéfico da tixotropia na resistência de interface pode não ser tão marcante no campo devido a mudanças simultâneas na argila que ocorrem em resposta à consolidação. 


\section{Efeito do adensamento da argila}

Gómez \& Filz (1999) retratam que a colocação de rejeitos sobre barreiras compostas provoca o adensamento da camada de argila. Freqüentemente têm-se assumido que o adensamento que ocorre na camada de argila é muito pequeno devido aos baixos valores de coeficiente de consolidação esperados para barreiras de argila compactada.

Para investigar a influência deste efeito foram realizados ensaios através da caixa de cisalhamento de grande deslocamento (CCGD) em condições UU (não consolidados e não drenados) e CU (consolidados e não drenados), utilizando-se de geomembrana lisa de polietileno de alta densidade (PEAD) e argila obtida pelo Old Dominion Sanitary Landfill (ODSL). A partir dos resultados dos ensaios, Gómez \& Filz (1999) verificaram que, nas espécies compactadas com umidade $6,5 \%$ acima da ótima, a consolidação produziu aumentos muito grandes na resistência de interface. Observou-se também que o aumento de resistência devido à consolidação é muito maior do que devido ao fenômeno de tixotropia.

Entretanto, deve-se ter uma certa ressalva quanto a estes dados, devido à dificuldade de compactação do solo com umidade tão elevada.

\section{Influência das condičões de compactação das amostras de solo}

As características de permeabilidade de solos coesivos utilizados como barreiras impermeáveis são controladas pelo teor de umidade de compactação e pelo peso específico seco. As condições sob as quais o material é compactado afetam não somente a permeabilidade, como também a resistência ao cisalhamento na interface geomembrana/solo coesivo.

Seed \& Boulanger (1991) relatam os efeitos da compactação na resistência ao cisalhamento de interface baseado em ensaios de laboratório utilizando-se geomembrana de PEBD (polietileno de baixa 
densidade) e argila compactada pertencente a dois aterros de rejeitos perigosos do oeste dos EUA.

Os resultados dos ensaios para ambos os materiais estudados mostraram que os efeitos de umidade reduziram a resistência ao cisalhamento na interface. Também foi verificado que, para um mesmo valor de umidade, quanto maior o grau de compactação da argila, maior a resistência ao cisalhamento.

\section{$\underline{\text { Textura dos materiais sintéticos }}$}

Outro aspecto condicionante discutido por Bouazza (1996) foi a influência da textura do material sintético na resistência ao cisalhamento em interfaces. Para tal, foram realizados ensaios de cisalhamento direto de dimensões $100 \mathrm{~mm} \times 100 \mathrm{~mm}$ com solo argiloso e geomembrana de PVC com diferente textura. Os ensaios foram realizados sob condição seca, velocidade de cisalhamento na ordem de $0,1 \mathrm{~mm} / \mathrm{min}$, e carregamento normal variando de 100 a $400 \mathrm{kPa}$. Na Figura 2.4.6.2 é apresentado o resultado para diferentes geomembranas, uma lisa e outra rugosa, sob um mesmo carregamento normal.

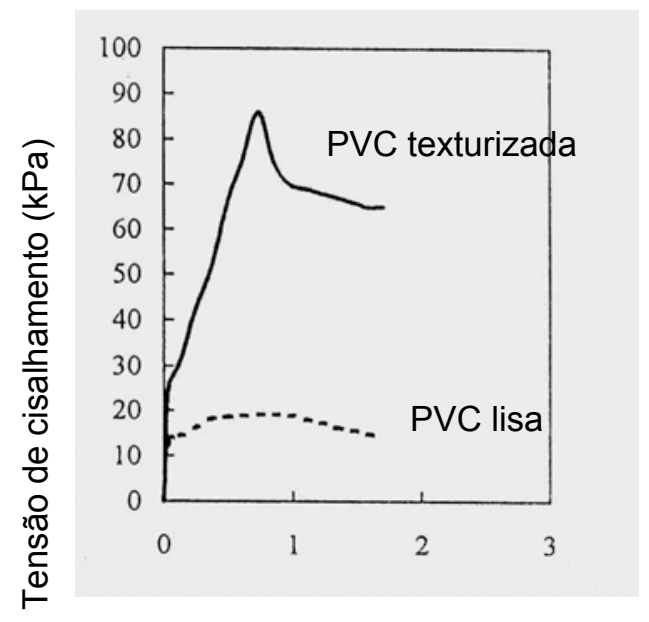

Deslocamento $(\mathrm{mm})$

Figura 2.4.6.2. Curva tensão cisalhante versus deslocamento para PVC lisa e texturizada dado a mesma tensão normal de 200kPa (BOUAZZA, 1996). 
Os resultados apresentados na figura acima indicaram que a rugosidade da geomembrana de PVC texturizada contribuiu para aumentar a resistência ao cisalhamento de interface, para uma mesma tensão normal constante.

Para os ensaios com variação de tensões normais, cujos resultados são apresentados na Figura 2.4.6.3, verificou-se que a geomembrana texturizada apresenta maior sensibilidade sobre os ângulos de atrito, variando de $69 \%$ a $86 \%$ para uma gama de tensões. Para a geomembrana de PVC lisa, observaram-se valores de ângulo de atrito muito baixos, em torno de $5^{\circ}$, independente da tensão normal aplicada.

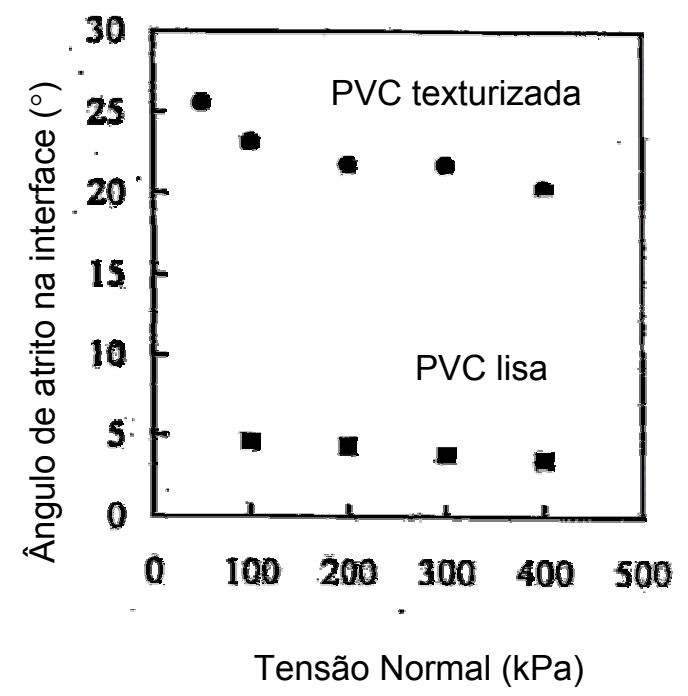

Figura 2.4.6.3. Variação do ângulo de atrito interno com tensão normal (BOUAZZA, 1996).

De acordo com Lee et al. (1998), o efeito da rugosidade da superfície da geomembrana apresenta um papel fundamental na resistência de cisalhamento em interfaces, observando-se o mesmo comportamento encontrado por Bouazza (1996). Isto é, observam-se maiores valores de resistências de cisalhamento mobilizadas na interface rugosa tanto para valores residuais quanto para valores de pico. 
Fishman \& Pal (1994) estudaram também o efeito da textura dos geossintéticos sob condições drenadas e não drenadas, variando a velocidade de deslocamento para simular tais condições.

Deste trabalho, pôde-se verificar que, para ambas as condições drenada e não drenada, a resistência ao cisalhamento na interface PEAD lisa/argila é menor que do que a resistência ao cisalhamento na interface PEAD texturizada/argila. Além disto, verificou-se que a resistência ao cisalhamento para interfaces lisas não se mostra sensível à velocidade de cisalhamento. Entretanto, para interfaces PEAD texturizada/argila, o comportamento de cisalhamento é influenciado pela velocidade de deslocamento, observando-se que, para baixas velocidades (condições drenadas), a resistência ao cisalhamento é menor do que as obtidas para elevadas velocidades de cisalhamento (condições não drenadas). Este aumento de resistência pode ser explicado pela tendência de dilatação durante o cisalhamento não drenado que induz pressões neutras negativas, o que resulta no aumento da resistência próximo à interface.

Orman (1994) verificou o efeito da textura das geomembranas em contato com materiais granulares e siltosos. A partir de uma série de ensaios de cisalhamento direto com solos coesivos e granulares com geomembranas de PEAD, pode-se concluir que as geomembranas rugosas apresentaram maiores valores de ângulos de atrito em contato com materiais de granulometria fina. Estes últimos são capazes de se entrosarem totalmente com a geomembranas devido à relação entre os tamanhos das partículas e a altura texturizada. Contudo, os materiais de granulometria grossa tendem a deslizarem sobre a textura, apresentando características de atrito semelhantes com geomembranas lisas e rugosas.

\section{Influência dos líquidos percolados}

Masada et al. (1994), através de uma série de ensaios de cisalhamento direto investigaram a influência dos líquidos percolados na resistência ao cisalhamento em interfaces de liners para simular as possíveis condições in situ em um aterro sanitário. O programa do experimento 
desenvolvido consistiu em duas séries de ensaios: a primeira, onde se realizaram ensaios de cisalhamento sob condição não saturada; e a segunda série, consistindo-se de ensaios adicionais com várias combinações de saturação dos corpos de prova.

Com base nos resultados acima, Masada et al. (1994) concluíram que os ângulos de atrito obtidos nos ensaios com saturação com água são menores dos que os obtidos pela saturação com percolados. Nos ensaios inundados com percolados, observou-se aumento na coesão para interfaces argila/geomembrana lisa, enquanto para interfaces argila/geomembrana texturizada verificou-se um pequeno decréscimo.

Tabela 2.4.6.4. Resumo dos resultados dos ensaios com geomembranas sem envelhecimento.

\begin{tabular}{lcc}
\hline \multicolumn{1}{c}{ Tipo de interface } & $\phi$ ou $\delta\left(^{\circ}\right)$ & C ou Ca (kPa) \\
\hline & Condição não saturada & 113.7 \\
\hline Argila (interno) & $27.8^{\circ}$ & 12.5 \\
Argila -PEAD lisa & $17.1^{\circ}$ & 19.4 \\
Argila - PEAD texturizada & $24.2^{\circ}$ & 14.3 \\
Argila - PVC lisa & $17.5^{\circ}$ & \\
\hline & Condição saturada com água & 48.8 \\
\hline Argila (interno) & $21.2^{\circ}$ & 3.2 \\
Argila -PEAD lisa & $12.2^{\circ}$ & 12.6 \\
Argila-PEAD texturizada & $19.7^{\circ}$ & 5.0 \\
Argila - PVC lisa & $13.7^{\circ}$ & 46.8 \\
\hline & Condição saturada com percolados & 14.3 \\
\hline Argila (interno) & $25.5^{\circ}$ & 12.0 \\
Argila -PEAD lisa & $13.4^{\circ}$ & 16.4 \\
Argila - PEAD texturizada & $22.6^{\circ}$ & $14.45^{\circ}$ \\
Argila - PVC lisa &
\end{tabular}

Fonte: Masada et al. (1994)

Masada et al. (1994) também verificaram o efeito do envelhecimento das geomembranas devido à percolação de chorume em aterros sanitários na resistência ao cisalhamento nas interfaces. Os 
resultados são apresentados na Tabela 2.4.6.5. Observa-se uma tendência de decréscimo de resistência e aumento de coesão com o envelhecimento da geomembrana nos ensaios realizados sob condição não saturada. De outro modo, nos ensaios realizados sob condição saturada com percolados, observa-se, em geral, um aumento no ângulo de atrito e uma diminuição na coesão.

Tabela 2.4.6.5. Resultados dos ensaios com geomembranas expostas a percolados durante 7 e 30 dias.

\begin{tabular}{|c|c|c|}
\hline Tipo de interface & $\phi$ ou $\delta\left(^{\circ}\right)$ & $\mathrm{C}$ ou Ca (kPa) \\
\hline \multicolumn{3}{|c|}{ Exposição durante 7 dias } \\
\hline \multicolumn{3}{|l|}{ Condição não saturada } \\
\hline Argila (interno) & $27.8^{\circ}$ & 113.7 \\
\hline Argila -PEAD lisa & 17.8 & 12.5 \\
\hline Argila - PEAD texturizada & 25.8 & 27.4 \\
\hline Argila - PVC lisa & 12.3 & 18.2 \\
\hline \multicolumn{3}{|c|}{ Condição saturada com percolados } \\
\hline Argila (interno) & $25.5^{\circ}$ & 46.8 \\
\hline Argila -PEAD lisa & 15.0 & 5.1 \\
\hline Argila - PEAD texturizada & 21.6 & 7.8 \\
\hline Argila - PVC lisa & 10.0 & 14.1 \\
\hline \multicolumn{3}{|c|}{ Exposição durante 30 dias } \\
\hline \multicolumn{3}{|l|}{ Condição não saturada } \\
\hline Argila (interno) & $27.8^{\circ}$ & 113.7 \\
\hline Argila -PEAD lisa & 13.8 & 15.9 \\
\hline Argila - PEAD texturizada & 20.7 & 25.0 \\
\hline Argila - PVC lisa & 10.0 & 19.0 \\
\hline \multicolumn{3}{|c|}{ Condição saturada com percolados } \\
\hline Argila (interno) & $25.5^{\circ}$ & 46.8 \\
\hline Argila -PEAD lisa & 15.2 & 1.8 \\
\hline Argila - PEAD texturizada & 20.8 & 4.3 \\
\hline Argila - PVC lisa & 8.2 & 13.4 \\
\hline
\end{tabular}




\section{Influência do efeito escala}

De acordo com a ASTM D-5321, o ensaio para cisalhamento direto envolvendo interfaces entre solos e geossintéticos deve apresentar caixas de dimensões mínimas de $300 \mathrm{~mm} \times 300 \mathrm{~mm}$.

Entretanto, em função de alguns aspectos como custo do equipamento e dificuldades de compactação, grande parte dos ensaios envolvendo geossintéticos tem sido realizado em caixas de menores dimensões. Por causa dos diferentes valores encontrados, o efeito escala tem sido estudado por diversos pesquisadores.

Para investigar tal efeito, Hsieh et al. (2002) realizaram ensaios de cisalhamento direto envolvendo geomembranas de PEAD-polietileno de alta densidade- com diferentes níveis de rugosidade, e dois tipos de areias. Vários tamanhos de caixas foram utilizados no estudo, com dimensões de $100 \times 100 \mathrm{~mm}, 200 \times 200 \mathrm{~mm}, 300 \times 300 \mathrm{~mm}$ e $400 \times 400 \mathrm{~mm}$.

De acordo com os resultados, verificou-se que os valores de ângulos de atrito de pico obtidos nas caixas de pequenas dimensões são menores do que os obtidos nas caixas de grandes deslocamentos. Contudo, os valores residuais são maiores, devido ao efeito escala, que limita os deslocamentos por cisalhamento.

Por outro lado, observaram-se valores de atrito de pico maiores e semelhantes a partir das caixas de dimensões $300 \times 300 \mathrm{~mm}$ e 400x400 mm. Isto porque as caixas de grandes dimensões eliminam o efeito de borda. Tais resultados são apresentados na Tabela 2.4.6.6.

Tabela 2.4.6.6. Resumo dos ângulos de atrito entre geomembrana de PEAD lisa e areia para vários tamanhos de caixas de cisalhamento com base.

\begin{tabular}{ccc}
\hline Tamanho da caixa & Ângulo de atrito de pico & Ângulo de atrito residual \\
\hline $100 \times 100 \mathrm{~mm}$ & 19.70 & 17.90 \\
$200 \times 200 \mathrm{~mm}$ & $22.4^{\circ}$ & $16.0^{\circ}$ \\
$300 \times 300 \mathrm{~mm}$ & $24.2^{\circ}$ & 18.90 \\
$400 \times 400 \mathrm{~mm}$ & $24.1^{\circ}$ & $19.10^{\circ}$ \\
\hline
\end{tabular}

Fonte: Hsieh et al. (2002). 


\section{MATERIAIS E MÉTODOS}

\subsection{MATERIAIS UTILIZADOS}

Neste trabalho foram utilizados dois solos, um arenoso e outro de características argilosas, assim identificados:

- Amostra $01 \rightarrow$ areia grossa a média (Laboratório) constituída de grãos sub-angulares a angulares;

- Amostra $02 \rightarrow$ argila siltosa pouco arenosa (solo do aterro sanitário de Piracicaba - SP).

Foram empregados cinco tipos de geomembranas:

- PVC (polivinil clorado)- 1,0mm de espessura;

- PEAD (polietileno de alta densidade) lisa- 1,0mm de espessura;

- PELMD (polietileno linear de média densidade) lisa- 0,5mm de espessura;

- PEAD texturizada A-2,0mm de espessura;

- $\quad$ PEAD texturizada AR-2,5mm de espessura.

Os termos A e AR foram utilizados para designar os diferentes tipos de rugosidade das geomembranas. A Figura 3.1.1 mostra a diferença entre as superfícies das geomembranas utilizadas. 


\title{
PEAD
}

\author{
PE \\ linear
}

\section{PVC}

\section{PEAD}

AR

\section{PEAD}

A

Figura 3.1.1. Geomembranas utilizadas.

\subsection{CARACTERIZAÇÃO DAS AMOSTRAS}

$\mathrm{Na}$ Tabela 3.2.1 são apresentados os ensaios realizados para caracterização das amostras de solo e suas respectivas normas e/ou metodologias. Os ângulos de atrito internos de ambos os solos foram determinados através de ensaios de cisalhamento direto e ring shear, seguindo-se os procedimentos recomendados por Head (1994).

Para caracterização das geomembranas foram realizados ensaios de tração de acordo com as especificações da American Society for Testing and Materials (ASTM). Nas geomembranas com espessura maior que um milímetro foi adotada a norma D638-96, e nas com espessura menor que um milímetro, foi adotada a D 882-95a. Para cada geomembrana foram utilizados cinco corpos de prova em cada sentido (longitudinal e transversal), totalizando dez amostras. 
Tabela 3.2.1- Métodos utilizados nos ensaios de caracterização e de compactação dos solos.

\begin{tabular}{lcc}
\hline Ensaio & Amostra & Norma \\
\hline Análise granulométrica & $01 / 02$ & NBR 7181-MB 32 \\
Limites de consistência & 02 & NBR 6459-MB 30 \\
Peso específico dos sólidos & 02 & NBR 9180-MB 31 \\
Ensaio de compactação- Proctor Normal & 02 & NBR 6508 \\
Índices de vazios máximo e mínimo & 01 & MB-3324 e MB-3328 \\
\hline
\end{tabular}

\subsection{ENSAIO DE RING SHEAR}

\subsubsection{Descrição do Programa Experimental}

Para a determinação da resistência de interfaces envolvendo as amostras e geomembranas apresentadas no item 3.1, o programa experimental foi dividido em quatro estágios e executado através de ensaios de ring shear.

O primeiro e segundo estágios se referem ao material granular. No primeiro estágio, ambos os materiais foram ensaiados em condição seca ao ar. O segundo estágio diferencia-se do primeiro por apresentar os materiais em condição saturada. O objetivo deste estágio foi o de simular uma condição ambiental particular na qual ocorre umidade devido à percolação do chorume. Neste ensaio, o material granular foi moldado apenas no estado mínimo de compacidade, a título de comparação. O carregamento normal aplicado variou entre 25 e 200kPa. Os ensaios foram realizados em condição drenada, com velocidade angular de 1,80 graus/min, o que corresponde a uma velocidade linear de aproximadamente $0,981 \mathrm{~mm} / \mathrm{min}$. Para o cálculo da velocidade angular, admitiu-se um rádio médio equivalente a $62,5 \mathrm{~mm}$.

Por sua vez, o terceiro estágio consistiu em ensaiar os solos argilosos com GC igual a 98\% ( $\left.\gamma d=15,6 \mathrm{kN} / \mathrm{m}^{3}\right)$. Neste estágio, o material foi compactado na umidade ótima $(26,7 \%)$ e realizado sob condição inundada e não inundada, com o intuito de verificar o efeito da inundação na resistência de interface. Ambas as condições de ensaios foram realizadas com adensamento da amostra sob a tensão normal de interesse e cisalhamento com velocidade de 3,0 graus/minuto $(1,635 \mathrm{~mm} /$ minutos $)$, tentando representar uma ruptura 
não drenada, de forma a simular a condição mais crítica. Os carregamentos verticais aplicados foram 25kPa, 100kPa e 200kPa. Para os ensaios inundados, concomitantemente à aplicação da tensão normal, realizou-se a inundação do corpo de prova com água destilada durante um período de aproximadamente 14 horas. Foram realizadas leituras de deslocamentos verticais ao longo do tempo até a estabilização do adensamento.

No quarto estágio, os corpos de prova foram compactados com GC igual a $85 \%\left(\gamma_{d}=13,5 \mathrm{kN} / \mathrm{m}^{3}\right)$, na umidade ótima e realizados sob condição inundada e não inundada. Os ensaios também foram realizados tentando simular uma ruptura não drenada e com mesma velocidade de cisalhamento (3,0 graus/minuto). Os carregamentos aplicados foram $25 \mathrm{kPa}, 100 \mathrm{kPa} e$ 200kPa. Também foram realizados alguns ensaios de interface com material moldado na umidade acima da ótima ( $w=28,7 \%)$, e realizados sob condição inundada e não inundada.

\subsubsection{Descrição do Ensaio}

De acordo com Head (1994), o ensaio de ring shear foi desenvolvido com a finalidade inicial de estimar as resistências residuais de solos argilosos, sendo posteriormente modificado e utilizado com outros materiais.

No equipamento modificado proposto por Bromhead (1979), o anel apresenta diâmetros externo e interno de $100 \mathrm{~mm}$ e $70 \mathrm{~mm}$, respectivamente, e profundidade de $5 \mathrm{~mm}$. Tal ensaio destaca-se por permitir a continuidade dos deslocamentos por cisalhamento até que se atinja a condição residual. Além desta característica, apresenta outras vantagens como a presença de área constante e maior controle das condições de compactação, devido às pequenas dimensões.

Neste ensaio, uma pequena amostra de solo é confinada radialmente entre anéis concêntricos, e verticalmente entre uma placa porosa e um anel superior, o qual transmite o carregamento vertical aplicado à amostra. O sistema de carregamento apresenta braço de alavanca na proporção 10:1. O compartimento que contém a amostra pode ser submerso em água durante o ensaio. Uma rotação é imposta ao anel inferior enquanto o anel superior é impedido de rotacionar através de um par de anéis dinamométricos, que permitem a determinação do torque transmitido à 
amostra. Durante o ensaio são medidos deslocamento angular, força e deslocamento vertical.

Contudo, um aspecto prático que deve ser verificado é a relação entre a altura do anel e o diâmetro máximo das partículas do solo, a qual deve estar entre cinco e seis. Como o anel original não atendia a esta relação, em virtude do tamanho máximo dos grãos de areia, tornou-se necessário a construção de outro anel com altura apropriada. As dimensões obtidas foram: diâmetro externo, $100 \mathrm{~mm}$; diâmetro interno, $25 \mathrm{~mm}$ e espessura, $12 \mathrm{~mm}$. A Figura 3.3.2.1 mostra a comparação entre o anel original e o modificado e a Figura 3.3.2.2 apresenta os detalhes.

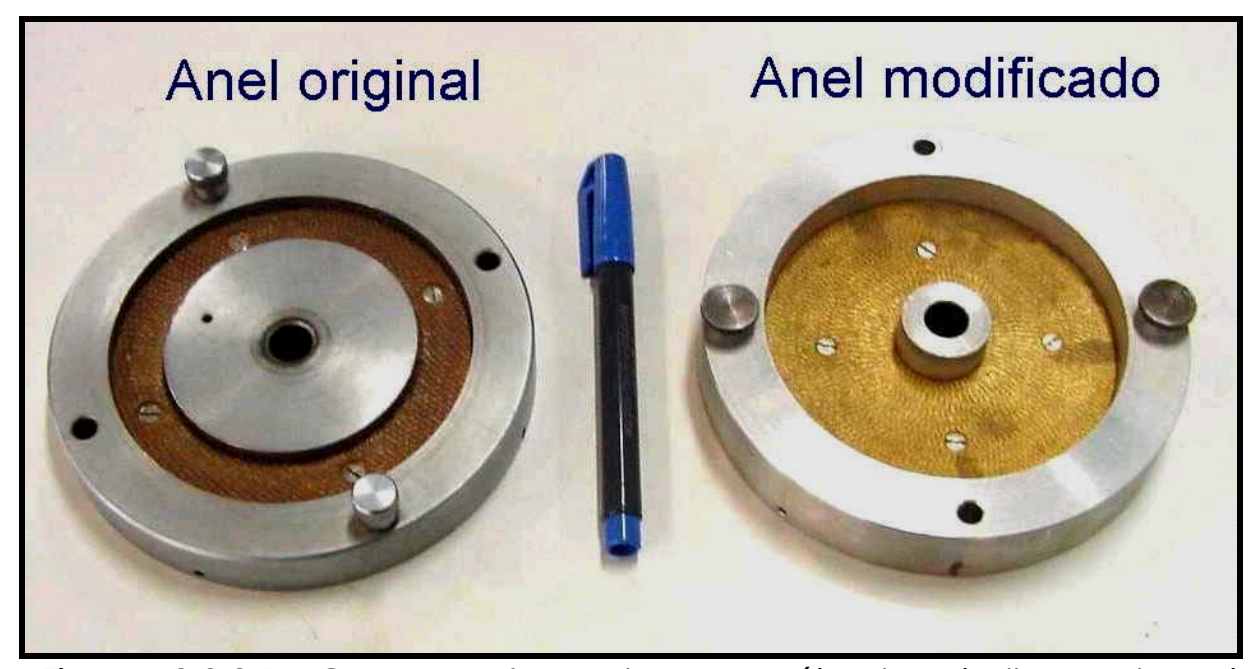
modificado.

Figura 3.3.2.1. Comparação ente os anéis de cisalhamento original e 


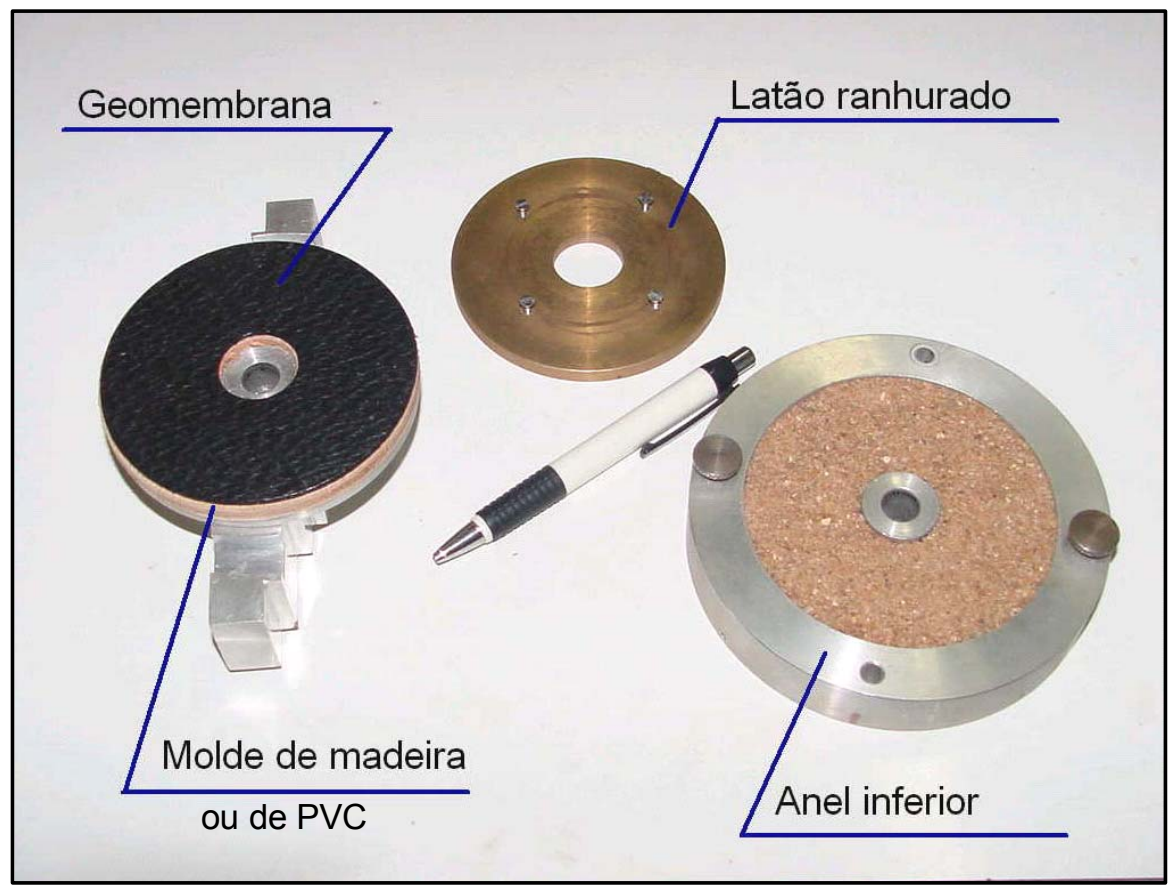

Figura 3.3.2.2. Detalhes do anel modificado.

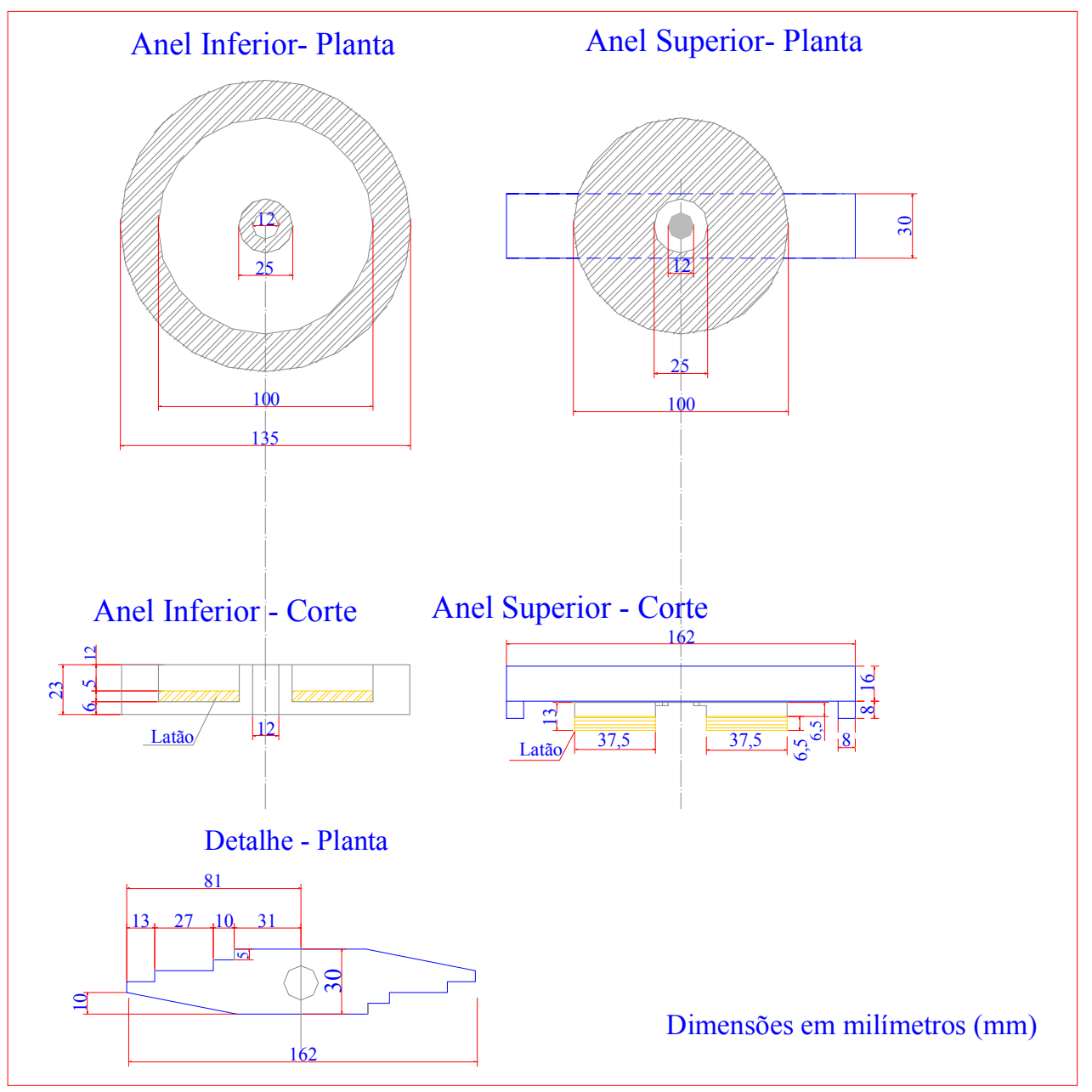

Figura 3.3.2.3. Esquema do anel modificado. 

completo.

Na Figura 3.3.2.4 é apresentado o equipamento de ring shear

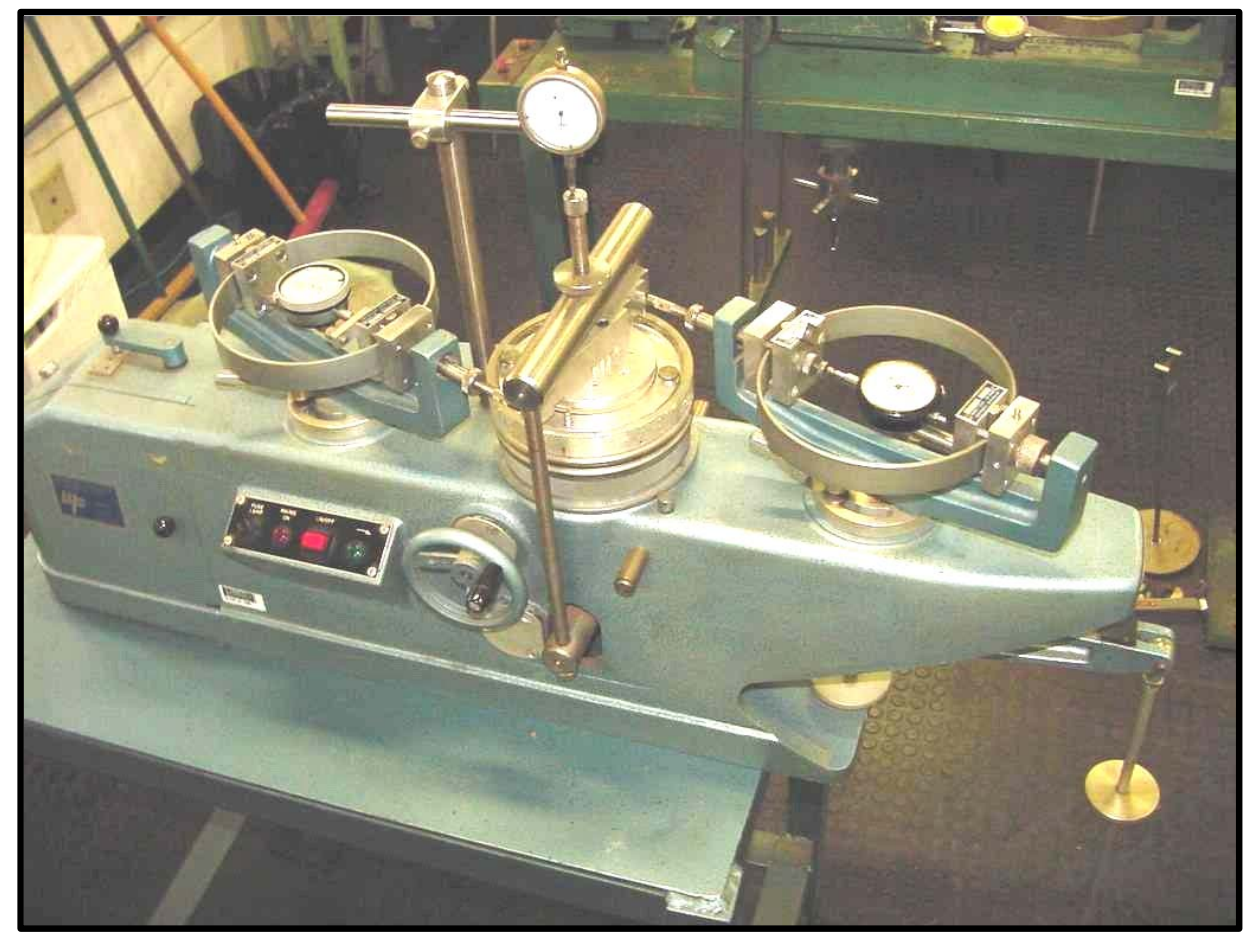

Figura 3.3.2.4. Equipamento- Ring Shear.

De acordo com Bromhead (1979), a tensão normal $(\sigma)$ aplicada a amostra é expressa pela Equação 1:

$$
\sigma=\frac{P}{\pi\left(R_{2}^{2}-R_{1}^{2}\right)}
$$

Onde P- carregamento vertical aplicado;

$R_{2}$ e $R_{1}$ - raios externos e internos, respectivamente.

Para o ensaio, adota-se convencionalmente uma distribuição de tensão cisalhante atuando uniformemente sobre a amostra. O torque (T) transmitido à amostra é dado por:

$$
T=\frac{2}{3} \pi\left(R_{2}^{3}-R_{1}^{3}\right) \tau
$$

Onde $\tau \rightarrow$ tensão cisalhante. 
O torque aplicado é calculado por meio da carga média multiplicada pela distância entre eles. Deste modo, tem-se:

$$
T=\left(F_{1}+F_{2}\right) L / 2
$$

Onde $\mathrm{F} 1$ e $\mathrm{F} 2 \rightarrow$ forças medidas pelos anéis dinamométricos.

Logo, tem-se que a tensão cisalhante é dada por:

$$
\tau=\frac{3\left(F_{1}+F_{2}\right) L}{4 \pi\left(R_{2}^{3}-R_{1}^{3}\right)}
$$

O ângulo de atrito $(\delta)$ é definido como a relação entre a tensão cisalhante de pico e/ou residual pela tensão normal aplicada, conforme Equação 5.

$$
\delta_{p, r}=\operatorname{arctg}\left(\frac{\tau_{p, r}}{\sigma}\right)
$$

\subsubsection{Moldagem dos corpos de prova}

A moldagem dos corpos de prova seguiu o recomendado por Head (1994). Nos materiais granulares a moldagem foi realizada de forma a simular as condições de densidade mínima (CR=0\%, $\gamma_{d}=14,6 \mathrm{kN} / \mathrm{m}^{3} ; \mathrm{e}=0,83$ ), média $\left(C R=57 \% ; \gamma_{d}=16,0 \mathrm{kN} / \mathrm{m}^{3} ; e=0,68\right)$ e máxima $\left(C R=100 \% ; \gamma_{d}=17,4 \mathrm{kN} / \mathrm{m}^{3} ; e=0,53\right)$ do material granular. A densidade mínima foi obtida despejando-se o material no anel com o auxílio de um funil e mantendo-se uma altura constante de aproximadamente $1 \mathrm{~cm}$. Por sua vez, a densidade máxima foi conseguida com a vibração do material em três camadas através da mesa vibratória comum e sobrecarga. A condição de compacidade intermediária foi controlada pelo lançamento do material em duas camadas, seguido de leve vibração.

Quanto à moldagem do solo argiloso, realizou-se a compactação por prensagem, dentro de uma faixa de umidade e peso específico seco préestabelecidos. O controle de compactação fez-se através da pesagem do material antes e depois da prensagem, para verificação do peso específico 
seco. A umidade do solo compactado foi controlada através da obtenção de três medidas de umidade. Após cada ensaio de cisalhamento, averiguou-se também a umidade final do solo argiloso.

\subsubsection{Fixação das geomembranas}

Para a fixação dos geossintéticos, foram construídos moldes circulares de madeira com dimensões adequadas ao anel. Adicionalmente, utilizou-se uma fita transferível de dupla face Scotch YR-9767 de fabricação da $3 M^{\circledR}$ para a aderência do polímero nos moldes. A técnica consiste em aplicar a fita em um dos materiais (madeira ou geossintético), para posterior junção dos dois. Seguindo-se as recomendações do fabricante, respeitou-se o tempo de cura mínimo de aproximadamente 24 horas. Para os ensaios realizados sob imersão foram empregados moldes de PVC para a fixação dos geossintéticos, e utilizado o adesivo epóxi Araldite®. Tal procedimento foi adotado em função do desprendimento da fita sob ação da água, e da possibilidade de alteração dos dados volumétricos por causa do inchamento da madeira.

\subsection{Ensaios de cisalhamento direto}

A título de comparação foram realizados ensaios de cisalhamento direto com algumas das interfaces analisadas por meio do ring shear. Devido à limitação de $10 \mathrm{~mm}$ de deslocamentos nas caixas de cisalhamento direto de 100x100mm, empregou-se uma base maior para a fixação das geomembranas de forma que fossem possíveis deslocamentos de até $20 \mathrm{~mm}$. Alterou-se também a configuração do ensaio, onde a geomembrana foi colocada na base inferior e o solo na parte superior.

Para as interfaces com solo arenoso, os ensaios foram realizados na condição seca e o material foi moldado em sua compacidade mínima (CR=0\%). Os ensaios foram realizados em condição drenada e com velocidade de $0,5 \mathrm{~mm} / \mathrm{min}$ de forma a simular as mesmas condições impostas no ring shear. Os carregamentos normais aplicados foram $30 \mathrm{kPa}, 54 \mathrm{kPa} e$ $113 \mathrm{kPa}$ para as interfaces com geomembranas de PVC, PEAD A e PEAD AR. 
Paras interfaces com geomembranas de PEAD lisa e PELMD foram aplicados carregamentos de $30 \mathrm{kPa}, 65 \mathrm{kPa}$ e $113 \mathrm{kPa}$.

Quanto aos solos argilosos, foram analisadas três diferentes interfaces, definidas assim:

\begin{tabular}{lccc}
\hline Interface & Geomembrana & Condição do ensaio & Umidade inicial \\
\hline I & PEAD AR & Não inundado & $26,7 \%$ \\
II & PEAD AR & Inundado & $26,7 \%$ \\
III & PEAD lisa & Inundado & $28,7 \%$ \\
\hline
\end{tabular}

A velocidade de cisalhamento aplicada nos ensaios de interface geomembrana/argila e de determinação do atrito interno da argila foi $0,5 \mathrm{~mm} / \mathrm{min}$ e os carregamentos normais foram $25 \mathrm{kPa}, 50 \mathrm{kPa}$ e $150 \mathrm{kPa}$. 


\section{APRESENTAÇÃO E ANÁLISE DOS RESULTADOS}

\subsection{ENSAIOS DE CARACTERIZAÇÃO}

\subsubsection{Material granular}

A curva granulométrica do material granular, obtida por peneiramento de acordo com a NBR 7181-MB-32, é apresentada na Figura 4.1.1.1.

As propriedades e classificação deste material, obtidos a partir da curva, assim como os índices de vazios máximos e mínimos, determinados pelos métodos brasileiros MB-3324 e MB-3328, são apresentados na Tabela 4.1.1.1.

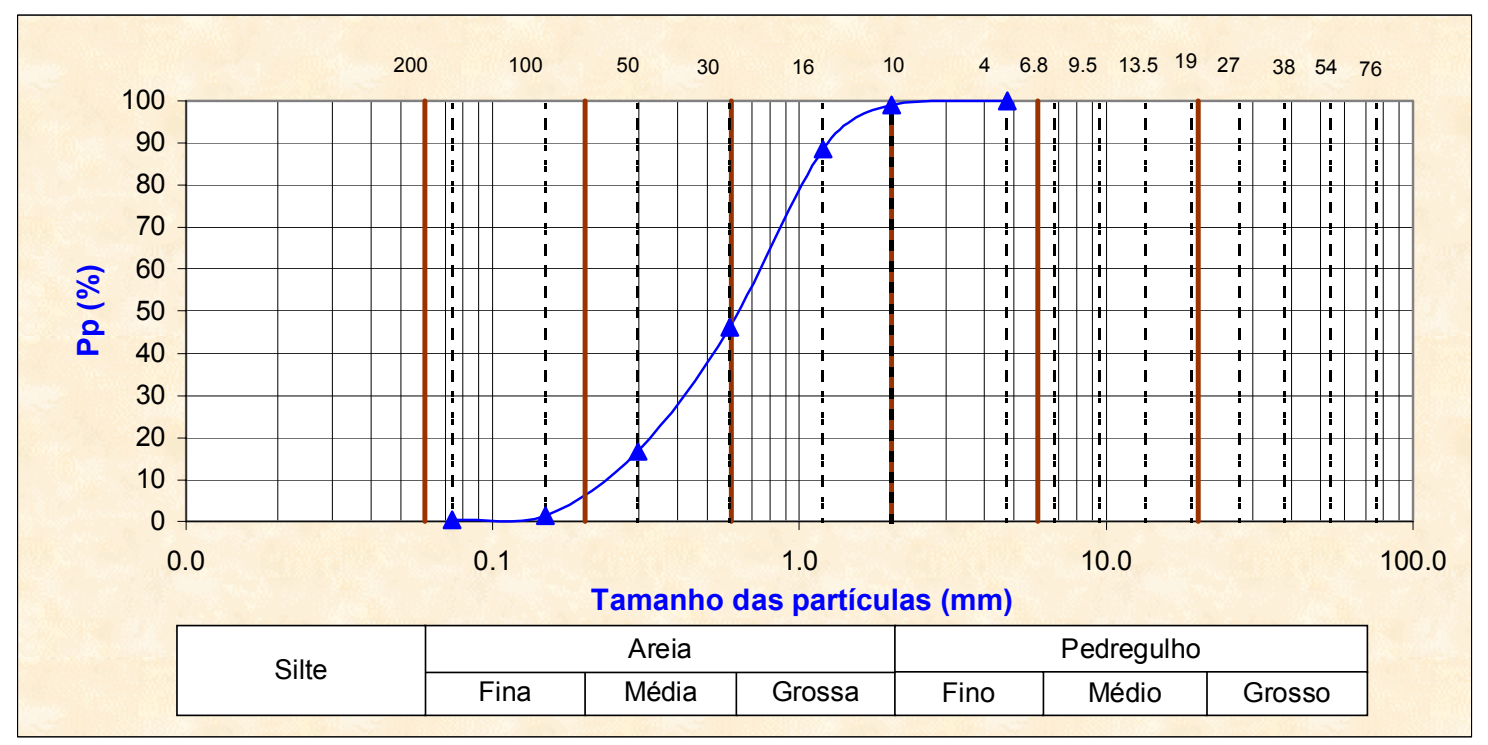

Figura 4.1.1.1. Curva granulométrica da areia. 
Tabela 4.1.1.1. Propriedades do material granular utilizado nos ensaios.

\begin{tabular}{lc}
\hline Propriedades & \\
\hline$D_{10}(\mathrm{~mm})$ & 0,23 \\
$D_{30}(\mathrm{~mm})$ & 0,42 \\
$D_{60}(\mathrm{~mm})$ & 0,78 \\
Coeficiente de uniformidade, Cu & 3,4 \\
Coeficiente de curvatura $C_{v}$ & 1,00 \\
Classificação do solo & $\mathrm{SP}$ \\
Peso específico dos sólidos, $\gamma \mathrm{s}$ & $26,7 \mathrm{kN} / \mathrm{m}^{3}$ \\
Peso específico seco mínimo, $\gamma$ d Mínimo & $14,6 \mathrm{kN} / \mathrm{m}^{3}$ \\
Peso específico seco máximo, $\gamma \mathrm{d}$ Máximo & $17,4 \mathrm{kN} / \mathrm{m}^{3}$ \\
Índice de vazios mínimo, e min & 0,53 \\
Índice de vazios máximo, e max & 0,83 \\
\hline
\end{tabular}

As propriedades de resistência dos materiais granulares foram determinadas por meio de ensaios de cisalhamento direto e de ring shear. Os gráficos de tensão cisalhante e de deformação volumétrica versus deslocamentos, obtidos por cisalhamento direto, são apresentados nas Figuras 4.1.1.2, 4.1.1.3 e 4.1.1.4.
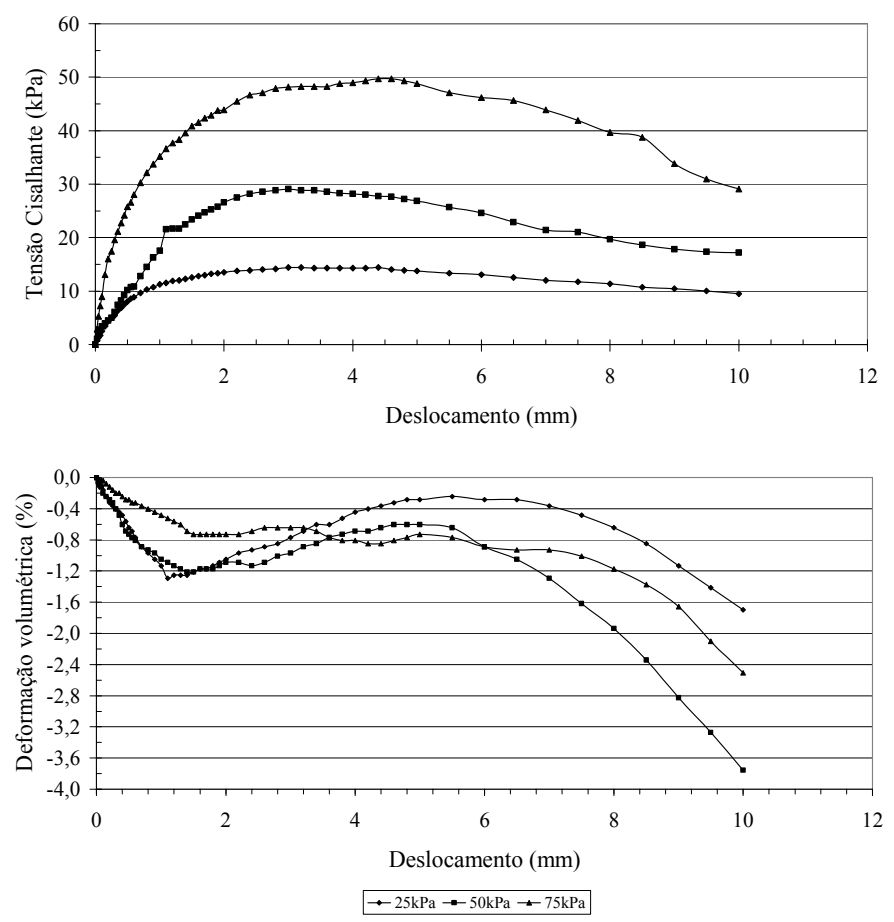

Figura 4.1.1.2. Resultados dos ensaios de cisalhamento direto em areia$\mathrm{CR}=0 \%$. 

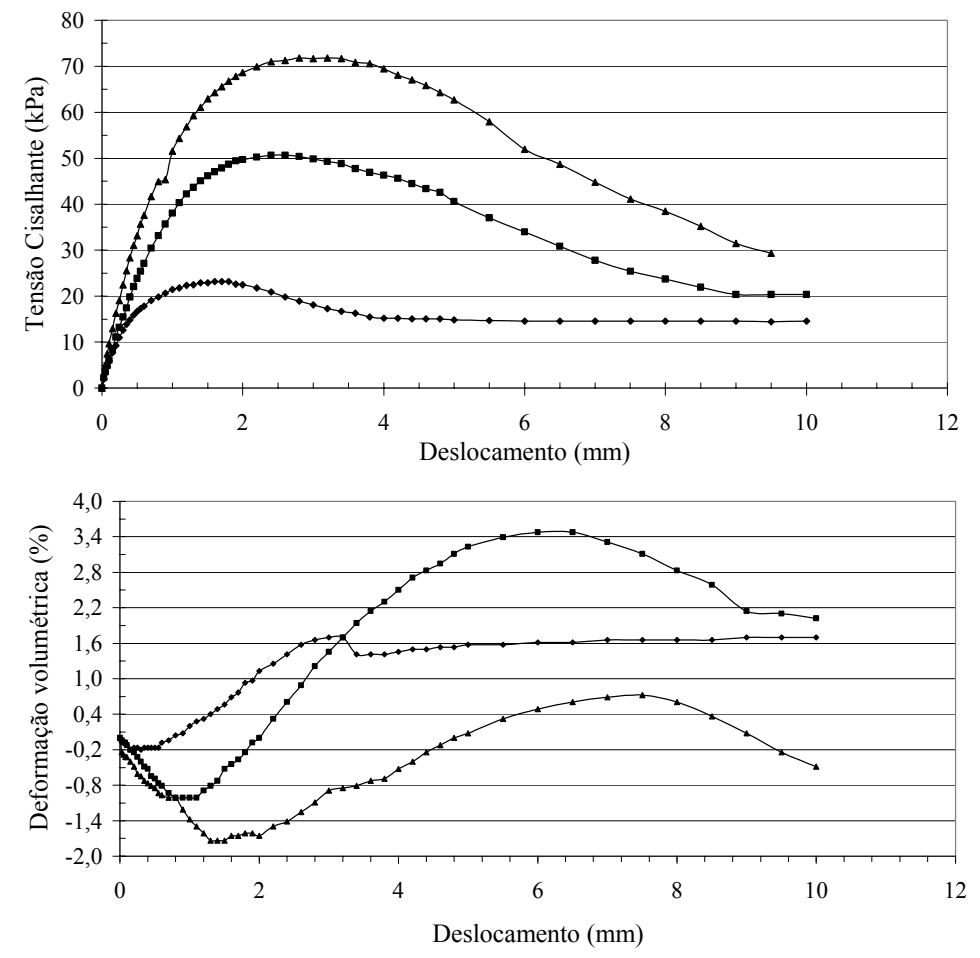

$\rightarrow 25 \mathrm{kPa} \rightarrow 50 \mathrm{kPa} \rightarrow 75 \mathrm{kPa}$

Figura 4.1.1.3. Resultados dos ensaios de cisalhamento direto em areia$C R=57 \%$.
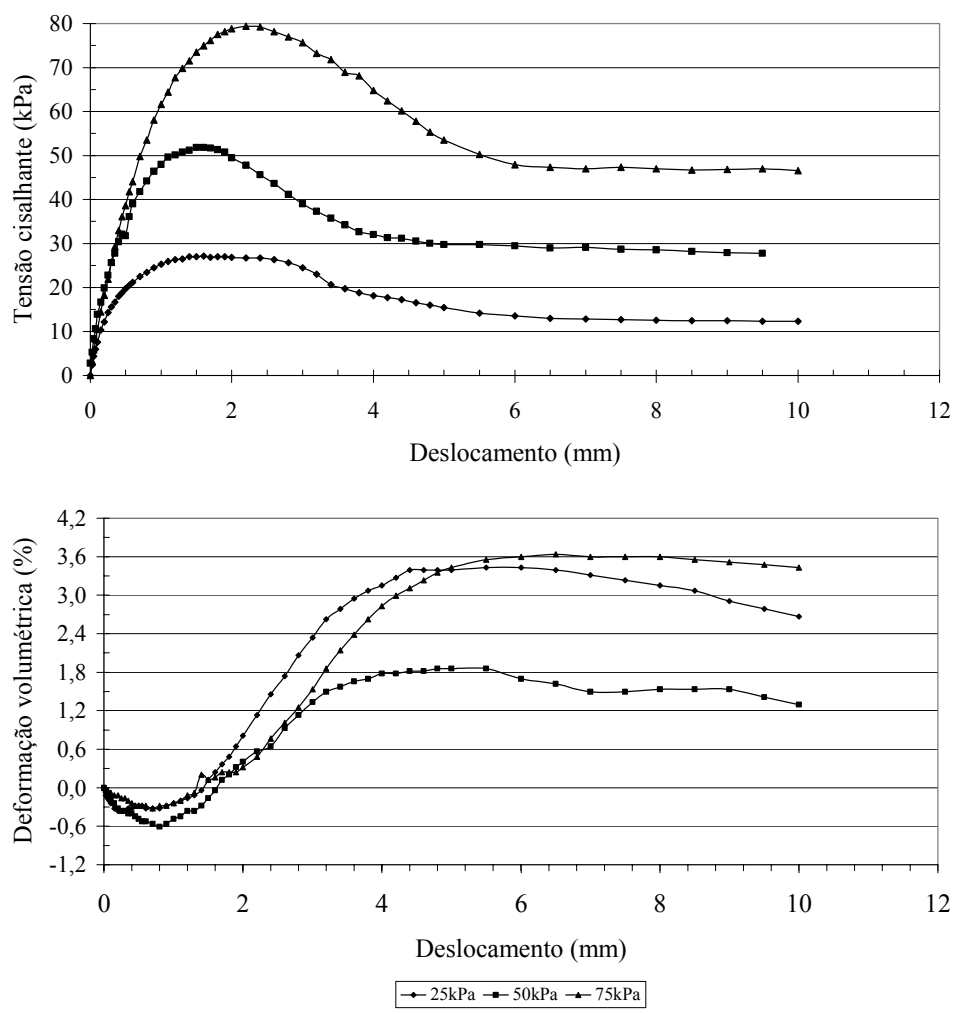

Figura 4.1.1.4. Resultados dos ensaios de cisalhamento direto em areia$C R=100 \%$. 
As envoltórias de resistência obtidas, a partir destes resultados, são apresentadas na Figura 4.1.1.5.

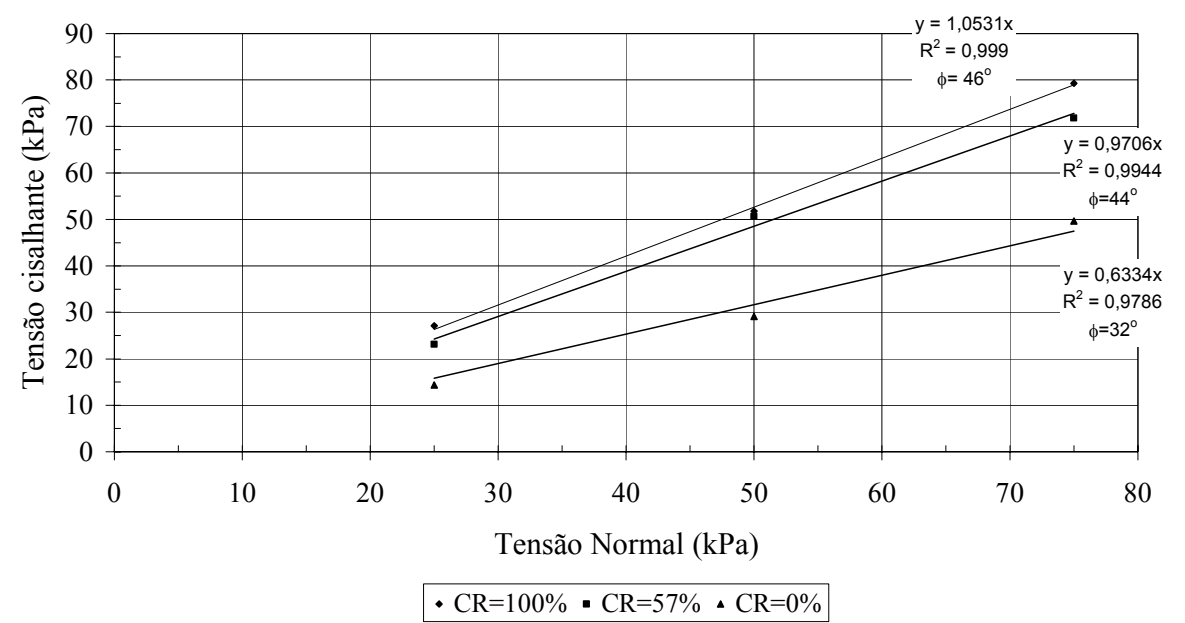

Figura 4.1.1.5. Envoltória de resistência- Cisalhamento direto.

Nas Figuras 4.1.1.6, 4.1.1.7 e 4.1.1.8 são apresentadas as curvas de tensão cisalhante versus deslocamento obtidas através dos ensaios de ring shear.
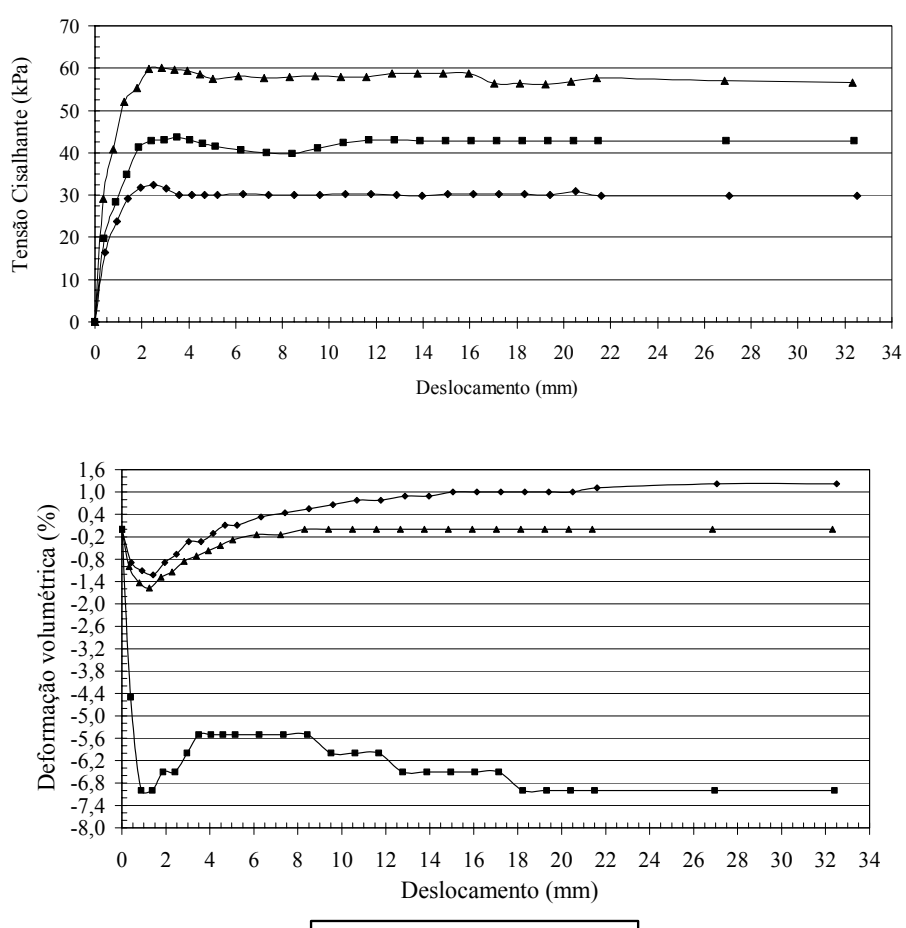

$\rightarrow-54 \mathrm{kPa} \rightarrow-81 \mathrm{kPa} \quad \leftarrow 109 \mathrm{kPa}$

Figura 4.1.1.6. Resultados dos ensaios de ring shear em areia- $C R=0 \%$. 

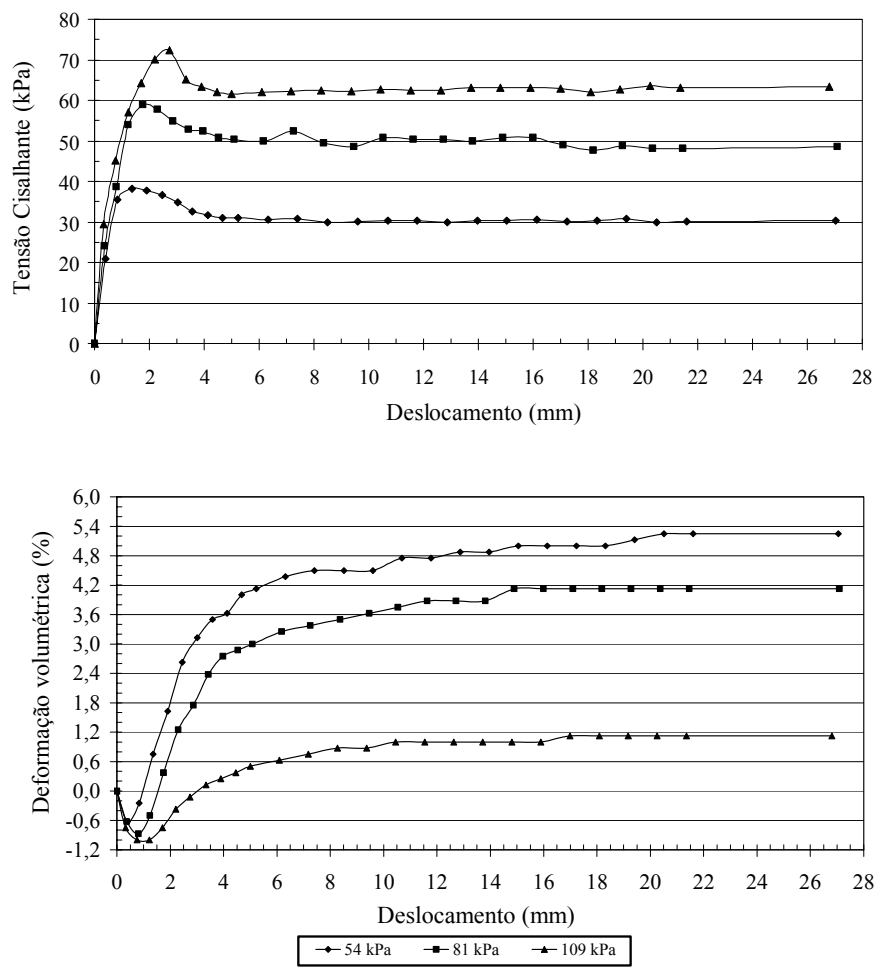

Figura 4.1.1.7. Resultados dos ensaios de ring shear em areia $C R=57 \%$.
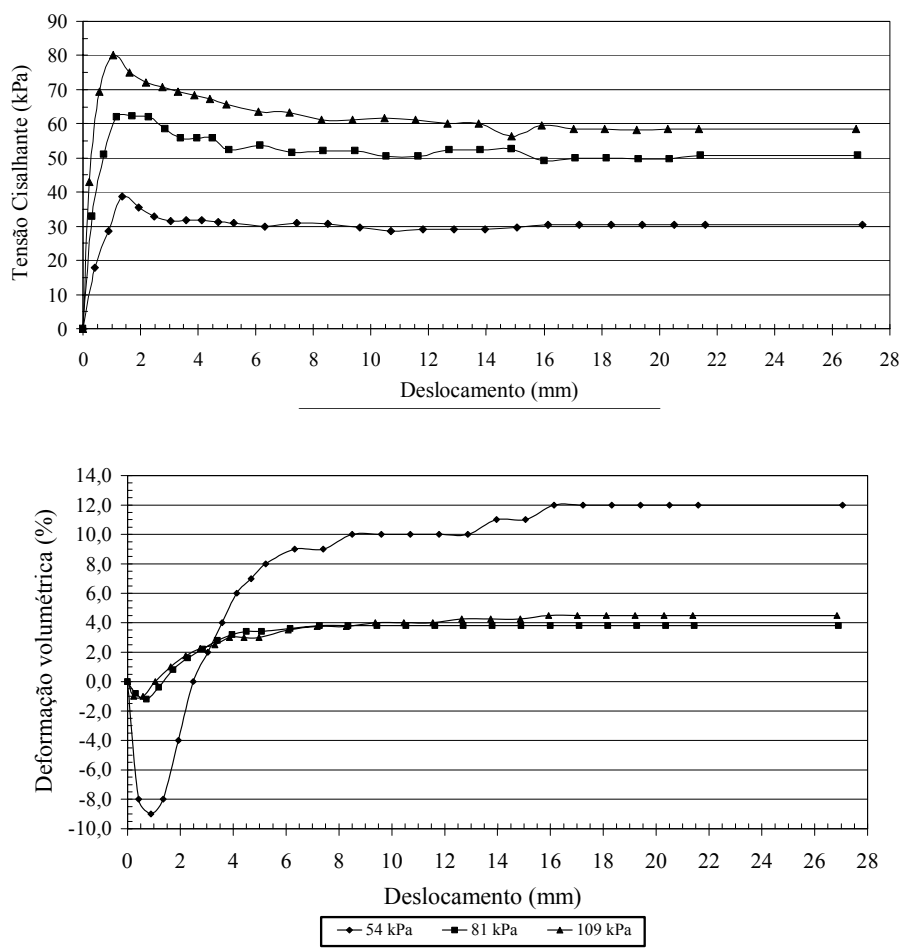

Figura 4.1.1.8. Resultados dos ensaios de ring shear em areia- $C R=100 \%$.

As envoltórias de resistência obtidas são apresentadas na Figura 4.1.1.9. 


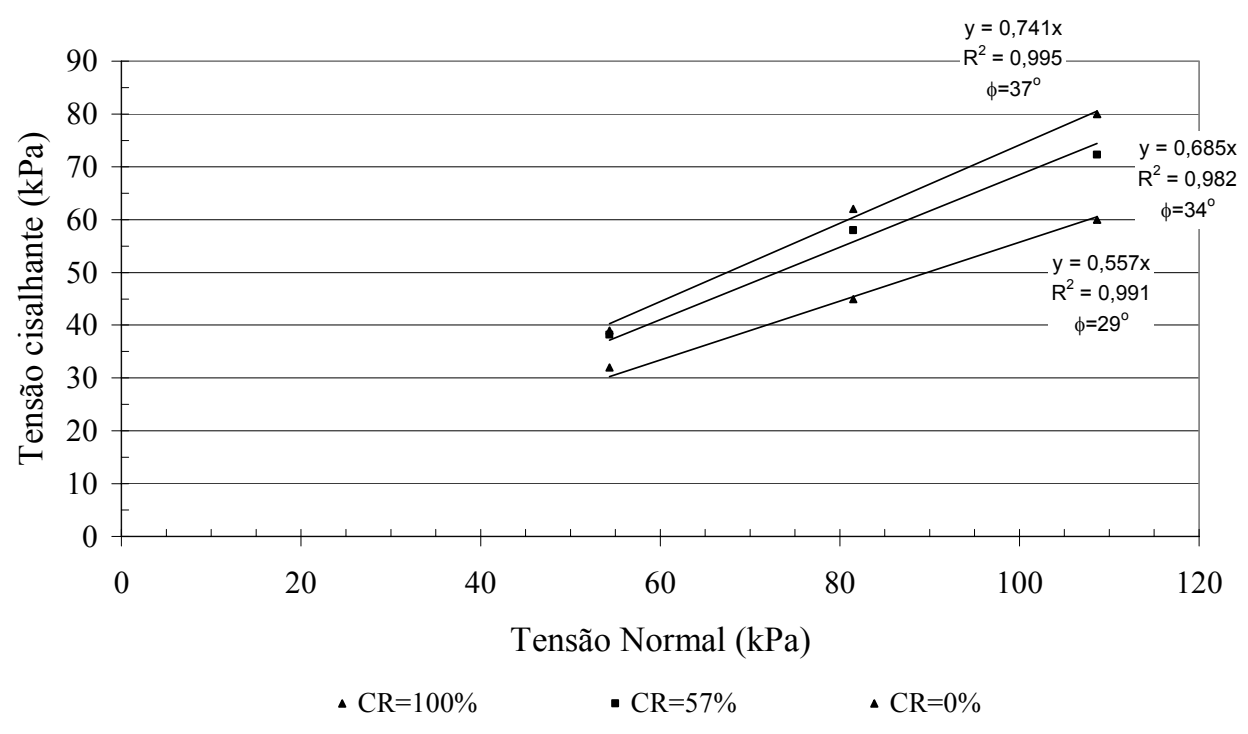

Figura 4.1.1.9. Envoltória de resistência- Ring shear.

Os valores de ângulos de atrito internos obtidos para o material granular são resumidos na Tabela 4.1.2.

Tabela 4.1.2. Sumário- Valores dos ângulos de atrito internos.

\begin{tabular}{lcc}
\hline Compacidade & C. Direto & Ring Shear \\
\hline Mínima $\left(\mathrm{CR}=0 \% ; \gamma_{d}=14,62 \mathrm{kN} / \mathrm{m}^{3} ; e=0,83\right)$ & $32 \circ$ & $29 \circ$ \\
Média $\left(\mathrm{CR}=57 \% ; \gamma_{d}=16,04 \mathrm{kN} / \mathrm{m}^{3} ; \mathrm{e}=0,68\right)$ & $44 \circ$ & $34 \circ$ \\
Compacta $\left(\mathrm{CR}=100 \% ; \gamma_{d}=17,45 \mathrm{kN} / \mathrm{m}^{3} ; e=0,53\right)$ & $46 \circ$ & 370 \\
\hline
\end{tabular}

Observa-se que os valores dos ângulos de atrito interno obtidos por cisalhamento direto e ring shear são diferentes, encontrando-se menores ângulos nos ensaios de ring shear. Isto pode ser explicado por dois fatores. Primeiro, no ensaio de cisalhamento direto a ruptura do material ocorre num plano pré-definido; enquanto no ring shear, a ruptura pode ocorrer no plano mais fraco do material. Segundo, alguns autores defendem que no cisalhamento direto os ângulos são maiores devido à rigidez lateral e frontal da caixa; enquanto no ring shear, a condição de rigidez da caixa é dada somente pelas laterais do anel. 


\subsubsection{Solo argiloso}

O solo argiloso empregado apresenta sua distribuição granulométrica conforme Figura 4.1.2.1. Na Tabela 4.1.2.1 são apresentadas as características gerais da argila siltosa (amostra 2).

A Figura A.1, que se encontra no Anexo A, apresenta as curvas de compactação do ensaio de Proctor, correspondentes a duas amostras da área do aterro sanitário de Piracicaba- SP.

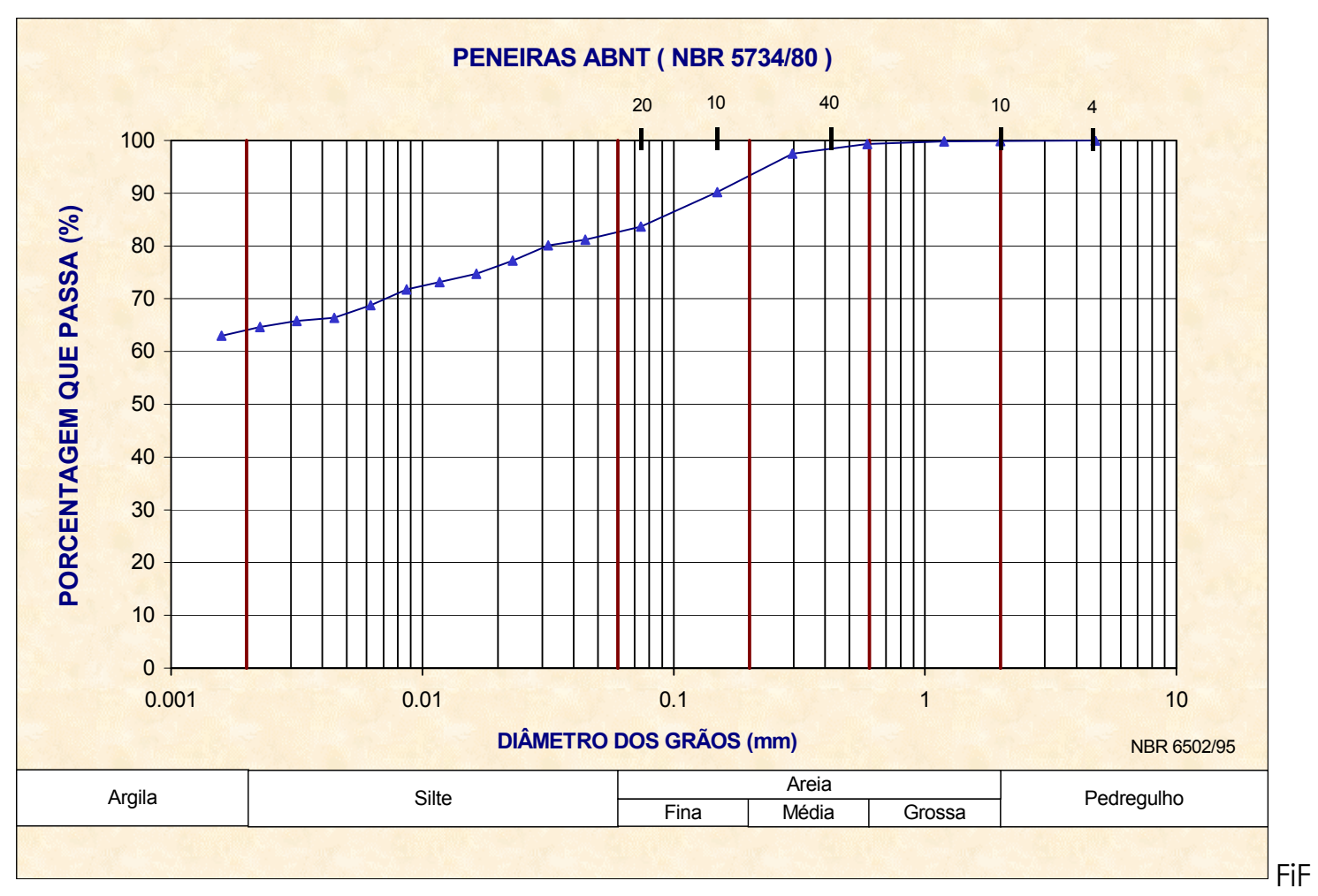

Figura 4.1.2.1. Curva granulométrica do solo argiloso. 
Tabela 4.1.2.1. Características do solo argiloso utilizado nos ensaios.

\begin{tabular}{lc}
\hline Propriedades & \\
\hline Classificação do solo & Argila siltosa pouco arenosa- solo \\
laterítico & $30,7 \mathrm{kN} / \mathrm{m}^{3}$ \\
Peso específico dos sólidos, $\gamma_{\mathrm{s}}$ & \\
Proctor normal & $15,9 \mathrm{kN} / \mathrm{m}^{3}$ \\
Peso específico seco máximo, $\gamma$ d ótimo & $26,7 \%$ \\
Umidade ótima Wótima & $55 \%$ \\
Limite de liquidez & $32 \%$ \\
Limite de plasticidade & $22 \%$ \\
Índice de plasticidade & \\
Coeficiente de condutividade hidráulica & \\
(cm/s) & \\
W ótima & \\
SP 01 & $5,3 \times 10^{-7}$ \\
SP 05 & $2,4 \times 10^{-7}$ \\
SP 01 & \\
SP 05 & $2,0 \times 10^{-7}$ \\
W ótima + $2 \%$ & $2,3 \times 10^{-7}$ \\
\hline
\end{tabular}

Nas Figuras 4.1.2.2 e 4.1.2.3 são apresentadas as curvas de tensão cisalhante e variação de volume versus deslocamento e a envoltória de resistência deste material, obtidos por ensaios de ring shear. Para determinação da resistência, o solo foi moldado na umidade ótima $(26,7 \%)$ e GC igual a 98\%. Os ensaios foram realizados com adensamento da amostra, seguido de inundação do corpo de prova durante um período de aproximadamente 14 horas. A velocidade de cisalhamento aplicada foi $1,653 \mathrm{~mm} / \mathrm{min}$, tentando simular um comportamento não drenado. 

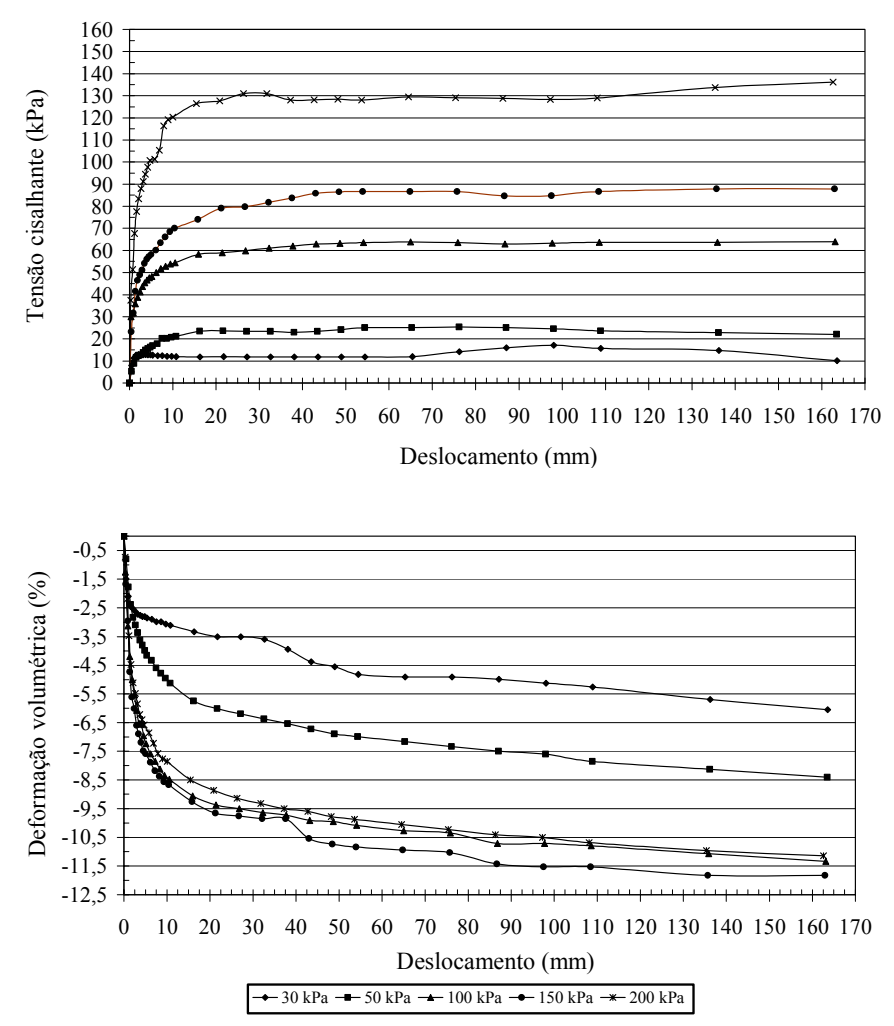

Figura 4.1.2.2. Resultados dos ensaios de ring shear em argila na umidade ótima e peso específico seco de 15,6 kN/m³ (GC=98\%). Ensaio inundado.

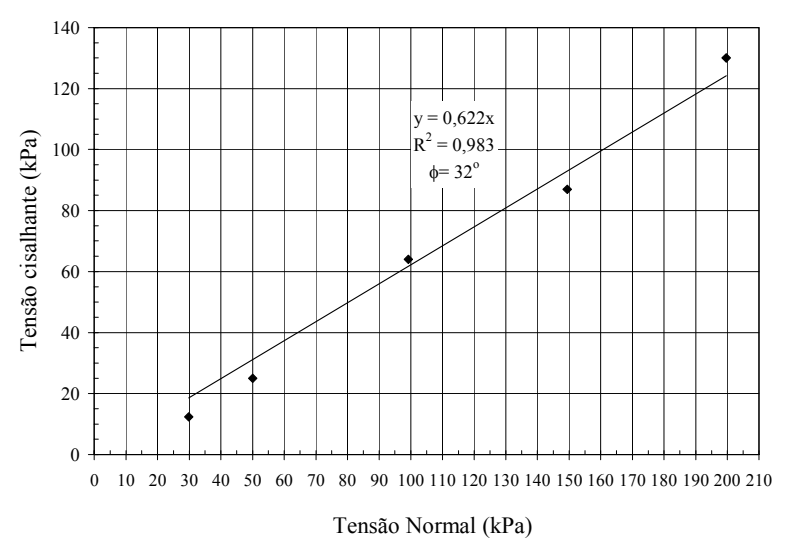

Figura 4.1.2.3. Envoltória de resistência- pico- Ring shear. Ensaio inundado.

Nas Figuras 4.1.2.4 e 4.1.2.5 são apresentadas as curvas de tensão cisalhante versus deslocamento e a envoltória de resistência da argila, obtidas através do ensaio de cisalhamento direto, com velocidade de $0,5 \mathrm{~mm} / \mathrm{min}$ e amostra inundada. 

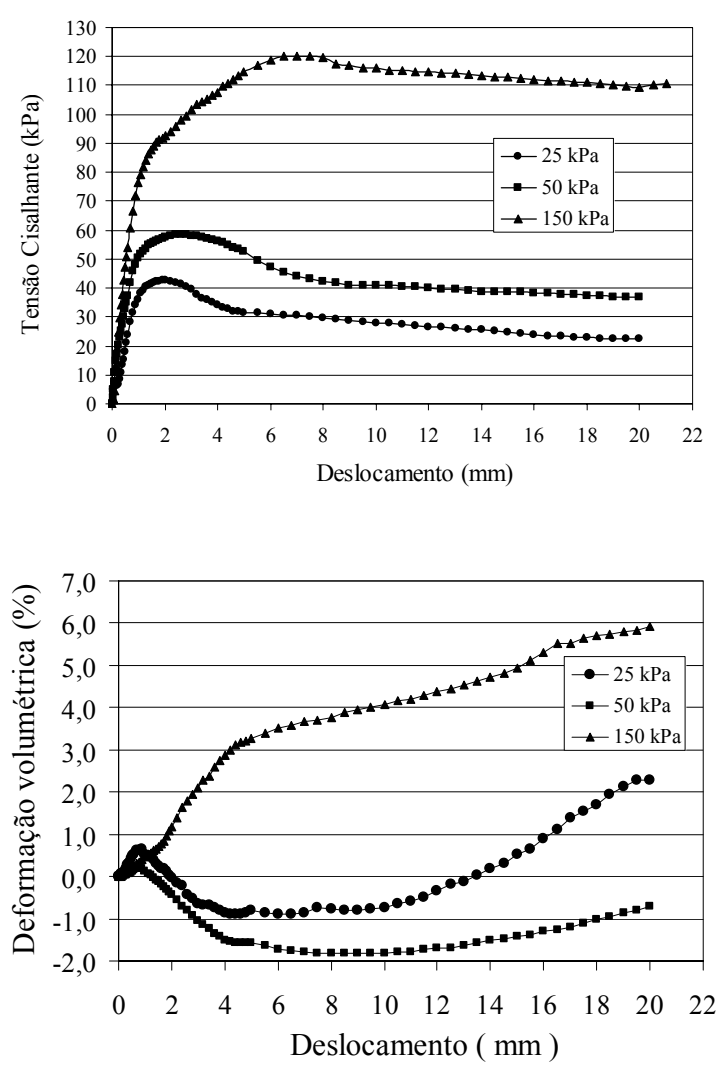

Figura 4.1.2.4. Resultados dos ensaios de cisalhamento direto em argila na umidade ótima e peso específico seco de $15,6 \mathrm{kN} / \mathrm{m}^{3}$ (GC=98\%). Ensaio inundado.

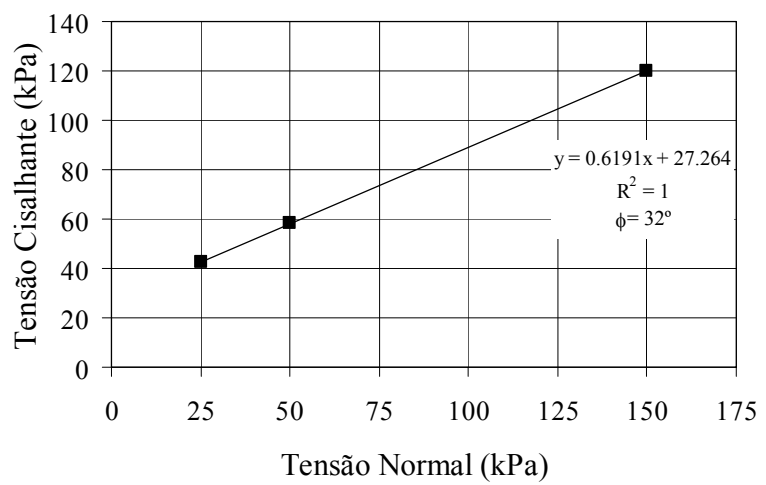

Figura 4.1.2.5. Envoltória de resistência- pico- Cisalhamento Direto. Ensaio inundado.

Também foram realizados ensaios de resistência na argila nas mesmas condições de moldagem, porém sem inundação do corpo de prova. Nas Figuras 4.1.2.6 e 4.1.2.7 são apresentados os resultados dos ensaios de ring shear. 

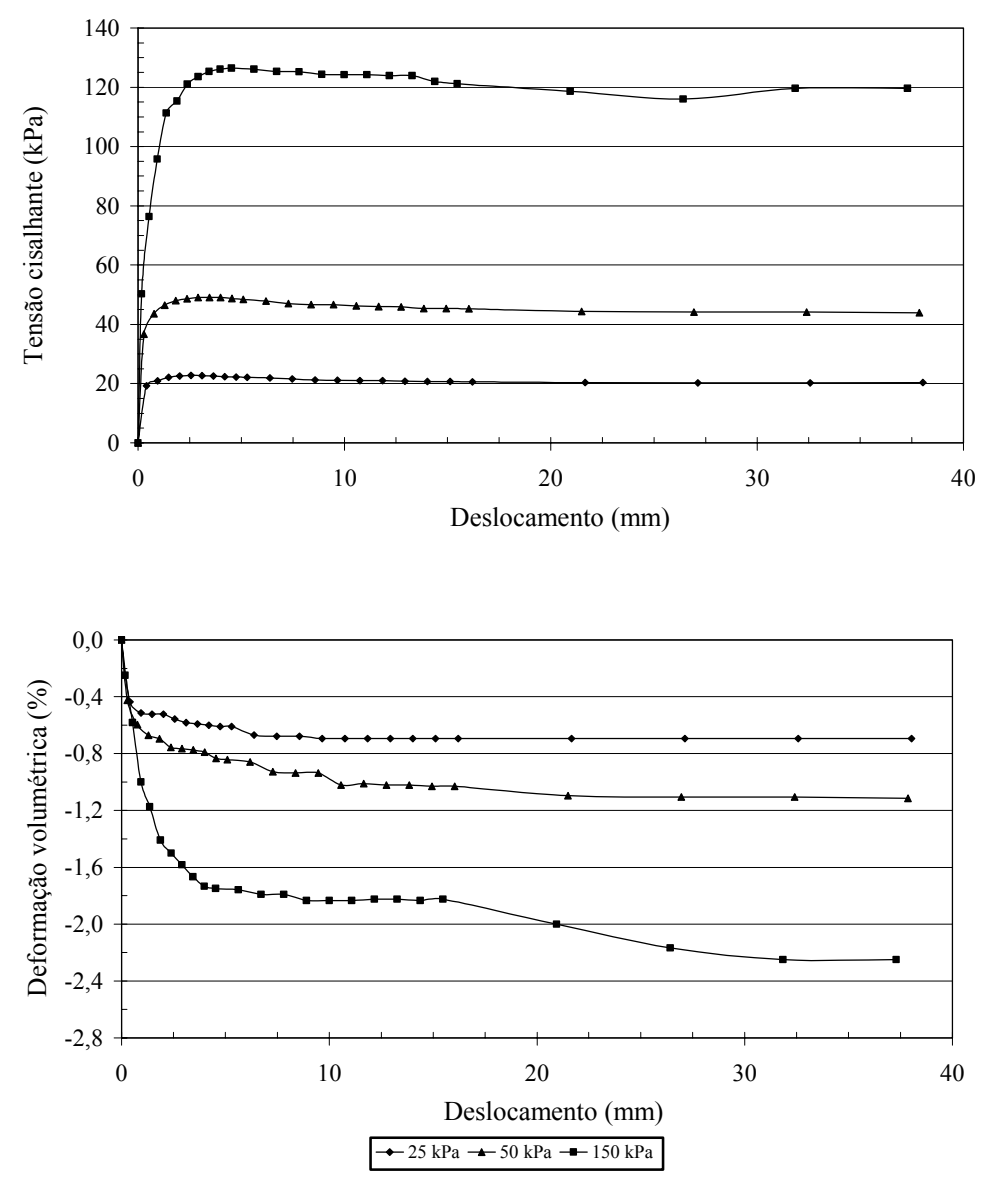

Figura 4.1.2.6. Resultados dos ensaios de ring shear em argila na umidade ótima e peso específico seco de 15,6 kN/m³ (GC=98\%). Ensaio não inundado.

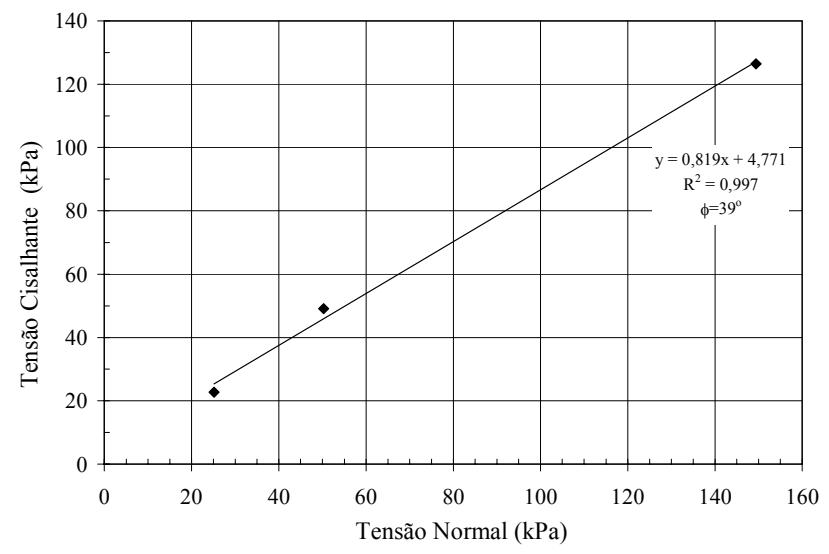

Figura 4.1.2.7. Envoltória de resistência- pico- Ring shear. Ensaio não inundado.

Nas Figuras 4.1.2.8 e 4.1.2.9 são apresentados os resultados de resistência, obtidos por ensaios de cisalhamento direto. 

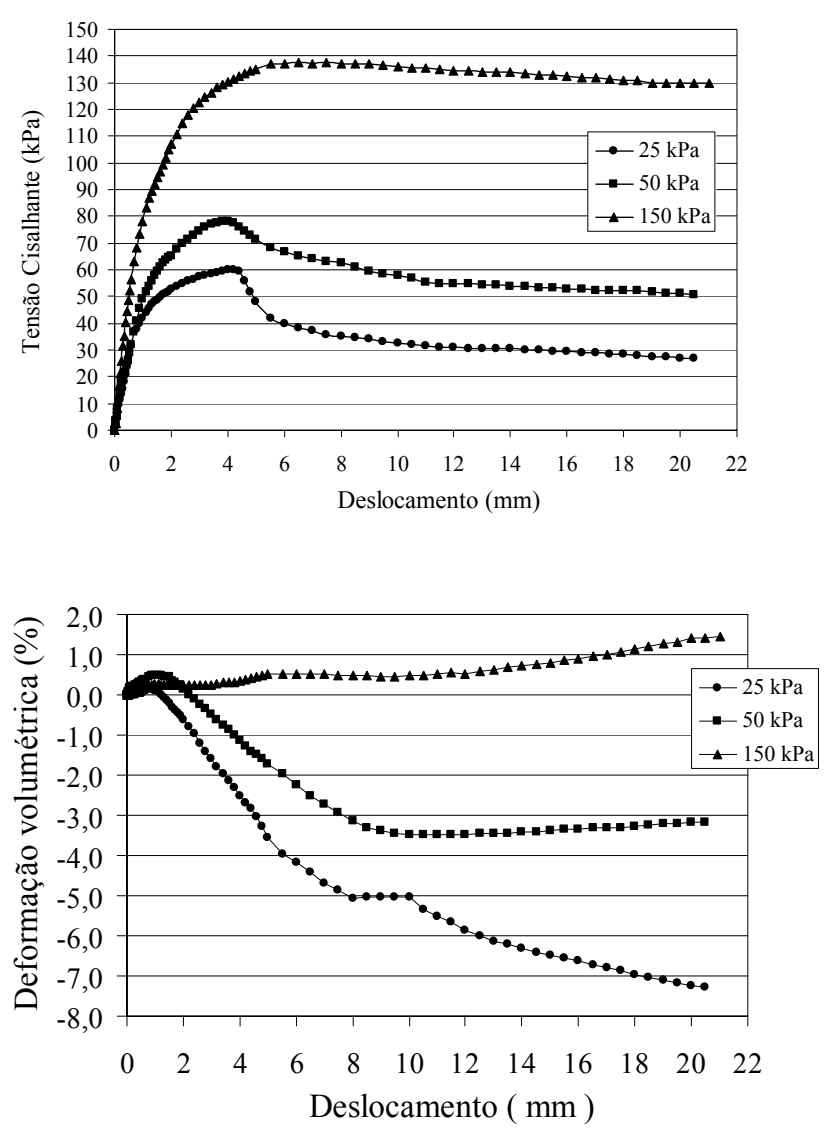

Figura 4.1.2.8. Resultados dos ensaios de cisalhamento direto em argila na umidade ótima e peso específico seco de $15,6 \mathrm{kN} / \mathrm{m}^{3}$ (GC=98\%). Ensaio não inundado.

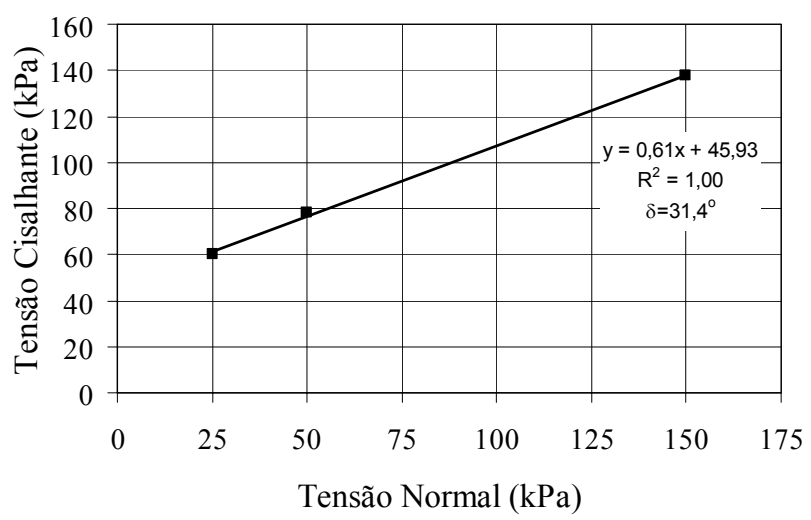

Figura 4.1.2.9. Envoltória de resistência- pico- Cisalhamento Direto. Ensaio não inundado. 
O sumário dos resultados obtidos são apresentados na Tabela 4.1.2.2.

Tabela 4.1.2.2. Parâmetros de resistência da argila.

\begin{tabular}{lcccc}
\hline \multirow{2}{*}{ Condição de Compactação } & \multicolumn{2}{c}{ Ring shear } & \multicolumn{2}{c}{ Cis. Direto } \\
\cline { 2 - 5 } & $c(\mathrm{kPa})$ & $\phi^{\prime}$ & $c(\mathrm{kPa})$ & $\phi^{\prime}$ \\
\hline W ótima=26,7\%, CG=98\% e & 0 & $32^{\circ}$ & 27 & $32^{\circ}$ \\
$\begin{array}{l}\text { inundado } \\
\text { W ótima=26,7\%, CG=98\%, não }\end{array}$ & 4,8 & $39^{\circ}$ & 45,9 & $31,4^{\circ}$ \\
inundado & & & & \\
\hline
\end{tabular}

Verifica-se que, em ambos os tipos de ensaios, os valores de ângulo de atrito interno da argila são altos, o que pode ser explicado pelo tipo do sololaterítico e arenoso. Observa-se ainda que os valores de ângulos de atrito são aproximadamente iguais em ambos os ensaios realizados sob condição inundada. Por sua vez, na condição não inundada observa-se uma diferença nos ângulos de atrito interno. A maior discrepância encontrada nos resultados foi o parâmetro coesão.

\subsubsection{Geomembranas}

As curvas obtidas a partir dos ensaios de tração (métodos ASTM D 63896 e D 882-95a) nas geomembranas são apresentadas no Apêndice A, e os resultados são sumarizados na Tabela 4.1.3.1. 
Tabela 4.1.3.1. Resultados dos ensaios de tração.

\begin{tabular}{|c|c|c|c|c|}
\hline GM & Sentido & $\begin{array}{l}\text { F máxima } \\
(\mathrm{N})\end{array}$ & $\begin{array}{c}\text { Def. Específica } \\
\text { Max. } \\
(\%)\end{array}$ & $\begin{array}{c}\text { Tensão } \\
\text { Máxima } \\
\text { (MPa) }\end{array}$ \\
\hline PVC & Long. & 96,19 & 527,2 & 16,03 \\
\hline$(1 \mathrm{~mm})$ & Transv. & 85,90 & 535,1 & 14,32 \\
\hline PEAD & Long. & 295,4 & 1307 & 32,82 \\
\hline$(1,0 \mathrm{~mm})$ & Transv. & 287,7 & 1456 & 31,97 \\
\hline PELMD & Long. & 262,1 & 620,7 & 20,64 \\
\hline$(0,5 \mathrm{~mm})$ & Transv. & 244,2 & 187,2 & 19,23 \\
\hline PEAD A & Long. & 229,7 & 573,3 & 15,31 \\
\hline$(2,0 \mathrm{~mm})$ & Transv. & 223,4 & 817,2 & 18,62 \\
\hline PEAD AR & Long. & 263,9 & 791,8 & 17,59 \\
\hline$(2,5 \mathrm{~mm})$ & Transv. & 276,9 & 782 & 18,46 \\
\hline
\end{tabular}

\subsection{ENSAIOS DE RESISTÊNCIA DE INTERFACE ENTRE GEOMEMBRANAS E AREIA}

\subsubsection{Ensaios de Ring shear}

Com a finalidade de averiguar a confiabilidade dos resultados obtidos, os ensaios de resistência de interface entre geomembranas e areias foram reproduzidos de duas a três vezes para cada estado de compacidade. Observou-se que as variações dos ângulos de interface obtidos foram pequenas, sendo apresentadas abaixo as curvas representativas. As demais curvas são apresentadas no Apêndice B.

As curvas apresentadas nas Figuras 4.2.1.1, 4.2.1.2 e 4.2.1.3 mostram as curvas tensão cisalhante e deformação volumétrica versus deslocamento para a interface areia/geomembrana de PVC. Tais curvas estão relacionadas à compacidade mínima ( $\left.C R=0 \% ; \gamma_{d}=14,6 \mathrm{kN} / \mathrm{m}^{3} ; \quad e=0,83\right)$, média $(C R=57 \%$; $\left.\gamma_{d}=16,0 \mathrm{kN} / \mathrm{m}^{3} ; \quad e=0,68\right)$ e máxima (CR=100\%; $\left.\gamma_{d}=17,4 \mathrm{kN} / \mathrm{m}^{3} ; \quad e=0,53\right)$, respectivamente. 

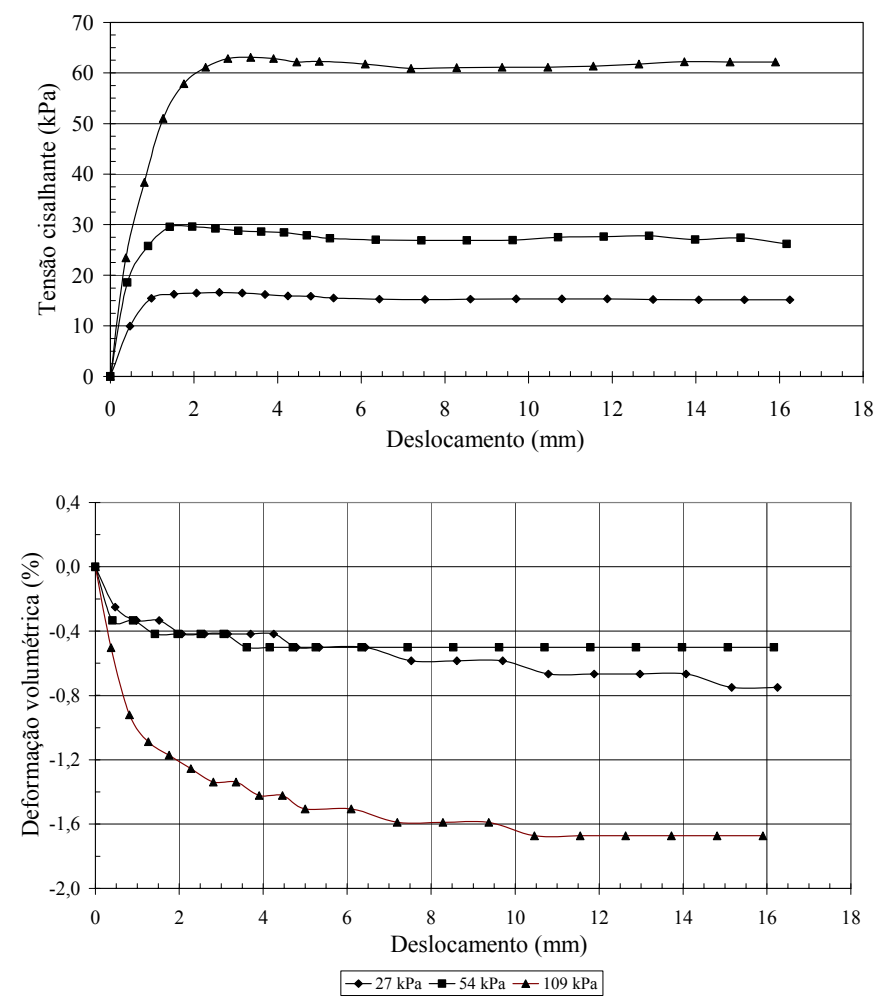

Figura 4.2.1.1. Resultados dos ensaios de interface areia/ $P V C-C R=0 \%-1^{a}$ série.
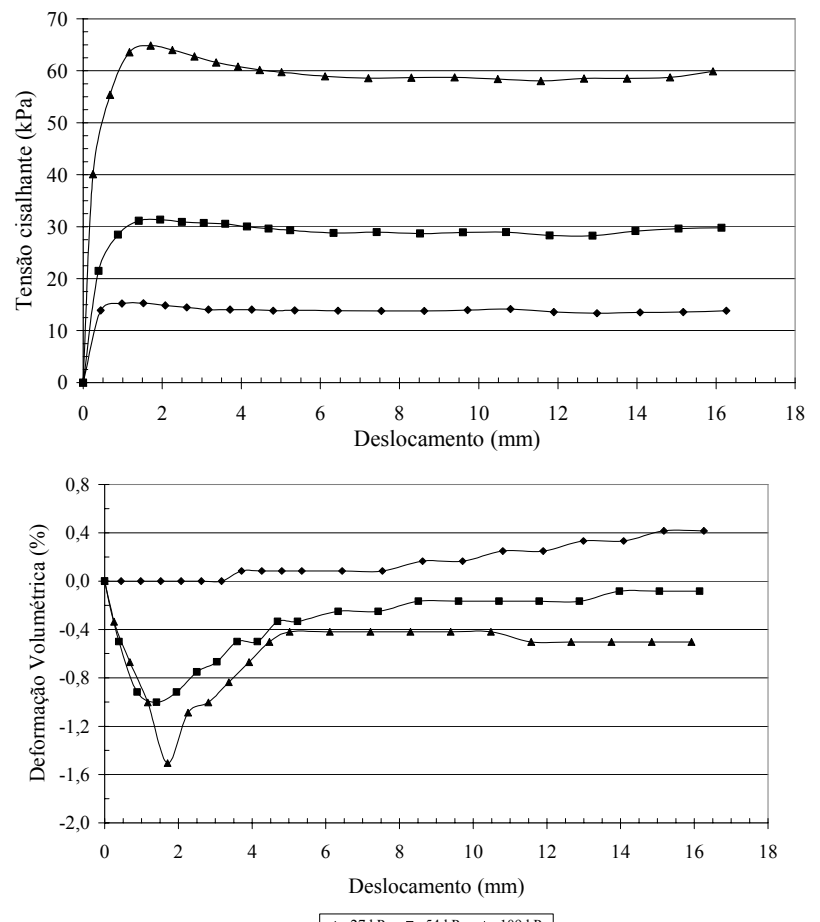

$\rightarrow-27 \mathrm{kPa}-54 \mathrm{kPa} \leftarrow 109 \mathrm{kPa}$

Figura 4.2.1.2. Resultados dos ensaios de interface areia/ $P V C-C R=57 \%-1^{a}$ série. 

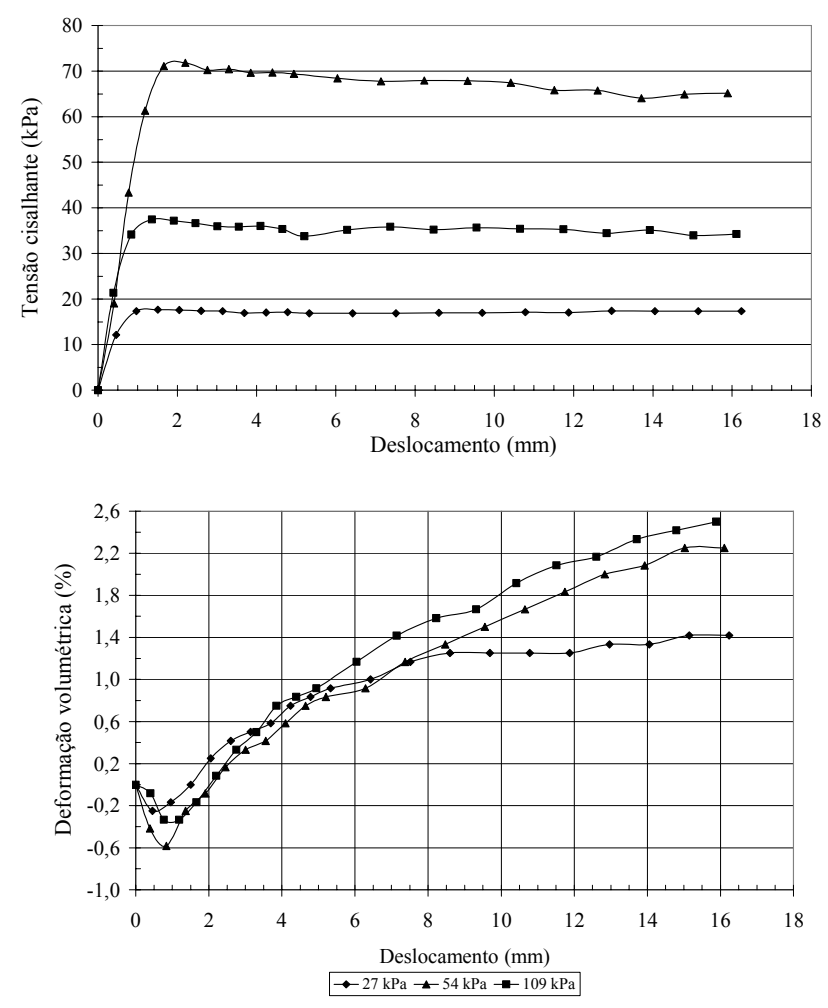

Figura 4.2.1.3. Resultados dos ensaios de interface areia/ PVC-CR $=100 \%-1^{a}$ série.

De acordo com os resultados apresentados, verificou-se que a tensão cisalhante de pico em interfaces PVC/areia foi mobilizada para deslocamentos entre 1,5 a 2,5mm. Verificou-se também, que após atingir a resistência de pico, houve um decréscimo de resistência até atingir a condição residual, mobilizada com deslocamentos de aproximadamente $5 \mathrm{~mm}$.

Nota-se, ainda, que nas areias fofas ocorreu compressão do material durante todo a fase de cisalhamento. Ao contrário, nas areias com compacidade média e compactas, verificou-se um estágio de compressão seguido de expansão volumétrica. Verificou-se que a tensão cisalhante de pico é mobilizada no ponto de maior inclinação da curva durante a fase de expansão, a qual corresponde ao ângulo de dilatância. A partir deste ponto, ocorre perda de resistência pós-pico. Desta forma, averiguou-se que o comportamento de resistência de interface com areia compacta e medianamente compacta pode estar associado ao efeito de dilatância da areia. 
Para o estado mínimo de compacidade, a perda de resistência póspico foi de aproximadamente 5\%, 9\% e 5\% para os carregamentos de 27kPa, $54 \mathrm{kPa}$ e $109 \mathrm{kPa}$. No estado médio de compacidade, esta relação foi equivalente a $4 \%, 9 \%$ e $11 \%$, enquanto no estado compacto, $2 \%, 6 \%$ e $10 \%$. Observa-se que, para baixos carregamentos (27kPa), a tensão cisalhante de pico é aproximadamente igual à tensão residual. Contudo para carregamentos mais elevados (54kPa e 109kPa), verifica-se maior perda de tensão cisalhante pós-pico. Este comportamento foi verificado em todos os estados de compacidade da areia.

As curvas apresentadas nas Figuras 4.2.1.4, 4.2.1.5 e 4.2.1.6 mostram o comportamento de resistência para geomembranas de PEAD lisa.
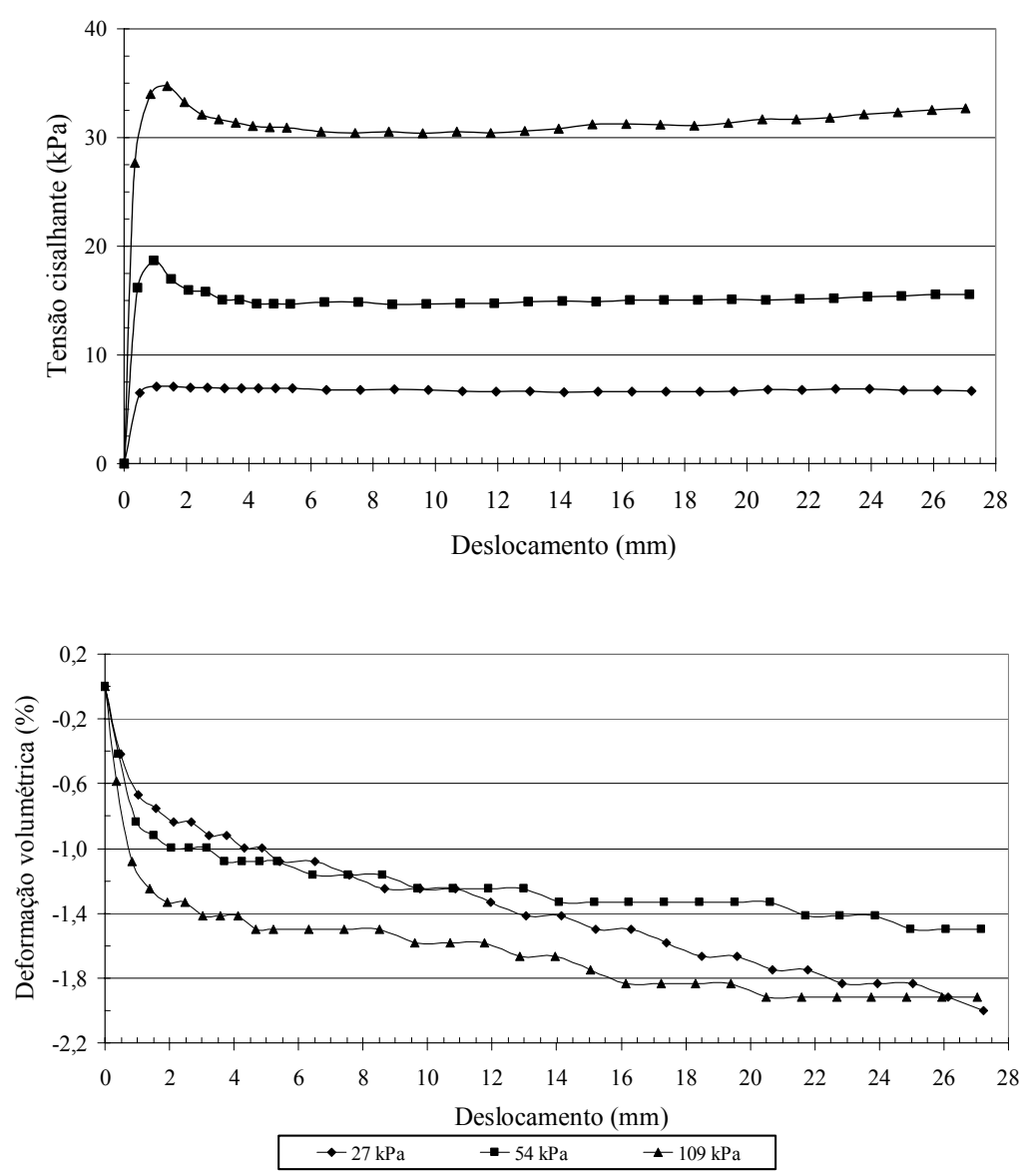

Figura 4.2.1.4. Resultados dos ensaios de interface areia/ PEAD-CR=0\%- $1^{a}$ série. 

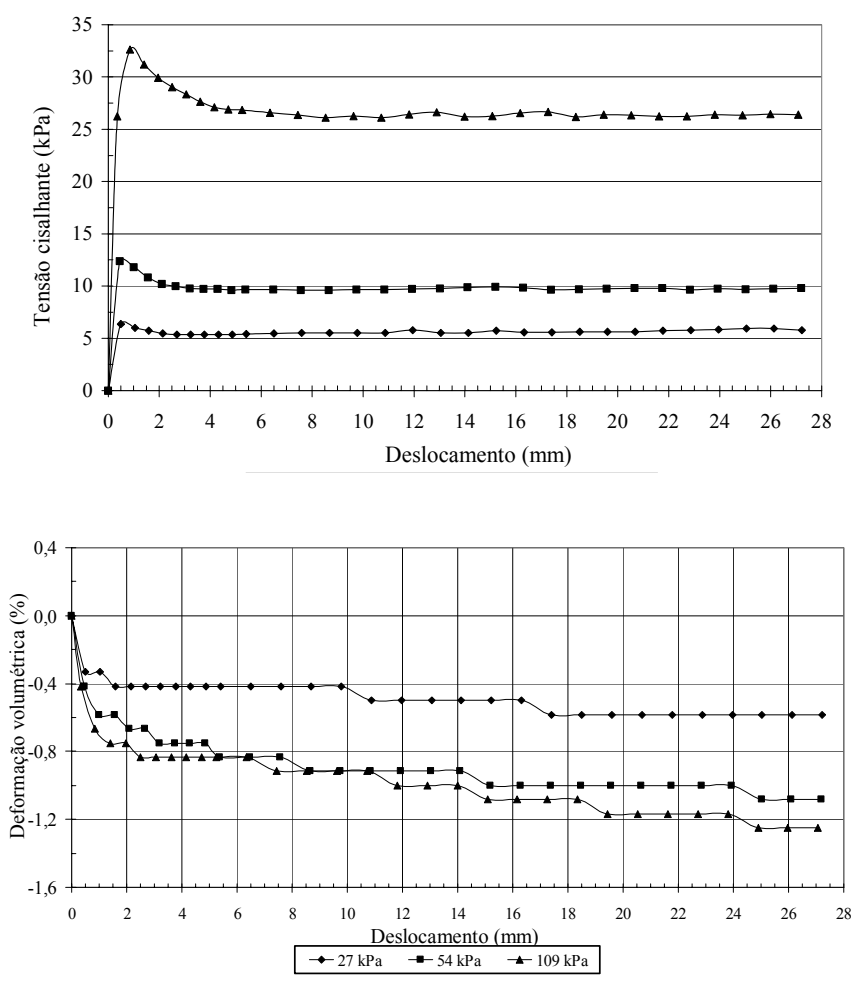

Figura 4.2.1.5. Resultados dos ensaios de interface areia/ PEAD-CR $=57 \%-1^{a}$ série.
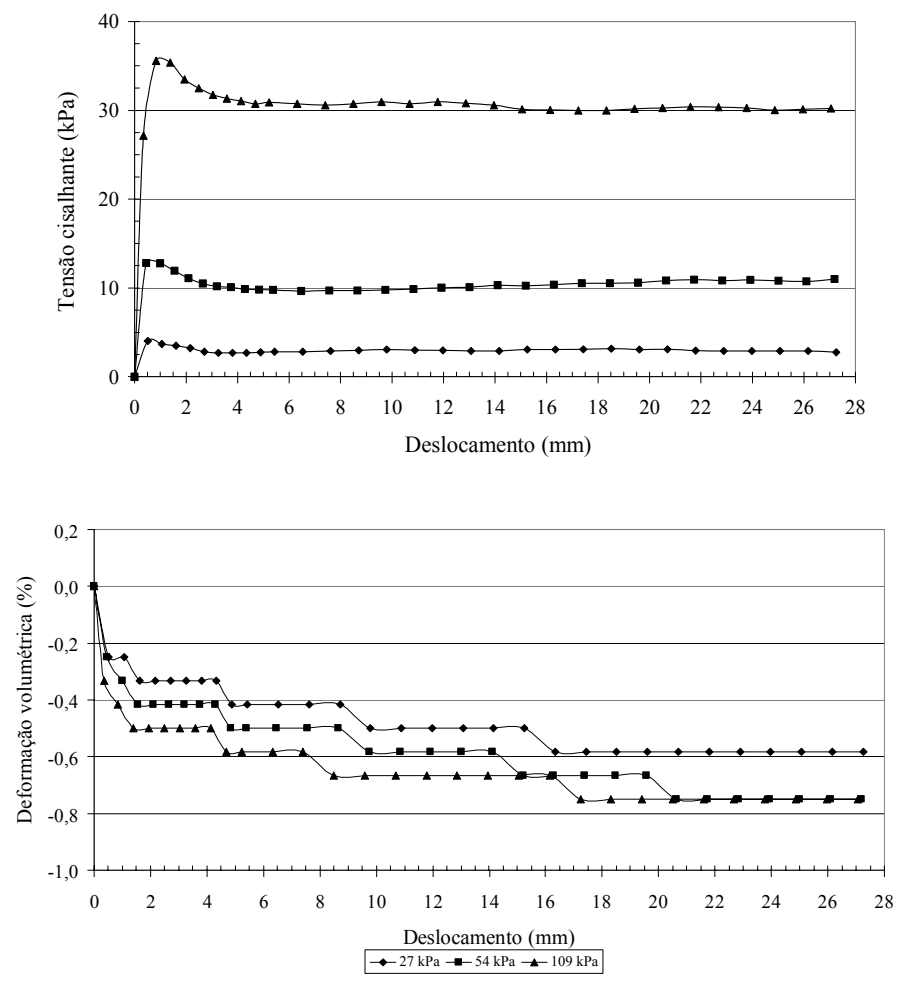

Figura 4.2.1.6. Resultados dos ensaios de interface areia/ PEAD-CR=100\%- $1^{a}$ série. 
Constatou-se que nas geomembranas de PEAD lisa, a tensão cisalhante de pico foi mobilizada para deslocamentos em torno de 0,5 a 1,5mm. Também se observou que houve decréscimo de tensão cisalhante póspico para todos os níveis de tensões, atingindo-se a condição residual com deslocamentos por volta de 5 a $6 \mathrm{~mm}$.

Para o estado mínimo de compacidade, verificou-se que a perda de tensão cisalhante pós-pico é de $7 \%, 22 \%$ e $13 \%$ para os carregamentos de $27 \mathrm{kPa}, 54 \mathrm{kPa}$ e $109 \mathrm{kPa}$, respectivamente. Para $\mathrm{O}$ estado médio de compacidade, corresponde a $17 \%, 22 \%$ e $21 \%$, e no estado máximo, $24 \%, 19 \%$ e $12 \%$. Comparando estas relações com as obtidas nas geomembranas de PVC, verificou-se que nas geomembranas de PEAD, a perda de tensão cisalhante pós-pico é mais acentuada.

Ao contrário do observado nas geomembranas de PVC, verificou-se que o comportamento de deformação volumétrica é diferente nas geomembranas de PEAD lisa. Nestas, nota-se que houve apenas compressão do material para todos níveis de compacidade da areia, inclusive para a areia no estado compacto. Uma possível explicação é que nas geomembranas lisas de PEAD por serem rígidas não ocorre o rolamento dos grãos de areia, mas sim o deslizamento, de modo que não ocorra expansão volumétrica do material. Diferentemente das geomembranas de PVC que, por serem flexíveis, permitem o rolamento dos grãos e conseqüentemente o efeito da dilatância.

As Figuras 4.2.1.7, 4.2.1.8 e 4.2.1.9 mostram o comportamento de resistência em interfaces com geomembrana de PELMD. 

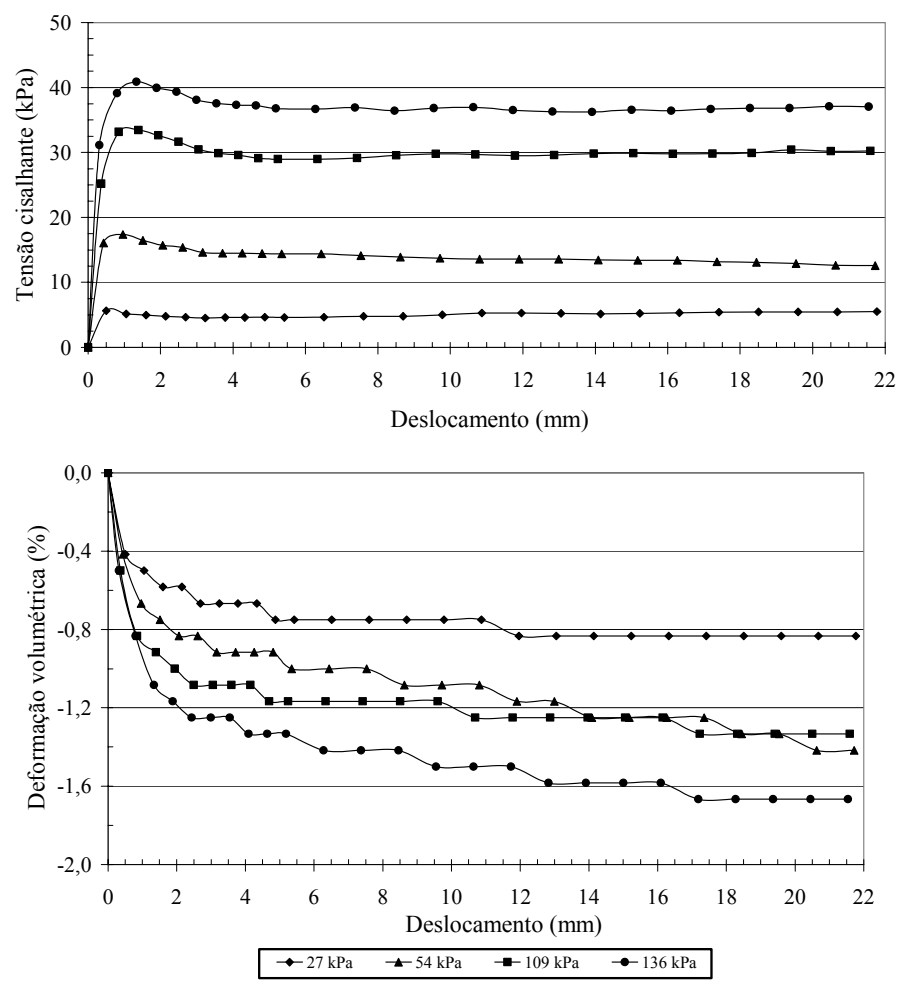

Figura 4.2.1.7. Resultados dos ensaios de interface areia/PE linear- $C R=0-1^{a}$ série.
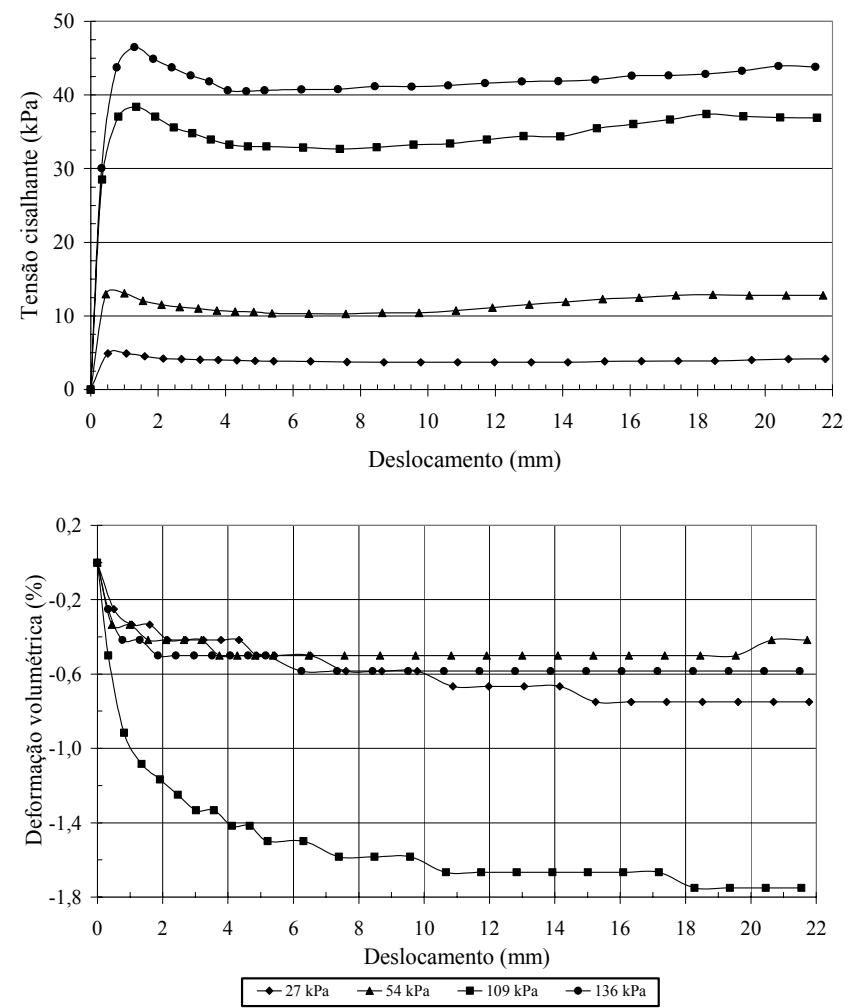

Figura 4.2.1.8. Resultados dos ensaios de interface areia/PE linear- $C R=57 \%-1^{a}$ série. 

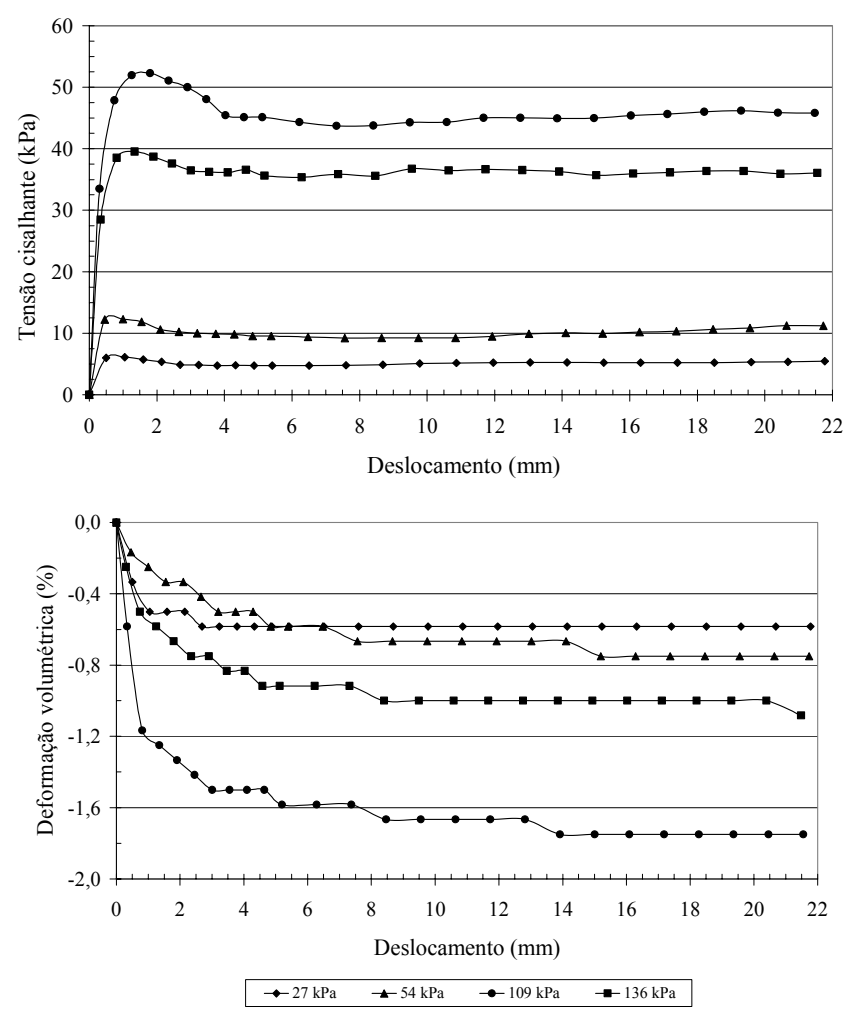

Figura 4.2.1.9. Resultados dos ensaios de interface areia/PE linear- $C R=100 \%-1^{a}$ série.

Verifica-se que o comportamento de tensão cisalhante com geomembranas de PELMD é semelhante ao de PEAD lisa. A tensão cisalhante de pico também foi mobilizada para deslocamentos em torno de 0,5 a 1,5mm, atingindo-se a condição residual por volta de 5 a $6 \mathrm{~mm}$. Foram verificadas perdas de tensão cisalhante no estado mínimo de compacidade de $12 \%, 18 \%$, $17 \%$ e $17 \%$ para os carregamentos de $25 \mathrm{kPa}, 54 \mathrm{kPa}, 109 \mathrm{kPa}$ e $136 \mathrm{kPa}$, respectivamente. No estado médio de compacidade, foram obtidos $24 \%, 21 \%$, $15 \%$ e $10 \%$, e no estado compacto, $18 \%, 20 \%, 11 \%$ e $13 \%$.

Nas Figuras 4.2.1.10, 4.2.1.11 e 4.2.1.12 são apresentadas as curvas de tensão cisalhante e de deformação volumétrica versus deslocamento para geomembranas texturizadas do tipo PEAD-A. 

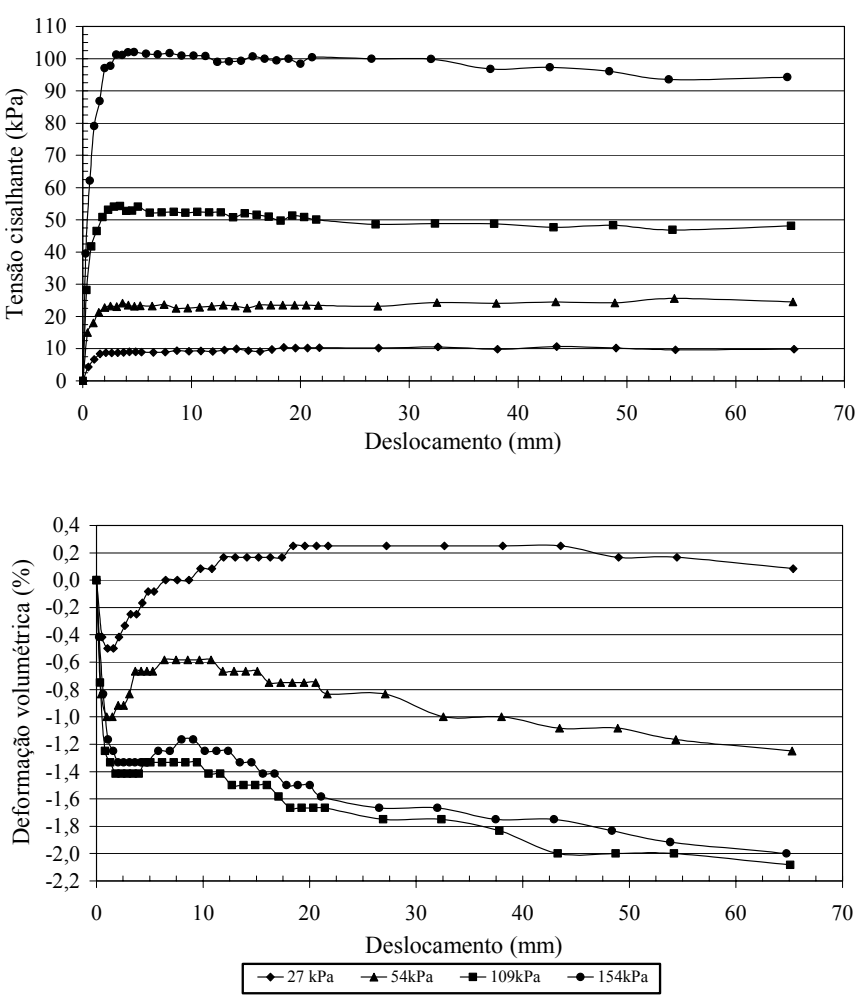

Figura 4.2.1.10. Resultados dos ensaios de interface areia/ PEAD A- CR=0\%- $1^{a}$ série.
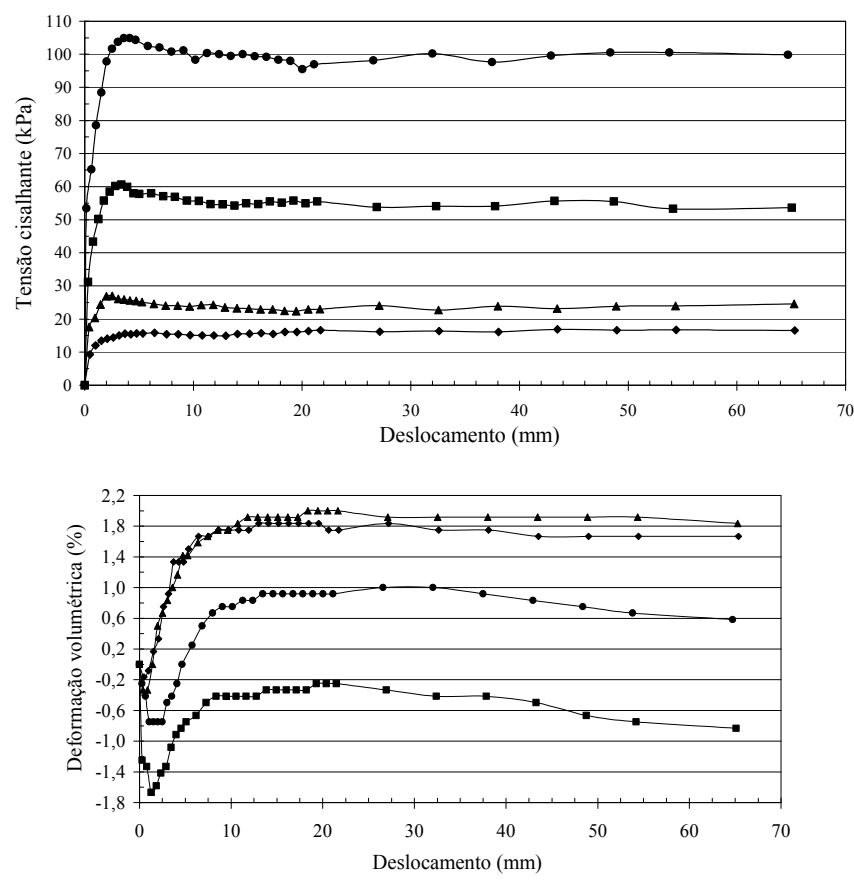

$\rightarrow 27 \mathrm{kPa} \quad \leftarrow 54 \mathrm{kPa} \quad-109 \mathrm{kPa} \quad \bullet-154 \mathrm{kPa}$

Figura 4.2.1.11. Resultados dos ensaios de interface areia/ PEAD A- $C R=57 \%-1^{a}$ série. 

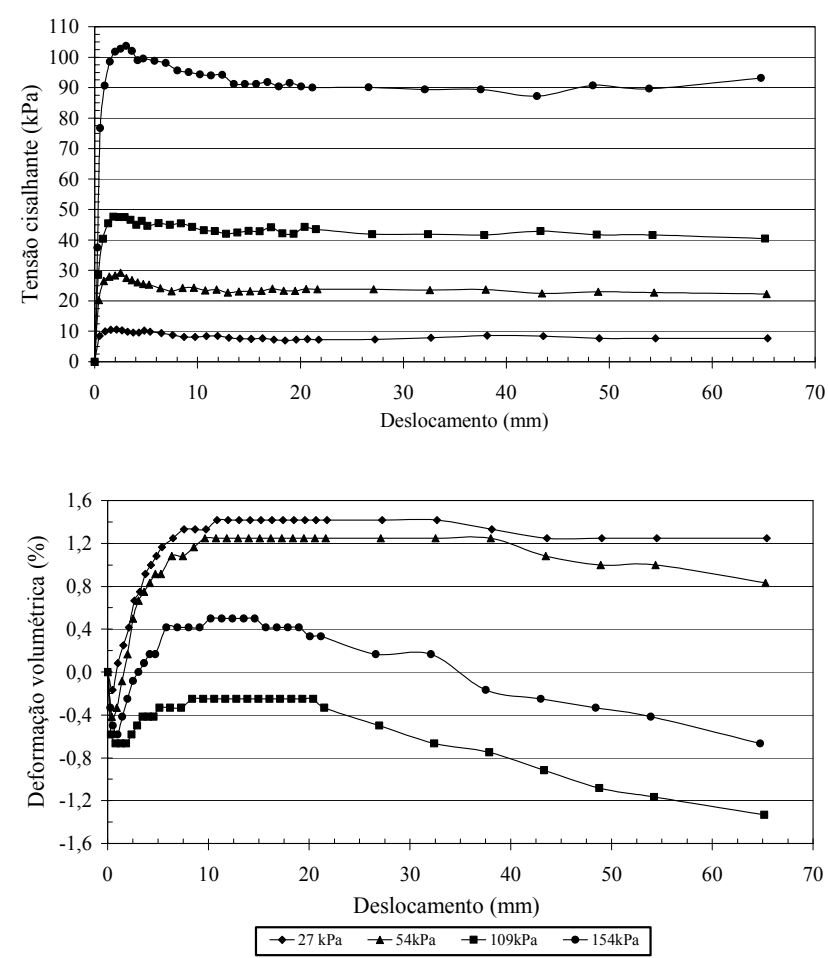

Figura 4.2.1.12. Resultados dos ensaios de interface areia/ PEAD A- CR=100\%$1^{\mathrm{a}}$ série.

Nas geomembranas de PEAD-A, averiguou-se que, devido à característica rugosa da geomembrana, a tensão cisalhante foi mobilizada para deslocamentos maiores do que os verificados para interfaces com PVC, PELMD e PEAD lisa, atingindo a condição de pico em torno de 2,0 a 4,0mm. Por sua vez, a tensão residual foi alcançada para deslocamentos maiores que $14 \mathrm{~mm}$.

Para o estado mínimo de compacidade, foram constatadas quedas de tensão cisalhante de $0 \%, 8 \%, 11 \%$ e 3\% nos carregamentos de $27 \mathrm{kPa}, 54 \mathrm{kPa}$, $109 \mathrm{kPa}$ e $204 \mathrm{kPa}$, respectivamente. Para o estado médio foram obtidos $4 \%, 8 \%$, $11 \%$ e $6 \%$, e para o estado compacto $29 \%, 17 \%, 10 \%$ e $13 \%$.

Analisando-se os gráficos de deformação volumétrica, percebeu-se que para o estado de compacidade mínima ocorre inicialmente uma compressão do material até atingir a resistência de pico. A partir deste ponto, verificou-se uma variação na deformação volumétrica com dilatação seguida de nova compressão. No estado de compacidade intermediária e máxima da areia, foi observado que a tensão cisalhante de pico ocorre no ponto de 
maior inclinação da curva de deformação volumétrica durante a fase de dilatância da areia. Após, verificou-se que há perda de resistência de interface até que atinja a condição residual.

As Figuras 4.2.1.13, 4.2.1.14 e 4.2.1.15 mostram o comportamento de tensão cisalhante versus deslocamento para as geomembranas texturizadas de PEAD-AR.
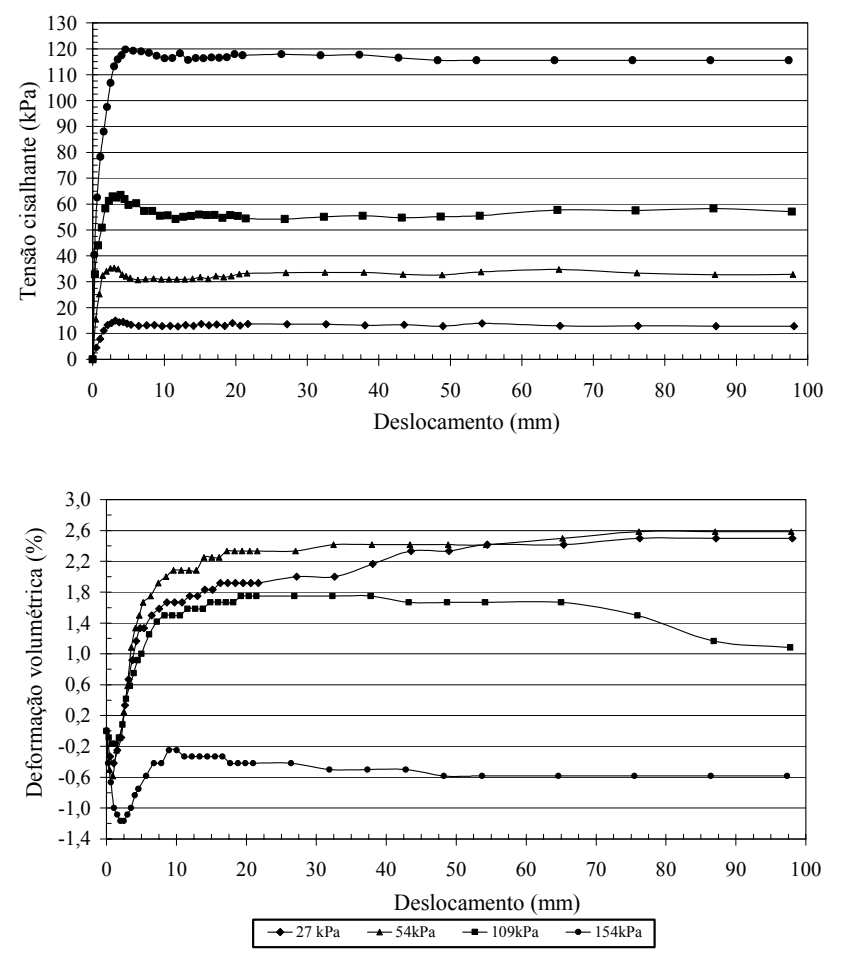

Figura 4.2.1.13. Resultados dos ensaios de interface areia/PEAD AR- $C R=0 \%-1^{a}$ série. 

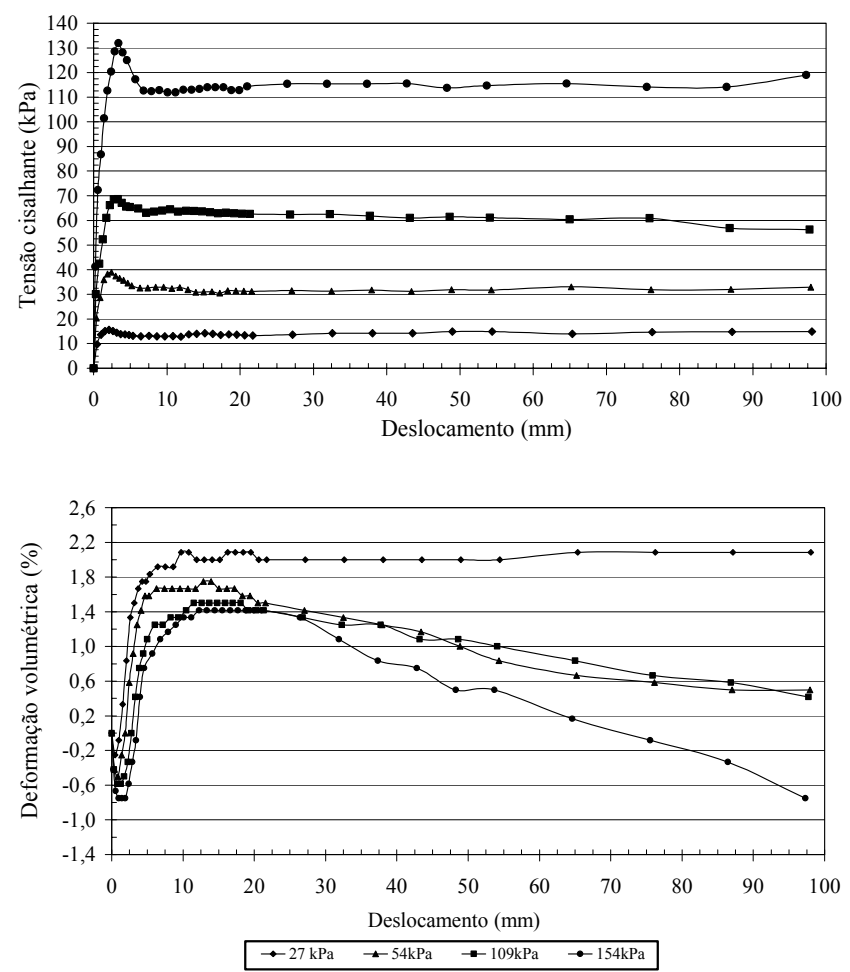

Figura 4.2.1.14. Resultados dos ensaios de interface areia/PEAD AR- $C R=57 \%$ -

$1^{\mathrm{a}}$ série.
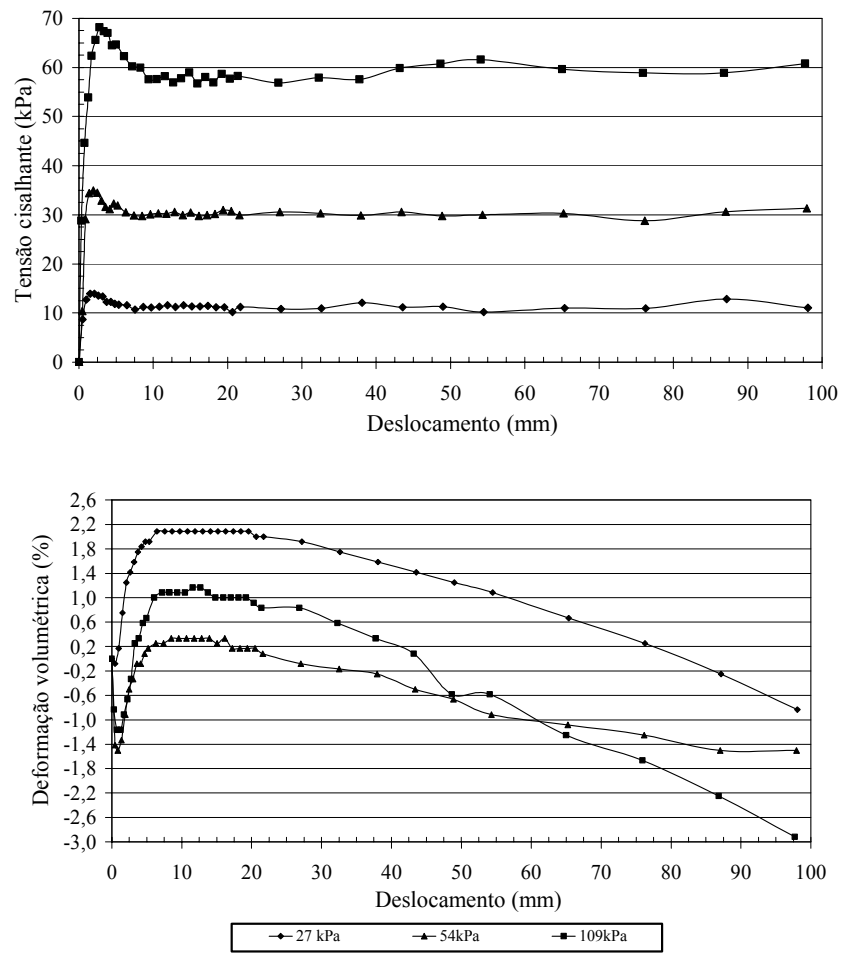

Figura 4.2.1.15. Resultados dos ensaios de interface areia/PEAD AR- $C R=100 \%$ -

$1^{a}$ série. 
As geomembranas de PEAD-AR apresentaram as curvas de tensão cisalhante versus deslocamento com comportamento semelhante às geomembranas de PEAD-A. Observa-se que a tensão cisalhante de pico foi mobilizada para deslocamentos em torno de 2,0 a 4,0mm, enquanto a tensão cisalhante residual para deslocamentos maiores que $14 \mathrm{~mm}$.

Para baixos carregamentos (27kPa), a redução de tensão cisalhante pós-pico foi por volta de $5 \%$ para todos os estados de compacidade. Entretanto, verificou-se que para carregamentos mais elevados, a queda de tensão cisalhante foi de aproximadamente $20 \%$. Tal mecanismo é atribuído ao aplainamento da superfície da geomembrana.

Verificou-se que em todos os estados de compacidade ocorre redução de volume, seguido de expansão do material. Foi observado que a resistência de pico ocorre na fase de dilatância, no ponto de máxima inclinação da curva, sendo verificado após um comportamento de perda de resistência. Sugere-se também que nesta interface há uma possível influência da dilatância no comportamento de resistência de interface.

\subsubsection{Envoltórias de Resistência}

As figuras abaixo apresentam as envoltórias de resistência médias das interfaces com geomembranas de PVC, PEAD lisa e PE linear, PEAD A e PEAD $A R$, referentes ao estado de compacidade mínimo, médio e máximo da areia. Estas envoltórias correspondem à média dos parâmetros de atrito obtidos nas repetições dos ensaios. A Tabela 4.2.2.1 faz uma síntese dos parâmetros de resistência encontrados. 


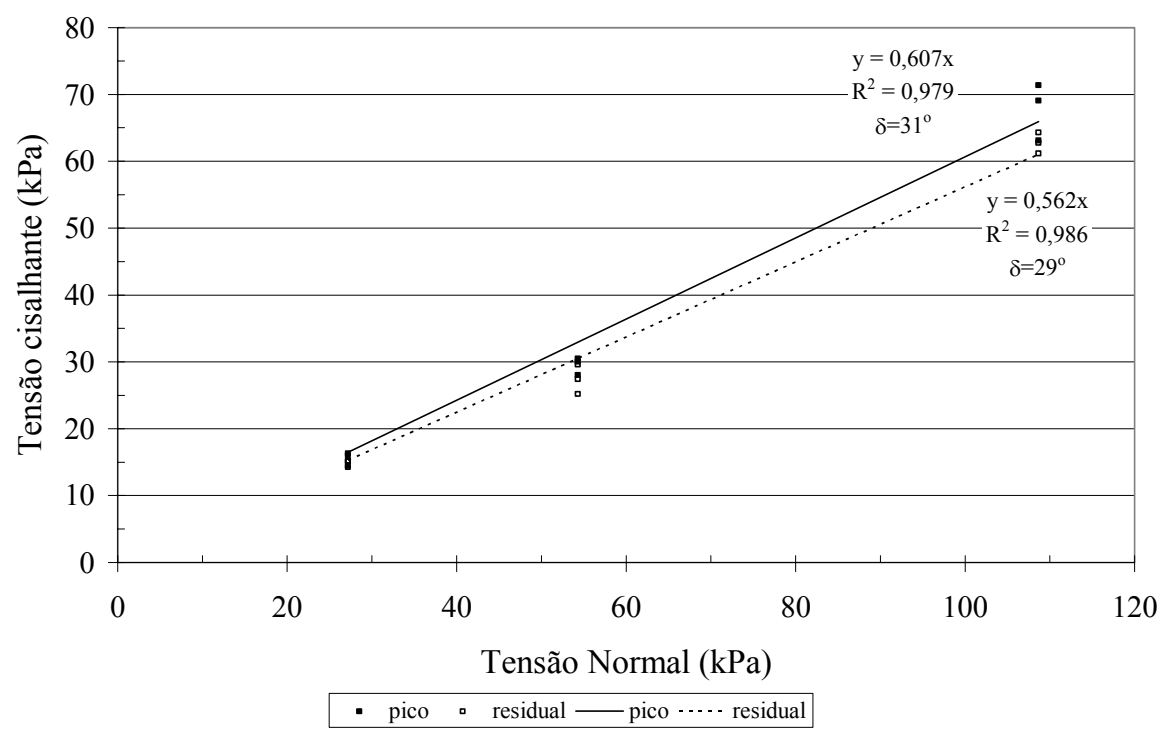

Figura 4.2.2.1. Envoltória de resistência- $\mathrm{PVC} /$ areia- $\mathrm{CR}=0 \%$.

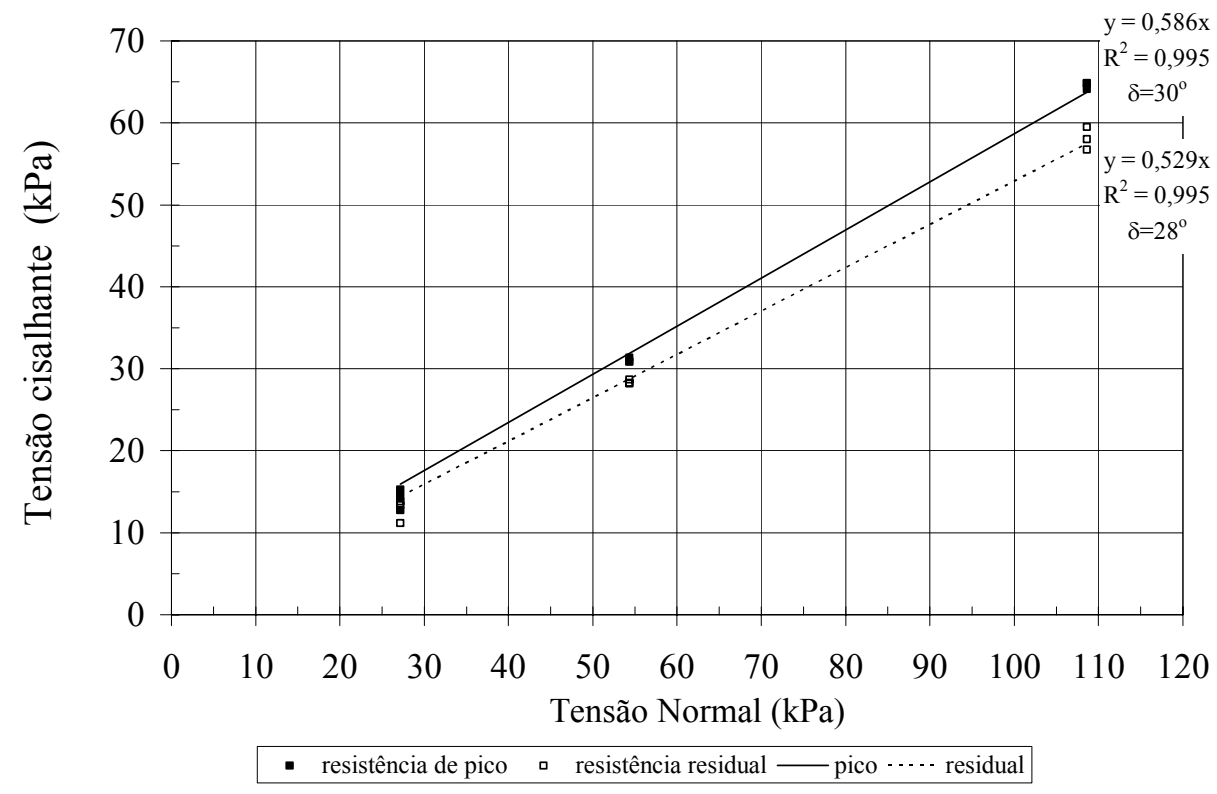

Figura 4.2.2.2. Envoltória de resistência- $P V C /$ areia- $C R=57 \%$. 


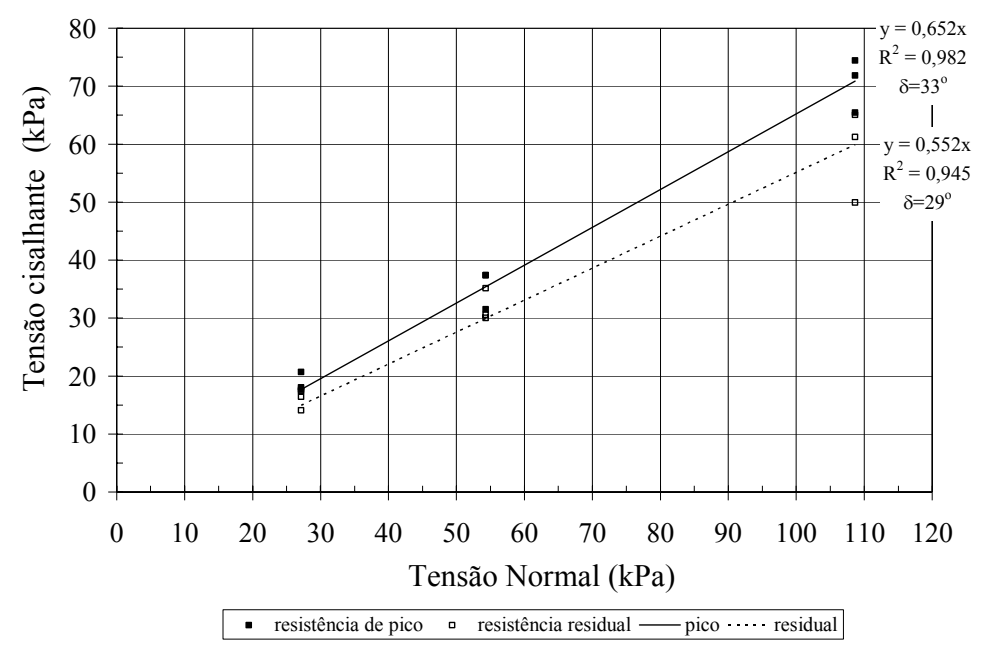

Figura 4.2.2.3. Envoltória de resistência- PVC/areia- CR=100\%.

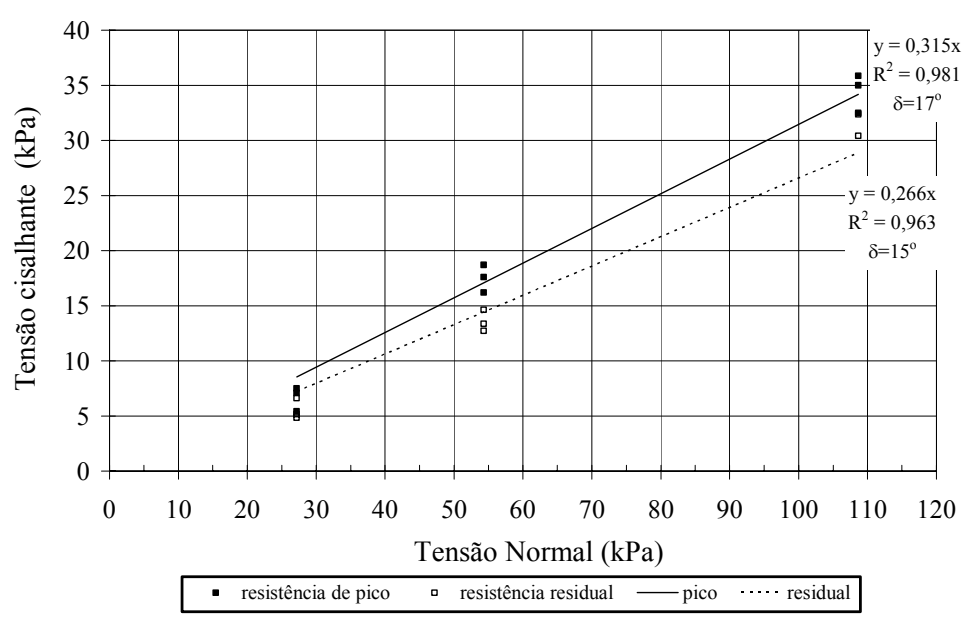

Figura 4.2.2.4. Envoltória de resistência- $P E A D$ lisa/areia- $C R=0 \%$.

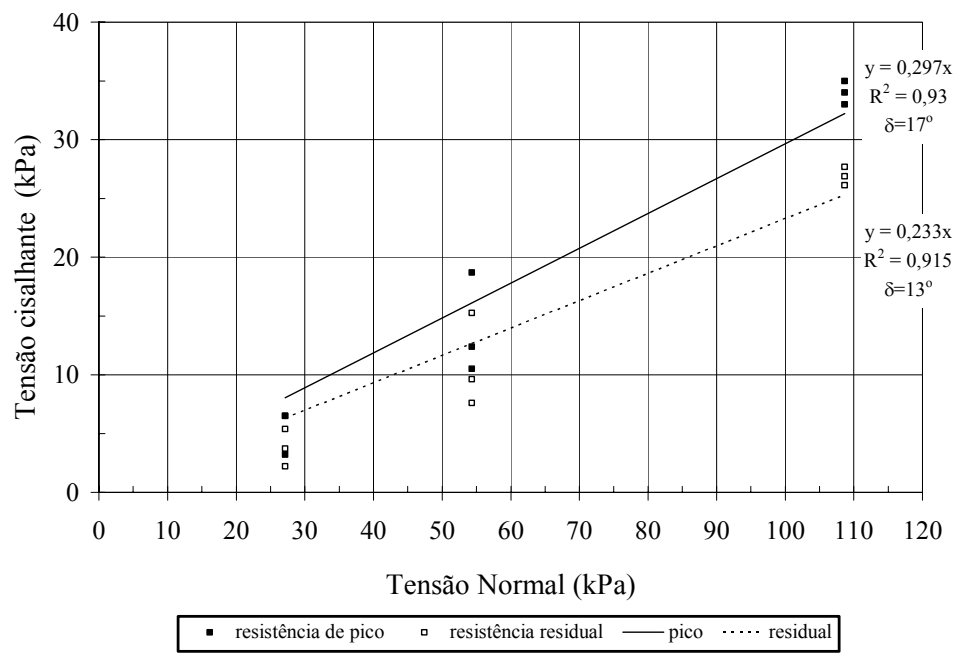

Figura 4.2.2.5. Envoltória de resistência- $P E A D$ lisa/areia- $C R=57 \%$. 


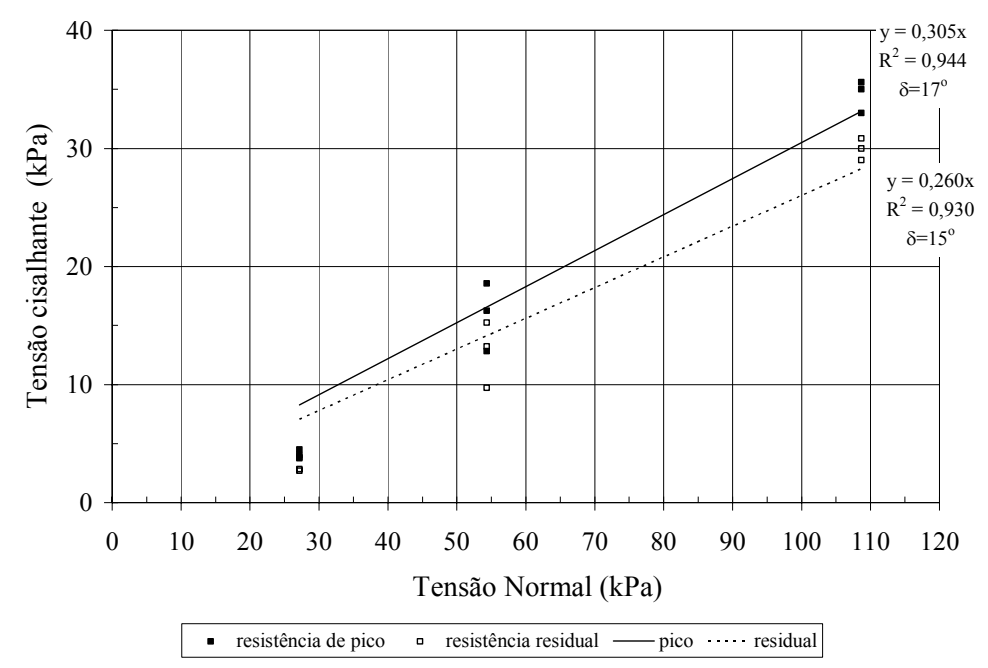

Figura 4.2.2.6. Envoltória de resistência- PEAD lisa/areia- $C R=100 \%$.

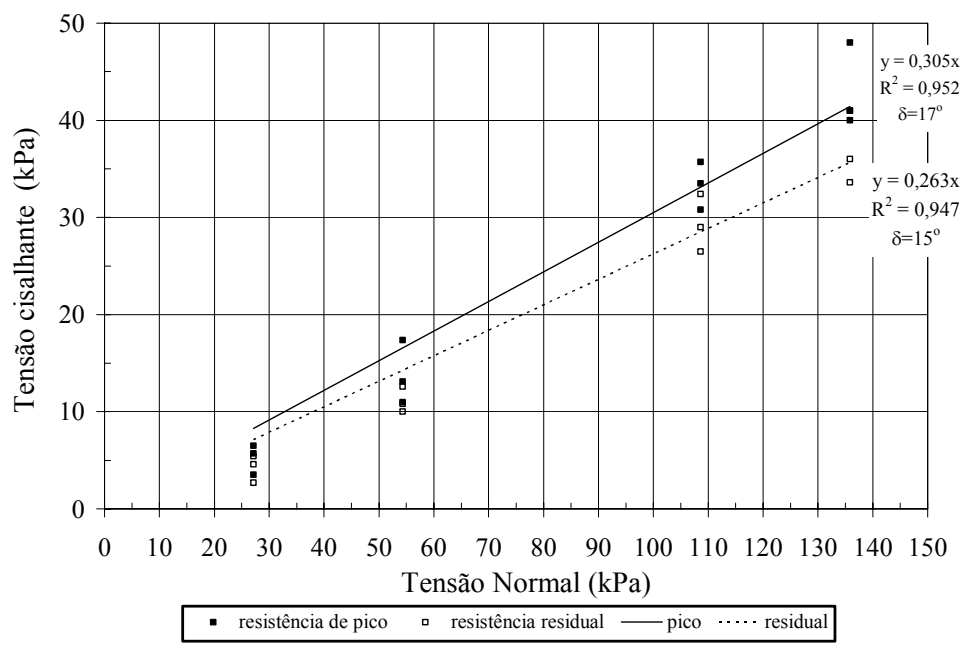

Figura 4.2.2.7. Envoltória de resistência- $P E$ linear/areia- $C R=0 \%$.

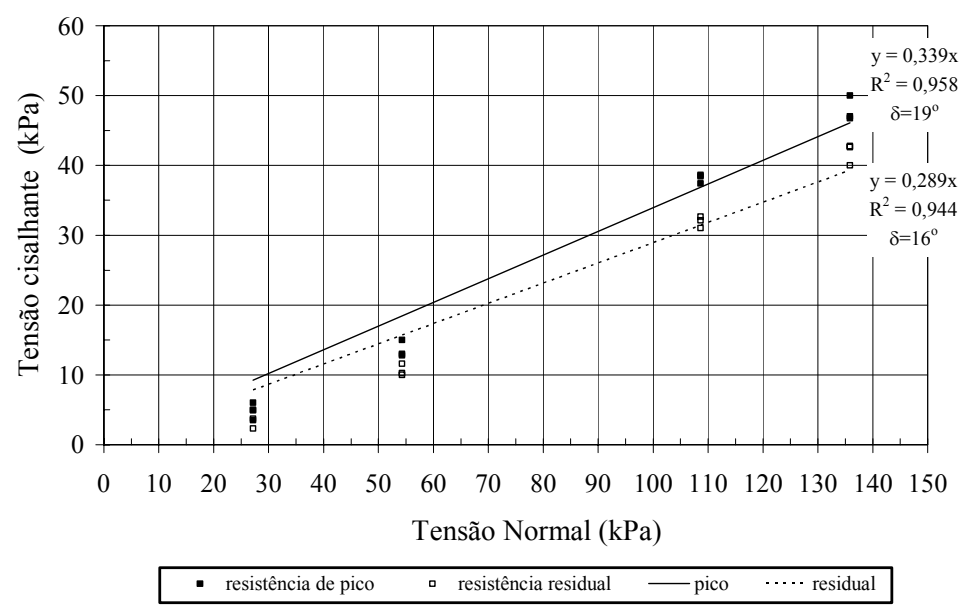

Figura 4.2.2.8. Envoltória de resistência- $P E$ linear/areia- $C R=57 \%$. 


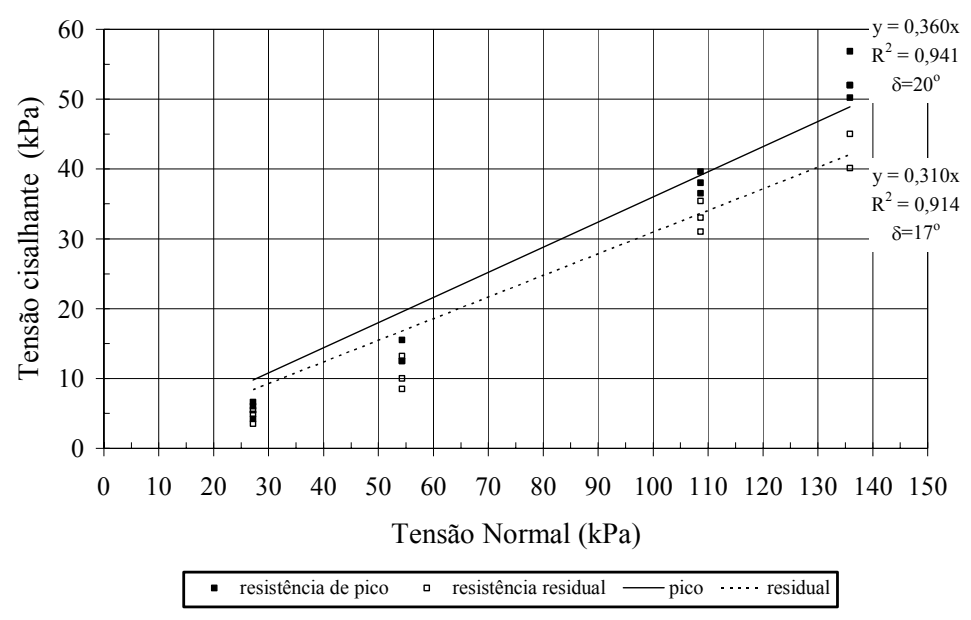

Figura 4.2.2.9. Envoltória de resistência- $P E$ linear/areia- $C R=100 \%$.

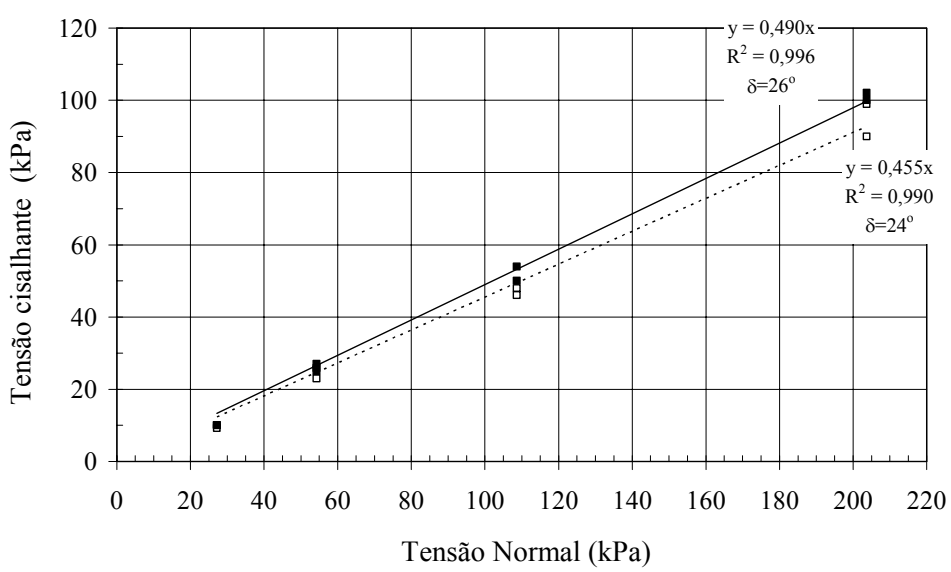

\begin{tabular}{|lllll|}
\hline - resistência de pico & $\square$ & resistência residual & - & \\
\hline
\end{tabular}

Figura 4.2.2.10. Envoltória de resistência- $P E A D$ A/areia- $C R=0 \%$.

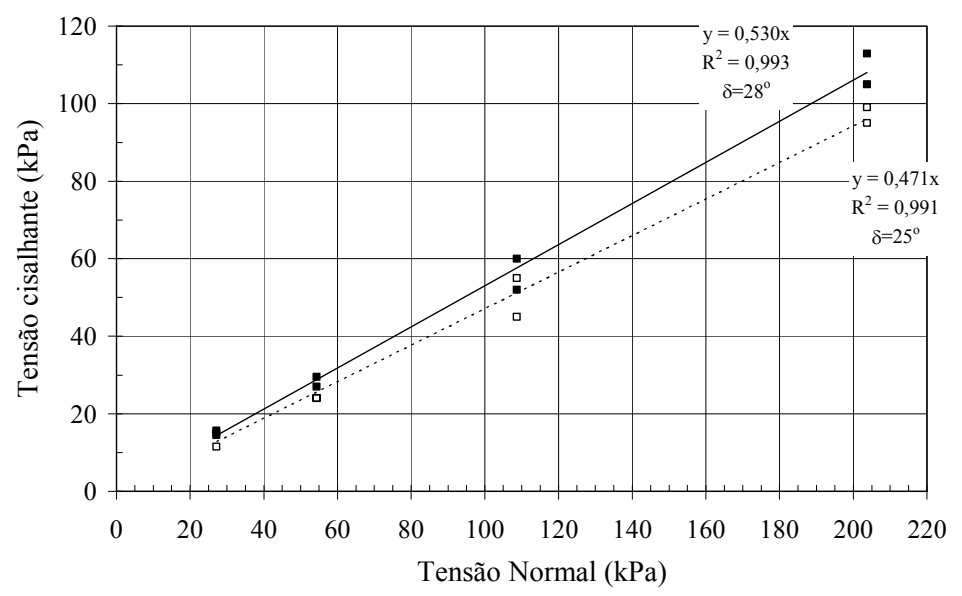

- resistência de pico $\quad$ a resistência residual $\longrightarrow$ pico $\cdots \cdot$ residual

Figura 4.2.2.11. Envoltória de resistência- PEAD A/areia- $C R=57 \%$. 


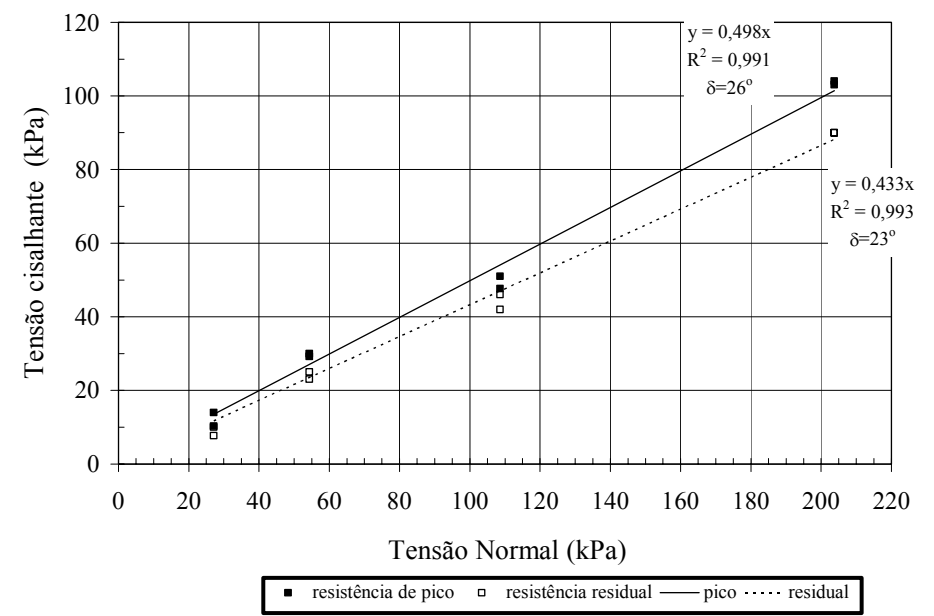

Figura 4.2.2.12. Envoltória de resistência- $P E A D A /$ areia- $C R=100 \%$.

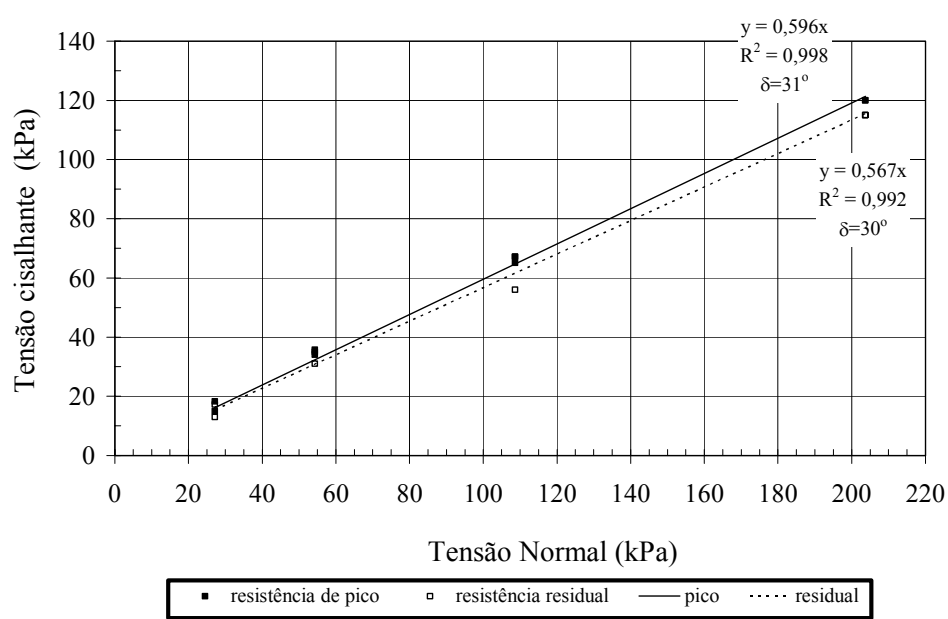

Figura 4.2.2.13. Envoltória de resistência- $P E A D A R /$ areia- $C R=0 \%$.

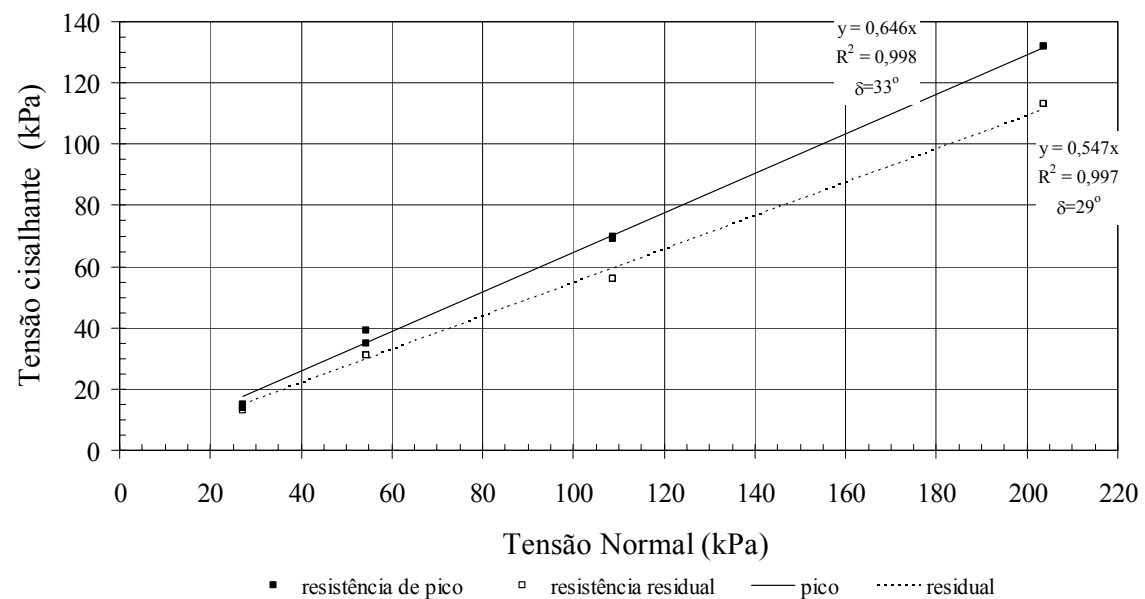

Figura 4.2.2.14. Envoltória de resistência- $P E A D A R / a r e i a-C R=57 \%$. 


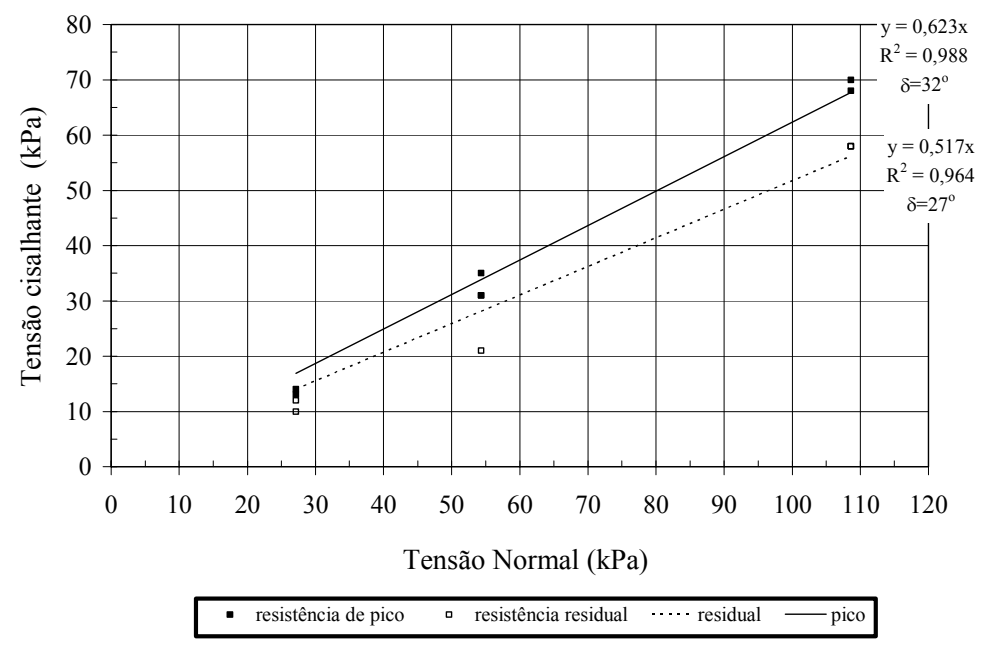

Figura 4.2.2.15. Envoltória de resistência- $P E A D A R /$ areia- $C R=100 \%$.

Tabela 4.2.2.1. Síntese- Ângulos de atrito de interface entre a areia e diferentes geomembranas.

\begin{tabular}{|c|c|c|c|c|c|c|c|}
\hline \multirow{4}{*}{\multicolumn{2}{|c|}{ Geomembrana }} & \multicolumn{6}{|c|}{ Compacidade da areia } \\
\hline & & \multirow{2}{*}{\multicolumn{2}{|c|}{$\begin{array}{l}C R=0 \% \\
\left.(\phi=29)^{\circ}\right)\end{array}$}} & \multirow{2}{*}{\multicolumn{2}{|c|}{$\begin{array}{c}C R=57 \% \\
\left(\phi=34^{\circ}\right)\end{array}$}} & \multirow{2}{*}{\multicolumn{2}{|c|}{$\begin{array}{c}C R=100 \% \\
\left(\phi=37^{\circ}\right)\end{array}$}} \\
\hline & & & & & & & \\
\hline & & $\delta p$ & $\delta r$ & $\delta \mathbf{p}$ & $\delta r$ & $\delta p$ & $\delta r$ \\
\hline \multirow[t]{3}{*}{ PVC } & $1^{a}$ série & $30^{\circ}(1,03)$ & $29^{\circ}(1,00)$ & $31^{\circ}(0,91)$ & $28^{\circ}(0,82)$ & $34^{\circ}(0,87)$ & $31^{\circ}(0,84)$ \\
\hline & $2^{a}$ série & $32^{\circ}(1,11)$ & $30^{\circ}(1,04)$ & $30^{\circ}(0,88)$ & $28^{\circ}(0,82)$ & $35^{\circ}(0,95)$ & $29^{\circ}(0,78)$ \\
\hline & $3^{a}$ série & $31^{\circ}(1,08)$ & $29^{\circ}(1,00)$ & $30^{\circ}(0,88)$ & $28^{\circ}(0,82)$ & $31^{\circ}(0,84)$ & $26^{\circ}(0,70)$ \\
\hline \multicolumn{2}{|c|}{ Valores médios } & $31^{\circ}(1,07)$ & $29^{\circ}(1,00)$ & $30^{\circ}(0,88)$ & $28^{\circ}(0,82)$ & $33^{\circ}(0,89)$ & $29^{\circ}(0,78)$ \\
\hline PEAD & $1^{a}$ série & $18^{\circ}(0,62)$ & $15^{\circ}(0,52)$ & $16^{\circ}(0,47)$ & $13^{\circ}(0,38)$ & $170(0,46)$ & $14^{\circ}(0,38)$ \\
\hline \multirow[t]{2}{*}{ lisa } & $2^{a}$ série & $17^{\circ}(0,59)$ & $13^{\circ}(0,48)$ & $17^{\circ}(0,50)$ & $14^{\circ}(0,41)$ & $170(0,46)$ & $15^{\circ}(0,41)$ \\
\hline & $3^{a}$ série & $18^{\circ}(0,62)$ & $16^{\circ}(0,55)$ & $16^{\circ}(0,47)$ & $13^{\circ}(0,38)$ & $170(0,46)$ & $15^{\circ}(0,41)$ \\
\hline \multicolumn{2}{|c|}{ Valores médios } & $17^{\circ}(0,59)$ & $15^{\circ}(0,52)$ & $17^{\circ}(0,50)$ & $13^{\circ}(0,38)$ & $17^{\circ}(0,46)$ & $15^{\circ}(0,41)$ \\
\hline \multirow[t]{3}{*}{ PELMD } & $1^{a}$ série & $17 \circ(0,59)$ & $15^{\circ}(0,52)$ & $190(0,56)$ & $160(0,47)$ & $20 \circ(0,54)$ & $17 \circ(0,46)$ \\
\hline & $2^{a}$ série & $15^{\circ}(0,52)$ & $13^{\circ}(0,45)$ & $19 \circ(0,56)$ & $16^{\circ}(0,47)$ & $21^{\circ}(0,57)$ & $19^{\circ}(0,51)$ \\
\hline & $3^{a}$ série & $18^{\circ}(0,62)$ & $16^{\circ}(0,55)$ & $19 \circ(0,56)$ & $16^{\circ}(0,47)$ & $19^{\circ}(0,51)$ & $16^{\circ}(0,43)$ \\
\hline \multicolumn{2}{|c|}{ Valores médios } & $17^{\circ}(0,59)$ & $15^{\circ}(0,52)$ & $19^{\circ}(0,56)$ & $16^{\circ}(0,47)$ & $20^{\circ}(0,54)$ & $17^{\circ}(0,46)$ \\
\hline \multirow[t]{2}{*}{ PEAD A } & $1^{a}$ série & $26^{\circ}(0,90)$ & $25^{\circ}(0,86)$ & $28^{\circ}(0,82)$ & $23^{\circ}(0,68)$ & $26^{\circ}(0,70)$ & $23^{\circ}(0,62)$ \\
\hline & $2^{a}$ série & $26^{\circ}(0,90)$ & $24^{\circ}(0,83)$ & $28^{\circ}(0,82)$ & $24 \circ(0,70)$ & $27^{\circ}(0,73)$ & $24^{\circ}(0,65)$ \\
\hline \multicolumn{2}{|c|}{ Valores médios } & $26^{\circ}(0,90)$ & $24^{\circ}(0,83)$ & $28^{\circ}(0,82)$ & $25^{\circ}(0,73)$ & $26^{\circ}(0,70)$ & $23^{\circ}(0,62)$ \\
\hline \multirow{2}{*}{\multicolumn{2}{|c|}{ PEAD AR }} & $31^{\circ}(1,07)$ & $29 \circ(1,00)$ & $33^{\circ}(0,97)$ & $29 \circ(0,85)$ & $33^{\circ}(0,89)$ & $28^{\circ}(0,76)$ \\
\hline & & $31^{\circ}(1,07)$ & $30^{\circ}(1,03)$ & $33^{\circ}(0,97)$ & $29 \circ(0,85)$ & $31^{\circ}(0,84)$ & $26^{\circ}(0,70)$ \\
\hline \multicolumn{2}{|c|}{ Valores médios } & $31^{\circ}(1,07)$ & $30^{\circ}(1,03)$ & $33^{\circ}(0,97)$ & $29^{\circ}(0,85)$ & $32^{\circ}(0,86)$ & $27^{\circ}(0,73)$ \\
\hline
\end{tabular}

${ }^{*}$ ) Valores entre parênteses (eficiência) baseados na relação $\delta / \phi$ 
Com base nestes resultados, verificou-se que as envoltórias de resistência são aproximadamente lineares para todas as interfaces analisadas, com elevados valores de $r^{2}$ e com intercepto de coesão nulo.

A partir da Tabela 4.2.2.1, verifica-se que os resultados obtidos são semelhantes aos reportados por O'Rourke et al. (1990) e Koerner (1994). O'Rourke et al. (1990) constataram ângulos de atrito de pico de $30^{\circ} \mathrm{em}$ interface com geomembrana de PVC e areia. Em interfaces com geomembranas de PEAD lisa, obtiveram ângulos de atrito de 190. Neste trabalho, foram realizados ensaios de cisalhamento direto com areia padrão (Otawa), com ângulo de atrito interno igual a 350, e variações de peso específico entre 16,5 a $17,0 \mathrm{kN} / \mathrm{m}^{3}$.

De acordo com Koerner (1994), os ângulos de atrito de pico sugeridos para interfaces PVC/areia para concreto e PVC/areia micácea foram $25^{\circ}$ (eficiência de 0,81) e $21^{\circ}$ (eficiência de 0,79), respectivamente. Para as geomembranas de PEAD lisa, são sugeridos valores de $18^{\circ}$ (eficiência de 0,56 ), $18^{\circ}$ (eficiência de 0,61) e 170 (eficiência de 0,63), relativamente às areias para concreto, Otawa e micácea. Os valores de ângulos de atrito de pico obtidos nas geomembranas texturizadas estão dentro da faixa de variação sugerida por Bouazza et al. (2002) (30॰ a 45).

Através da Tabela 4.2.2.1 pôde-se verificar a influência da compacidade da areia na resistência de interface. Nas interfaces com geomembranas de PVC, obteve-se uma variação de dois graus do estado mínimo de compacidade para o estado máximo, e nas geomembranas de PELMD a variação foi equivalente a três graus. Nas interfaces com geomembranas de PEAD lisa não se verificou variação nos ângulos de atrito de pico com a compacidade da areia. Nas interfaces com geomembranas texturizadas, verificou-se um aumento de dois graus do estado mínimo para o estado medianamente compacto da areia, e uma diminuição de um grau do estado mediamente compacto para o compacto. Constatou-se que a variação na resistência é bem pequena, o que pode ser considerada desprezível. Concluiu-se que, para o material granular estudado, a compacidade da areia não interfere nas propriedades de tensão cisalhante em interfaces. 
O'Rourke et al. (1990) estudaram, através de ensaios de cisalhamento direto com geomembranas de PVC e PEAD e diferentes tipos de areias, 0 efeito da compacidade na resistência de interface. Observaram que a correlação entre a resistência de interface e a compacidade da areia depende das características da areia como angularidade, tamanho e composição mineralógica dos grãos, fatores estes que não foram variados no trabalho apresentado.

No entanto, é importante enfatizar que, com a aplicação da carga normal, ocorre uma mudança no estado de densidade inicial da areia, principalmente nas areias fofas, e conseqüentemente na resistência interna da mesma. Como a eficiência é baseada na relação entre o ângulo de atrito de interface e o ângulo de atrito interno, devem ser considerados com certa cautela os valores de eficiência maiores do que um.

\subsubsection{Efeito do tipo das geomembranas}

As envoltórias apresentadas nas Figuras 4.2.2.1.1 e 4.2.2.1.2 avaliam o efeito do tipo da geomembrana sobre a tensão cisalhante em interfaces envolvendo geomembranas de PVC (mais flexíveis), geomembranas de PEAD (mais rígidas) e geomembranas de PE linear (características intermediárias de rigidez). Tais envoltórias se referem as curvas representativas apresentadas no subitem 4.2.1, e ao material com CR igual a $57 \%$.

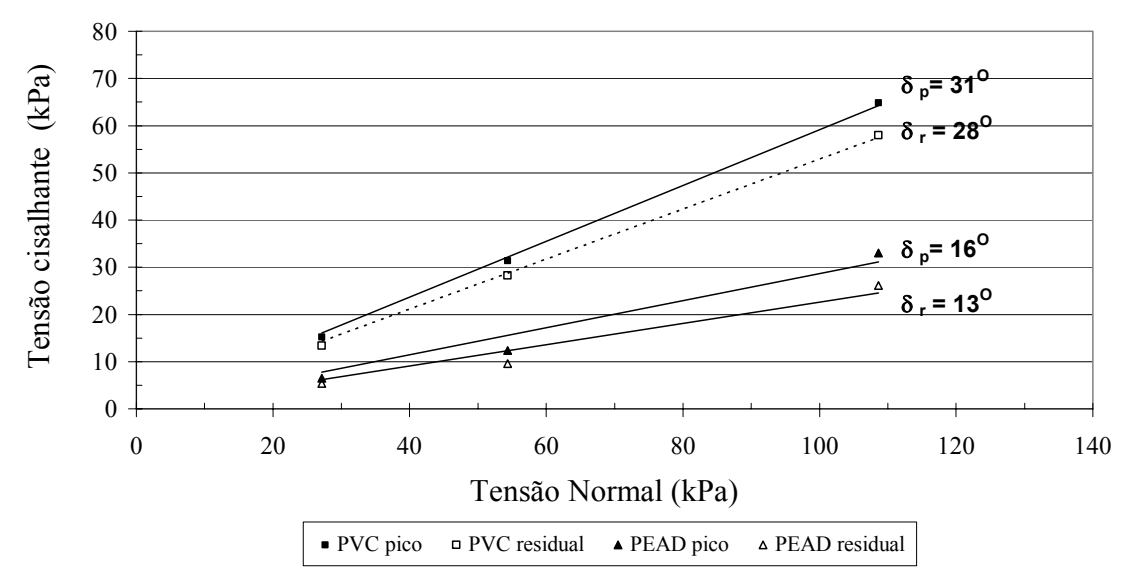

Figura 4.2.2.1.1. Efeito do tipo de geomembrana- $P V C / P E A D-C R=57 \%$. 


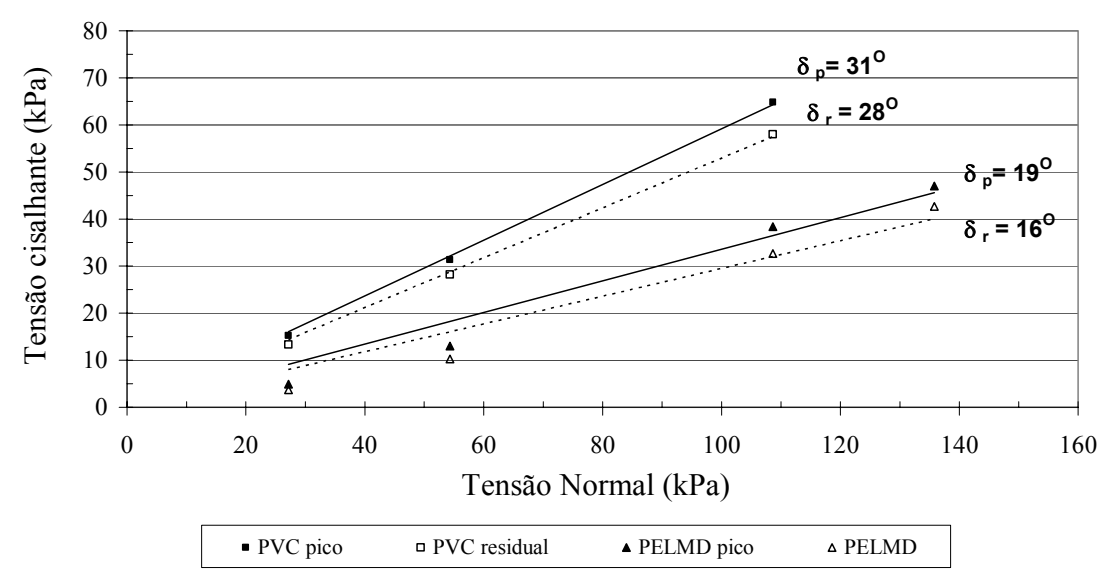

Figura 4.2.2.1.2. Efeito do tipo de geomembrana- $\mathrm{PVC} / \mathrm{PE}$ linear- $\mathrm{CR}=57 \%$.

Concluiu-se que, para interfaces envolvendo materiais granulares, as geomembranas de PE linear e PEAD (mais rígidas), apresentaram menores valores nos ângulos de atrito do que as de PVC. Averigüou-se ainda que nas geomembranas de PE linear os ângulos de atrito obtidos foram ligeiramente maiores do que os da geomembrana de PEAD lisa. Isto pode ser explicado pelos aspectos intermediários de rigidez em relação às geomembranas de PVC e PEAD.

O'Rourke et al. (1990) explicam que este efeito se deve ao mecanismo de transferência de tensões cisalhantes de acordo com a rigidez da geomembrana. Em geomembranas relativamente rígidas, ocorre o mecanismo de deslizamento dos grãos de areia sobre a superfície; enquanto em geomembranas flexíveis, ocorre o mecanismo de rolamento dos grãos. Este último mecanismo induz a concentrações de tensões, que são responsáveis pelos elevados ângulos de atrito, e que ocorrem devido à indentação dos grãos com a geomembrana.

Para visualizar o efeito deste mecanismo, foram feitas fotografias com microscópio eletrônico sobre a superfície cisalhada, as quais são apresentadas na Figura 4.2.2.1.3, correspondentes às geomembranas de PVC, PE linear e PEAD lisa. Nota-se que nas geomembranas de PVC existe o efeito de indentação, o qual é temporário e sem marcas permanentes sobre a superfície. Nas geomembranas de PEAD e PE linear podem ser observados estriamentos sobre a superfície, atribuídos ao deslizamento dos grãos. 


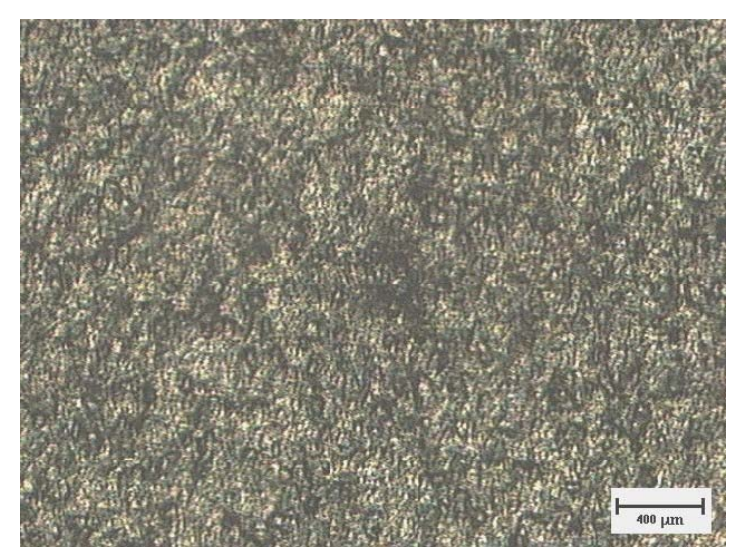

(a) PVC virgem

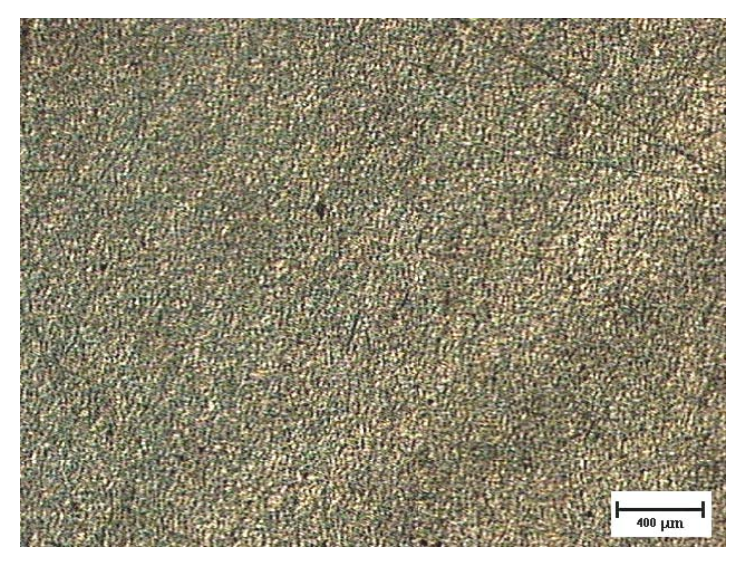

(b) PE linear virgem

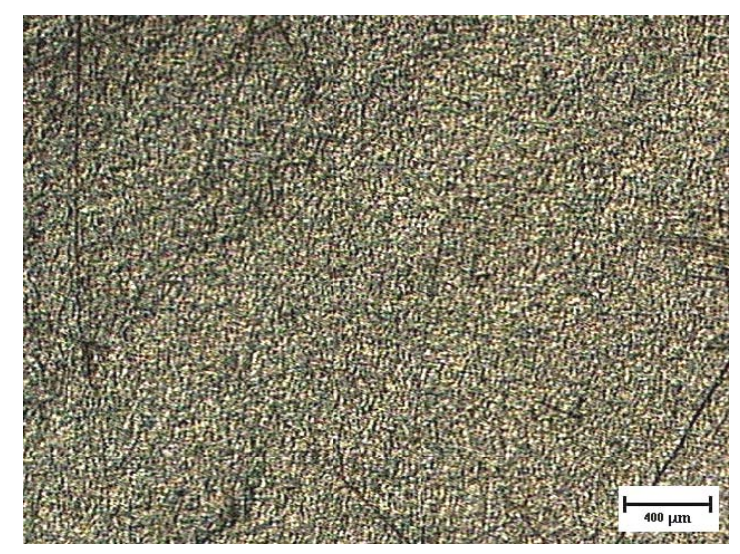

(c) PEAD virgem

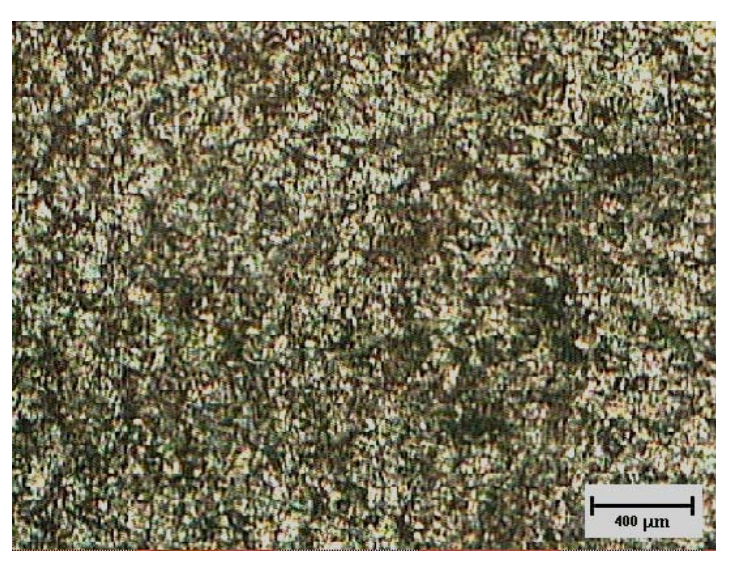

(a) PVC cisalhada

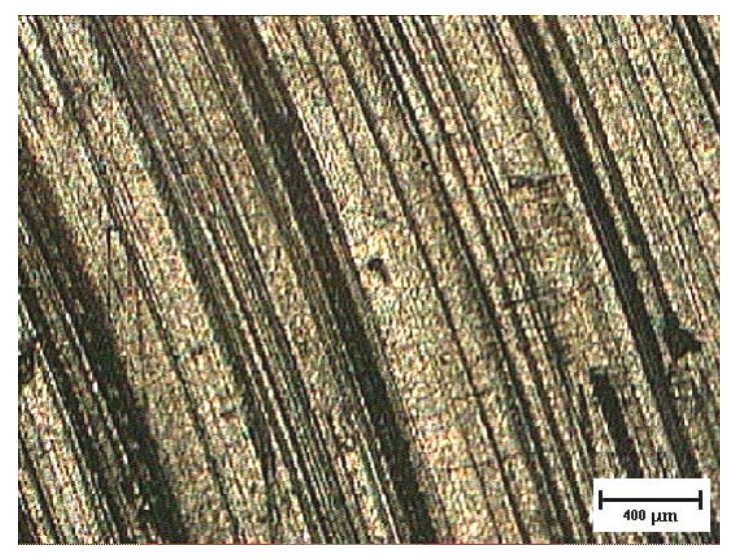

(b) PE linear cisalhada

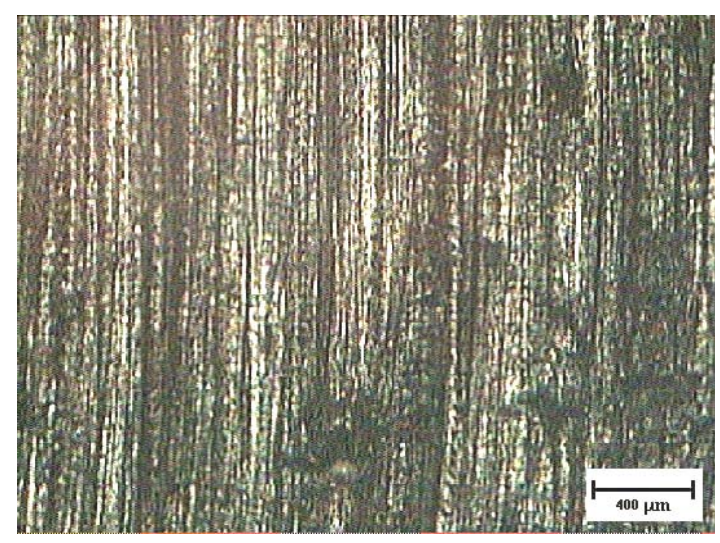

(c) PEAD cisalhada

Figura 4.2.2.1.3. Mecanismo de transferência de tensões cisalhantes- (a) PVC;

(b) PE linear; (c) PEAD lisa. 


\subsubsection{Influência da rugosidade das geomembranas}

Outro fator que interfere nas propriedades de atrito em interfaces geomembranas/materiais granulares corresponde à rugosidade ou textura da geomembrana. Para verificar tal efeito são apresentadas, nas figuras abaixo, as envoltórias de resistências em geomembranas de PEAD lisas e geomembranas de PEAD texturizadas dos tipos $A$ e $A R$, relativas à areia com $\mathrm{CR}=57 \%$.

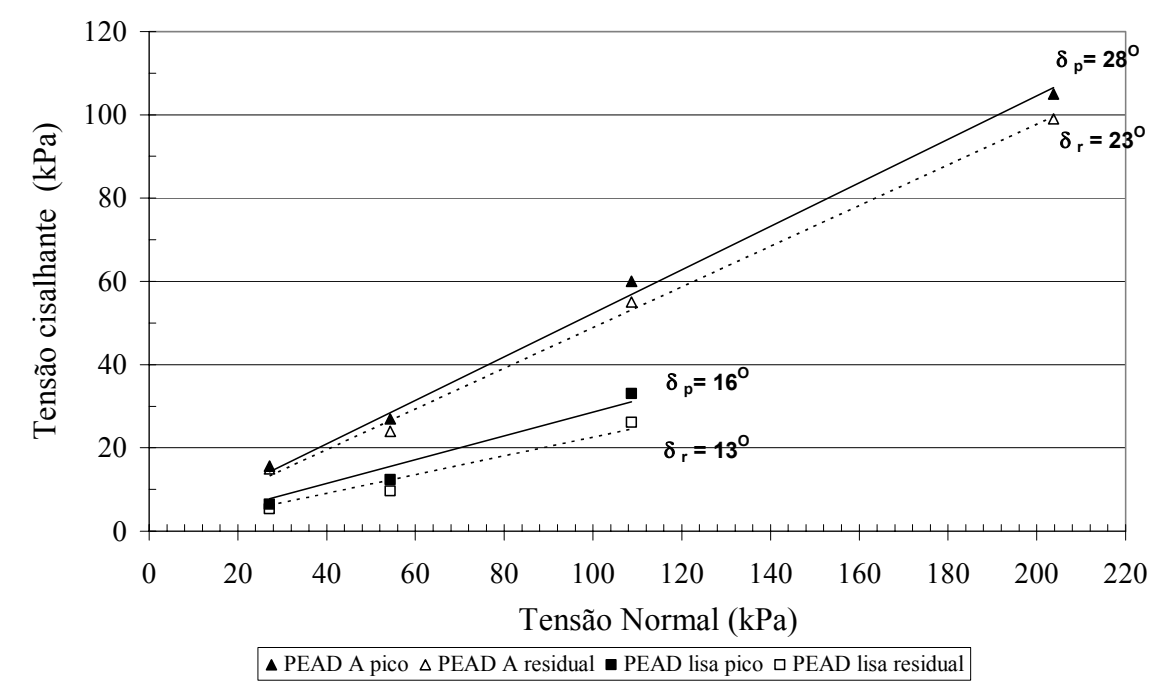

Figura 4.2.3.1. Influência da textura- Comparação entre PEAD e PEAD A.

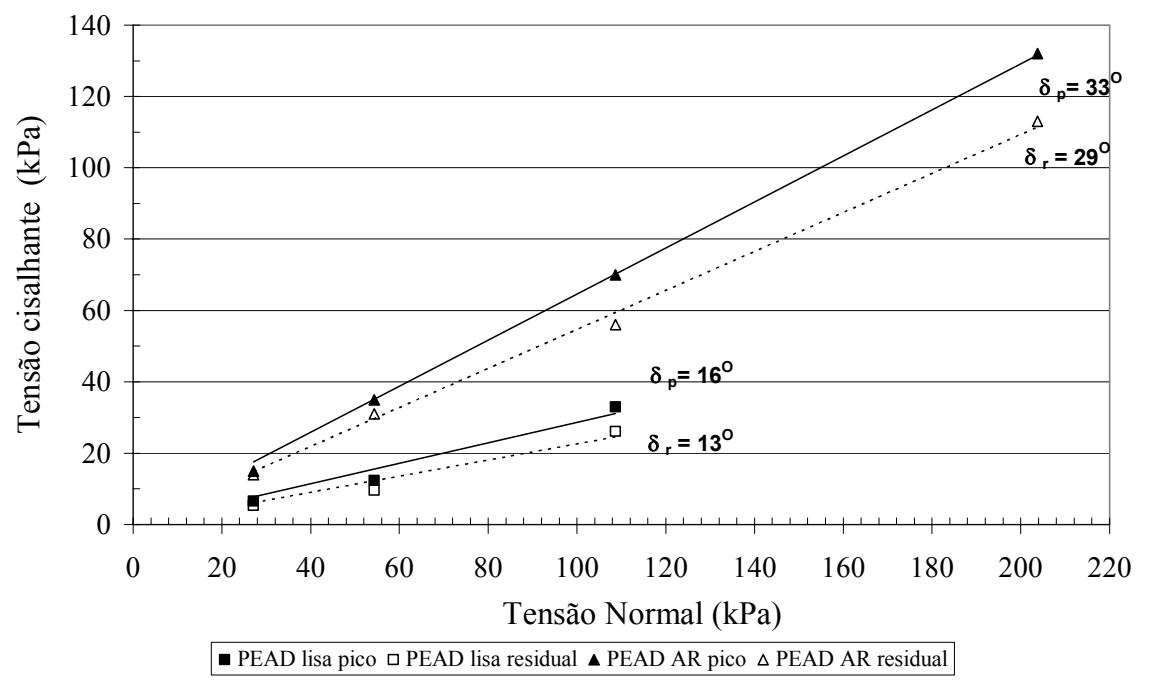

Figura 4.2.3.2. Influência da textura- Comparação entre PEAD e PEAD AR.

Observou-se que em interfaces envolvendo materiais granulares, a rugosidade da geomembrana contribui significantemente para o aumento de 
resistência. Comparando estes resultados, verificou-se um acréscimo de aproximadamente $50 \%$ no ângulo de atrito de pico e residual nas geomembranas de PEAD-A em relação às de PEAD-lisa.

Conforme verificado na Figura 4.2.4.2, as geomembranas de PEAD AR também contribuíram para o aumento das características de atrito. Além disto, apresentaram valores de ângulos de atrito significativamente maiores do que observados nas geomembranas de PEAD lisa (aproximadamente $80 \%$ ). Isto pode ser creditado às saliências existentes nestas geomembranas, as quais propiciaram um forte entrosamento com os grãos de areia, e conseqüentemente elevado atrito.

\subsubsection{Condição de umidade dos materiais}

De acordo com Pasqualini et al. (1993) e Masada et al. (1994), existem condições ambientais particulares, como a umidade devido à percolação do chorume e à ação da chuva, que interferem nas propriedades de resistência de interface.

Masada et al. (1994) verificaram que a tensão cisalhante depende das características do líquido em contato com as geomembranas. Através de ensaios de cisalhamento direto, observaram que os ângulos de atrito obtidos nos materiais saturados com água são menores do que nos saturados com chorume. Estes autores sugerem que este aspecto é atribuído às características de viscosidade dos líquidos percolados, responsáveis pelo aumento de atrito em relação à água.

Para verificar tal efeito, a segunda série de ensaios do programa consistiu em ensaiar os materiais em condição saturada. Para isto a areia foi moldada com compacidade relativa igual a 0\%. A Figura 4.2.4.1 apresenta os resultados referentes à interface areia/PVC sob condição saturada. 

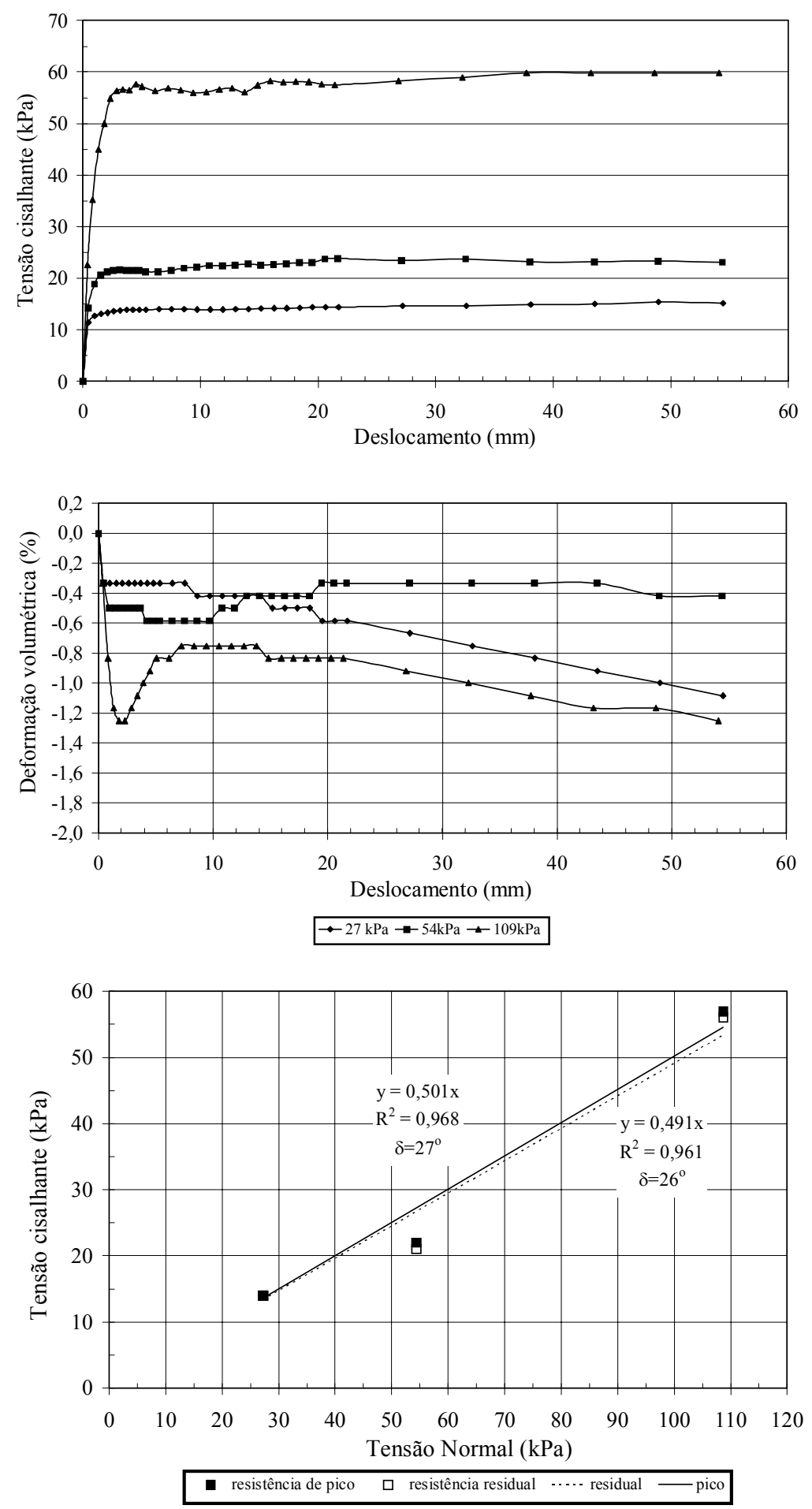

Figura 4.2.4.1. Resultados da interface areia/PVC - condição saturada.

Comparando-se as curvas de tensão cisalhante versus deslocamento com as obtidas em condição seca (Figura 4.2.1.4), observou-se que a tensão cisalhante de pico é mobilizada para deslocamentos de 2 a $4 \mathrm{~mm}$, deslocamentos estes maiores do que os observados na condição seca (entre 1,5 a 2,5mm). Constatou-se ainda que a tensão cisalhante de pico é 
aproximadamente igual à tensão residual no ensaio saturado; enquanto no ensaio seco, verificou-se uma queda de tensão cisalhante pós-pico. Na Figura 4.2.4.2 são apresentados os resultados dos ensaios realizados na interface areia/PEAD em condição saturada, também com CR igual a $0 \%$.
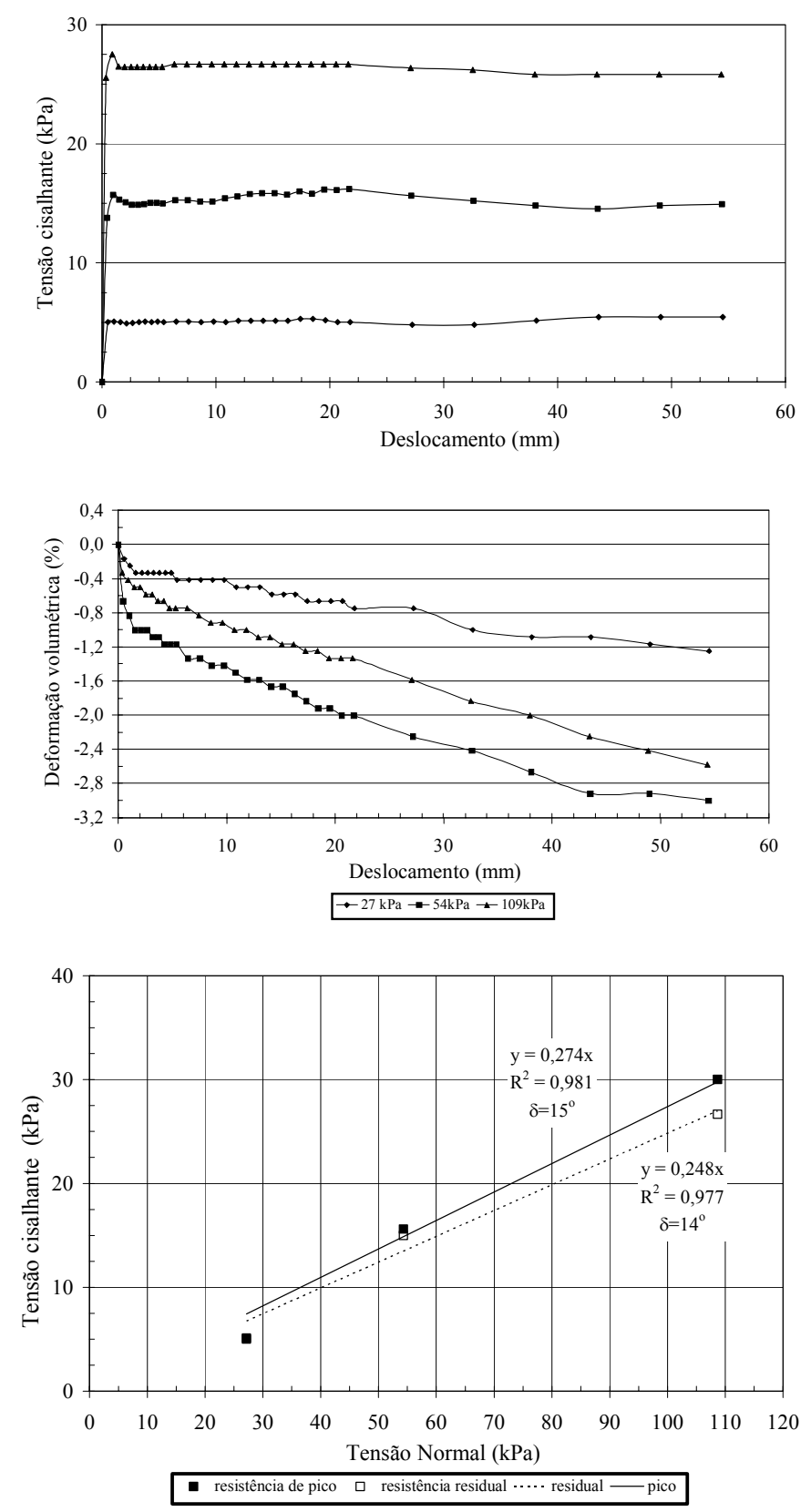

Figura 4.2.4.2. Resultados da interface areia/PEAD condição saturada.

Comparando os resultados acima com os obtidos na Figura 4.2.1.4 (condição seca), observou-se que as tensões cisalhantes de pico e residual são mobilizadas com os mesmos deslocamentos nas condições de pico e residual. Entretanto, pôde-se constatar que a perda de tensão cisalhante póspico é menor nos ensaios saturados. Foram obtidas quedas de tensão de 
aproximadamente $2 \%, 4 \%$ e $11 \%$ para os carregamentos de $27 \mathrm{kPa}, 54 \mathrm{kPa}$ e $109 \mathrm{kPa}$, respectivamente, no ensaio inundado; enquanto no ensaio seco os valores foram $7 \%, 22 \%$ e $13 \%$. A Figura 4.2 .4 .3 se refere aos ensaios saturados com interface areia/PELMD.

Comparando-se os resultados apresentados na Figura 4.2.4.3 com os resultados dos ensaios secos (Figura 4.2.1.7), observou-se que os deslocamentos mobilizados para a condição de pico são semelhantes em ambas as condições de ensaio. Constatou-se também que a perda de tensão cisalhante pós-pico é menor no ensaio saturado. Foram obtidas para esta interface perdas aproximadamente iguais a $8 \%, 13 \%, 11 \%$ e $10 \%$ para carregamentos de $27 \mathrm{kPa}, 54 \mathrm{kPa}, 109 \mathrm{kPa}$ e $136 \mathrm{kPa}$. Por sua vez, no ensaio seco os valores obtidos foram 12\%, $18 \%, 17 \%$ e $16 \%$.

Na Figura 4.2.4.4 são apresentados os resultados referentes à interface areia/PEAD A. Verificou-se que a perda de tensão cisalhante pós-pico é bem pequena nos ensaios saturados, com quedas em torno de $0 \%, 2 \%, 4 \%$ e $2 \%$ para os carregamentos de $27 \mathrm{kPa}, 54 \mathrm{kPa}, 109 \mathrm{kPa}$ e $204 \mathrm{kPa}$, respectivamente. Nos ensaios secos foram obtidas perdas de $0 \%, 8 \%, 11 \%$ e $3 \%$. Quanto aos deslocamentos, observou-se que nos ensaio saturados a tensão cisalhante de pico foi mobilizada para deslocamentos maiores do que na condição seca. Enquanto no ensaio seco foi mobilizada para deslocamentos em torno de 2,0 a 4,0mm, no ensaio saturado foi mobilizada entre $4,0 \mathrm{~mm}$ e $6,0 \mathrm{~mm}$ de deslocamento. 

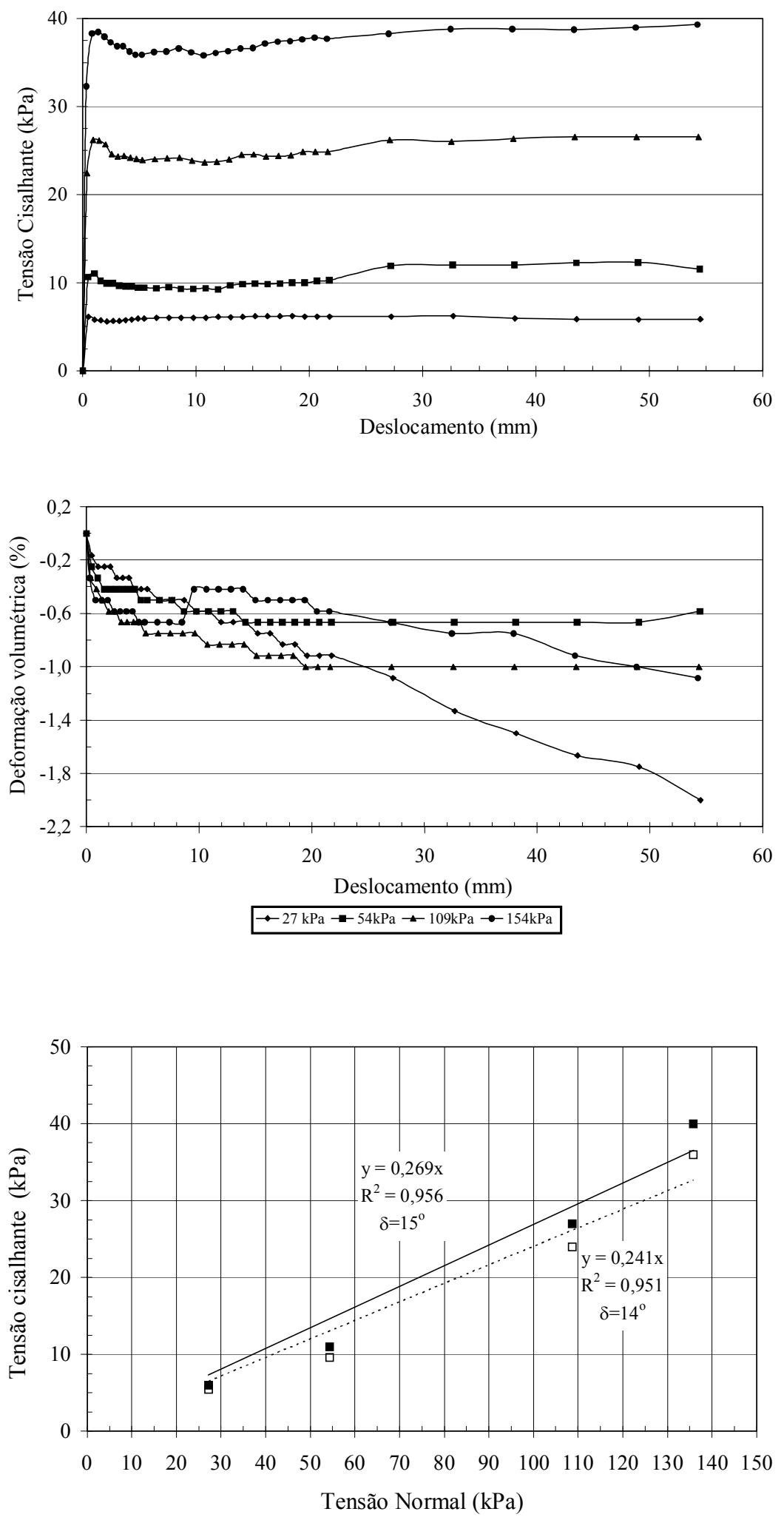

- resistênnia de pico $\square$ resistência residual $\cdots$... residual $~ —$ pico

Figura 4.2.4.3. Resultados da interface areia/PELMD- condição saturada. 

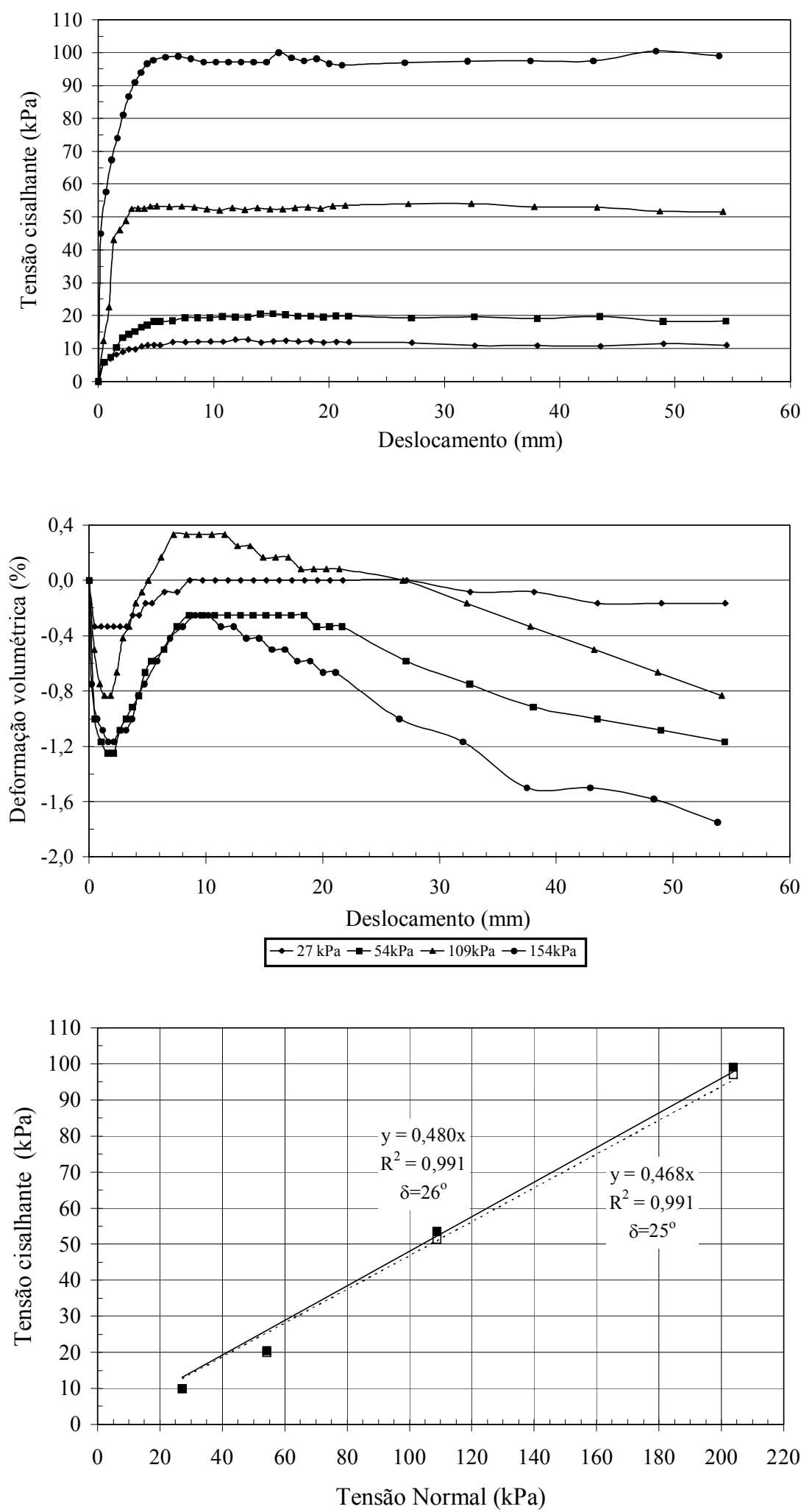

- resistência de pico $\square$ resistência residual $\cdots \cdot$ residual $\longrightarrow$ pico

Figura 4.2.4.4. Resultados da interface areia/PEAD A- condição saturada. 
A Figura 4.2.4.5 apresenta os resultados de interface referentes ao ensaio saturado com geomembrana de PEAD AR.
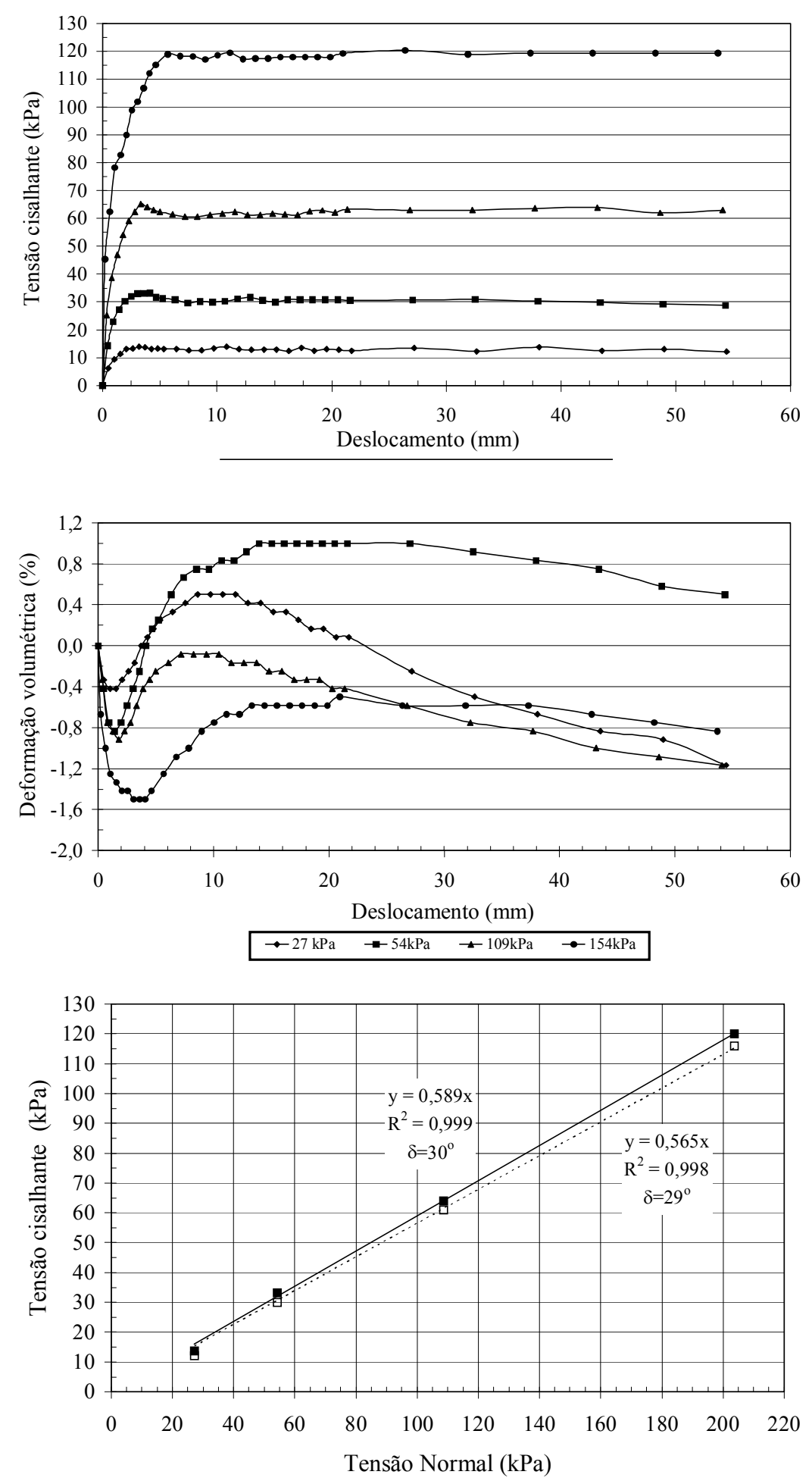

- resistência de pico $\quad \square \quad$ resistência residual $\cdots$... residual $—$ pico

Figura 4.2.4.5. Resultados da interface areia/PEAD AR- condição saturada. 
Com base na Figura 4.2.4.5, verificou-se que, para os ensaios saturados com geomembranas de PEAD AR, a tensão cisalhante de pico é aproximadamente igual à residual, mesmo para carregamentos mais elevados (204kPa). Nos ensaios secos, percebeu o mesmo comportamento, contudo para o carregamento de $204 \mathrm{kPa}$, a perda de tensão cisalhante foi maior do que observado no ensaio saturado. Quanto aos deslocamentos, observou-se que as tensões cisalhantes de pico em ambos os ensaios foram mobilizados com a mesma ordem de grandeza de deslocamentos, em torno de 2,0 a $4,0 \mathrm{~mm}$. Porém, a tensão cisalhante residual no ensaio saturado foi mobilizada com deslocamentos menores, em torno de $10 \mathrm{~mm}$ aproximadamente.

Na Tabela 4.2.4.1 é apresentada uma comparação entre os ângulos de atrito de pico e residual obtidos nos ensaios seco e saturado. Os valores de atrito na condição seca se referem aos valores médios das repetições dos ensaios, realizados com CR de $0 \%$.

Tabela 4.2.4.1. Comparação entre os ensaios realizados em condição seca e úmida.

\begin{tabular}{|l|c|c|c|c|}
\hline \multirow{2}{*}{ Interface } & \multicolumn{2}{|c|}{ Condição seca } & \multicolumn{2}{c|}{ Condição úmida } \\
\cline { 2 - 5 } & $\tau$ pico & $\tau$ residual & $\tau$ pico & $\tau$ residual \\
\hline GM PVC/areia & $31^{\circ}$ & $29 \circ$ & $27^{\circ}$ & $26^{\circ}$ \\
GM PEAD lisa/areia & 170 & $15^{\circ}$ & $15^{\circ}$ & $14^{\circ}$ \\
GM PE linear/ areia & 170 & $15^{\circ}$ & $15^{\circ}$ & $14^{\circ}$ \\
GM PEAD A/areia & $26^{\circ}$ & $24^{\circ}$ & $26^{\circ}$ & $25^{\circ}$ \\
GM PEAD AR/areia & $31^{\circ}$ & $30^{\circ}$ & $30^{\circ}$ & $29 \circ$ \\
\hline
\end{tabular}

Verificou-se que os materiais em condição saturada apresentaram, ângulos de atrito ligeiramente menores do que os ensaiados em condição seca, com exceção das interfaces com geomembranas texturizadas. O efeito da umidade foi mais pronunciado nas geomembranas de PVC, verificando-se uma variação de $4^{\circ}$ no ângulo de atrito de pico, e $3^{\circ}$ no ângulo residual.

Por sua vez, nas demais interfaces, a variação nos ângulos de atrito foi pequena, da ordem de um grau, o que pode ser considerado desprezível. 


\subsubsection{Comparação com ensaios de cisalhamento direto}

Além dos ensaios de ring shear, foram realizados ensaios complementares com caixa de cisalhamento direto. Devido aos pequenos deslocamentos permitidos nas caixas de cisalhamento direto, empregou-se uma base maior para a fixação das geomembranas. Com estas modificações, obtiveram-se deslocamentos até $20 \mathrm{~mm}$. Os resultados dos ensaios de cisalhamento direto e ring shear são apresentados na Tabela 4.2.5.1. Em ambos os resultados, os ensaios foram realizados em condição seca, com corpos de prova moldados com $C R=0 \%, \gamma_{d}=14,6 \mathrm{kN} / \mathrm{m}^{3} ; \mathrm{e}=0,83$.

Tabela 4.2.5.1. Comparação entre os ensaios de cisalhamento.

\begin{tabular}{|c|c|c|c|c|}
\hline \multirow[t]{2}{*}{ Interface } & \multicolumn{2}{|c|}{ Ring shear $\left({ }^{*}\right)$} & \multicolumn{2}{|c|}{ Cisalhamento direto } \\
\hline & $\delta$ pico & Sresidual & $\delta$ pico & Sresidual \\
\hline GM PVC/areia & $31^{\circ}(1,07)$ & $29^{\circ}(1,00)$ & $28^{\circ}(0,88)$ & $27^{\circ}(0,84)$ \\
\hline GM PEAD lisa/areia & $17^{\circ}(0,59)$ & $15^{\circ}(0,52)$ & $18^{\circ}(0,56)$ & $16^{\circ}(0,50)$ \\
\hline GM PE linear/ areia & $17^{\circ}(0,59)$ & $15^{\circ}(0,52)$ & $18^{\circ}(0,56)$ & $16^{\circ}(0,50)$ \\
\hline GM PEAD A/areia & $26^{\circ}(0.90)$ & $24^{\circ}(0,83)$ & $31 \circ(0,97)$ & $27 \circ(0,84)$ \\
\hline GM PEAD AR/areia & $31^{\circ}(1,07)$ & $30^{\circ}(1,03)$ & $31 \circ(0,97)$ & $26 \circ(0,81)$ \\
\hline
\end{tabular}

(*) Valores de ângulos de atrito médios

Verificou-se que os valores de ângulos de atrito obtidos nos ensaios de cisalhamento direto e ring shear são semelhantes, obtendo-se, em geral, uma variação de dois graus. Apenas na interface geomembrana PEAD A/areia que se observou uma maior variação, equivalente a $5^{\circ}$.

As curvas de resistência de interface, de deformação volumétrica e as envoltórias obtidas através do ensaio de cisalhamento direto são apresentadas no Apêndice C. Comparando-se estas curvas com as apresentadas no item 4.2.1, verificou-se que as curvas de tensão cisalhante versus deslocamento obtidas pelo ring shear e pelo cisalhamento direto são semelhantes, apresentando pequenas variações no comportamento em algumas interfaces.

Através dos resultados obtidos por ensaios de cisalhamento direto, observou-se que a tensão cisalhante de pico na interface areia/PVC é 
mobilizada para deslocamentos entre 2 e $7 \mathrm{~mm}$. Observou-se ainda que a tensão cisalhante residual não é tão acentuada, apresentando pequenos decréscimos de resistência pós-pico. Diferentemente, nos ensaios de interface através do ring shear a tensão cisalhante de pico é mobilizada com deslocamentos menores ( 1,5 a 2,5mm), e a perda de tensão pós-pico é maior do que nos ensaios de interface por meio de cisalhamento direto.

Nos resultados de cisalhamento direto com geomembranas de PEAD lisa e PELMD, verificou-se que a tensão cisalhante de pico é mobilizada para deslocamentos entre 1,0 a $1,5 \mathrm{~mm}$. Nos ensaios com ring shear, a tensão cisalhante de pico é mobilizada com deslocamentos entre 0,5 a 1,5mm. As tensões cisalhantes residuais nas geomembranas de PEAD e PELMD são mobilizadas a partir dos $6 \mathrm{~mm}$ de deslocamentos, tanto no ensaio de ring shear quanto no ensaio de cisalhamento direto.

Nos ensaios de cisalhamento direto realizados com geomembranas texturizadas de PEAD A e AR, observou-se mobilização da tensão cisalhante de pico com deslocamentos de $1,0 \mathrm{~mm}$, para o carregamento de $30 \mathrm{kPa}$, e entre $2,0 \mathrm{~mm}$ a $4,0 \mathrm{~mm}$, para os carregamentos de $54 \mathrm{kPa}$ e $113 \mathrm{kPa}$. Nos ensaios com ring shear, o comportamento observado foi semelhante, com exceção do carregamento de $30 \mathrm{kPa}$, onde a tensão de pico é mobilizada com 2,0mm. 


\subsection{ENSAIOS DE RESISTÊNCIA DE INTERFACE ENTRE GEOMEMBRANA E SOLO ARGILOSO}

\subsubsection{Ensaios de Ring Shear}

Nas Figuras 4.3.1.1 e 4.3.1.2 são apresentados os resultados dos ensaios de interface argila/PVC realizados sob condição não inundada e material moldado na umidade ótima ( $W$ ótima $=26,7 \%$ ), e grau de compactação igual a 98\% $\left(\gamma_{d}=15,6 \mathrm{kN} / \mathrm{m}^{3}\right)$. Os ensaios foram realizados com adensamento da amostra sob a tensão normal de interesse e cisalhamento com velocidade de $1,635 \mathrm{~mm} / \mathrm{min}$, tentando representar uma ruptura não drenada.
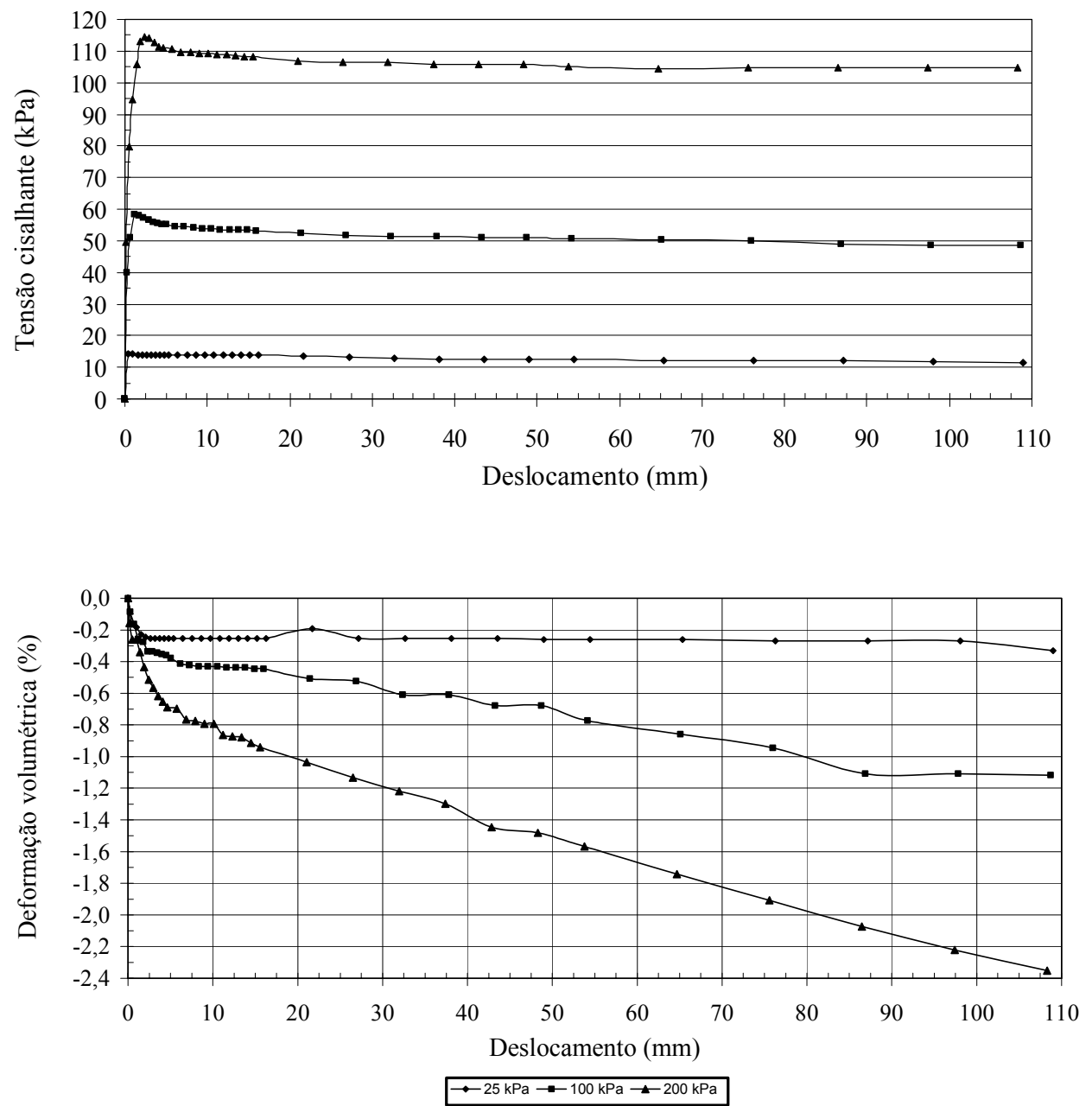

Figura 4.3.1.1. Curvas tensão cisalhante e deformação volumétrica versus deslocamento- interface argila/PVC- solo na umidade ótima, GC=98\%- ensaio não inundado. 


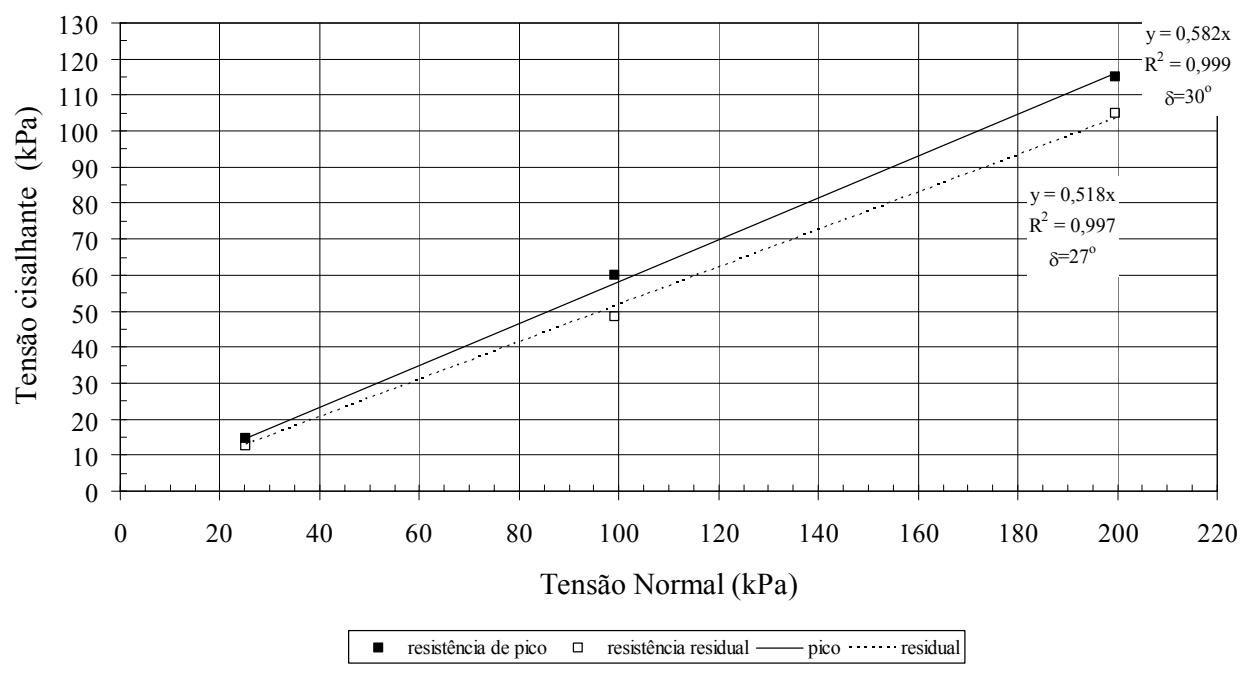

Figura 4.3.1.2. Envoltórias de resistência- PVC/argila- solo na umidade ótima, GC=98\%- ensaio não inundado.

De acordo com estes resultados, constatou-se que a tensão cisalhante de pico em interfaces PVC/argila é mobilizada para deslocamentos entre 1,5 a 3mm. Após atingir a tensão cisalhante de pico, verificou-se um decréscimo de tensão até atingir a condição residual, mobilizada com deslocamentos de aproximadamente $40 \mathrm{~mm}$. Foram observados decréscimos de tensão cisalhante pós-pico de aproximadamente 14\%, 19\% e 10\% para os carregamentos de $25 \mathrm{kPa}, 100 \mathrm{kPa}$ e $200 \mathrm{kPa}$, respectivamente. Quanto ao gráfico de deformação volumétrica, observou-se compressão volumétrica da argila para todos os níveis de carregamentos. Isto é explicado pela extrusão da argila durante toda a fase de cisalhamento, ou seja, perda de material.

Verificou-se que as envoltórias de resistência de pico e residual são aproximadamente lineares paras as interfaces com geomembranas de PVC, alcançando elevados valores de $r^{2}$ e com intercepto de coesão nulo. Foram encontrados para as geomembranas de PVC valores de ângulos de atrito iguais a $30^{\circ}$ (eficiência 0,77 ) e $27 \circ(0,69)$ para a condição de pico e residual. A relação entre as tangentes dos ângulos de atrito residual e de pico, o que quantifica a perda de resistência após a ruptura, é igual a 0,90.

As Figuras 4.3.1.3 e 4.3.1.4 apresentam as curvas de tensão cisalhante e de deformação volumétrica versus deslocamento e as envoltórias de resistência para a interface com geomembranas de PEAD lisa. 

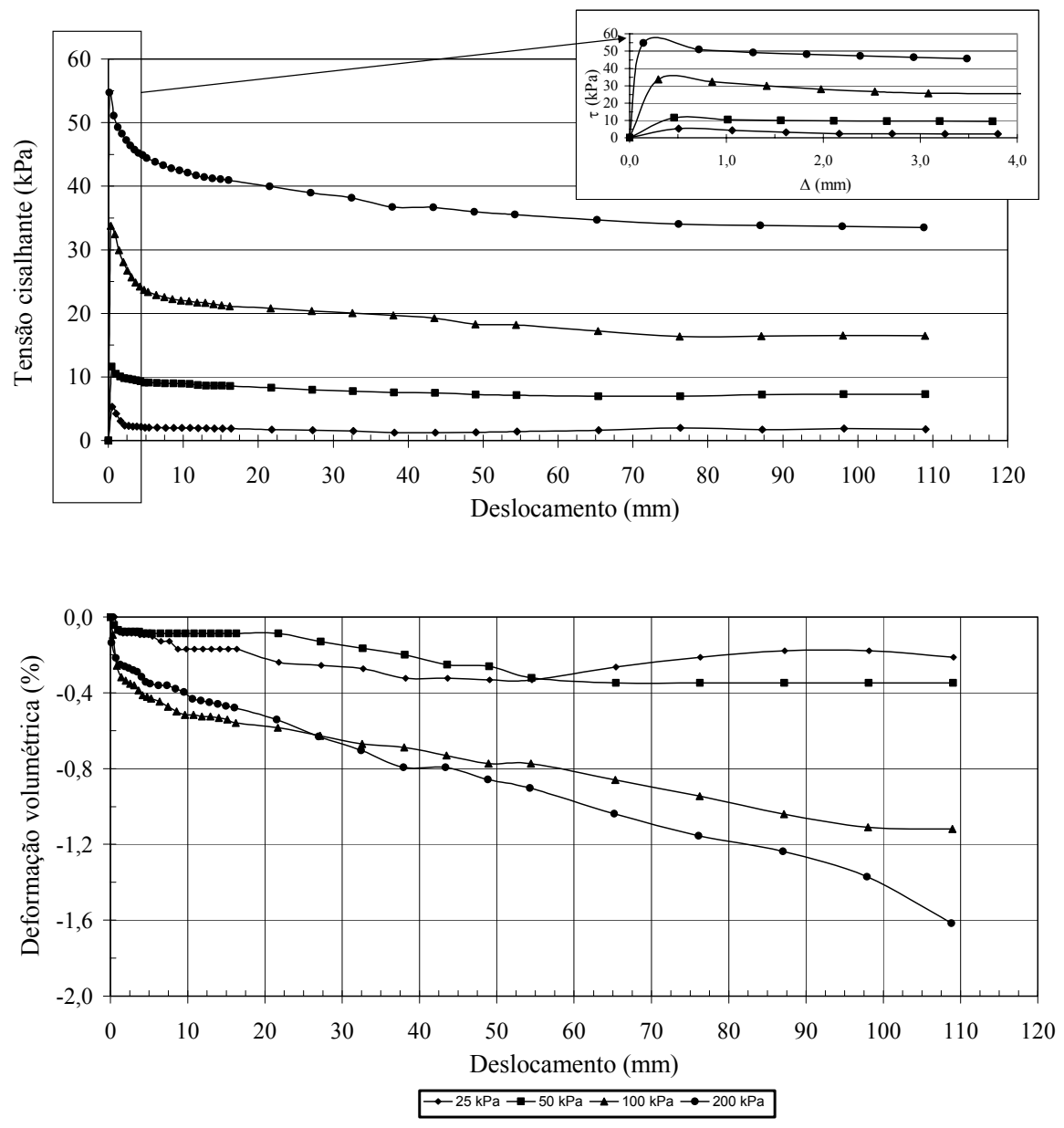

Figura 4.3.1.3. Curvas tensão cisalhante e deformação volumétrica versus deslocamento- interface argila/PEAD- solo na umidade ótima, GC=98\%- ensaio não inundado.

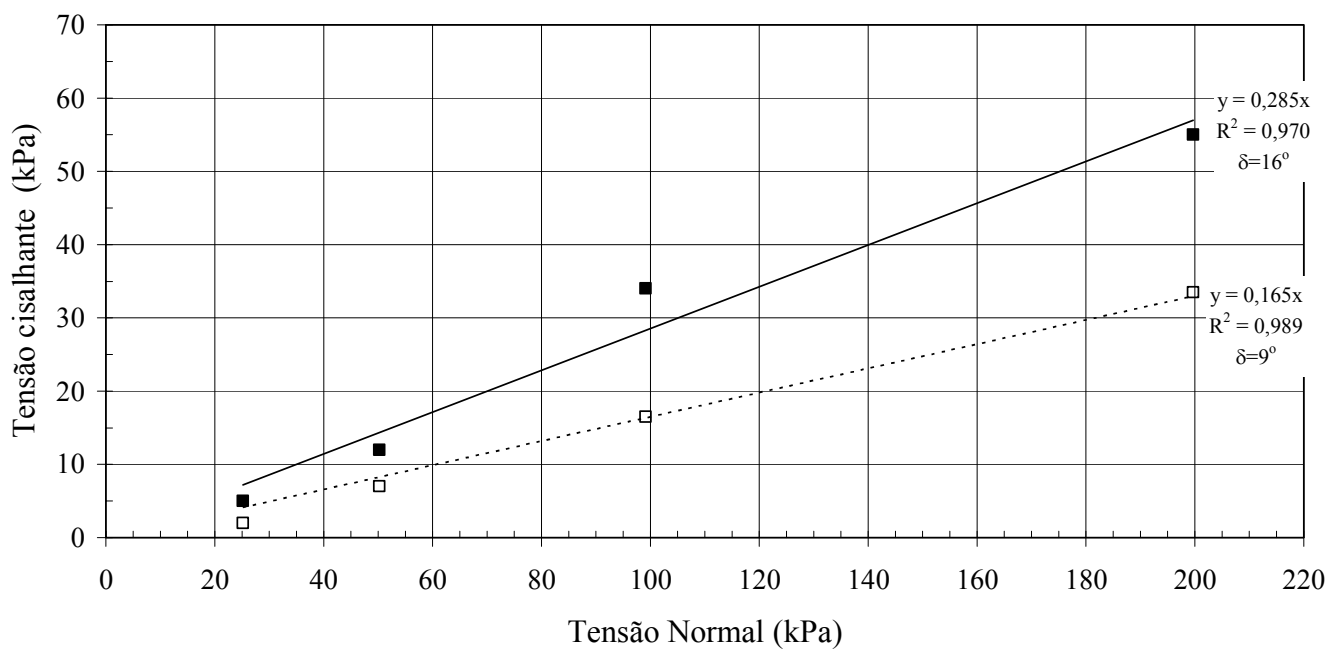

- resistência de pico $\quad \square \quad$ resistência residual $\square$ pico $\cdots$-... residual

Figura 4.3.1.4. Envoltórias de resistência- PEAD/argila- solo na umidade ótima, GC=98\%- ensaio não inundado. 
Nas interfaces com PEAD lisa, a tensão cisalhante de pico foi mobilizada para deslocamentos menores do que observado nas geomembranas de PVC, situando-se entre 0,25 a 0,50mm. Após atingir a condição de pico, houve um decréscimo de tensão cisalhante bastante acentuado até atingir a condição residual, mobilizada para deslocamentos de aproximadamente $80 \mathrm{~mm}$. Observaram-se decréscimos de tensões de 60\%, 42\%, 50\% e 40\% para os carregamentos de $25 \mathrm{kPa}, 50 \mathrm{kPa}, 100 \mathrm{kPa}$ e $200 \mathrm{kPa}$, respectivamente. Comparando-se estes valores com os obtidos nas geomembranas de PVC, verificou-se que a perda de resistência é maior nas geomembranas de PEAD devido à sua rigidez. Também foi verificado que houve compressão volumétrica durante o cisalhamento para todos os carregamentos verticais aplicados.

Os ângulos de atrito de pico e residual obtidos para as geomembranas com PEAD lisa foram $16^{\circ}$ (eficiência de 0,41 ) e $90(0,23)$, respectivamente. A relação obtida entre as tangentes dos ângulos de atrito de pico e residual foi igual a 0,58, o que mostra a elevada perda de resistência pós-pico.

Abaixo, nas Figuras 4.3.1.5 e 4.3.1.6, são apresentadas as curvas de tensão cisalhante e de deformação volumétrica versus deslocamento, e as envoltórias de resistência das interfaces com geomembranas de PE linear.

Constatou-se que a tensão cisalhante de pico é mobilizada para deslocamentos entre 0,3 a $0,5 \mathrm{~mm}$. Também foi verificado decréscimo de tensão cisalhante pós-pico para todos os carregamentos, atingindo a condição residual por volta de $80 \mathrm{~mm}$ de deslocamentos. Os decréscimos observados foram 38\%, $46 \%$ e $38 \%$ referentes aos carregamentos de $25 \mathrm{kPa}$, $100 \mathrm{kPa}$ e 200kPa. Nas geomembranas de PELMD foram obtidos ângulos de atrito de pico e residual iguais a $17^{\circ}(0,44)$ e $10^{\circ}(0,26)$, respectivamente. A relação entre as tangentes dos ângulos de atrito residual e de pico é igual a 0,60 .

Comparando-se as curvas 4.3.1.1, 4.3.1.3 e 4.3.1.5, pôde-se concluir que a interface com geomembrana de PEAD apresentou maior queda de tensão cisalhante pós-pico do que observado na interface com geomembranas de PVC. Apesar de se verificar o mesmo nas geomembranas de PE linear, este efeito foi ligeiramente menos pronunciado em função de seus aspectos intermediários de rigidez. 

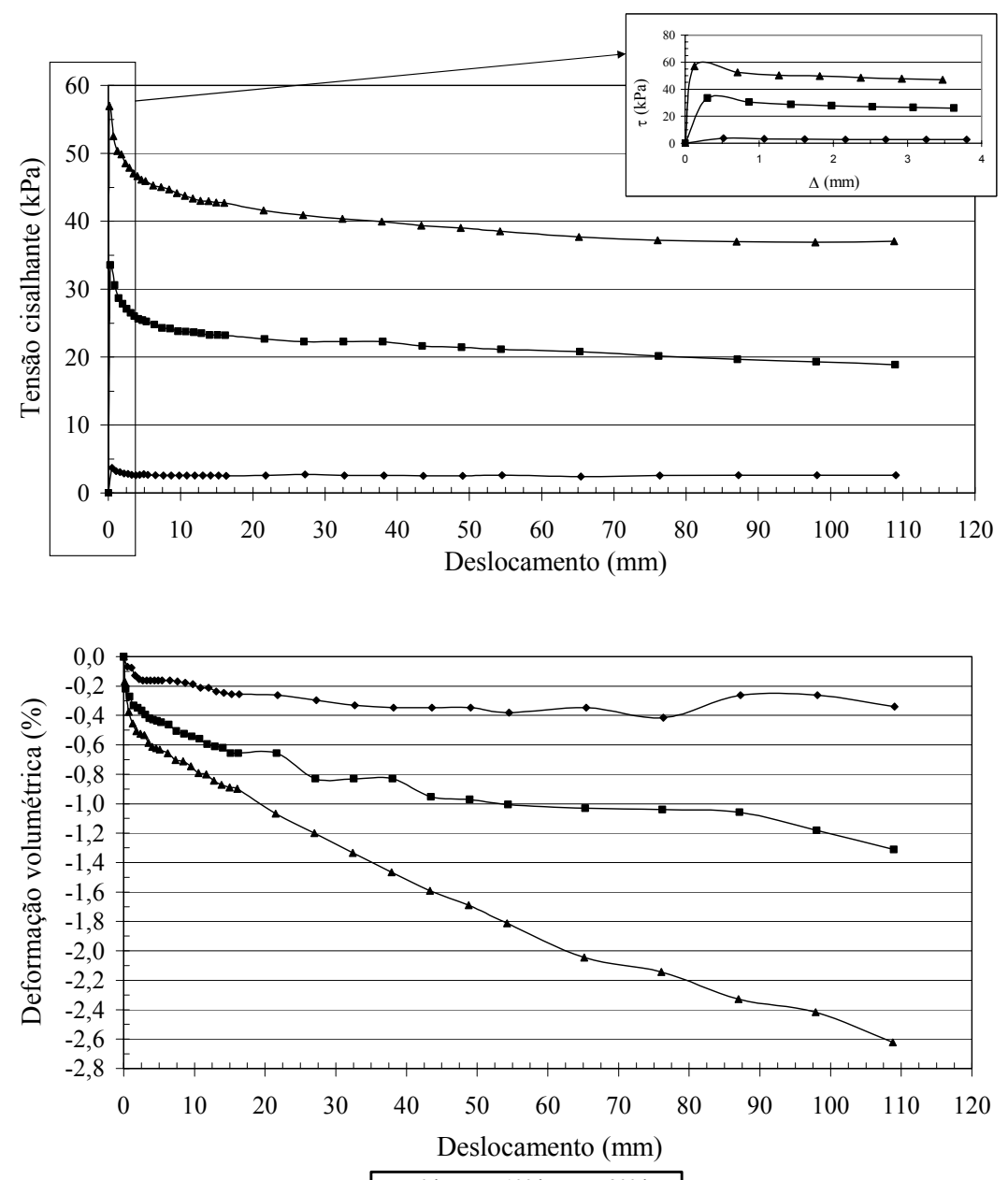

$\rightarrow-50 \mathrm{kPa} \rightarrow-100 \mathrm{kPa} \leftarrow-200 \mathrm{kPa}$

Figura 4.3.1.5. Curvas tensão cisalhante e deformação volumétrica versus deslocamento- interface argila/PE linear- solo na umidade ótima, GC=98\%- ensaio não inundado.

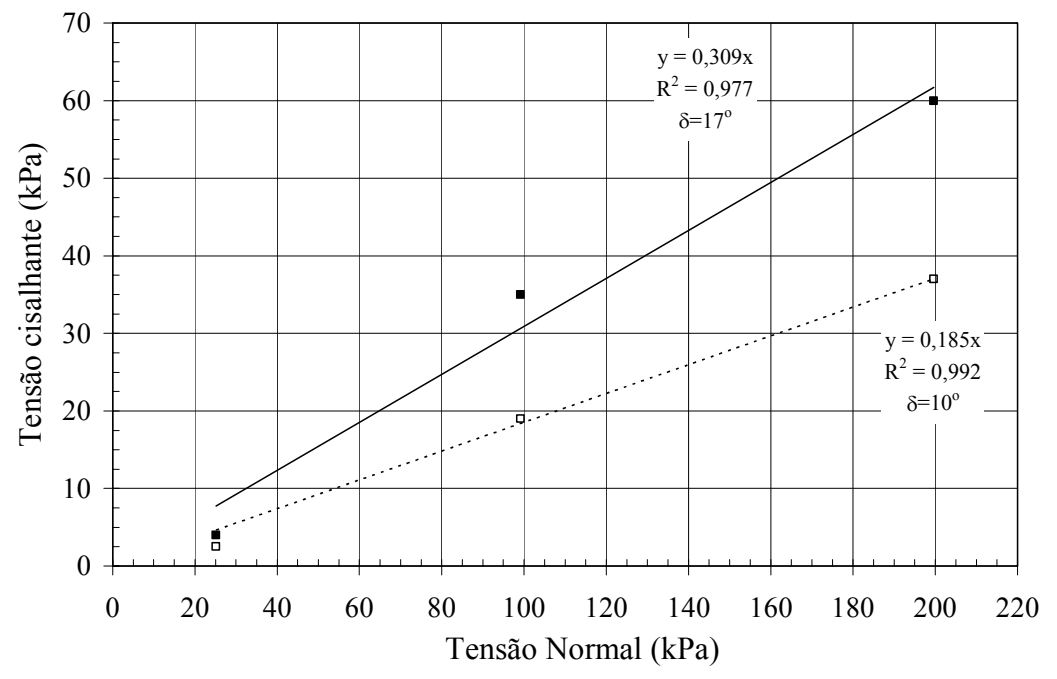

- resistência de pico $\quad \square \quad$ resistência residual $\square$ pico $\cdots$ residual

Figura 4.3.1.6. Envoltórias de resistência- PELMD/argila- solo na umidade ótima, GC=98\%- ensaio não inundado. 
Nas Figuras 4.3.1.7 e 4.3.1.8 são apresentados os resultados dos ensaios de interface com geomembrana de PEAD texturizada do tipo AR.
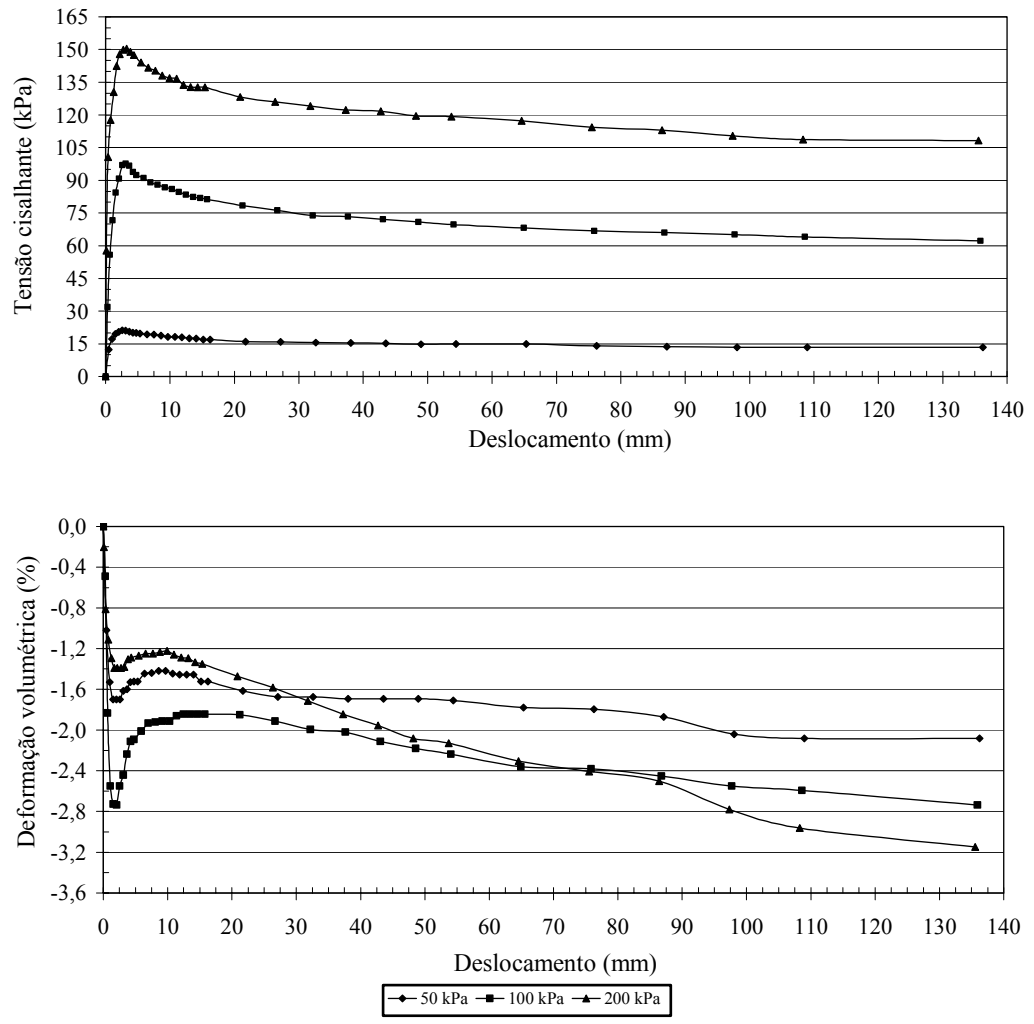

Figura 4.3.1.7. Curvas tensão cisalhante e deformação volumétrica versus deslocamento- interface argila/PEAD AR- solo na umidade ótima, GC=98\%- ensaio não inundado.

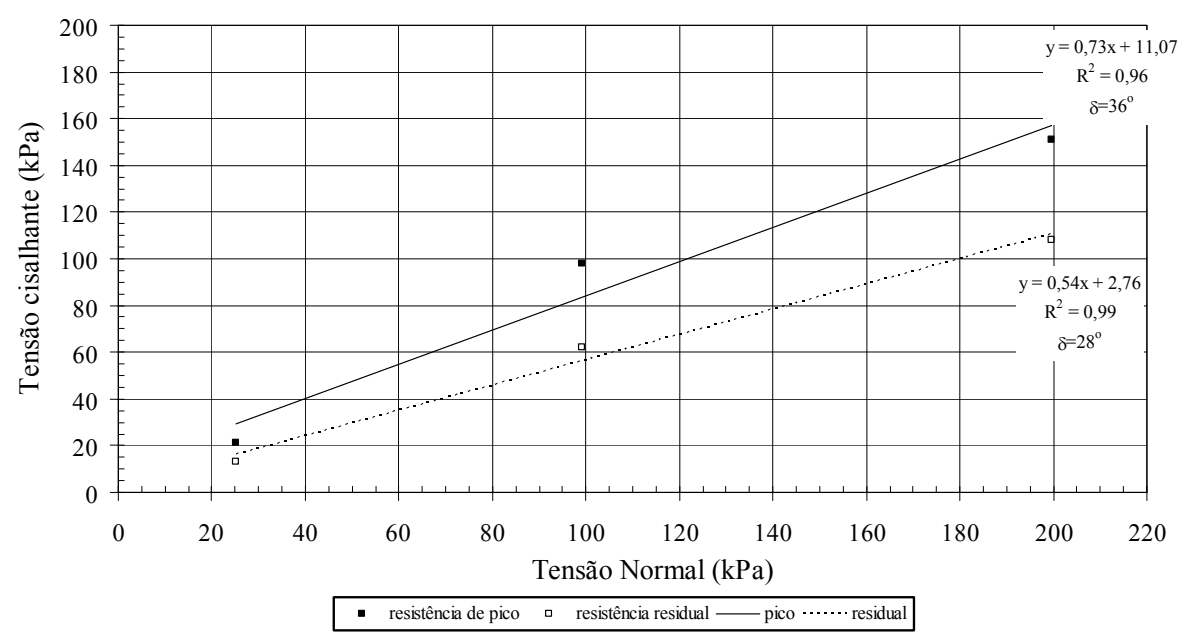

Figura 4.3.1.8. Envoltórias de resistência- PEAD AR/argila- solo na umidade ótima, GC=98\%- ensaio não inundado. 
Em função da rugosidade das geomembranas, a tensão cisalhante de pico em interfaces com PEAD AR foi mobilizada com deslocamentos maiores do que observado nas geomembranas de PEAD lisa, variando de $2,5 \mathrm{~mm}$ a 5,0 mm. Verificou-se também um menor decréscimo de tensão pós-pico, atingindo a condição residual por volta de $100 \mathrm{~mm}$. Estes deslocamentos foram maiores do que os deslocamentos obtidos nas geomembranas lisas, sendo também atribuídos à textura da geomembrana. Os decréscimos de resistência verificados foram de $39 \%, 36 \%$ e $28 \%$ para os carregamentos de $25 \mathrm{kPa}, 100 \mathrm{kPa}$ e $200 \mathrm{kPa}$, respectivamente.

Verificou-se que as envoltórias de resistência também são aproximadamente lineares para as geomembranas de PEAD AR com intercepto de coesão de aproximadamente $11 \mathrm{kPa}$, para a condição de pico, e de 3kPa, para a condição residual. Foram obtidos valores de ângulo de atrito de pico igual a $36^{\circ}$ (eficiência 0,92), e residual igual a $28^{\circ}(0,72)$. Observou-se que a relação entre as tangentes dos ângulos de atrito residual e de pico é igual a 0,74.

A Figura 4.3.1.9 apresenta as envoltórias de resistência de pico e residual para as interfaces com geomembranas texturizadas de PEAD AR e de PEAD lisa, com o intuito de verificar o efeito da textura das membranas sobre a resistência de interface envolvendo materiais argilosos.

Com base nesta figura, verificou-se que a perda de atrito pós-pico para geomembranas texturizadas do tipo AR é menor comparada as geomembranas de PEAD lisa, em função da rugosidade de sua superfície.

Constatou-se também que as geomembranas texturizadas de PEAD AR apresentaram um aumento no ângulo de atrito de pico equivalente a $125 \%$, e no ângulo residual igual a $211 \%$ comparado as geomembranas de PEAD lisa. 


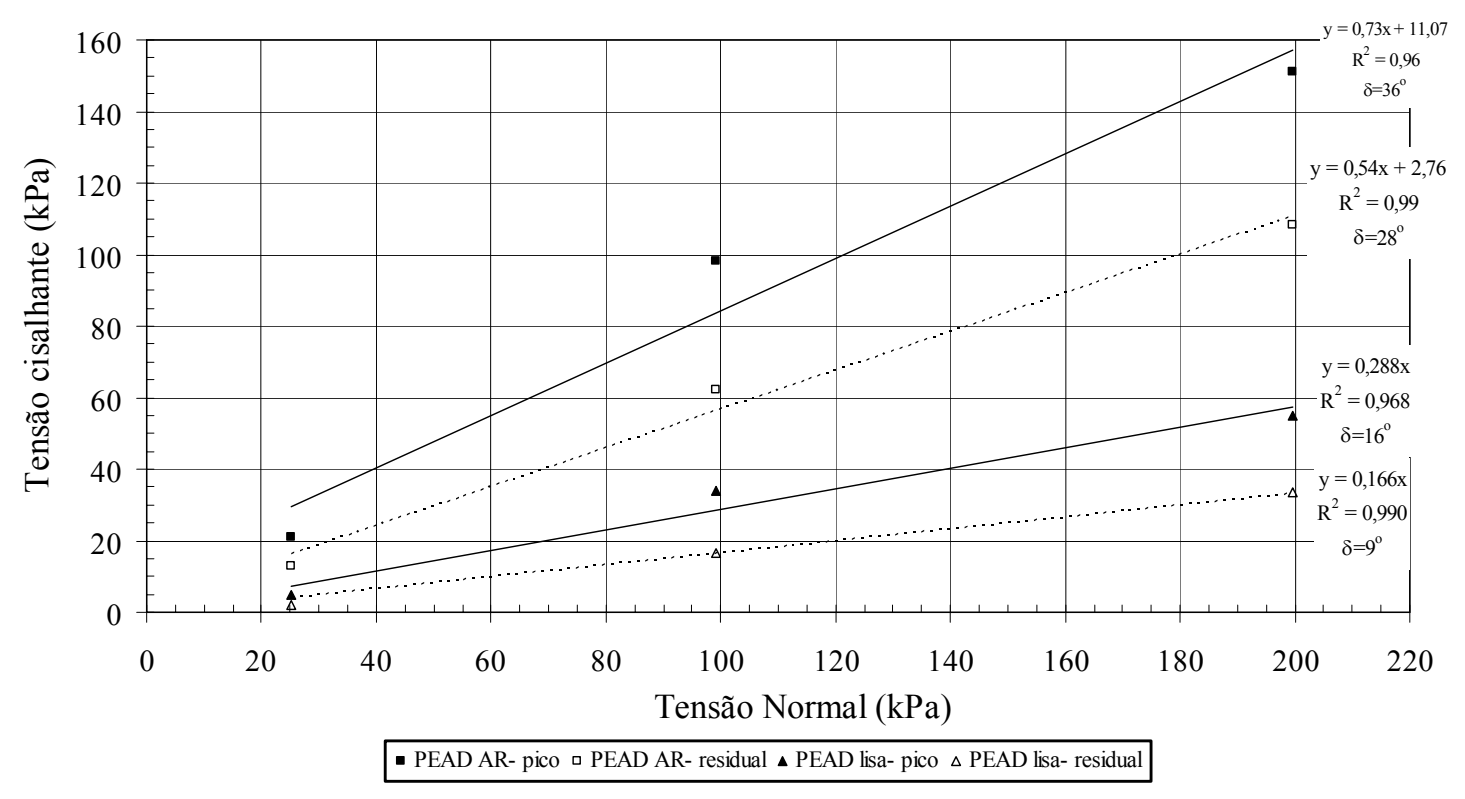

Figura 4.3.1.9. Verificação da influência da textura- PEAD AR/PEAD lisa.

Nas Figuras 4.3.1.10 e 4.3.1.11 são apresentadas fotos da superfície do solo após cisalhamento com geomembranas de PEAD lisa e PEAD AR, respectivamente.

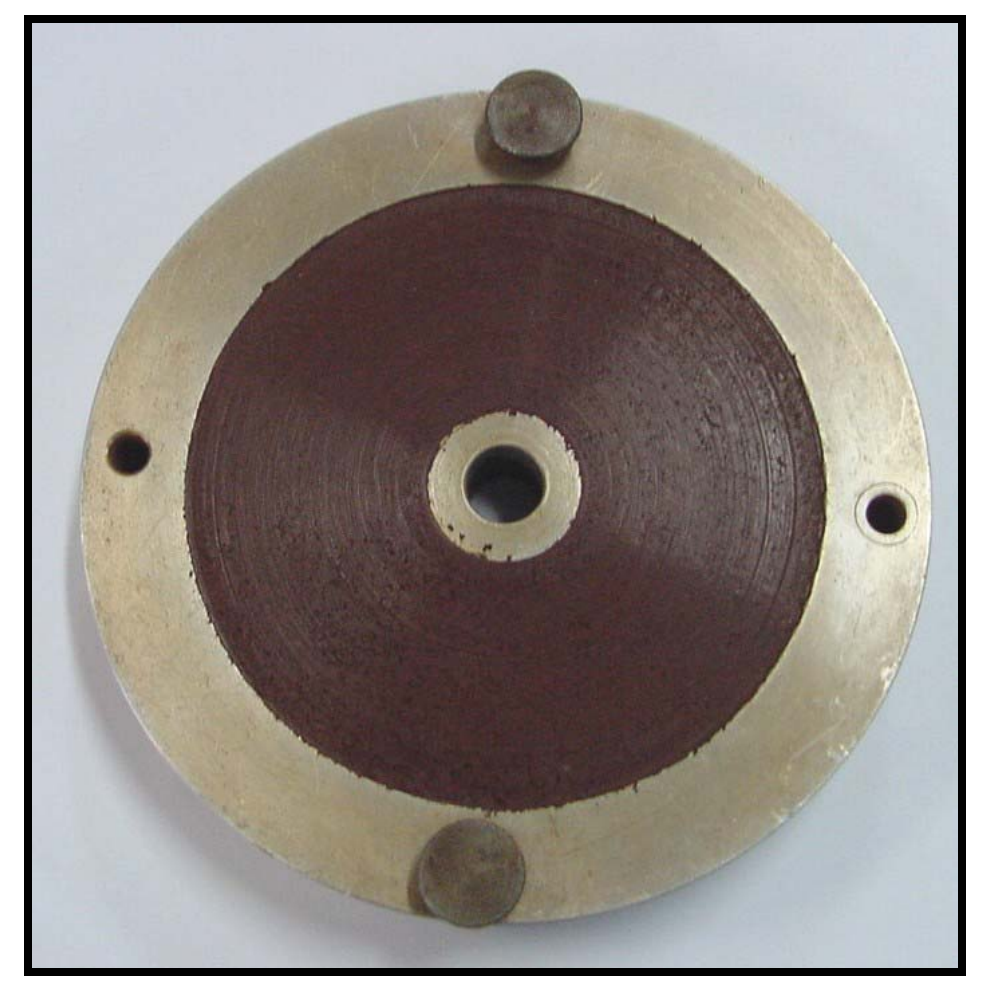

Figura 4.3.1.10. Foto da superfície do solo após cisalhamento com geomembrana de PEAD lisa. 


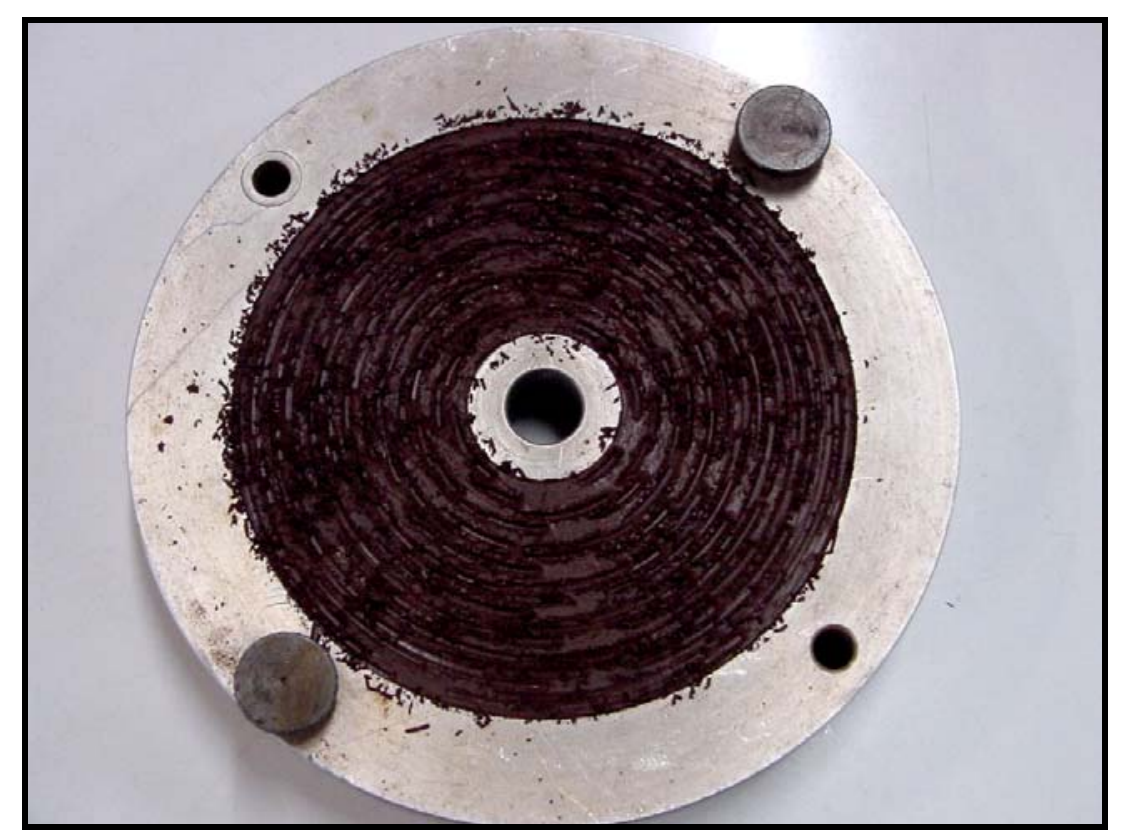

Figura 4.3.1.11. Foto da superfície do solo após cisalhamento com geomembrana de PEAD AR.

Nota-se que a superfície do solo na interface com geomembrana de PEAD lisa permanece praticamente inalterada, com pequenos estriamentos. Ao contrário, a amostra cisalhada com geomembrana de PEAD AR apresenta sulcos em sua superfície atribuídos ao entrosamento da geomembrana e o solo, o que justifica o elevado atrito encontrado em interfaces com geomembranas de PEAD AR.

\subsubsection{Efeito da inundação na resistência de interface}

Com o intuito de analisar o efeito que a umidade exerce no comportamento de resistência de interfaces e, adotando como referencial os ensaios não inundados, foram realizados alguns ensaios com inundação do corpo prova. Para tal, o efeito da inundação foi verificado nas interfaces com material moldado com GC igual a $98 \%\left(\gamma_{d}=15,6 \mathrm{kN} / \mathrm{m}^{3}\right)$ e na umidade ótima $(w=26,7 \%)$. 


\section{a) Interfaces com geomembranas de PVC.}

A Figura 4.3.2.1 mostra a curva de tensão cisalhante e de deformação volumétrica versus deslocamento referente à interface PVC/argila. Na Figura 4.3.2.2 são apresentadas as envoltórias de resistência na condição não inundada e inundada, também referentes a esta interface.
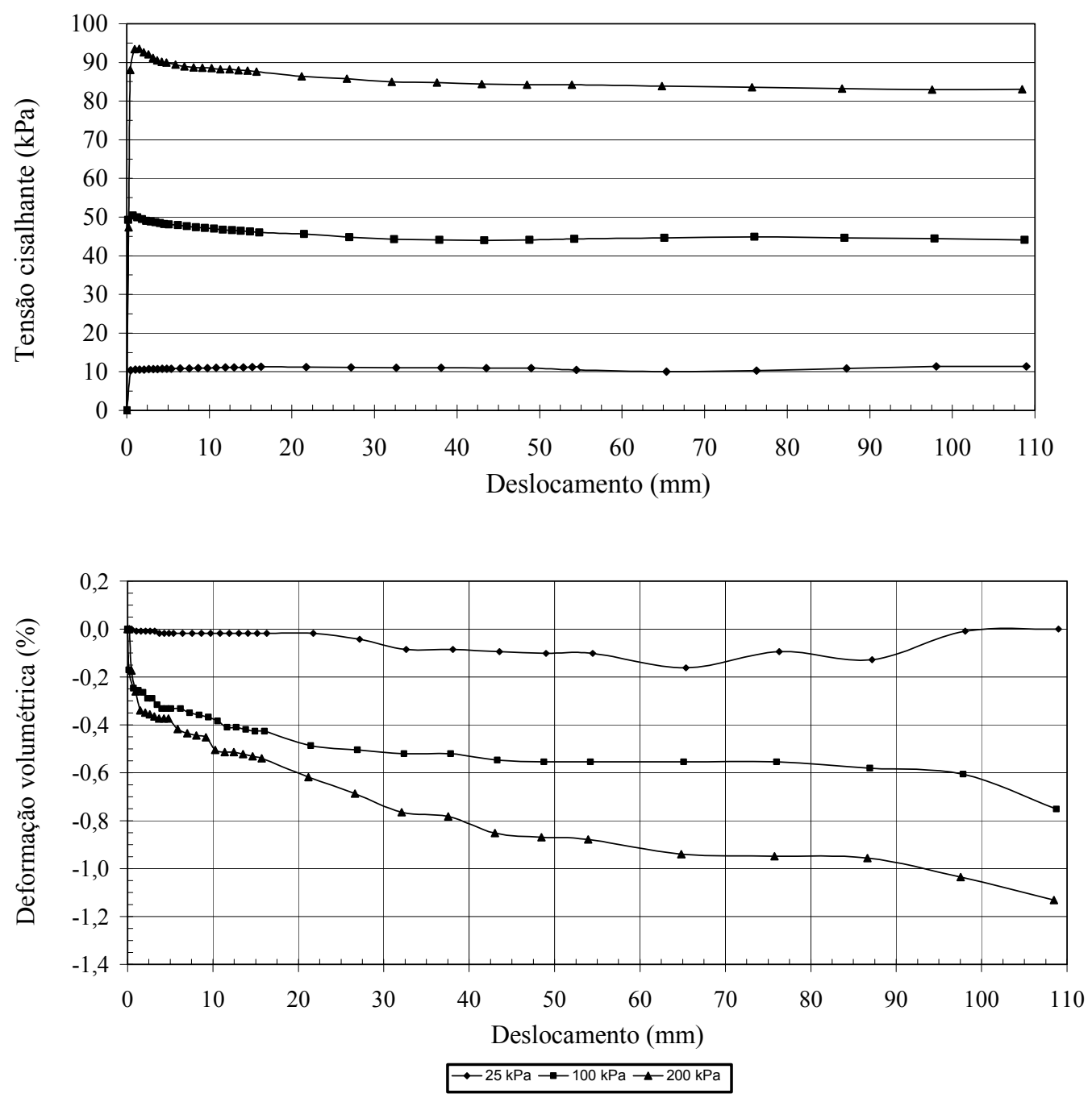

Figura 4.3.2.1. Curvas tensão cisalhante e deformação volumétrica versus deslocamento- PVC/argila- solo na umidade ótima, GC=98\%/ ensaio inundado. 


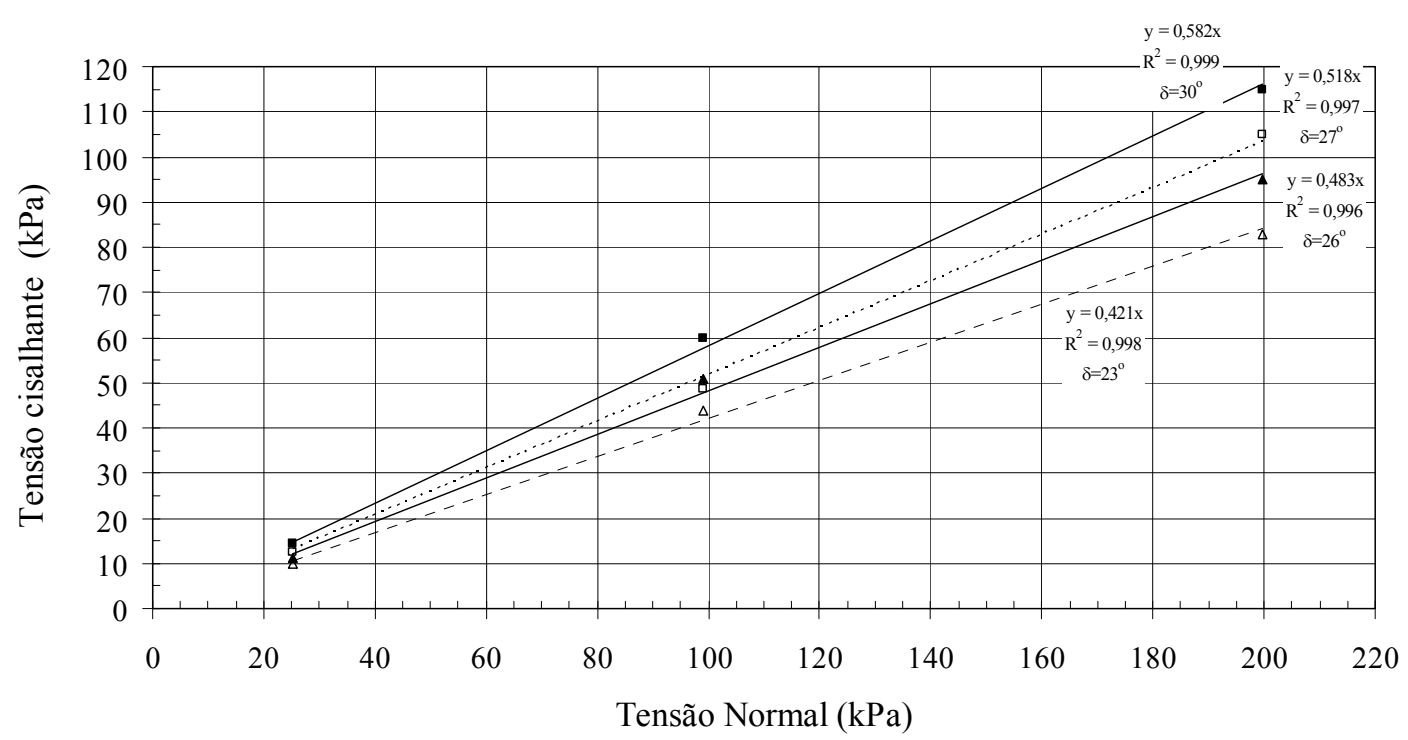

- ensaio não inundado- pico ${ }^{\circ}$ ensaio não inundado- residual $\bullet$ ensaio inundado-pico $\Delta$ ensaio inundado- residual

Figura 4.3.2.2. Comparação entre condição não inundada e inundada- solo na umidade ótima, GC=98\%.

Analisando-se a Figura 4.3.2.1 e comparando-a com os resultados realizados em condição não inundada (Figura 4.3.1.1), verificou-se que a tensão cisalhante de pico na condição inundada é mobilizada com deslocamentos entre 1 e $2 \mathrm{~mm}$. Estes deslocamentos foram menores do que os obtidos na condição não inundada. Por sua vez, a condição residual foi mobilizada com os mesmos deslocamentos em ambas as condições $(50 \mathrm{~mm})$. Observou-se ainda que a tensão cisalhante de pico e residual na condição inundada é menor que na condição não inundada. Como exceção, tem-se apenas o carregamento de $25 \mathrm{kPa}$, no qual as tensões residuais são semelhantes em ambas às condições.

Constatou-se um decréscimo de aproximadamente $14 \%$ no ângulo de atrito de pico e $15 \%$ no ângulo de atrito residual atribuído à inundação do corpo de prova.

\section{b) Interfaces com geomembranas de PEAD lisa.}

Na Figura 4.3.2.3 são apresentadas as curvas de tensão cisalhante e de deformação volumétrica versus deslocamento da interface argila/PEAD 
dos ensaios inundados e compactados na umidade ótima. Na Figura 4.3.2.4 são apresentadas as envoltórias de resistência na condição não inundada e inundada para a mesma umidade de compactação.
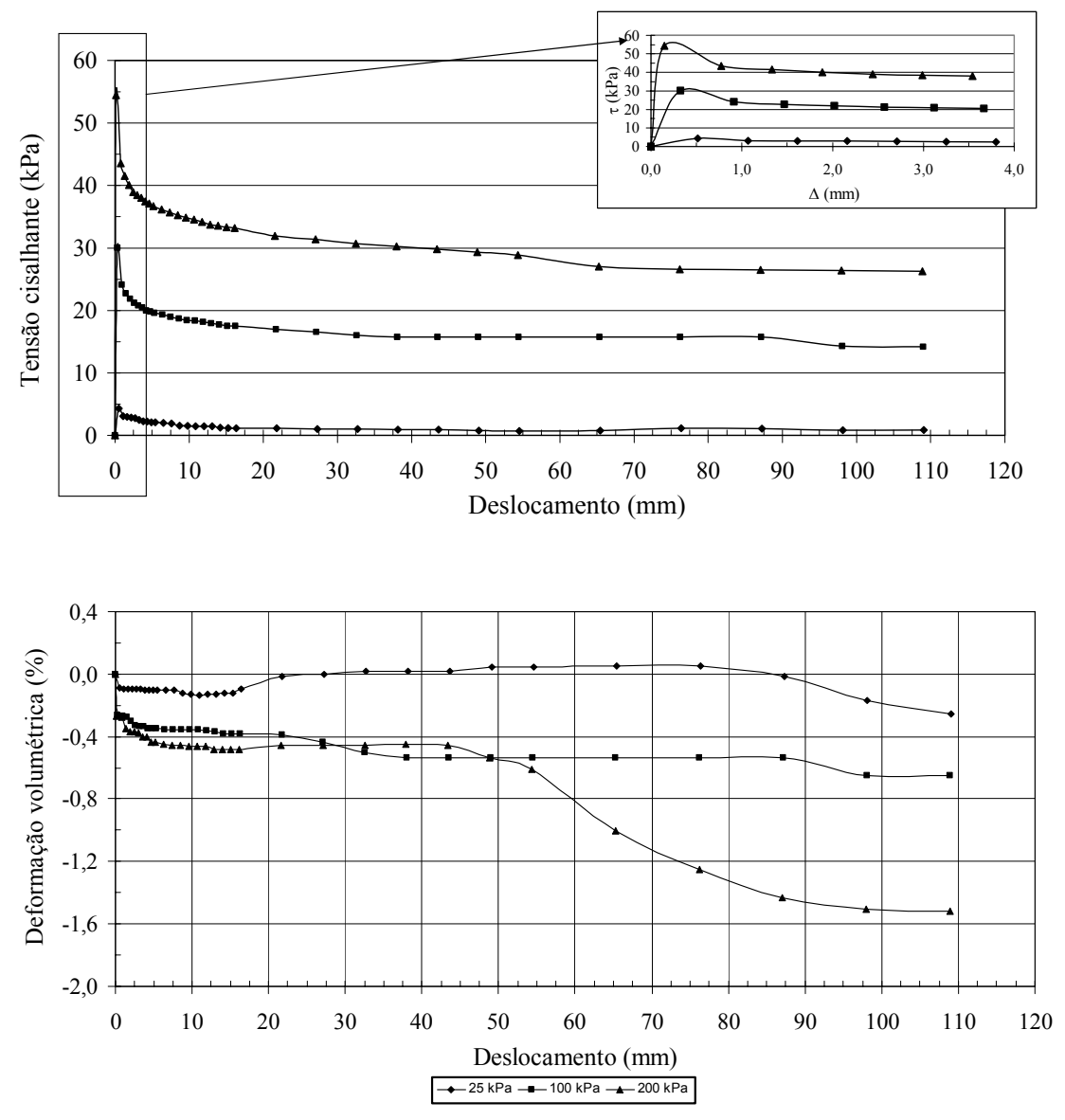

Figura 4.3.2.3. Curvas tensão cisalhante e deformação volumétrica versus deslocamento- PEAD/argila- solo na umidade ótima, GC=98\%/ ensaio inundado.

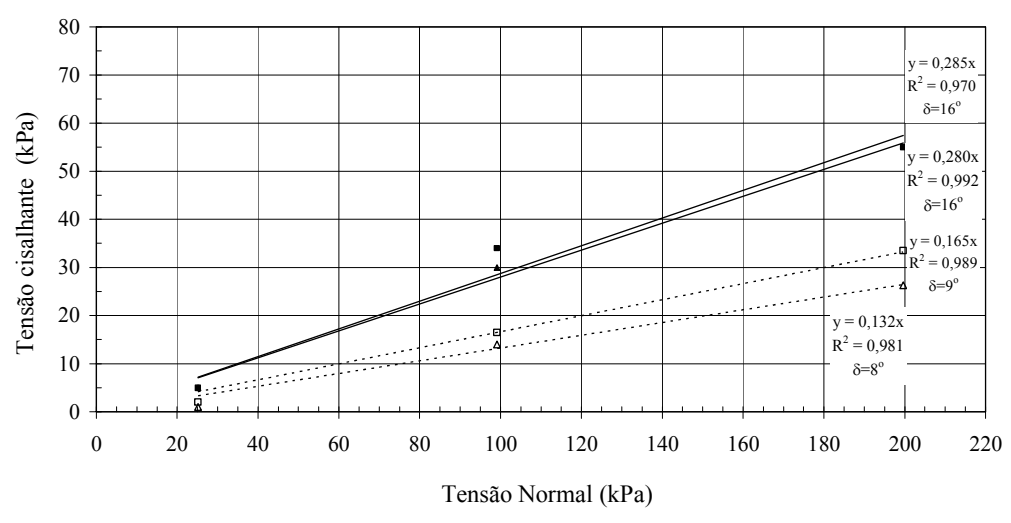

- ensaio não inundado- pico $\square$ ensaio não inundado- residual $\triangleleft$ ensaio inundado- pico $\Delta$ ensaio inundado- residual

Figura 4.3.2.4. Comparação entre condição não inundada e inundada- solo na umidade ótima, GC=98\%. 
Analisando-se os resultados acima, verificou-se que a tensão cisalhante de pico é mobilizada com deslocamentos variando de 0,2 a 0,5mm nos ensaios inundados e não inundados. A tensão residual, por sua vez, somente foi alcançada a partir dos 60 a $70 \mathrm{~mm}$ no ensaio inundado; enquanto no ensaio não inundado a tensão residual foi mobilizada com $80 \mathrm{~mm}$ de deslocamentos. Nesta interface, diferentemente do verificado nas membranas de PVC, a tensão cisalhante de pico na condição inundada foi aproximadamente igual à condição não inundada.

Quanto à perda de tensão cisalhante, observaram-se decréscimos nos ensaios inundados de $80 \%, 53 \%$ e $52 \%$ para os carregamentos de $25 \mathrm{kPa}$, $100 \mathrm{kPa}$ e $200 \mathrm{kPa}$, respectivamente. As perdas de tensão cisalhante observadas foram maiores do que as obtidas nos ensaios não inundados. Foram obtidos ângulos de atrito de pico igual a $16^{\circ}(0,50)$ e, residual igual a $8^{\circ}$ $(0,25)$ nos ensaios inundados. Nos ensaios não inundados foram obtidos valores de ângulos de atrito de pico e residuais iguais a $16^{\circ}(0,41)$ e $9^{\circ}(0,23)$, respectivamente. Para a condição de pico, foram obtidos os mesmos ângulos de atrito em ambas as condições; enquanto na condição residual a variação foi pequena, podendo ser considerada desprezível.

\section{c) Interfaces com geomembranas de PEAD AR.}

Nas Figuras 4.3.2.5 e 4.3.2.6 são apresentadas as curvas de tensão cisalhante versus deslocamento e as envoltórias de resistência da interface argilla/PEAD AR, ambas relativas aos ensaios inundados e compactados na umidade ótima.

Observa-se que a tensão cisalhante de pico nos ensaios inundados foi mobilizada com deslocamentos entre $2,5 \mathrm{~mm}$ e $5,0 \mathrm{~mm}$. A mesma magnitude de deslocamentos foi observada para a condição de pico nos ensaios não inundados. Quanto à tensão residual, foi mobilizada a partir dos $80 \mathrm{~mm}$ nos ensaios inundados e, 100mm nos ensaios não inundados. Os ângulos de atrito obtidos para a condição de pico e residual nos ensaios inundados foram $32^{\circ}$ $(1,00)$ e $26^{\circ}(0,81)$, respectivamente. Por outro lado, nos ensaios não inundados foram obtidos ângulos de $36^{\circ}(0,92)$, para a condição de pico, e $28^{\circ}(0,72)$, 
para a condição residual. Nota-se que a inundação do corpo de prova promoveu uma redução no ângulo de atrito de pico em $11 \%$, e no ângulo de atrito residual em $7 \%$.
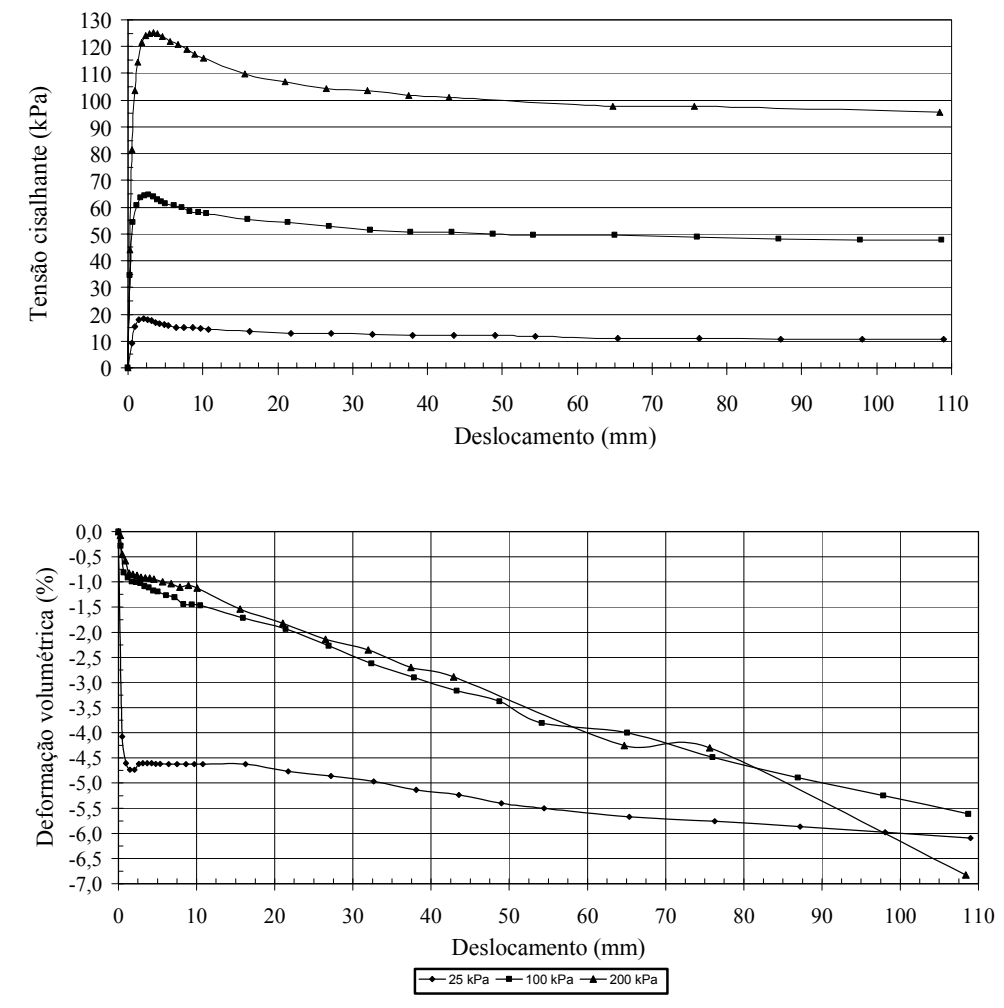

Figura 4.3.2.5. Curvas tensão cisalhante e deformação volumétrica versus deslocamento- PEAD AR/argila- solo na umidade ótima, GC=98\% / ensaio inundado.

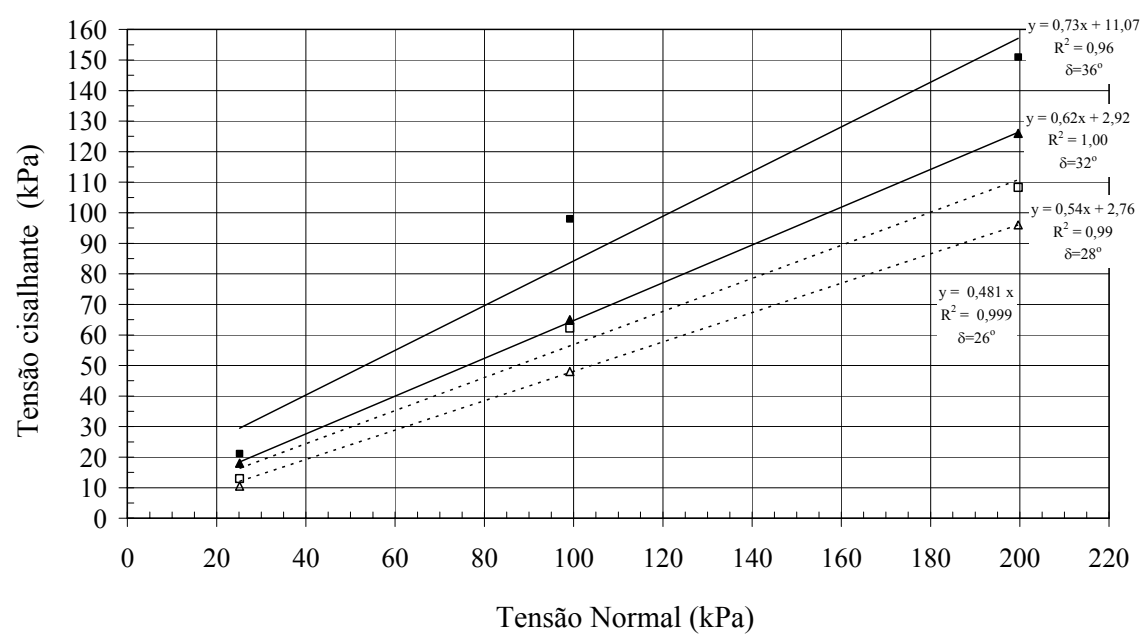

- ensaio não inundado- pico $\square$ ensaio não inundado- residual $\Delta$ ensaio inundado- pico $\Delta$ ensaio inundado- residual

Figura 4.3.2.6. Comparação entre condição não inundada e inundada- solo na umidade ótima, GC=98\%. 
Na Tabela 4.3.2.1 é apresentado um sumário dos resultados dos ensaios realizados em condição inundada e não inundada, com material argiloso moldado com GC igual a $98 \%$.

Tabela 4.3.2.1. Sumários dos ensaios de interface- Material moldado com GC=98\%.

\begin{tabular}{|c|c|c|c|c|c|c|c|c|}
\hline \multirow{3}{*}{ Interface } & \multicolumn{8}{|c|}{ Condição do Ensaio } \\
\hline & \multicolumn{4}{|c|}{ Inundado } & \multicolumn{4}{|c|}{ Não Inundado } \\
\hline & $\begin{array}{c}C_{p} \\
(k P a)\end{array}$ & $\delta p$ & $\begin{array}{c}\mathrm{C}_{r} \\
(\mathrm{kPa})\end{array}$ & $\delta r$ & $\begin{array}{c}\mathrm{C}_{\mathrm{p}} \\
(\mathrm{kPa})\end{array}$ & $\delta p$ & $\begin{array}{c}c_{r} \\
(k P a)\end{array}$ & $\delta r$ \\
\hline PVC & - & $\begin{array}{c}26^{\circ} \\
(0,81)\end{array}$ & - & $\begin{array}{c}23^{\circ} \\
(0,72)\end{array}$ & - & $\begin{array}{c}30^{\circ} \\
(0,77)\end{array}$ & - & $\begin{array}{c}27^{\circ} \\
(0,69)\end{array}$ \\
\hline PEAD lisa & - & $\begin{array}{c}16^{\circ} \\
(0,50)\end{array}$ & - & $\begin{array}{c}8^{\circ} \\
(0,25)\end{array}$ & - & $\begin{array}{c}16^{\circ} \\
(0,41)\end{array}$ & - & $\begin{array}{c}9^{\circ} \\
(0,23)\end{array}$ \\
\hline PELMD & - & - & - & - & - & $\begin{array}{c}17^{\circ} \\
(0,44)\end{array}$ & - & $\begin{array}{c}10^{\circ} \\
(0,26)\end{array}$ \\
\hline PEAD AR & 3 & $\begin{array}{c}32^{\circ} \\
(1,00)\end{array}$ & - & $\begin{array}{c}26^{\circ} \\
(0,81)\end{array}$ & 11 & $\begin{array}{c}36^{\circ} \\
(0,92)\end{array}$ & 3 & $\begin{array}{c}28^{\circ} \\
(0,72)\end{array}$ \\
\hline
\end{tabular}

\subsubsection{Influência do grau de compactação na resistência de interface}

Com o intuito de verificar a influência do grau de compactação na resistência de interface, foram realizadas algumas comparações dos resultados dos ensaios de interface realizados com GC igual a 98\% (terceiro estágio do programa) e GC igual a 85\% (quarto estágio). Em todos os resultados apresentados, o material argiloso foi moldado na umidade ótima (Wótima $=26,7 \%$ ).

\section{a) Efeito do peso específico em ensaios inundados}

Nas Figuras 4.3.3.1 e 4.3.3.2 são apresentadas as curvas de tensão cisalhante e de deformação volumétrica versus deslocamento, e as 
envoltórias de resistência dos ensaios de interface PVC/argila, respectivamente, referentes ao grau de compactação de $85 \%$.
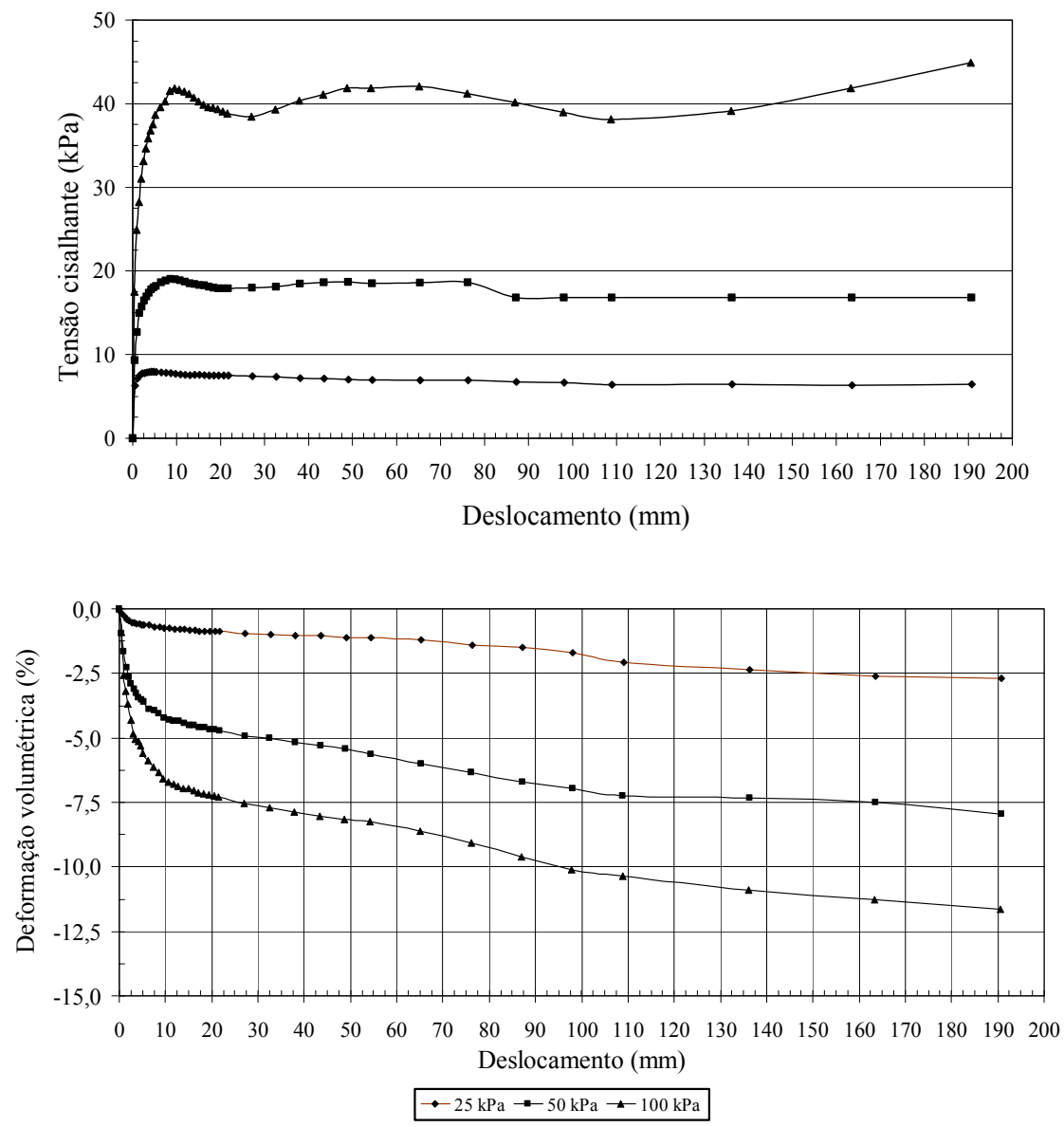

Figura 4.3.3.1. Curvas tensão cisalhante e deformação volumétrica versus deslocamento- PVC/argila- solo na umidade ótima e GC=85\%/ ensaio inundado.

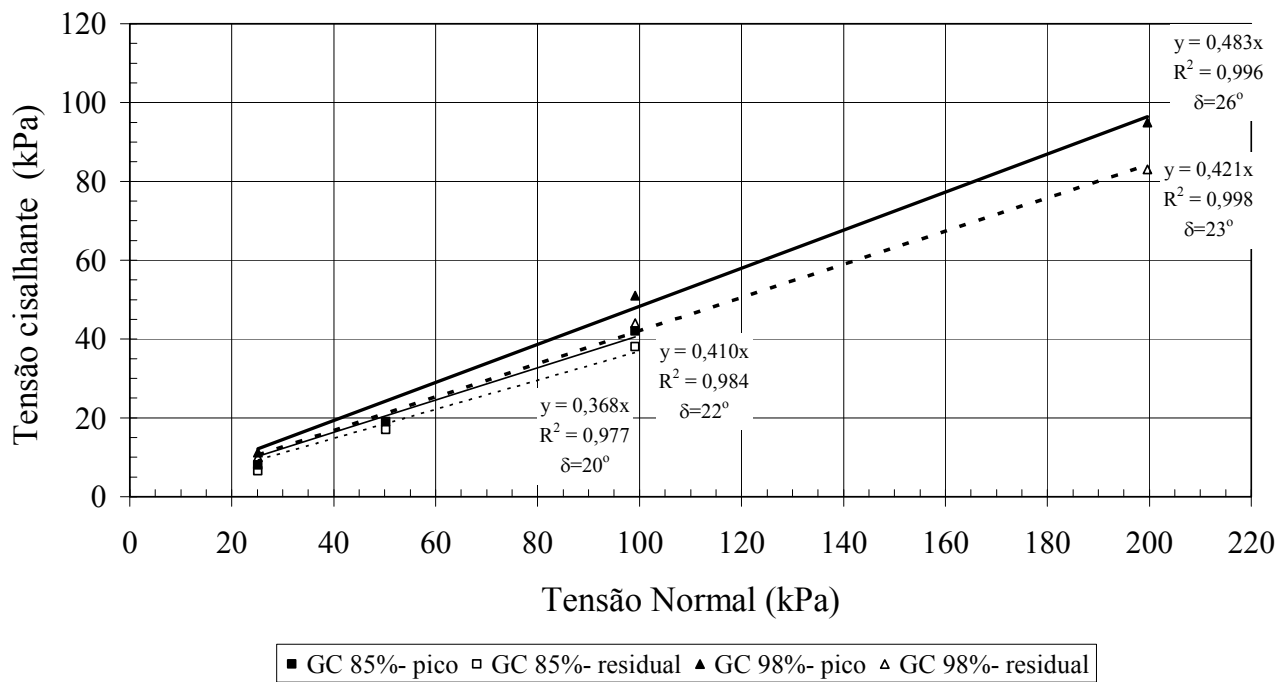

Figura 4.3.3.2. Verificação do grau de compactação- interface PVC/argilasolo na umidade ótima, ensaio inundado. 
Analisando-se estes resultados, observa-se que no ensaio inundado com GC igual a 85\%, a tensão cisalhante de pico foi mobilizada com deslocamentos entre 4 e $8 \mathrm{~mm}$, deslocamentos estes maiores do que observados nas interfaces com GC igual a 98\% (Figura 4.3.2.1). Após atingir a condição de pico, observou-se uma oscilação no comportamento de resistência, atingindo a condição residual por volta dos $110 \mathrm{~mm}$ de deslocamentos. Na interface com GC igual a 98\%, verificou-se que após a tensão cisalhante atingir o valor de pico, ocorre uma estabilização da resistência, que por sua vez, atinge a condição residual em torno de 60 à $70 \mathrm{~mm}$.

Para a interface com solo moldado com GC igual a 85\%, foram obtidos valores de ângulo de atrito iguais a $22^{\circ}$ (pico) e $20^{\circ}$ (residual). Observase que os valores de atrito obtidos nos ensaios inundados com GC igual a $85 \%$ foram menores do que os obtidos nos ensaios inundados com GC igual a $98 \%$. Nestes últimos foram obtidos ângulos de atrito de pico e residual iguais a $26^{\circ} \mathrm{e}$ 23․, respectivamente. Desta forma, pôde-se constatar que o grau de compactação do solo interfere nas propriedades de atrito em ensaios inundados, porém não tanto como se esperaria considerando-se as diferenças de compacidade das duas amostras.

Nas Figuras 4.3.3.3 e 4.3.3.4 são apresentados os resultados dos ensaios de interface PEAD lisa/argila, realizados em condição inundada e com grau de compactação igual a $85 \%$.

Analisando-se estas figuras, pôde-se observar que a tensão cisalhante de pico é mobilizada com deslocamentos entre 0,5 a $1,5 \mathrm{~mm}$ nos ensaios com GC igual a 85\%. Nos ensaios com GC igual a 98\% (Figura 4.3.2.3), observou-se menores deslocamentos para atingir a condição de pico $(0,2$ a 0,5mm). A condição residual em ambos os graus de compactação foi alcançada com os mesmos deslocamentos. Desta forma, averiguou-se que o comportamento da curva tensão cisalhante versus deslocamento é semelhante em ambas as interfaces, observando-se um valor de tensão cisalhante máximo seguido de uma perda pós-pico até atingir um valor residual.

Contudo, foram obtidos valores de ângulos de atrito iguais a $14^{\circ} \mathrm{e} 7^{\circ}$, referentes às condições de pico e residual, nas interfaces com GC igual a $85 \%$. Nas interfaces com GC igual a 98\%, foram obtidos valores aproximadamente 
iguais a $16^{\circ}$ e $8^{\circ}$. Ou seja, observou-se nos ensaios inundados uma pequena diminuição nos ângulos de atrito com a diminuição do grau de compacidade da argila.
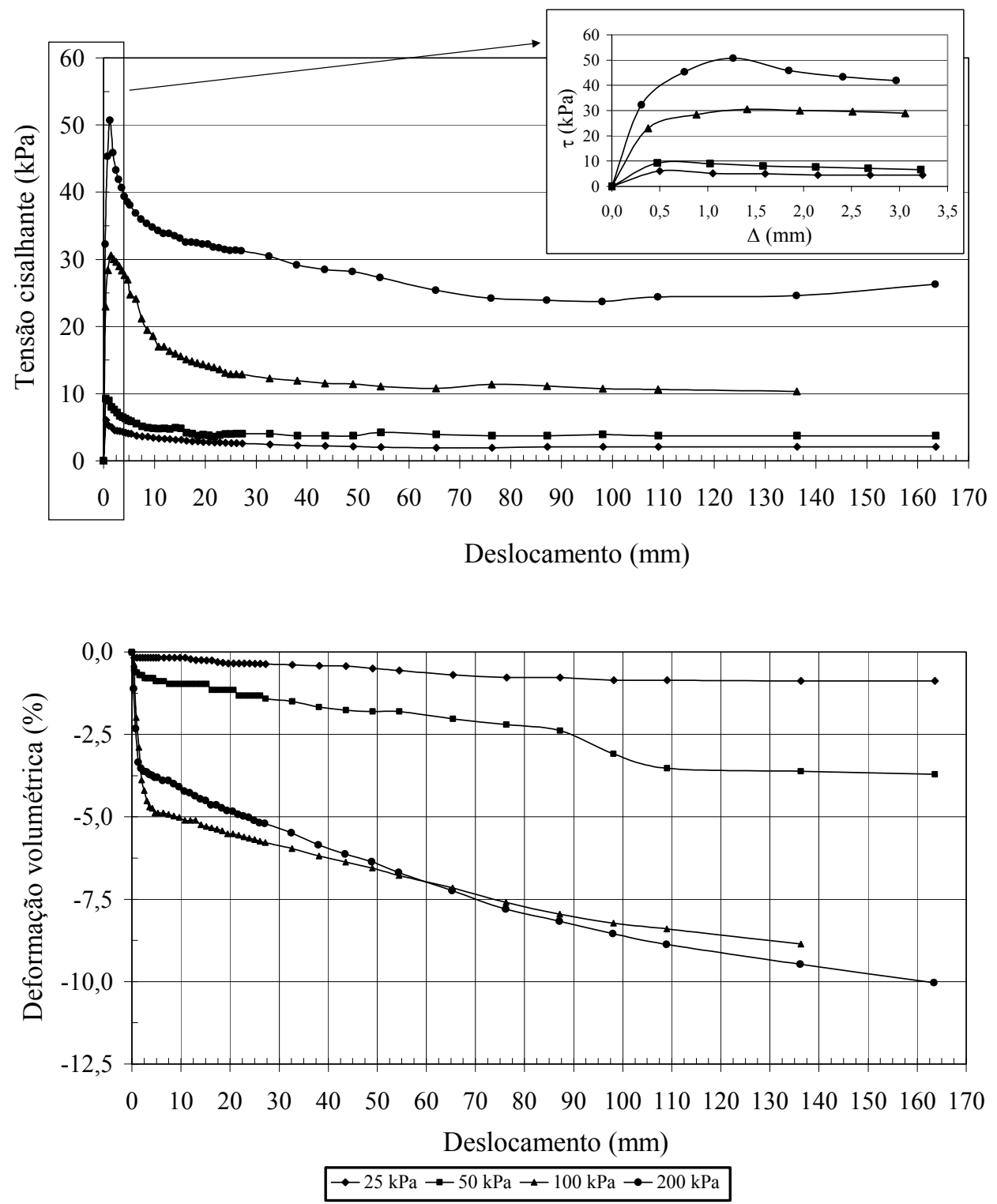

Figura 4.3.3.3. Curvas tensão cisalhante e deformação volumétrica versus deslocamento- PEAD lisa/argila- solo na umidade ótima e GC=85\%/ ensaio inundado. 


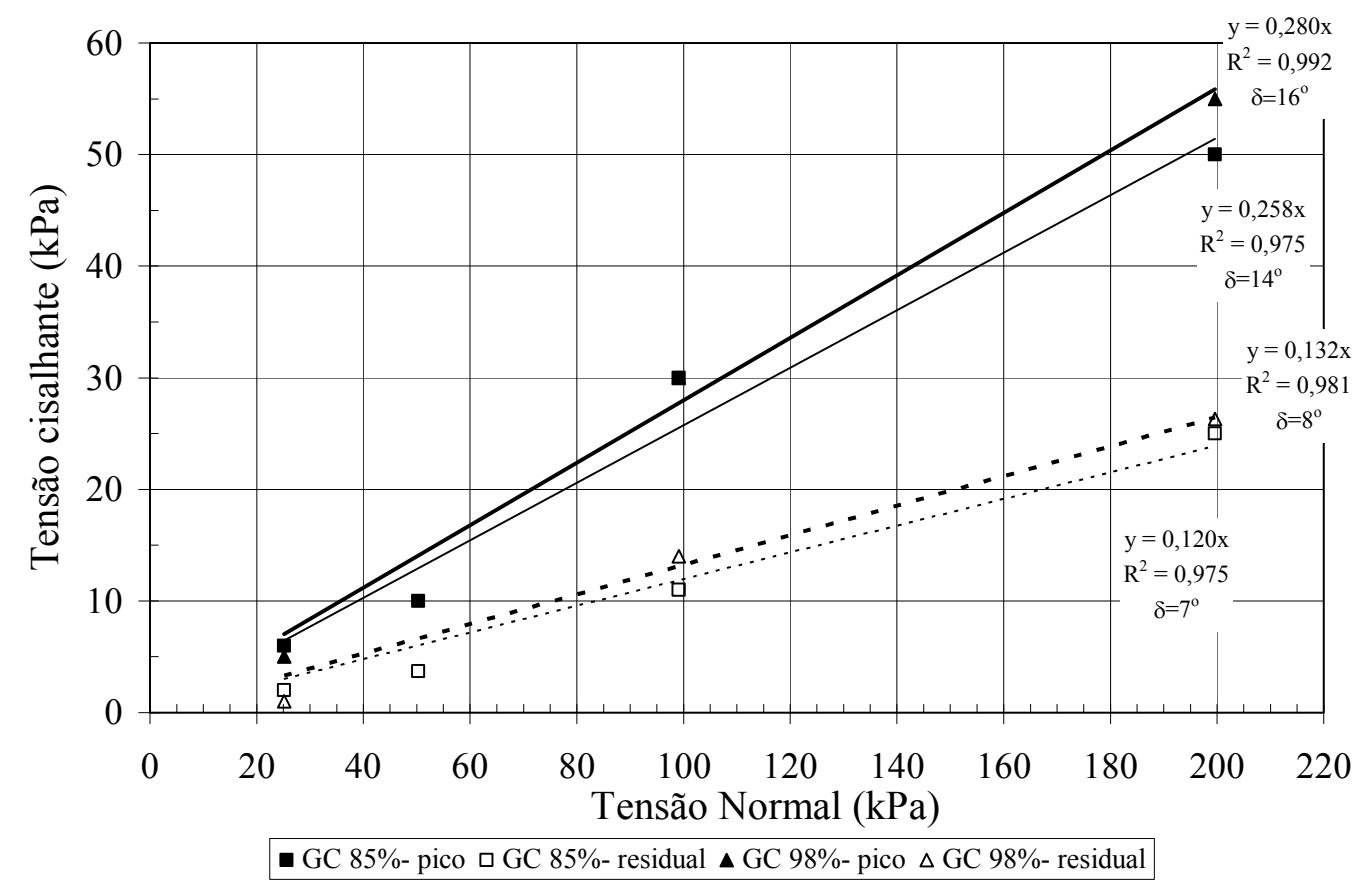

Figura 4.3.3.4. Verificação do grau de compactação- interface PVC/argilasolo na umidade ótima, ensaio inundado.

Nas Figuras 4.3.3.5 e 4.3.3.6 são apresentados os resultados referentes à interface PEAD AR/argila, realizados em condição inundada e com grau de compactação igual a $85 \%$. 


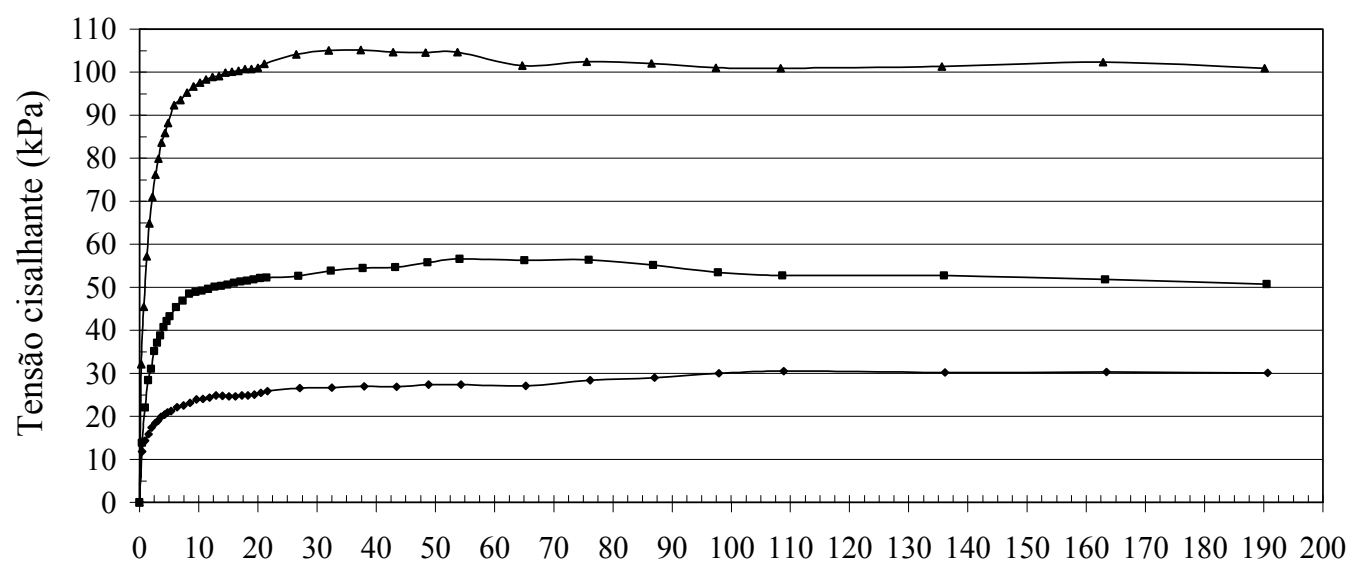

Deslocamento ( $\mathrm{mm})$

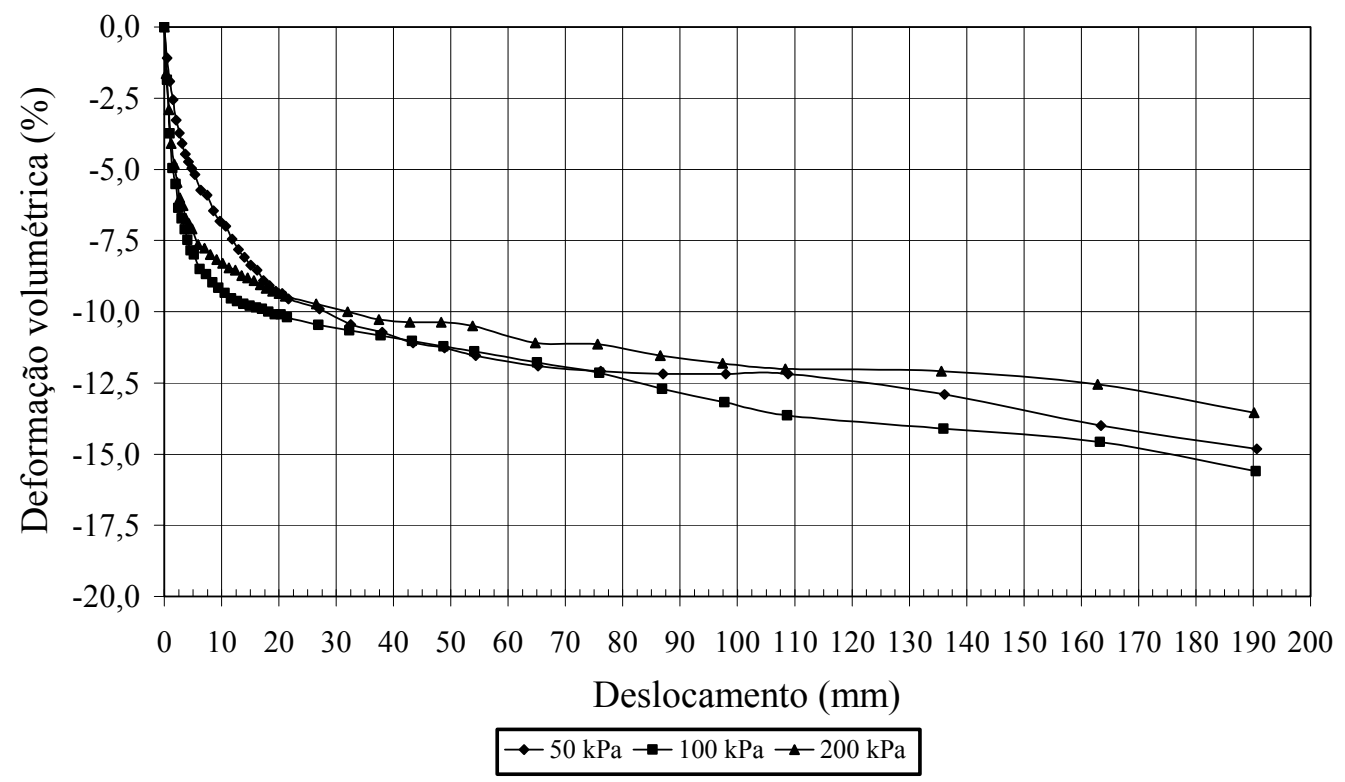

Figura 4.3.3.5. Curvas tensão cisalhante e deformação volumétrica versus deslocamento- interface PEAD AR/argila- solo na umidade ótima e GC=85\%/ ensaio inundado. 


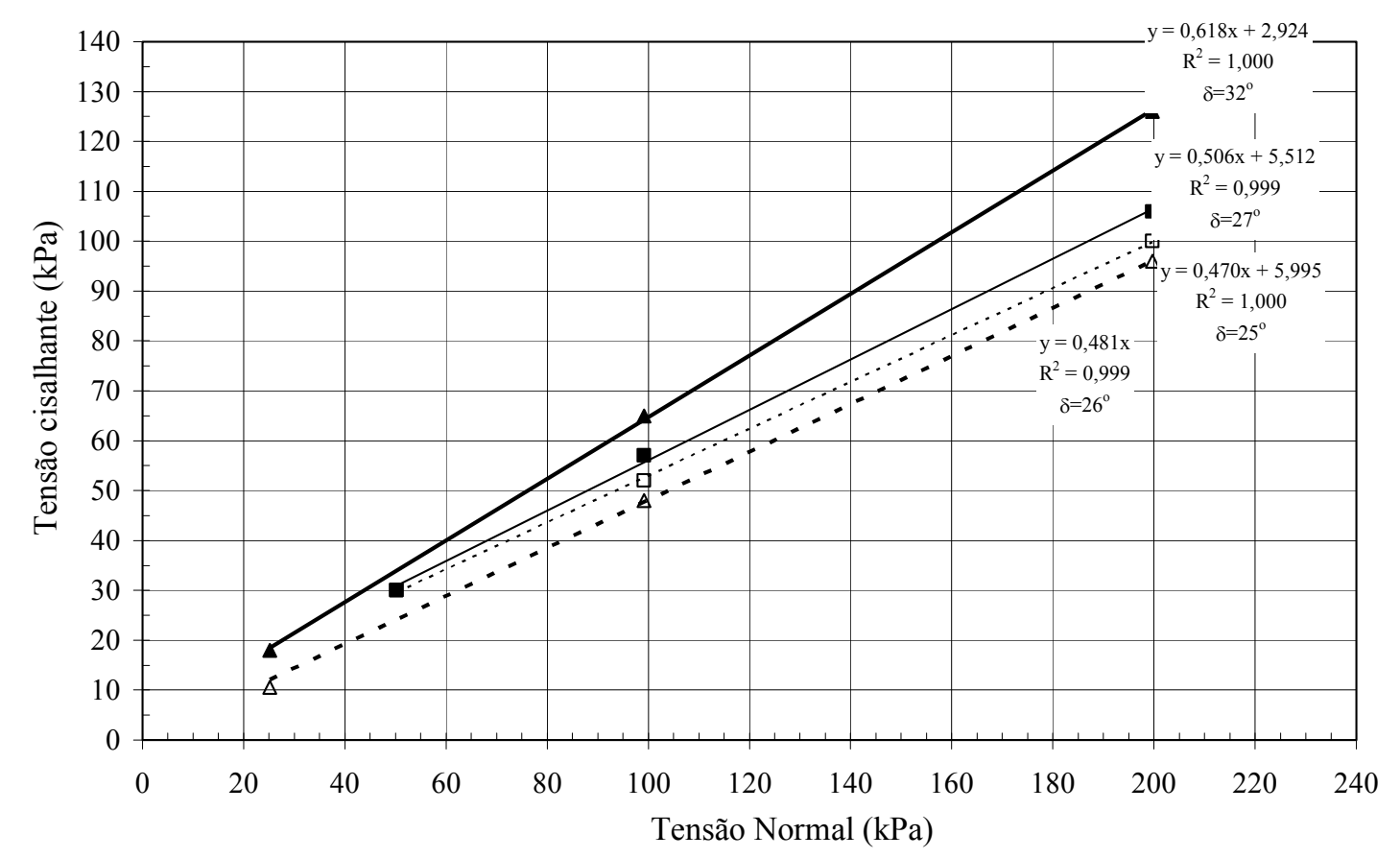

- GC 85\%-pico $\square$ GC 85\%- residual $\triangle$ GC 98\%- pico $\triangle$ GC 98\%-residual

Figura 4.3.3.6. Verificação do grau de compactação- interface PEAD AR/argila- solo na umidade ótima/ ensaio inundado.

Para este tipo de interface, diferentemente das demais, nota-se que o grau de compactação da argila influencia significativamente no comportamento da curva tensão cisalhante versus deslocamento. Nos ensaios com GC do solo igual a 85\%, verificou-se que a tensão cisalhante, atingido um máximo, tende a um valor constante com o aumento do deslizamento. Para o carregamento de 50kPa, não se observa queda de tensão pós-pico. Nos carregamentos subseqüentes, 100 e $200 \mathrm{kPa}$, observou-se uma pequena queda de tensão cisalhante, da ordem de $9 \%$ e $6 \%$, respectivamente. Verificou-se que os maiores valores de tensão cisalhante são mobilizados para deslocamentos em torno de 50 a $70 \mathrm{~mm}$, e que estes valores decrescem ligeiramente para deslocamentos a partir de $100 \mathrm{~mm}$.

Nos resultados dos ensaios com GC da argila igual a 98\%, observa-se que as tensões cisalhante de pico e residual foram mobilizadas para deslocamentos menores, em torno de 2,5 a 5,0 $\mathrm{mm}$, e $60 \mathrm{~mm}$, respectivamente. Nesta, verificou-se que após atingir a tensão cisalhante de pico ocorre um 
decréscimo de tensão acentuado, diferente do observado na interface com GC igual a $85 \%$.

Nos ensaios de interface com GC da argila igual a $85 \%$ foram obtidos valores de ângulos de atrito de pico igual a $27^{\circ}$, e residual igual a $25^{\circ}$. De outro lado, nos ensaios com GC igual a 98\% foram obtidos valores de atrito de pico e residual iguais a $32^{\circ}$ e $26^{\circ}$, respectivamente. Comparando-se estes valores, verifica-se que houve uma redução de $16 \%$ no ângulo de atrito de pico, e que o ângulo de atrito residual independe do grau de compactação nos ensaios inundados para este tipo de interface.

Na Tabela 4.3.3.1 é apresentada uma síntese dos resultados de interface realizados em condição inundada e com diferentes graus de compactação.

Tabela 4.3.3.1. Sumários dos ensaios inundados de interface- Verificação do grau de compactação.

\begin{tabular}{|c|c|c|c|c|c|c|c|c|}
\hline \multirow{2}{*}{ Interface } & \multicolumn{4}{|c|}{ GC 85\% } & \multicolumn{4}{|c|}{ GC 98\% } \\
\hline & $\begin{array}{c}C_{p} \\
(k P a)\end{array}$ & $\delta p$ & $\begin{array}{c}\mathrm{C}_{\mathrm{r}} \\
(\mathrm{kPa})\end{array}$ & $\delta r$ & $\begin{array}{c}C_{p} \\
(k P a)\end{array}$ & $\delta p$ & $\begin{array}{c}\mathrm{C}_{\mathrm{r}} \\
(\mathrm{kPa})\end{array}$ & $\delta r$ \\
\hline PVC & - & $22^{\circ}$ & - & $20^{\circ}$ & - & $26^{\circ}$ & - & $23^{\circ}$ \\
\hline PEAD lisa & - & $14^{\circ}$ & - & $7^{\circ}$ & - & $16^{\circ}$ & - & $8^{\circ}$ \\
\hline PEAD AR & 5,5 & $27^{\circ}$ & 6 & $25^{\circ}$ & 3 & $32^{\circ}$ & - & $26^{\circ}$ \\
\hline
\end{tabular}

b) Efeito do peso específico em ensaios não inundados

Abaixo são apresentados os resultados dos ensaios de interface não inundados, realizados com geomembranas de PVC, referente ao grau de compactação de $85 \%$ e umidade de $26,7 \%$ (umidade ótima). 

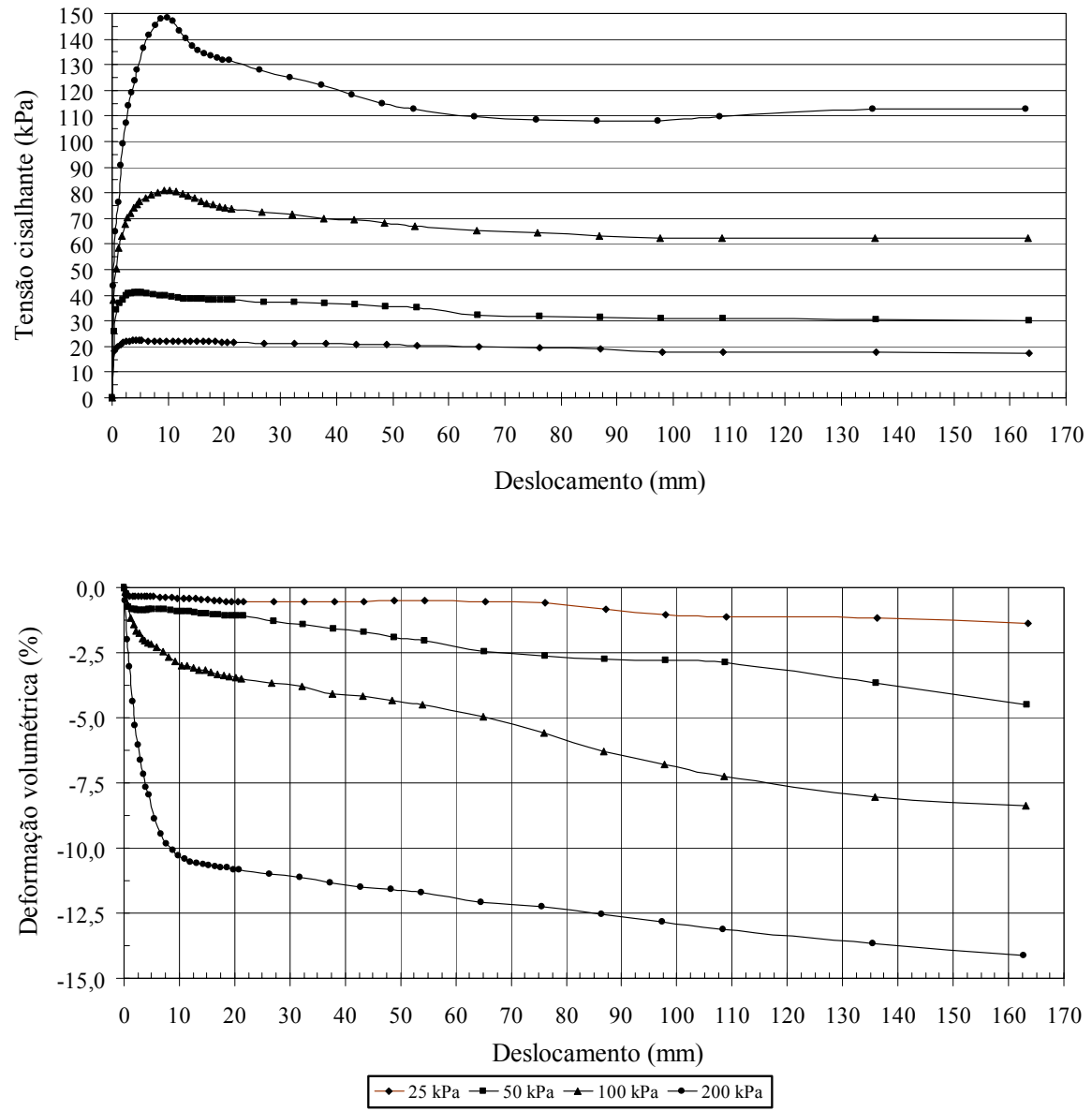

Figura 4.3.3.7. Curvas tensão cisalhante e deformação volumétrica versus deslocamento- interface PVC/argila- solo na umidade ótima e GC=85\%/ ensaio não inundado.

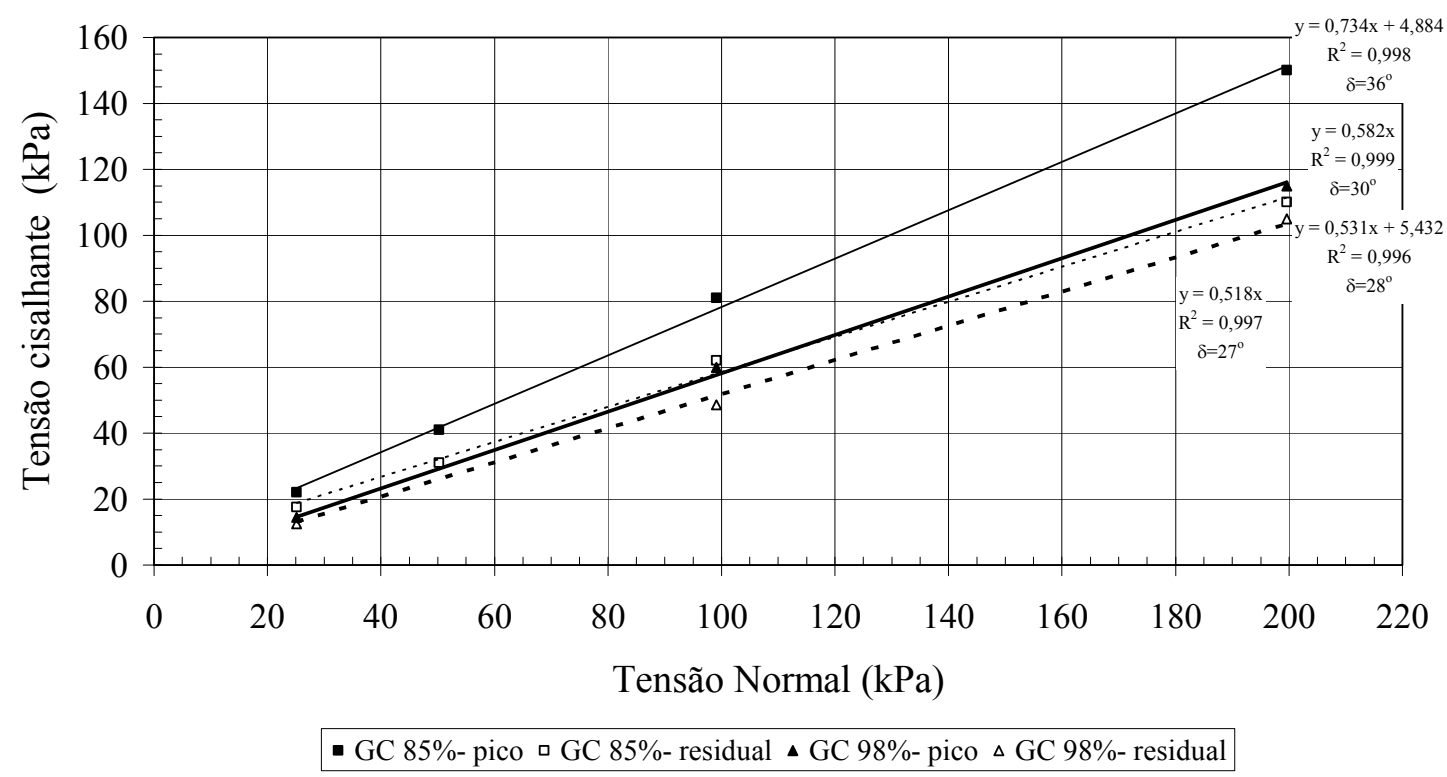

Figura 4.3.3.8. Verificação do grau de compactação- interface PVC/argilasolo na umidade ótima/ ensaio não inundado. 
Quanto ao comportamento da curva tensão cisalhante versus deslocamento, observou-se que a tensão cisalhante de pico é mobilizada entre 5,0 a $10,0 \mathrm{~mm}$ na interface com GC igual a $85 \%$. Por sua vez, no material compactado com GC de 98\% (Figura 4.3.1.1), a tensão de pico foi mobilizada com deslocamentos entre 1,5 a 3,0 mm. Percebe-se que foi necessário um menor deslocamento para mobilização da tensão de pico na interface com material compactado com $98 \%$.

Os ângulos de atrito obtidos nos ensaios com GC a $85 \%$ foram $36^{\circ}$ (pico) e $28^{\circ}$ (residual).Nos ensaios com GC igual a $98 \%$, os ângulos de atrito obtidos foram $30^{\circ}$ (pico) e $27^{\circ}$ (residual). Estes resultados mostram que o ângulo de atrito residual independe do grau de compactação. De outro lado, ao contrário do que se esperava, o ângulo de atrito de pico foi maior na interface com GC de 85\%, que pode ser atribuído a possíveis erros de leitura ou de execução do ensaio. Sugere-se, portanto, considerar com certa cautela esta constatação até que ensaios específicos possam esclarecer essa discrepância.

Nas Figuras 4.3.3.9 e 4.3.3.10 são apresentados os resultados dos ensaios de interface com geomembranas de PEAD lisa referentes ao GC de $85 \%$. 

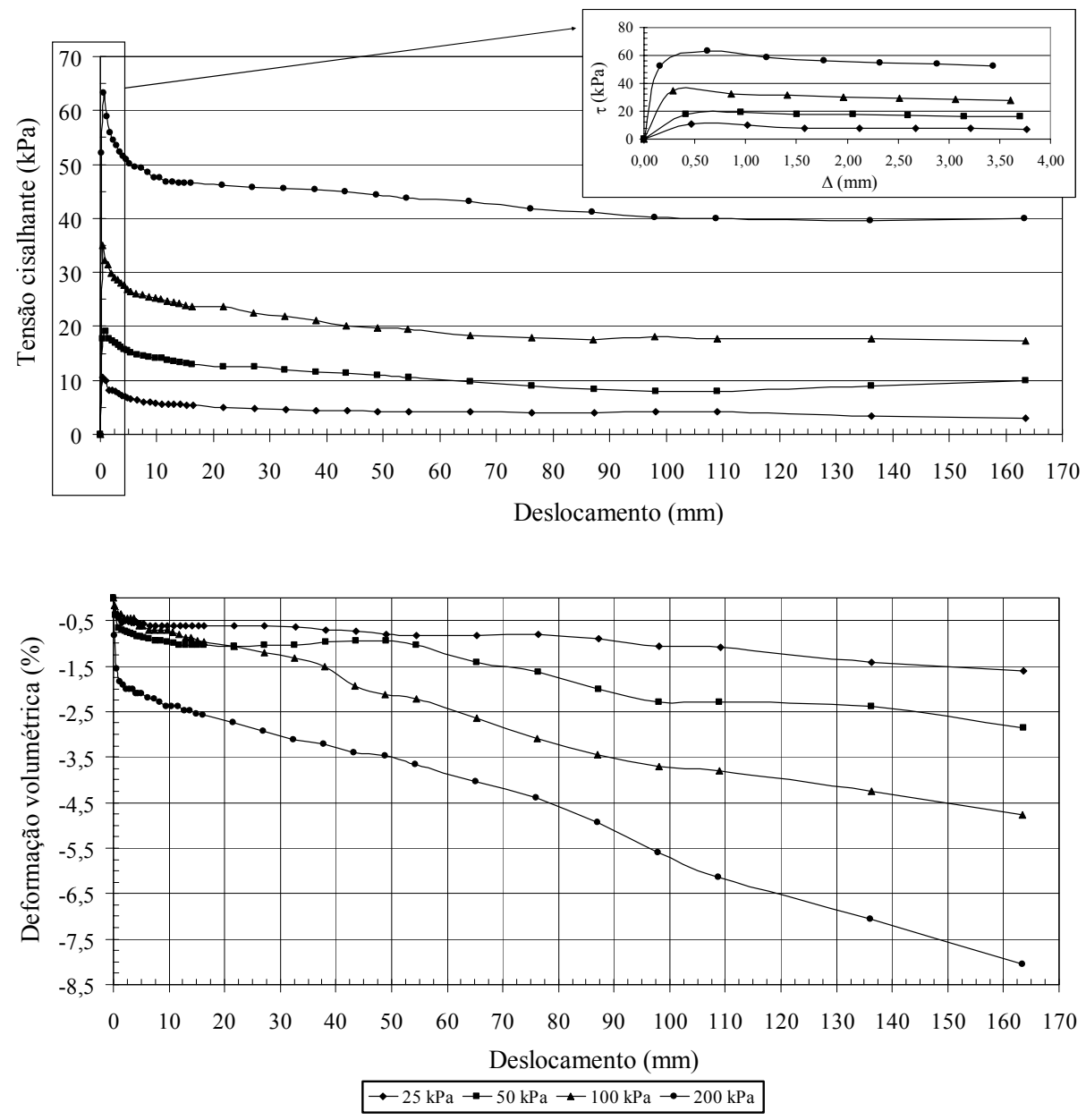

Figura 4.3.3.9. Curvas tensão cisalhante e deformação volumétrica versus deslocamento- interface PEAD/argila- solo na umidade ótima e GC=85\%/ ensaio não inundado.

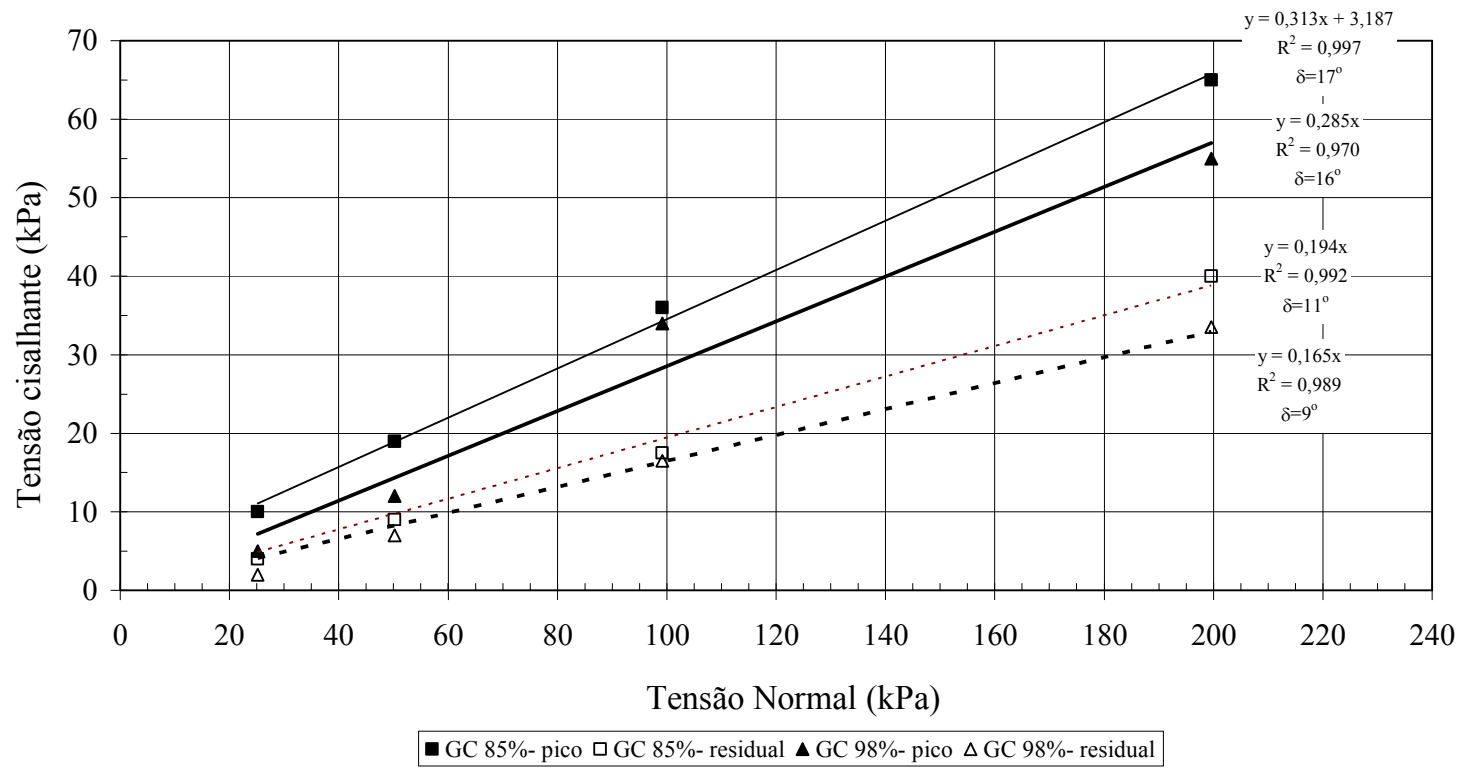

Figura 4.3.3.10. Verificação do grau de compactação - interface PEAD/argilasolo na umidade ótima/ ensaio não inundado. 
Analisando estes resultados e comparando-os com os apresentados na Figura 4.3.1.3 (GC de 98\%), observa-se que a curva apresentou o mesmo comportamento de resistência independente do grau de compactação. Verificou-se que após atingir a condição de pico, ocorre redução de tensão cisalhante até atingir a condição residual. A tensão residual foi mobilizada por volta da mesma magnitude de deslocamentos em ambas as interfaces. A tensão cisalhante de pico foi mobilizada com deslocamentos entre $0,25 \mathrm{~mm}$ a $0,50 \mathrm{~mm}$ nas interfaces com GC de $98 \%$; enquanto nas interfaces com GC de $85 \%$ é mobilizada com deslocamentos entre $0,5 \mathrm{~mm}$ a $1,0 \mathrm{~mm}$.

Para as interfaces com GC igual a $85 \%$ foram obtidos ângulos de atrito de pico igual a $17^{\circ}$, e residual igual a 11\%; enquanto nas interfaces com GC igual a $98 \%$ foram obtidos ângulos de atrito de pico e residual iguais a $16^{\circ}$ e $9^{\circ}$, respectivamente. Observou-se que em ensaios não inundados, diferentemente dos ensaios inundados, o grau de compactação não interfere nas propriedades de atrito em interfaces com geomembrana de PEAD.

\subsubsection{Efeito da umidade inicial do solo argiloso}

\section{a) Interfaces com geomembranas de PVC.}

Nas Figuras 4.3.4.1 e 4.3.4.2 são apresentadas as curvas de tensão cisalhante e de deformação volumétrica versus deslocamentos, e as envoltórias de resistência das interfaces com argila moldada na umidade $2 \%$ acima da ótima ( $w=28,7 \%)$, e realizados em condição não inundada. Estes resultados são comparados com os apresentados nas Figuras 4.3.3.7 e 4.3.3.8, os quais se referem à interface PVC/ argila, realizada sem inundação do corpo de prova, porém com umidade de moldagem igual à umidade ótima $(w=26,7 \%)$. 

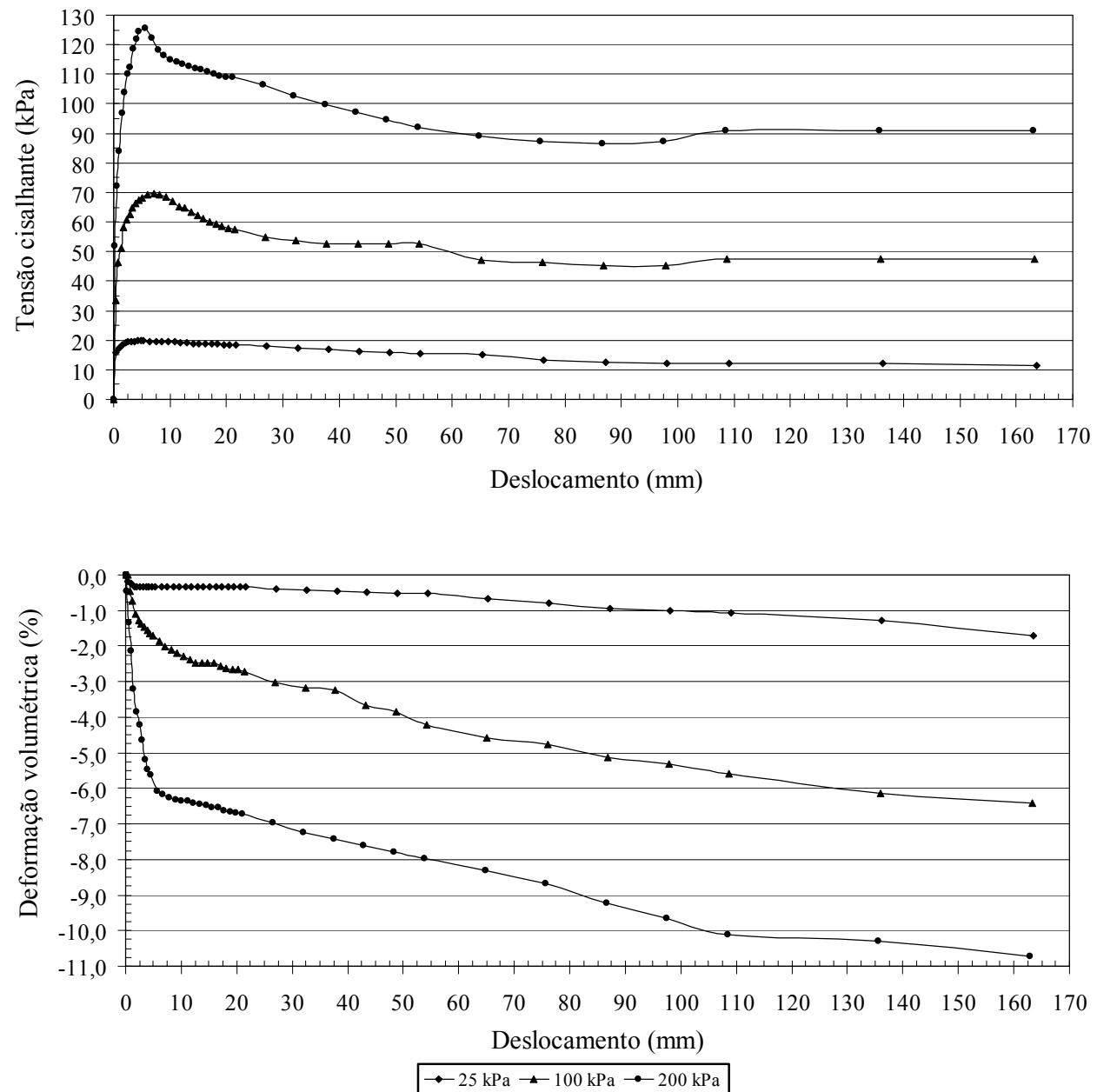

Figura 4.3.4.1. Curvas tensão cisalhante e deformação volumétrica versus

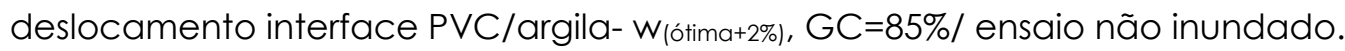

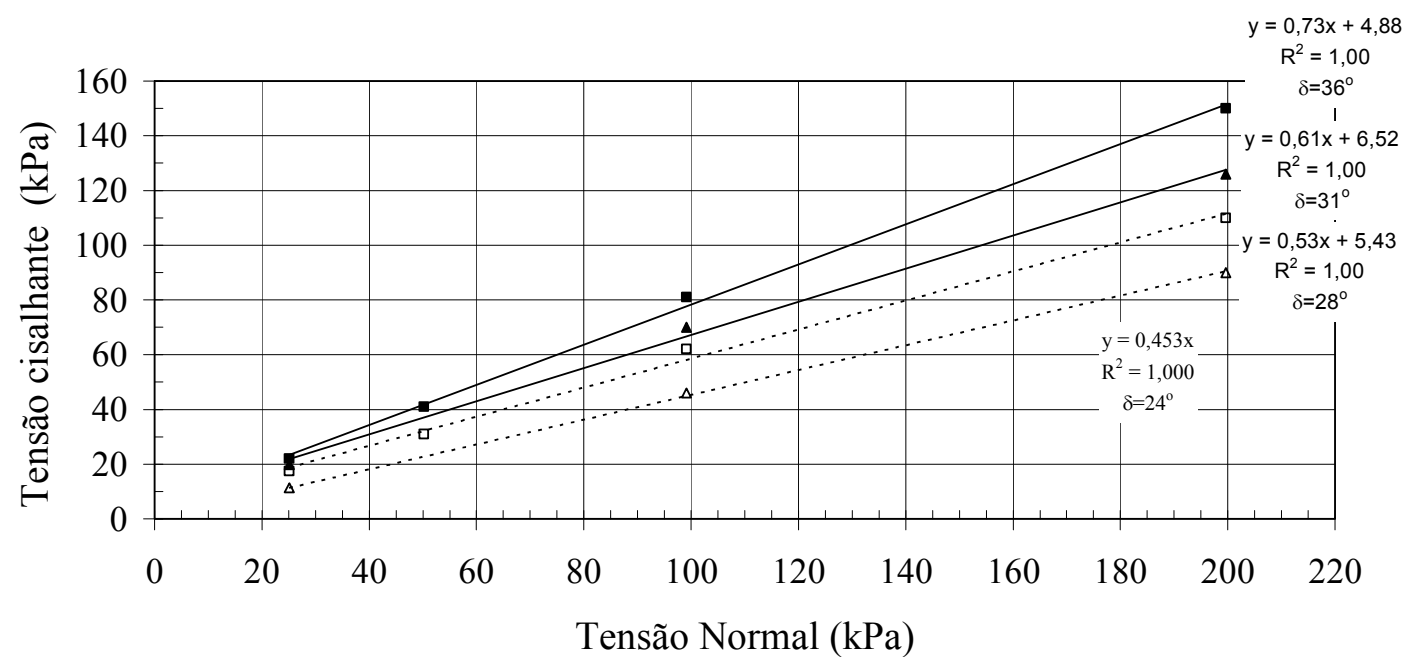

- wótima- pico $\square$ wótima-residual $\Delta \mathrm{w}($ ótima+2\%)- pico $\Delta \mathrm{w}($ ótima+2\%)- residual

Figura 4.3.4.2. Influência da umidade inicial- interface PVC/argila, GC=85\%/ ensaio não inundado. 
Com base nestes resultados, constatou-se um decréscimo nos ângulos de atrito com o aumento da umidade de material argiloso. Para a interface com argila moldada na umidade ótima, foram obtidos ângulos de atrito de pico e residuais iguais a $36^{\circ}$ e $28^{\circ}$, respectivamente. Por sua vez, no material moldado com umidade $2 \%$ acima da ótima, foram obtidos ângulos iguais a $31^{\circ}$ e $24^{\circ}$ referentes à condição de pico e residual. Isto corresponde a uma perda de resistência de aproximadamente $14 \%$ nos ângulos de atrito de pico e residual. Também se pôde observar que o comportamento de tensão cisalhante independe da umidade inicial do solo argiloso, verificando-se a mesma magnitude de deslocamentos nas interfaces com material moldado na umidade ótima e $2 \%$ acima da ótima.

Nas Figuras 4.3.4.3 e 4.3.4.4 são apresentados os resultados da mesma interface, com argila moldada na umidade $2 \%$ acima da ótima ( $w=28,7 \%$ ), entretanto realizados em condição inundada.
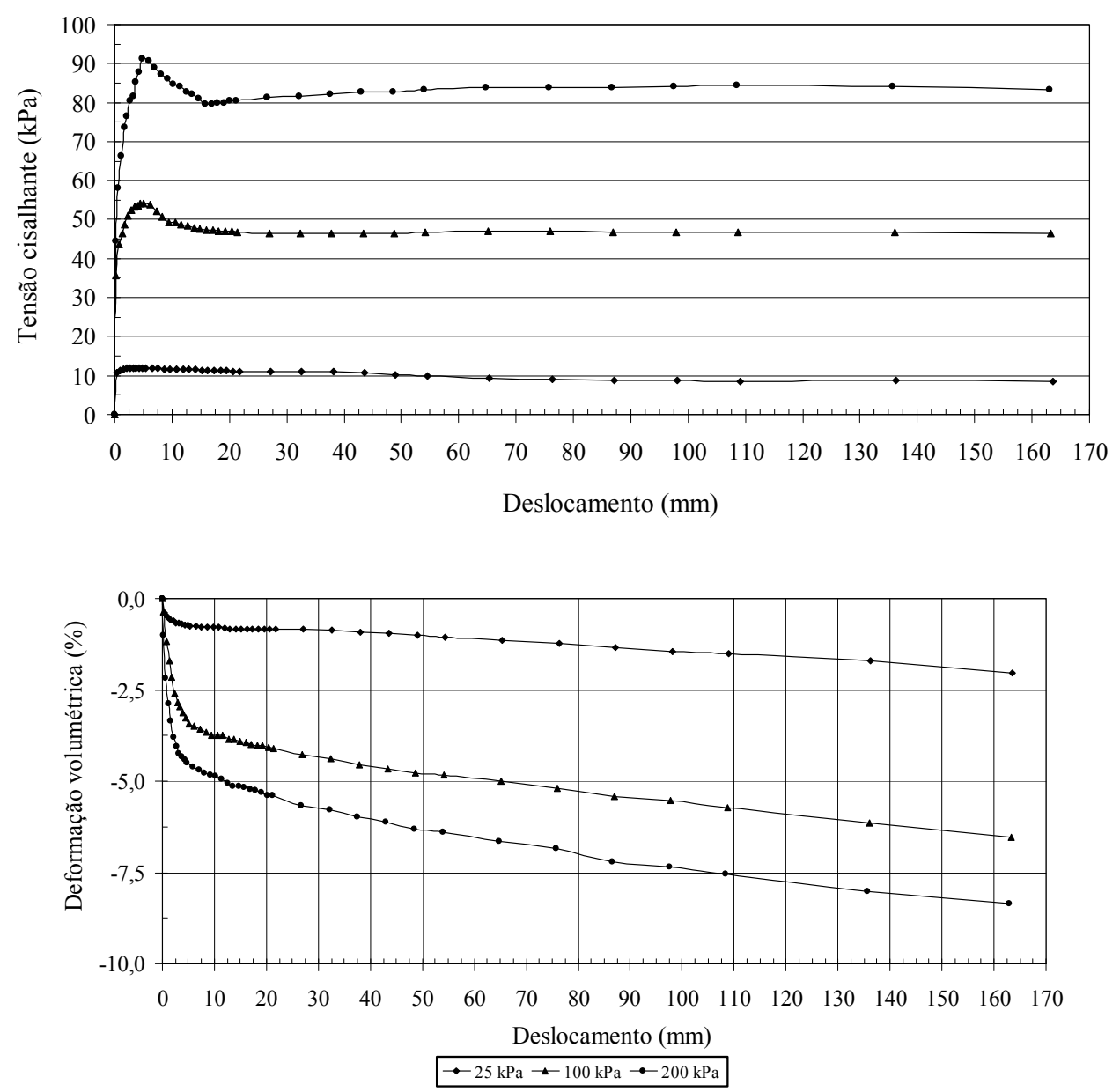

Figura 4.3.4.3. Curvas tensão cisalhante e deformação volumétrica versus

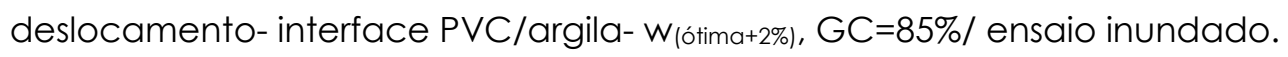




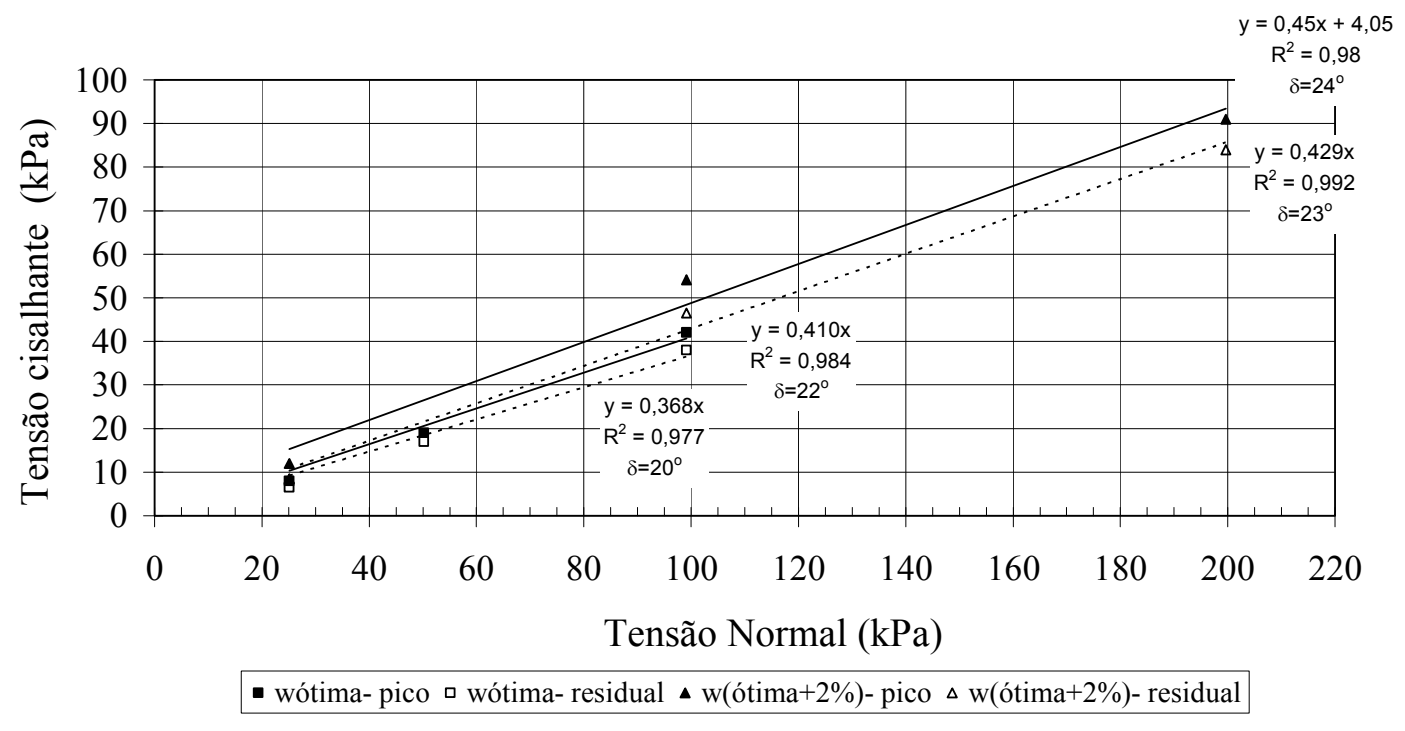

Figura 4.3.4.4. Influência da umidade inicial - interface PVC/argila- W(ótima+2\%), $G C=85 \%$ / ensaio inundado.

Comparando-se estes resultados com os ensaios inundados realizados com material moldado na umidade ótima (Figura 4.3.3.1), verificou-se que os ângulos de atrito de pico e residual apresentam a mesma ordem de grandeza nos materiais compactados na umidade ótima e $2 \%$ acima da ótima.

Quanto à influência da umidade de compactação, pôde-se averiguar que nos ensaios de interface não inundados com geomembranas de PVC, a resistência de interface diminui com o aumento da umidade. Todavia, para os ensaios inundados, verificou-se que a umidade de compactação não interfere nas propriedades de resistência, observando-se valores de ângulos de atrito semelhantes nas interfaces com solo na umidade ótima e $2 \%$ acima da ótima.

\section{b) Interfaces com geomembranas de PEAD.}

Nas Figuras 4.3.4.5 e 4.3.4.6 são apresentadas as curvas de tensão cisalhante e de deformação volumétrica versus deslocamentos, e as envoltórias de resistência das interfaces com argila moldada na umidade $2 \%$ acima da ótima (w=28,7\%), realizadas em condição não inundada. 

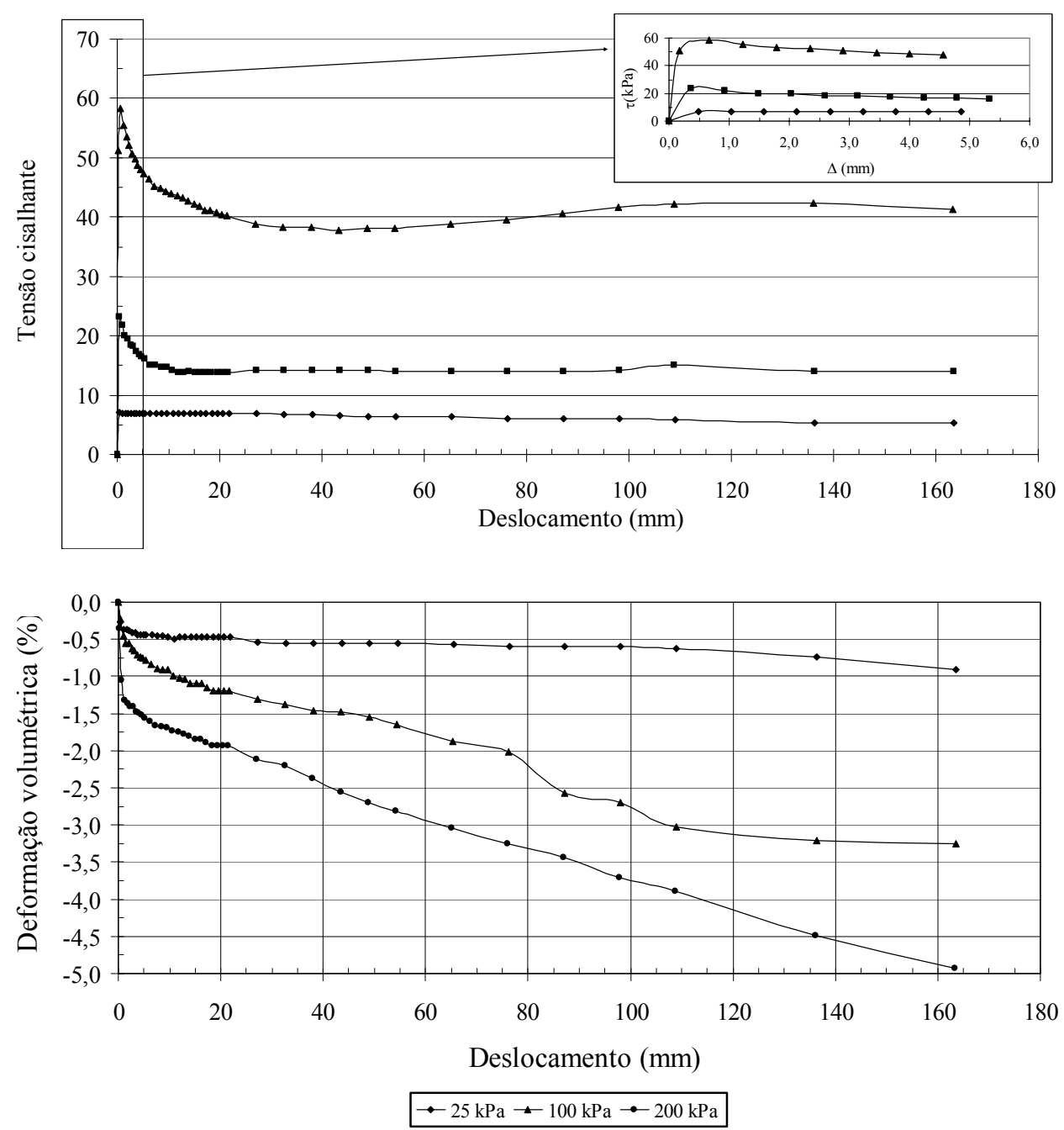

Figura 4.3.4.5. Curvas tensão cisalhante e deformação volumétrica versus

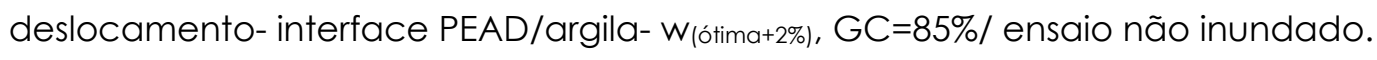

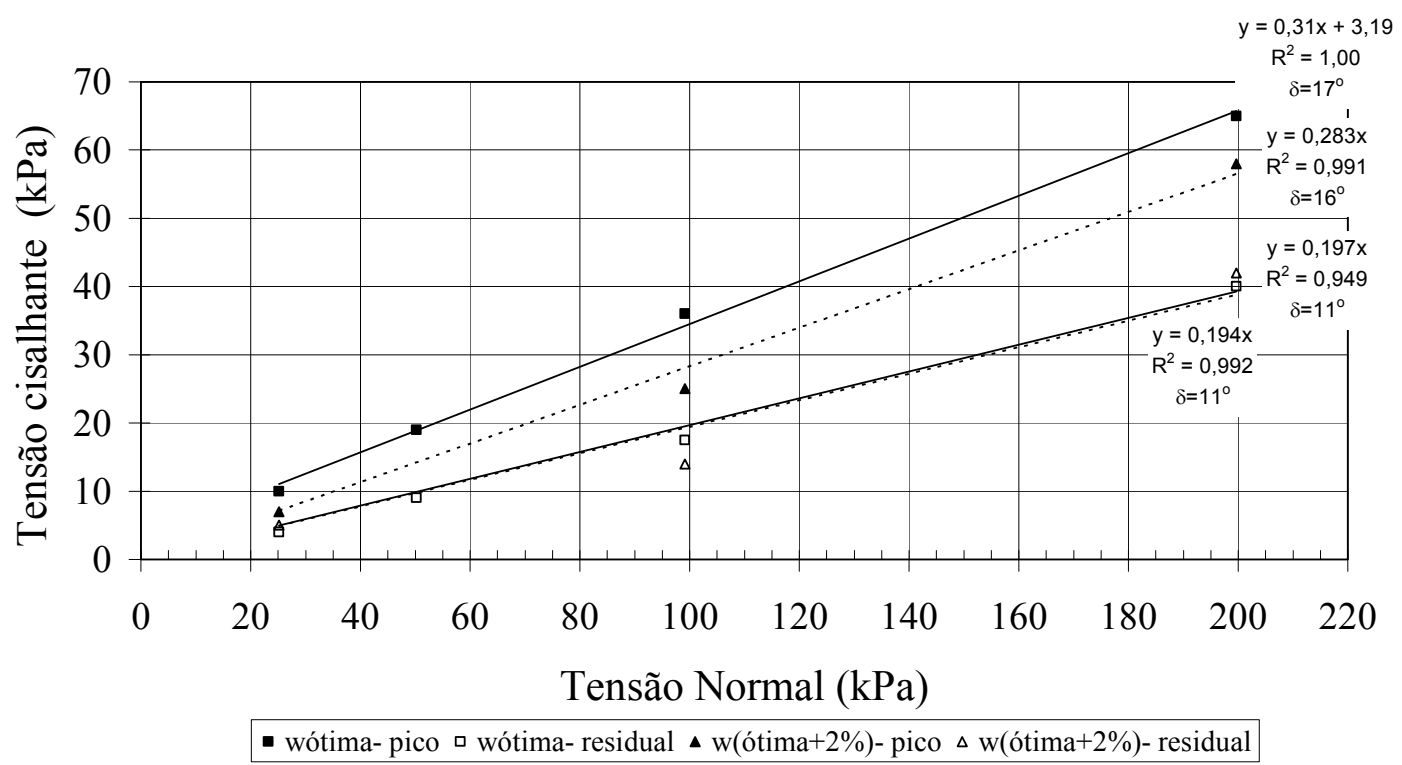

Figura 4.3.4.6. Influência da umidade inicial- interface PEAD/argila- W(ótima+2\%), GC=85\%/ ensaio não inundado. 
Analisando estes resultados com os apresentados na Figura 4.3.3.9 (material moldado na umidade ótima e ensaio não inundado), pôde-se observar que a umidade inicial do solo argiloso não interfere no comportamento da curva tensão cisalhante versus deslocamento. As tensões cisalhantes de pico e residual mobilizadas foram mobilizadas com a mesma magnitude de deslocamentos, independente do teor de umidade inicial. Dos ensaios realizados em condição não inundada, foram obtidos para a condição de pico ângulos iguais a $17^{\circ}$ e $16^{\circ}$, relativos a umidade ótima e $2 \%$ acima da ótima, respectivamente. Desta forma, verificou-se que a variação no ângulo de atrito de pico devido à umidade pode ser considerada desprezível. Para a condição residual foram obtidos os mesmos ângulos de atrito em ambas as condições de ensaio $\left(11^{\circ}\right)$.

Nas Figuras 4.3.4.7 e 4.3.4.8 são apresentadas as curvas de tensão cisalhante e de deformação volumétrica versus deslocamentos, e as envoltórias de resistência das interfaces com argila moldada na umidade $2 \%$ acima da ótima ( $w=28,7 \%$ ), e realizados em condição inundada.

Nos ensaios inundados, obteve-se um aumento de $3^{\circ}$ no ângulo de atrito residual com o aumento da umidade. Já para a condição de pico, verificou-se um aumento de $2^{\circ}$ de no ângulo de atrito com a diminuição da umidade. Este comportamento errático sugere que a umidade inicial do solo argiloso não influencia no comportamento de resistência de interface com geomembrana de PEAD lisa para condições de ensaio inundadas.

Sintetizando-se os resultados, observa-se que, em interfaces envolvendo geomembranas de PEAD, o efeito da umidade inicial do solo argiloso não interfere nas propriedades de atrito, tanto sob condição inundada quanto não inundada. 

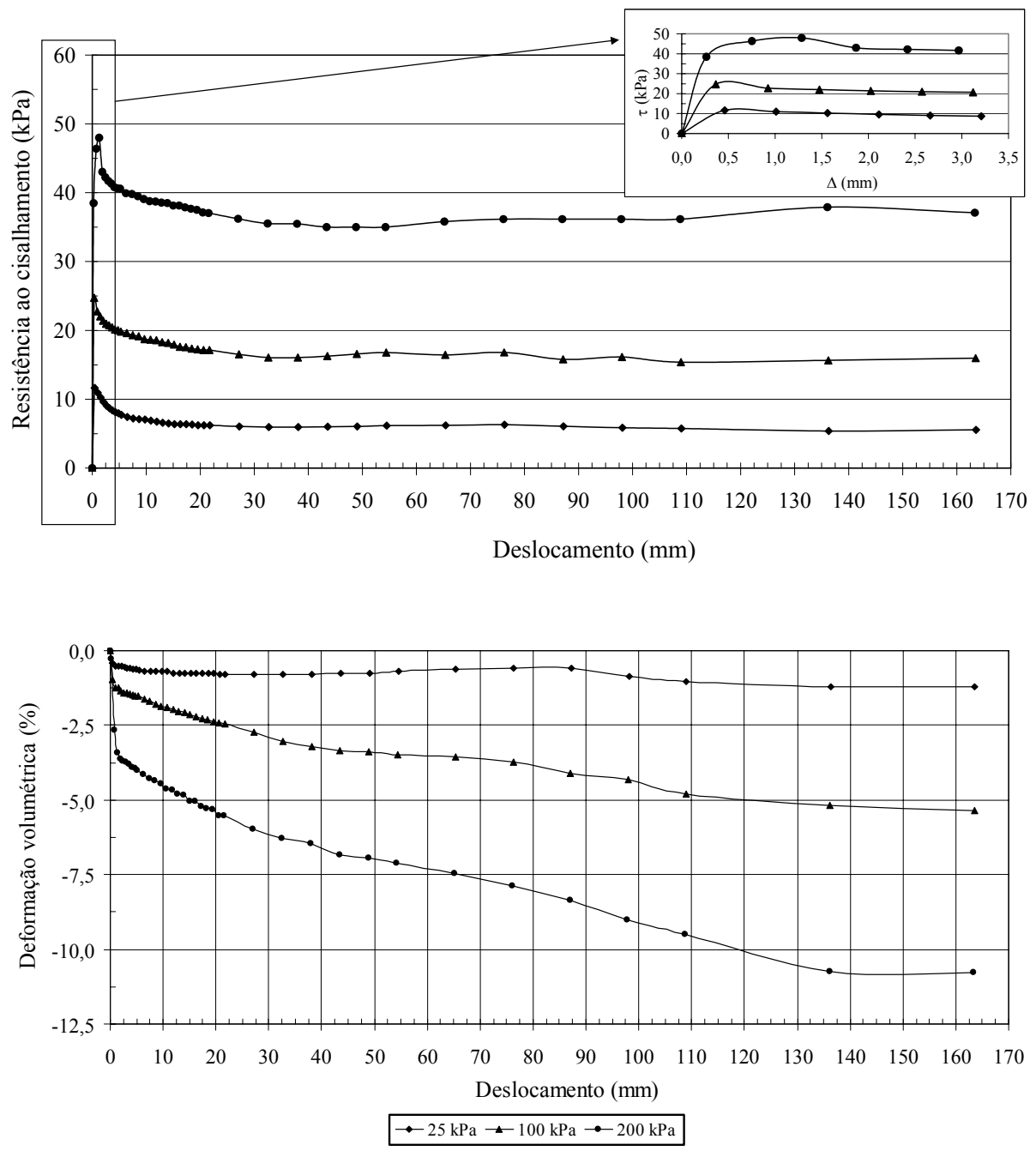

Figura 4.3.4.7. Curvas tensão cisalhante e deformação volumétrica versus

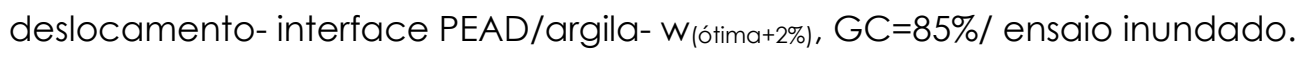

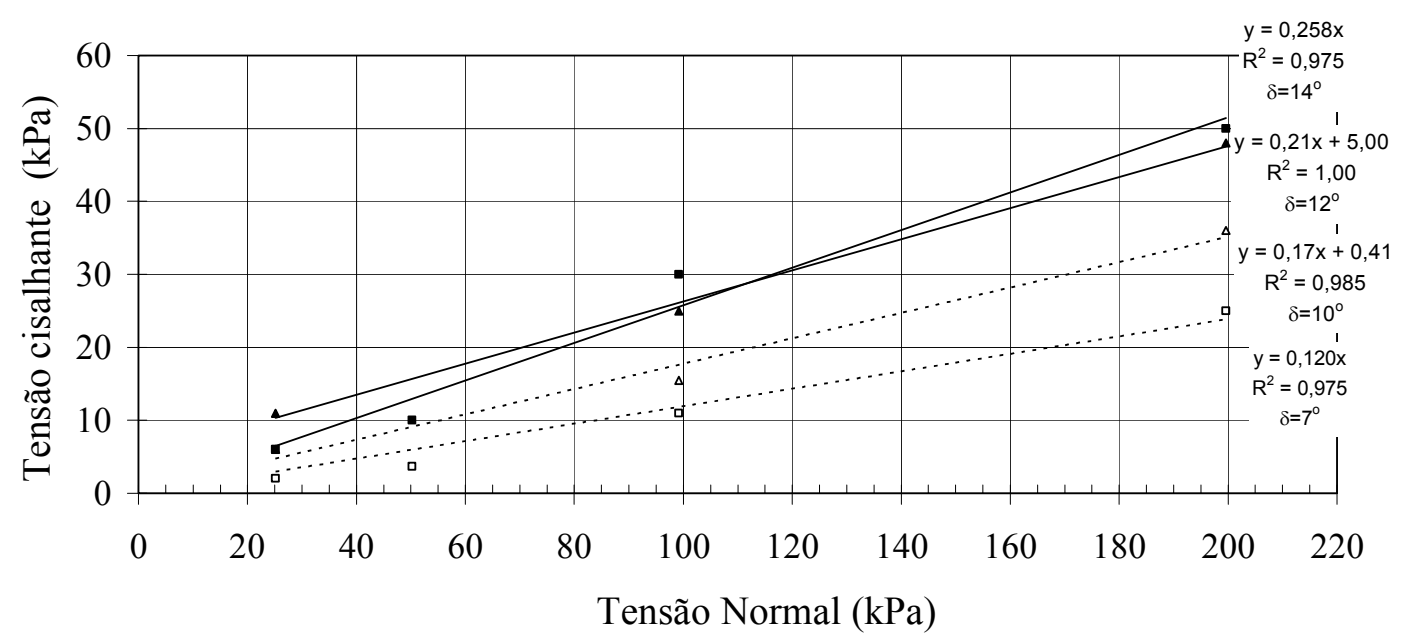

$\Delta \mathrm{w}($ ótima $+2 \%)$ - pico $\Delta \mathrm{w}($ ótima $+2 \%)$ - residual • wótima- pico $\square$ wótima- residual

Figura 4.3.4.8. Influência da umidade inicial- interface PEAD/argila- W(ótima+2\%), GC $=85 \%$ / ensaio inundado. 
A Tabela 4.3.4.1 apresenta uma síntese das variações da umidade inicial do solo nas interfaces com geomembranas de PVC e PEAD lisa.

Tabela 4.3.4.1. Verificação do efeito da umidade inicial do material argiloso para amostras moldadas com GC $=85 \%$.

\begin{tabular}{|c|c|c|c|c|c|c|c|c|c|}
\hline \multirow{3}{*}{ GM } & \multirow{3}{*}{$\begin{array}{l}\text { Umidade de } \\
\text { compactação }\end{array}$} & \multicolumn{8}{|c|}{ Condição do Ensaio } \\
\hline & & \multicolumn{4}{|c|}{ Inundado } & \multicolumn{4}{|c|}{ Não Inundado } \\
\hline & & $\begin{array}{c}\mathrm{Cp}_{\mathrm{p}} \\
(\mathrm{kPa})\end{array}$ & $\delta p$ & $\begin{array}{c}\mathrm{C}_{\mathrm{r}} \\
(\mathrm{kPa})\end{array}$ & $\delta r$ & $\begin{array}{c}\mathrm{Cp}_{\mathrm{p}} \\
(\mathrm{kPa})\end{array}$ & $\delta p$ & $\begin{array}{c}\mathrm{C}_{\mathrm{r}} \\
(\mathrm{kPa})\end{array}$ & $\delta r$ \\
\hline \multirow{2}{*}{ PVC } & $\begin{array}{l}\text { w ótima } \\
(26,7 \%)\end{array}$ & - & $22^{\circ}$ & - & $20^{\circ}$ & 4,9 & $36^{\circ}$ & 5,43 & $28^{\circ}$ \\
\hline & $\begin{array}{l}\text { w ótima+2\% } \\
(28,7 \%)\end{array}$ & 4 & $24^{\circ}$ & - & $23^{\circ}$ & 6,5 & $31^{\circ}$ & - & $24^{\circ}$ \\
\hline \multirow{2}{*}{ PEAD } & $\begin{array}{l}\text { w ótima } \\
(26,7 \%)\end{array}$ & - & $14^{\circ}$ & - & $7^{\circ}$ & 3,2 & $17^{\circ}$ & - & $11^{\circ}$ \\
\hline & $\begin{array}{l}\text { w ótima+2\% } \\
(28,7 \%)\end{array}$ & 5 & $12^{\circ}$ & 0,4 & $10^{\circ}$ & - & $16^{\circ}$ & - & $11^{\circ}$ \\
\hline
\end{tabular}

\subsubsection{Comparação com ensaios de cisalhamento direto}

A título de comparação, são apresentados alguns resultados de ensaios de interface obtidos por cisalhamento direto. A Figura 4.3.5.1 apresenta as curvas de tensão cisalhante versus deslocamentos obtidas por ensaios de cisalhamento direto, referentes à interface PEAD lisa/argila. Os ensaios de cisalhamento direto foram realizados com adensamento da amostra e velocidade de cisalhamento de $0,5 \mathrm{~mm} / \mathrm{min}$, e com solo moldado em umidade $2 \%$ acima da ótima. Estes resultados são comparados com os ensaios de ring shear apresentados na Figura 4.3.2.3 e 4.3.2.4. Nos ensaios de ring shear, o solo foi moldado na umidade ótima e cisalhado com velocidade de $1,653 \mathrm{~mm} / \mathrm{min}$. Em ambos os ensaios, a argila foi compactada com GC igual a $98 \%\left(\gamma_{d}=15,6 \mathrm{kN} / \mathrm{m}^{3}\right)$. 

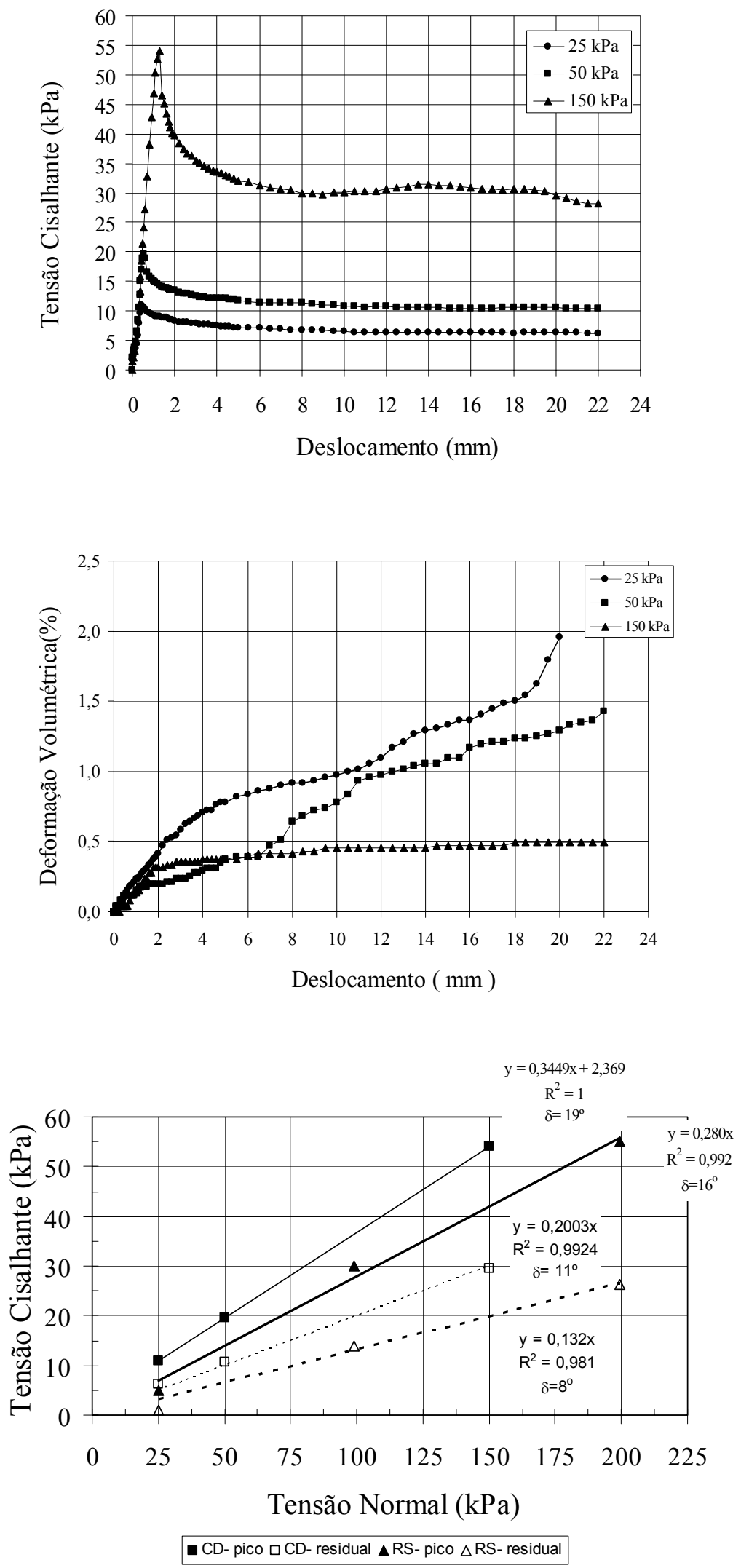

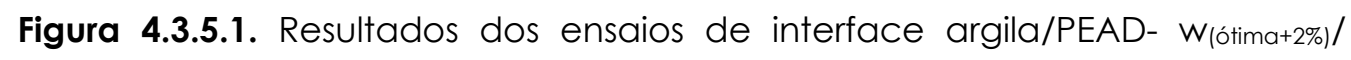
inundado- Cisalhamento Direto. 
Comparando-se as curvas de tensão cisalhante obtidas, observou-se que o comportamento de resistência é semelhante em ambos os ensaios, atingindo-se uma tensão cisalhante máxima seguida de decréscimo de tensão até alcançar a condição residual. Verificou-se que a tensão cisalhante de pico é mobilizada para deslocamentos entre 0,5 a $1,5 \mathrm{~mm}$, nos ensaios de cisalhamento direto; enquanto nos ensaios de ring shear, a tensão cisalhante de pico foi mobilizada com deslocamentos entre 0,2 a $0,5 \mathrm{~mm}$.

Observou-se que as envoltórias de resistência de pico e residual são lineares nos dois tipos de ensaios. Nos ensaios com ring shear foram obtidos ângulos de atrito de pico e residual iguais a $16^{\circ}(0,50)$ e $8^{\circ}(0,23)$, respectivamente. Os valores obtidos nos ensaios com cisalhamento direto foram aproximadamente $19^{\circ}(0,59)$ e $11^{\circ}(0,34)$, respectivos à condição de pico e residual. Nota-se que os valores encontrados nos ensaios com cisalhamento direto foram ligeiramente maiores do que os obtidos nos ensaios de ring shear.

Na Figura 4.3.5.2 são apresentados os resultados dos ensaios de cisalhamento direto correspondentes à interface com geomembrana texturizada PEAD AR. Nestes, o solo foi compactado com umidade igual a $26,7 \%$ (umidade ótima) e grau de compactação igual a $98 \%\left(\gamma_{d}=15,6 \mathrm{kN} / \mathrm{m}^{3}\right)$, e sem inundação do corpo de prova. 

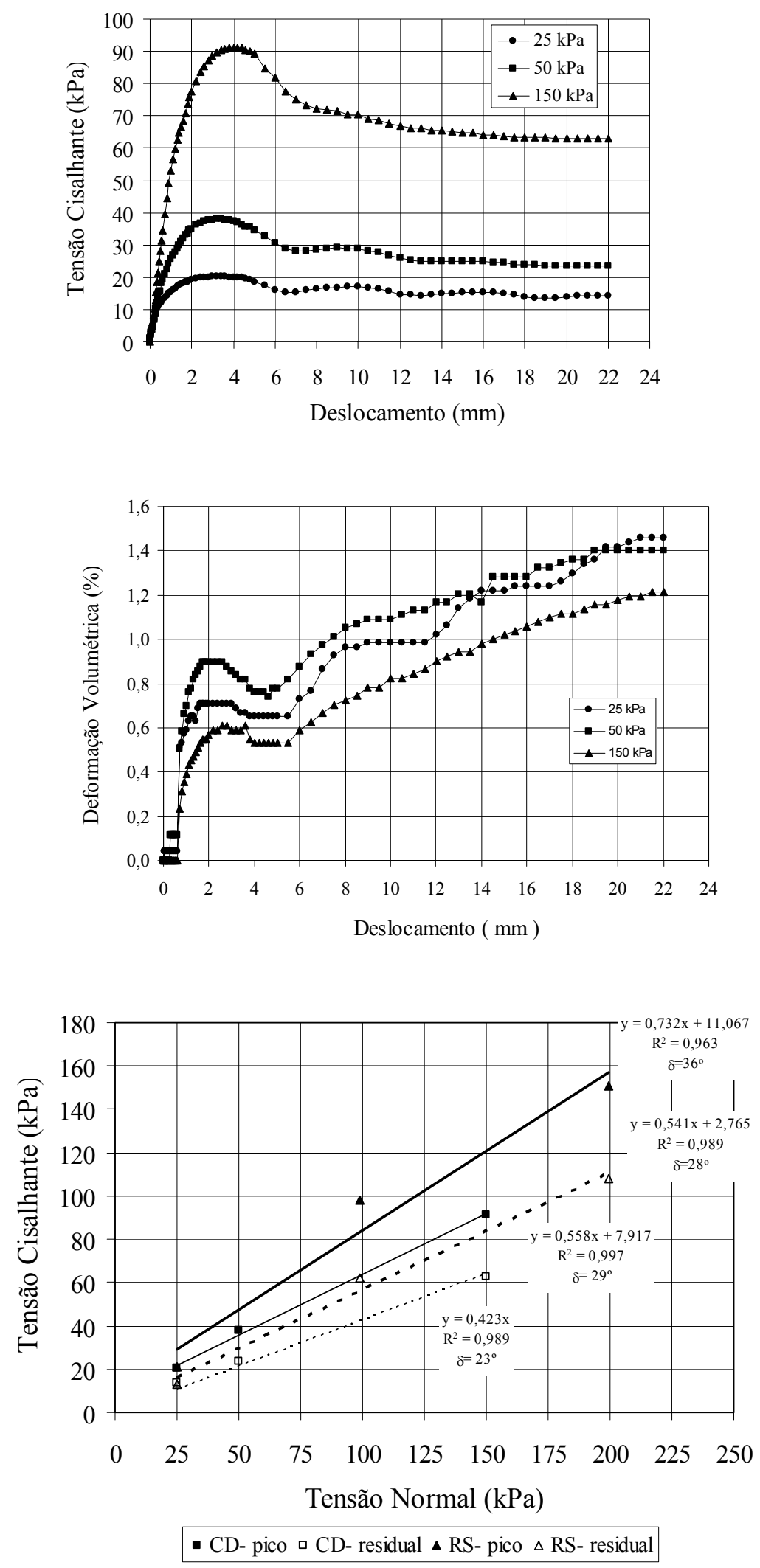

Figura 4.3.5.2. Resultados dos ensaios de interface argila/PEAD AR- solo na umidade ótima/ não inundado- Cisalhamento Direto. 
Verificou-se que ambos os ensaios, cisalhamento direto e ring shear (Figura 4.3.1.7), apresentam um comportamento semelhante de resistência de interface. Constata-se que a tensão cisalhante, após atingir a condição de pico, apresenta uma significativa queda de resistência pós-pico.

Observaram-se, em ambos os resultados, que as envoltórias de resistência também são lineares. Na envoltória obtida pelo cisalhamento direto, verificou-se um intercepto de coesão para a condição de pico (8kPa). Nas envoltórias de resistência obtidas no ring shear foi observado um intercepto de coesão para a condição de pico de $11 \mathrm{kPa}$, e para a condição residual de 3kPa, aproximadamente. Foram obtidos ângulos de atrito de pico e residuais iguais a $29^{\circ}(0,91)$ e $23^{\circ}(0,72)$ nos ensaios de cisalhamento direto, e $36^{\circ}(0,92)$ e $28^{\circ}(0,72)$ nos ensaios de ring shear.

Na Figura 4.3.5.3 são apresentados os resultados dos ensaios de cisalhamento direto da interface com geomembranas de PEAD AR, realizados sob condição inundada. Os solo foi compactado com GC igual a $98 \%$ e na umidade ótima ( $w=26,7 \%)$.

Comparando-se as curvas obtidas pelo cisalhamento direto com as curvas obtidas pelo ring shear (Figura 4.3.2.5), observa-se que a tensão cisalhante de pico foi mobilizada com deslocamentos entre $2,5 \mathrm{~mm}$ a $4,0 \mathrm{~mm}$ em ambos os ensaios. Devido à limitação dos deslocamentos, a tensão residual foi considerada como ocorrendo aos $20 \mathrm{~mm}$ de deslocamento nos ensaios de cisalhamento direto, tornando-se constante a partir dos $10 \mathrm{~mm}$ de deslocamento. No entanto, pôde-se observar, através das curvas apresentadas pelo ring shear, que a tensão residual somente é mobilizada a partir de $80 \mathrm{~mm}$ de deslocamento para este tipo de interface.

Os valores de ângulos de atrito obtidos nos ensaios de cisalhamento direto foram $28^{\circ}$ (pico) e $24^{\circ}$ (residual). Também foi observado um intercepto de coesão de $3,50 \mathrm{kPa}$ para a condição de pico. Nos ensaios de ring shear, os ângulos obtidos foram $32^{\circ}$ (pico) e $26^{\circ}$ (residual), sendo também observado um intercepto de coesão na envoltória de resistência de pico (1 lkPa), porém maior do que observado nos ensaios de cisalhamento direto.

Nestes resultados, constatou-se que os valores dos ângulos de atrito obtidos por cisalhamento direto foram ligeiramente menores do que os obtidos 
pelo ring shear. Contudo deve-se ressaltar que o lado da geomembrana utilizado foi o menos áspero, o que confere menor atrito.
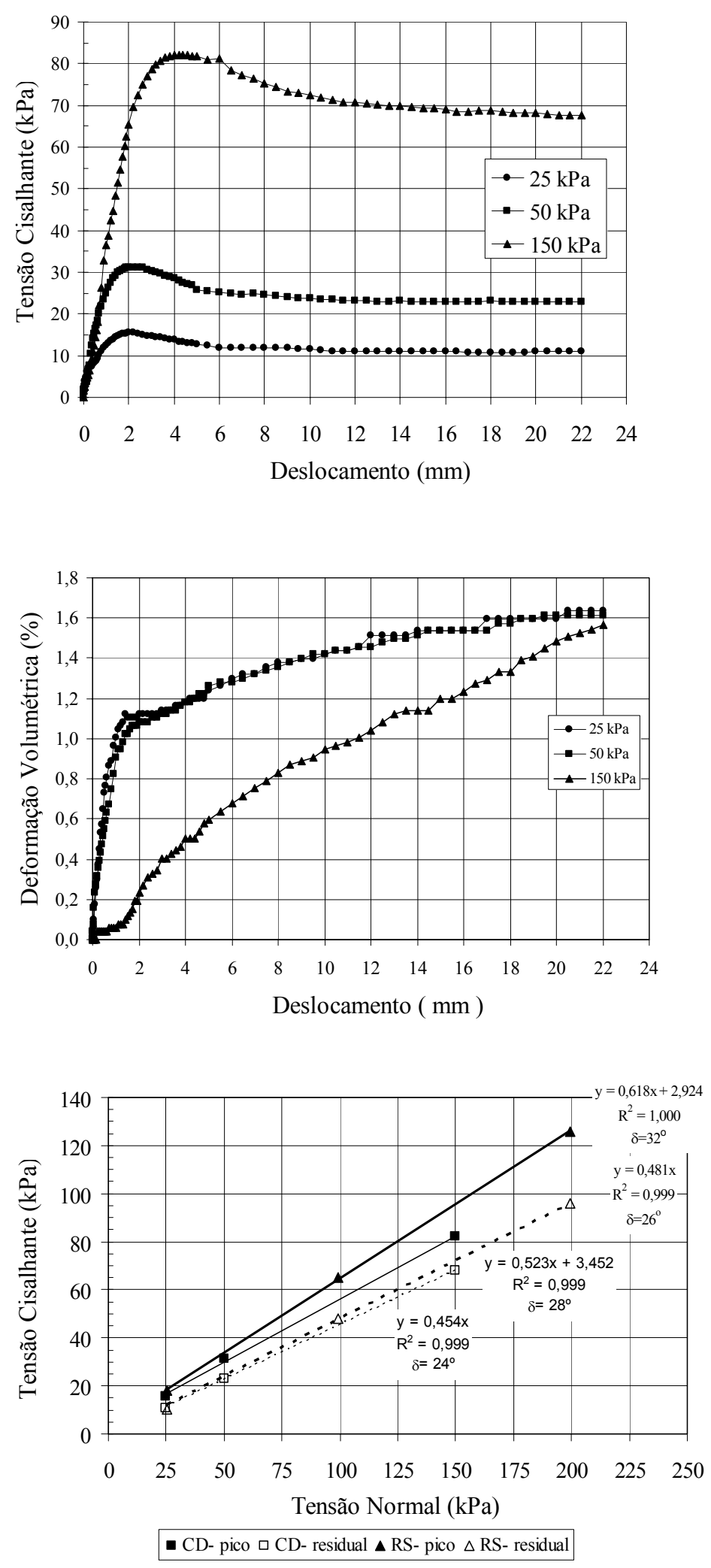

Figura 4.3.5.3. Resultados dos ensaios de interface argila/PEAD AR- solo na umidade ótima/ inundado- Cisalhamento Direto. 
Na Tabela 4.3.5.1 é apresentado um sumário dos resultados de cisalhamento direto e ring shear das interfaces anteriormente apresentadas.

Tabela 4.3.5.1. Comparação entre os ensaios de cisalhamento direto e ring shear.

\begin{tabular}{|c|c|c|c|c|c|c|c|c|}
\hline \multirow[b]{2}{*}{ Interface } & \multicolumn{4}{|c|}{ Cisalhamento Direto } & \multicolumn{4}{|c|}{ Ring shear } \\
\hline & $\begin{array}{c}\mathrm{Cp}_{\mathrm{p}} \\
(\mathrm{kPa})\end{array}$ & $\begin{array}{l}\delta_{p} \\
\text { (०) }\end{array}$ & $\begin{array}{c}\mathrm{Cr} \\
(\mathrm{kPa})\end{array}$ & $\begin{array}{c}\delta_{r} \\
(\circ)\end{array}$ & $\begin{array}{c}\mathrm{Cp}_{\mathrm{p}} \\
(\mathrm{kPa})\end{array}$ & $\begin{array}{l}\delta p \\
(\circ)\end{array}$ & $\begin{array}{c}\mathrm{Cr} \\
(\mathrm{kPa})\end{array}$ & $\begin{array}{c}\delta_{r} \\
\text { (०) }\end{array}$ \\
\hline PEAD lisa- inundado & 2,4 & $\begin{array}{c}19 \\
(0,59)\end{array}$ & - & $\begin{array}{c}11 \\
(0,34)\end{array}$ & - & $\begin{array}{c}16 \\
(0,50)\end{array}$ & - & $\begin{array}{c}8 \\
(0,23)\end{array}$ \\
\hline PEAD AR- não inundado & 7,9 & $\begin{array}{c}29 \\
(0,90)\end{array}$ & - & $\begin{array}{c}23 \\
(0,72)\end{array}$ & 11 & $\begin{array}{c}36 \\
(0,92)\end{array}$ & 2,8 & $\begin{array}{c}28 \\
(0,72)\end{array}$ \\
\hline PEAD AR- inundado & 3,5 & $\begin{array}{c}28 \\
(0,88)\end{array}$ & - & $\begin{array}{c}24 \\
(0,75)\end{array}$ & 2,9 & $\begin{array}{c}32 \\
(1,0)\end{array}$ & - & $\begin{array}{c}26 \\
(0,81)\end{array}$ \\
\hline
\end{tabular}

Com base na tabela acima, verificou-se que o ensaio de ring shear proporciona parâmetros de resistência de interface coerentes com os resultados obtidos pelos ensaios de cisalhamento direto. As diferenças encontradas nos ângulos de atrito podem estar relacionadas a alguns fatores como, por exemplo, condições de fronteira de cada equipamento e superfície da geomembrana utilizada. A propósito, cumpre ressaltar que os ensaios de cisalhamento direto com PEAD AR foram realizados com a superfície menos rugosa da geomembrana.

Ainda com relação aos ensaios de cisalhamento direto, ressalta-se que foi utilizada uma convenção de sinais diferente da empregada no ensaio de ring shear. Enquanto no ring shear, a compressão volumétrica é convencionada como negativa, no ensaio de cisalhamento direto a compressão volumétrica é indicada com sinal positivo. 


\section{CONCLUSÕES}

\subsection{Ensaios de Resistência de Interface com Material Granular}

Com base nos resultados obtidos, pôde-se concluir que o comportamento de resistência ao cisalhamento em interfaces envolvendo geomembranas e materiais granulares depende de uma série de fatores que atuam conjuntamente dentro de um sistema de impermeabilização.

Verificou-se que a curva tensão cisalhante versus deslocamento apresenta um comportamento que depende das características da geomembrana, como flexibilidade e textura. Por exemplo, nas membranas de PEAD lisas, a resistência de pico é mobilizada para pequenos deslocamentos, da ordem de 1,0 mm, ocorrendo uma acentuada queda pós-pico. Nas membranas de PVC, o pico é atingido para maiores deslocamentos e a queda pós-pico é menos pronunciada.

Nos materiais mais flexíveis, como PVC, foram observados elevados valores de atrito de pico $\left(30^{\circ}\right.$ a $\left.33^{\circ}\right)$ e residual $\left(28^{\circ}\right.$ a $\left.29^{\circ}\right)$ de acordo com a compacidade da areia. Em materiais mais rígidos, como PEAD e PELMD, foram verificados baixos valores de ângulos de atrito comparados ao PVC. Para as interfaces com PEAD foram obtidos ângulos de atrito de pico iguais a $17^{\circ}$, para todos os estados de compacidade, e ângulos residuais variando entre $13^{\circ} \mathrm{e}$ $15^{\circ}$. Por sua vez, nas interfaces com geomembranas de PELMD, foram obtidos ângulos entre $17^{\circ}$ e $20^{\circ}$, para a condição de pico, e entre $15^{\circ}$ e $17^{\circ}$ para a condição residual.

Com relação à textura das geomembranas notou-se que ela influenciou as propriedades de atrito, como esperado. Devido a esta característica, as tensões cisalhantes de pico e residual foram mobilizadas para deslocamentos maiores do que nas geomembranas lisas, além do que, a queda pós-pico foi 
menor. Nas geomembranas texturizadas de PEAD-A, foram obtidos valores de atrito de pico entre $26^{\circ}$ a $28^{\circ}$. Quanto aos valores residuais, foram obtidos ângulos entre $23^{\circ}$ a $25^{\circ}$. Constatou-se que a superfície texturizada contribuiu para um aumento de aproximadamente $50 \%$ nos ângulos de atrito de pico e residual em relação às de PEAD lisas. O mesmo comportamento foi verificado nas geomembranas de PEAD-AR, notando-se um aumento de ângulo de atrito de $80 \%$. Nestas, os valores de ângulo de atrito de pico se situaram entre $31^{\circ}$ e $33^{\circ}$ e os ângulos residuais entre $27^{\circ}$ e $30^{\circ}$.

Observou-se ainda que o efeito da compacidade dos materiais granulares mostrou-se pouco acentuado na resistência de interfaces, e que a saturação dos materiais envolvidos propiciou uma ligeira variação nos ângulos de atrito de pico e residual.

\subsection{Ensaios de Resistência de Interface com Solo Argiloso}

À semelhança das areias, constatou-se que nas geomembranas de PVC, que são mais flexíveis, a tensão cisalhante de pico é mobilizada com deslocamentos maiores do que observados nas geomembranas de PEAD (mais rígidas), notando-se também maiores perdas de resistência pós-pico na geomembrana mais rígida.

Quanto à textura das geomembranas, constatou-se que nas geomembranas texturizadas as tensões cisalhantes de pico e residual são mobilizadas para deslocamentos maiores do que constatado nas geomembranas lisas. Averiguou-se que a textura das geomembranas influencia significativamente no comportamento de interfaces com solos argilosos, fornecendo elevados valores de ângulos de atrito de pico e residual.

Em todas as interfaces analisadas, verificou-se que a inundação interfere no comportamento de resistência de interface, resultando na redução dos ângulos de atrito de pico e residual. Quanto à influência da umidade de compactação, pôde-se averiguar que este efeito foi mais notável nos ensaios não inundados.

Quanto à compacidade, averiguou-se que, nos ensaios inundados, os ângulos de atrito obtidos para material moldado com GC de $98 \%$ foram 
maiores do que com GC de 85\%. Ao contrário do que se esperava, nos ensaios não inundados foram observados maiores ângulos de atrito para material moldado com GC de $85 \%$, o que implica em certa reserva quanto a estes valores.

\subsection{Ensaio de Ring Shear}

Através dos resultados aqui apresentados foram obtidos alguns parâmetros de resistência de interface envolvendo geomembranas e solos utilizados em barreiras impermeáveis, obtidos por meio do ensaio de ring shear. Além da obtenção destes parâmetros, pôde-se investigar alguns aspectos que influenciam no comportamento em interfaces, tais como tipo e textura da geomembrana, condições de compactação do solo e saturação.

Esta nova alternativa de ensaio para o estudo de resistência de interfaces mostrou algumas diferenças de resultados em relação aos resultados dos ensaios de cisalhamento direto, principalmente, nos ensaios com solo. Essas diferenças podem ser creditadas às condições próprias de cada ensaio e respectivo equipamento e às velocidades empregadas. Contudo, verificou-se que o ensaio de ring shear proporciona parâmetros de resistência de interface coerentes com os sugeridos na literatura e com os parâmetros obtidos pelos ensaios de cisalhamento direto que foram realizados neste trabalho, o que o torna uma atraente opção para tais estudos.

\subsection{Sugestões para futuros trabalhos}

- Utilização de outros solos, como argilas com elevado índice de plasticidade; 
- Realização de ensaios com variações no grau de compacidade, de forma a investigar detalhadamente os resultados aqui encontrados;

- Verificação do efeito da consolidação da argila na resistência de interface, através da realização de ensaios não consolidados;

- Realização de ensaios de ring shear em condição drenada para interfaces com argila;

- Estudar alguns agentes de degradação na resistência de interface como, por exemplo, temperatura e ação de líquidos percolados. 


\section{REFERÊNCIAS BIBLIOGRÁFICAS}

ASSOCIAÇÃO BRASILEIRA DE NORMAS TÉCNICAS (1984)- MB 3324- SoloDeterminação do índice de vazios máximo de solo não coesivo.

. (1984)- MB 3388- Solo-Determinação do índice de vazios mínimo de solo não coesivo.

. (1984)- NBR 6459-Solo-Determinação do limite de liquidez.

.(1984)- NBR 6508- Grãos de solos que passam na peneira de 4,8mm- Determinação da massa específica.

.(1984)- NBR 7181-Solo-Análise Granulométrica.

. (1984)- NBR 7182- Solo-Ensaio de compactação.

.(1987)- NBR 8419- Apresentação de projetos de aterros sanitários de resíduos sólidos urbanos.

. (1984)- NBR 9180- Solo-Determinação do limite plasticidade.

.(1987)- NBR 10.004- Resíduos sólidos.

ASTM D297- Standard Test Method for Rubber Products- Chemical Analysis.

ASTM D638- Standard Test Method for Tensile Properties of Plastics.

ASTM D648- Standard Test Method for Deflection Temperature of Plastics under Flexural Load in the Edgewise Position.

ASTM D696- Standard Test Method for Coefficient of Linear Thermal Expansion of Plastics Between $-30^{\circ} \mathrm{C}$ and $30^{\circ} \mathrm{C}$ with a Vitreous Silica Dilatometer.

ASTM D792- Standard Test Method for Specific Gravity and Density of Plastics by Displacement. 
ASTM D822- Standard Test Method Tensile Properties of Thin Plastics Sheeting.

ASTM D1004- Standard Test Method for Initial Tear Resistance of Plastic Film and Sheeting.

ASTM D1204- Standard Test Method for Lineal Dimensional Changes of Non

- Thermoplastic Sheeting or Film at Elevated Temperature.

ASTM D1505- Standard Test Method for Density of Plastics by the DensityGradient Technique.

ASTM D1593- Standard Specification for Non-rigid Vinychloride Plastic Sheeting.

ASTM D1603- Standard Test Methods for Carbon Black in Olefin Plastics.

ASTM D1790- Standard Test Method for Brittleness Temperature of Plastic Sheeting by Impact.

ASTM D2136- Standard Test Method for Coated Fabrics - Low- Temperature Bend Test.

ASTM D2240- Standard Test Method for Rubber Property - Durometer Hardness.

ASTM D3015- Standard Recommended Practice for Microscopical Examination of Pigment Dispersion in Plastic Compounds.

ASTM D3417- Standard Test Method for Heats of Fusion and Crystallization of Polymers by Thermal Analysis.

ASTM D3418- Standard Test Method for Transition Temperatures of Polymers by Thermal Analyses.

ASTM D3767- Standard Practice for Rubber-Measurement of Dimensions.

ASTM D3776- Standard Test Method for Weight (Mass per Unit Area) of Woven Fabric.

ASTM D3786- Standard Test Method for Hydraulic Bursting Strength of Textiles Fabrics - Diaphragm Bursting Strength Test Method.

ASTM D4437- Standard Practice for Determining the Integrity of Field Seams Used in Joining Flexible Polymeric Sheet Geomembranes.

ASTM D4545- Standard Practice for Determining the Integrity of Factory Seams Used in Joining Manufactured Flexible Sheet Geomembranes. 
ASTM D4833- Standard Test Method for Index Puncture Resistance of Geotextiles, Geomembranes, and Relatex Products.

ASTM 5199- Standard Test Method for Measuring the Nominal Thickness of Geosynthetics.

ASTM D5261- Standard Test Method for Measuring mass per Unit Area of Geotextiles.

ASTM D5262- Standard Test Method for Evaluation the Unconfined Tension Creep Behavior of Geosynthetics.

ASTM D5321- Standard Test Method for Determining the Coefficient of Soil and Geosynthetic or Geosynthetic Friction by the Direct Shear Method.

ASTM D5397- Standard Test Method for Evaluation of Stress Crack Resistance of Polyolefin Geomembranes Using Notched Tensile Load Test.

ASTM D5596- Standard Test Method for Microscopic Evaluation of the Dispersion of Carbon Black in Polyolefin Geossynthetics.

ASTM D5617- Standard Test Method for Multiaxial Tension Test for Geosynthetics.

ASTM D6370- Standard Test Method for Rubber- Compositional Analysis by Thermogravimetric (TGA).

ASTM E28- Standard Test Method for Softening Point of Resins Derived from Naval Stores by Ring - and Ball Apparatus.

ASTM E96- Standard Test Method for Water Vapor Transmission of Materials.

ASTM E831- Standard Test Method for Linear Thermal Expansion of Solid Materials by Thermomechanical Analysis.

ASTM E2105- Standard Practice for general Techniques of Thermogravimetric Analysis (TGA/IR).

BAGCHI, A. (1994)- Design, construction and monitoring of sanitary landfillJohn Wiley \& Sons- New York- 2a ed. -361p.

BOUAZZA, A. (1996)- "Evaluation of the soil-PVC geomembrane interface friction for landfill design"- Geosynthetics: applications, design and construction - De Groot, Den Hoedt \& Termaat (eds.)- pp. 189 - 192.

BOUAZZA, A.; ZORNBERG, J.G.; ADAM, D. (2002)- "Geosynthetics in waste containment facilities: recent advances"- Geosynthetics - $7^{\text {th }}$ ICG Delmas, Gourc \& Girard (eds.)- Nice - França. 
BROMHEAD, E.N. (1979)- "A simple ring shear apparatus"- Ground Engineering, 12 (5): 40-44.

CARVALHO, M. F. (1999)- "Comportamento mecânico de resíduos sólidos urbanos"- Tese de doutorado - EESC - USP- 278p.

DANIEL, D.E. (1993)- Geotechnical practice for waste disposal- London ; New York- Chapman \& Hall - 683p.

DEN HOEDT, G. (1988)- "Durability experience in the Netherlands, 19581988"- Durability and agning of geosynthetics- R. Koerner -editor- p.82-94.

ESTERHWIZEN, J.; FILZ, G. M.; DUNCAN, J. M. (2001)- "Constitutive behavior de geosynthetics interfaces"- Journal of Geotechnical and Geoenvironmental Engineering - vol. 127, n 10 , pp. 1-7

FARRAG, K., ACAR Y.B. \& JURAN I. (1993)- "Pull-Out Resistance of Geogrid Reinforcements"- Geotextiles and Geomembranes- 12: 3, pp.133-159.

FILZ, G.M; ESTERHUIZEN, J.J.B.; DUNCAN, J.M. (2001)- "Progressive failure of lined waste impoudments"- Journal of Geotechnical and Geoenvironmental-127-n० 10- pp.1-8.

FISHMAN, K.L.; PAL, S. (1994)- "Further study of geomembrane/cohesive soil interface shear behavior"- Geotextiles and geomembranes 13- pp. 571-590.

GARTUNG, E. (1996)- "Landfill liners and covers"- Geosynthetics: applications, design and construction- De Groot, Den Hoedt \& Termaat (eds.)- pp. 55 - 70.

GILBERT ET AL. (1996) APUD FILZ ET AL. (2001)- "Progressive failure of lined waste impoudments"- Journal of Geotechnical and Geoenvironmental127-n० 10- pp.1-8.

GIROUD, J.P.; DARRASSE, J. (1993)- "Hyperbolic expression for soil geosynthetic or geosynthetic - geosynthetic interface shear strength"Geotextiles and geomembranes - 12- pp. 275-286.

GÓMEZ, J.E.; FILZ, G.M.- "Effects of consolidation on the strength of the interface between a clay liner and a smooth geomembrane"Geosynthetics 99.-pp.681-696.

HEAD, K.H. (1994)- "Manual of soil testing: permeability, shear strength and compressibility tests"- vol.2- $2^{\text {nd }}$ edition-440pp.

HEDERRA,R.(1996)- Manual de vigilância sanitária- 144p.-Washington: OPAS. 
HSIEH, C.; HSIEH, M.H.; CHEN,J. (2002)- "Direct shear behavior of sand geomembrane systems for various shear boxes"- Geosynthetics- $7^{\text {th }}$ ICGDelmas, Gourc \& Girard (eds.)- Nice- França.

INGOLD, T.S. (1990)- "Friction testing"- Geomembranes: identification and perfomance testing-edited by A. Rollin and J.M. Rigo.

IZGIN, M.; WASTI, V. (1998)- "Geomembrane-sand interface frictional properties as determined by inclined board and shear box tests"Geotextiles and geomembranes 16 - pp.207-219.

JOHN,N.W.M. (1987)- "Geotextiles"- Chapman and Hall- 347p.

JONES, D.R.V.; DIXON, N. (1998)- "Shear strength properties of geomembrane / geotextiles interfaces"- Geotextiles and geomembranes - vol. $16-n^{\circ} .1-p p .45-71$.

KOERNER, R.; SOONG, T.Y. (1998)- "Analysis and design of veneer cover soils"- Sixth International Conference on Geosynthetics-March 1998Atlanta, Georgia- USA-pp.1-23.

KOERNER, R.M. (1994)- Design with geosynthetics- $3^{\text {rd }}$ Edition- Prentice Hall.

LEE, S.W.; FROST, J.D.; RIGHTER, G.K. (1998)- "The influence of geomembrane surface roughness on geomembrane - geotextile interface strength"- Sixth International Conference on Geosynthetics- AtlantaGeorgia- USA-pp 433-438.

LEITE, W.C.A. (1991)- "Estudo do comportamento da temperatura, pH e teor de umidade na decomposição de resíduos sólidos urbanos em aterros sanitários"- Tese de mestrado- EESC/USP.

LENGEN, A.; SIEBKEN, J. (1996)- "Geomembrane in the United States: A brief discussion"- Geosynthetics: applications, design and constructionDe Groot, Den Hoedt \& Termaat (eds.)- pp. 697- 704.

MANUAL DE GERENCIAMENTO INTEGRADO DO LIXO MUNICIPAL (1995)São Paulo- Instituto de Pesquisas Tecnológicas- IPT- 278pág.

MASADA, T. et al. (1994)- "Modified direct shear study of a clay-linergeomembranes interfaces exposed to landfill leachate"- Geotextile and geomembranes 13- pp. 165- 179.

MAURO, C.A. (1997)- "Laudos periciais em depredações ambientais"Laboratório de planejamento municipal- DPR- IGCC - UNESP- pág. 87147.

MITCHELL, J.K. (1993) APUD SHALLENBERG \& FILZ (1996)- "Interface strength determination using a large displacement shear box"- Environmental Geotchnics, Kamon (ed.)- pp. 147-152. 
MITCHELL, J.K.; SEED, R.B.; SEED, B.H. (1990)- "Kettleman Hills waste landfill slope failure I : liner system properties"- Journal of Geotechnical Engineering, vol. 116, n 4 - pp. 647-668.

NEGUSSEY, D.; WIJEWICKREME, W.K.D.; VAID, V.P. (1989)- "Geomembrane interface friction"- Journal of Canadian Geotechnique - vol. 26, pp.165169.

ORMAN, M.E. (1994)- "Interface shear strength properties of roughened HDPE"- Journal of Geotechnical Engineering-vol. 120, n 4-pp. 758 a 761.

O'ROURKE, T.D.; DRUSCHEL, S.J.; NETRAVALI, A.N. (1990)- "Shear strength characteristics of sand-polymer interfaces"- Journal of Geotechnical Engineering - vol. 116, n॰ 4, pp. 451-469.

PALMEIRA, E.M. (1992)- "Geossintéticos: tipos e evolução nos últimos anos"- Seminário sobre aplicações de geossintéticos em Geotecnia Brasília (DF).

PASQUALINI, E.; SANI, D.; ROCCATO, M. (1993)- "Factors influencing geomembrane interface friction"- Proceedings of the Symposium Green 93- Geothecnics related to the environment- Bolton- UK- Jule- edited by R. M. Sarsby.

POHL, D. H.; WESTON, R.F. (1992)- "Geomembranas: aplicações e considerações sobre confiabilidade e controle de qualidade"- Seminário sobre aplicações de geossintéticos em Geotecnia- Geossintéticos'92.Brasília (DF)- pp. 140-163.

ROWE, R.K. (1998)- "Geosynthetics and the minimization of contaminant migration through barrier systems beneath solid waste"- Sixth International Conference on Geosynthetics- March 1998- Atlanta, Georgia- USA-pp.27102.

RUBERG, G. (1999)- "O gerenciamento de resíduos sólidos domiciliares: o caso de João Pessoa"- dissertação de mestrado- 176p.- FAU- São Paulo.

SEED, R.B.; BOULANGER, R.M. (1991)- "Smooth HDPE - clay liner interface shear strengts: compaction effects"- Journal of Geotechnical Engineering, vol. 117, no 4 - pp. 686-693.

SEED, R.B.; MITCHELL, J.K.; SEED, B.H. (1990)- "Kettleman Hills waste landfill slope failure II : stability analyses"- Journal of Geotechnical Engineering, vol. 116, no 4- pp. 668-689.

SHALLENBERGER, W.C.; FILZ, G.M. (1996)- "Interface strength determination using a large displacement shear box"- Environmental Geotchnics, Kamon (ed.)- pp. 147-152. 
SHARMA, H.D.; LEWIS, S.P. (1994)- "Waste containment systems, waste stabilization and landfills: design and evaluation"- New York: J.Wiley- 585p.

STARK, T.; POEPPEL, A.R. (1994)-"Landfill liner interface strengths from torsional - ring- shear tests"- Journal of Geotechnical Engineering- vol. $120-n \circ 3$ - pp. 597-615.

SWAN JR, R.H.; BONAPARTE, R.; BACHUS, R.C. (1991)- "Effect of soil compaction conditions on geomembranes - soil interface strength"Geotextiles and geomembranes- vol.10, pp. 523-529.

TAN, S. A.; CHEW, S.H.; WONG, W. K. (1998)- "Sand- geotextiles interface shear strength by torsional ring shear tests"- Geotextiles and geomembranes 16- pp.161-174.

TIVERON, V.P.M. et al. (1995)- Disposição de resíduos sólidos no município de São Paulo: aterros sanitários. I Seminário Luso-Brasileiro de Geotecnia Ambiental, Lisboa, 15p.

WASTI, Y.; ÖZDÜZGÜN, Z.B. (2001)- "Geomembrane-geotextile interface shear properties as determined by inclined board and direct shear box tests"- Geotextiles and geomembranes vol.19 - pp.45-47.

YEGIAN, M.K; LAHLAF, A.M. (1992)- "Dynamic inteface shear strength properties of geomembranes and geotextiles"- Journal of Geotechnical Engineering, vol.118-n 5-pp. 760-779. 
APÊNDICE A- Resultados dos Ensaios de Tração em Geomembranas.

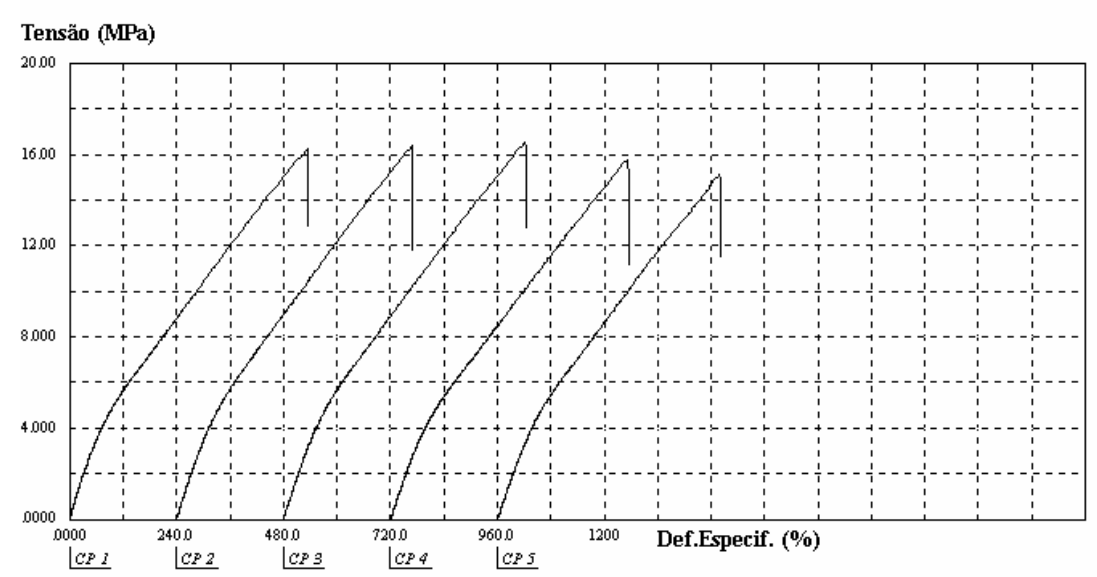

Figura A.1. Resultados dos ensaios de tração/ PVC- sentido longitudinal.

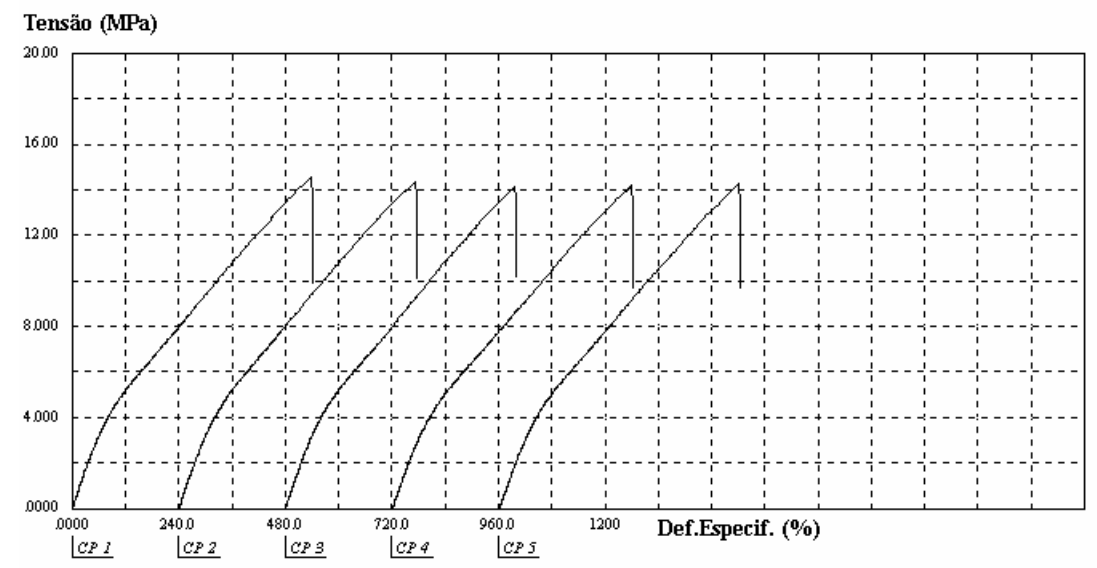

Figura A.2. Resultados dos ensaios de tração/ PVC- sentido transversal.

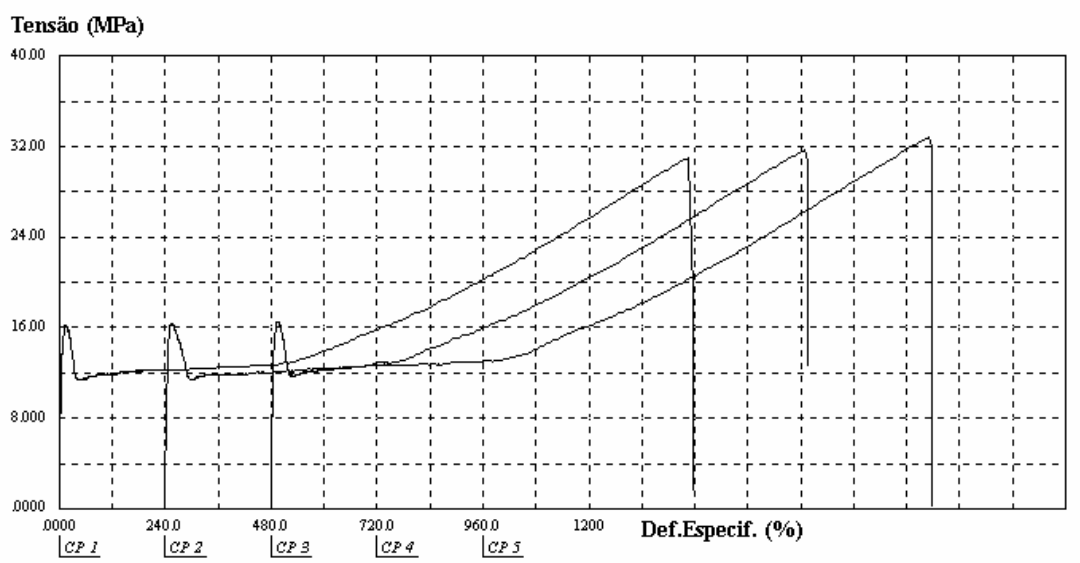

Figura A.3. Resultados dos ensaios de tração/ PEAD lisa- sentido longitudinal. 


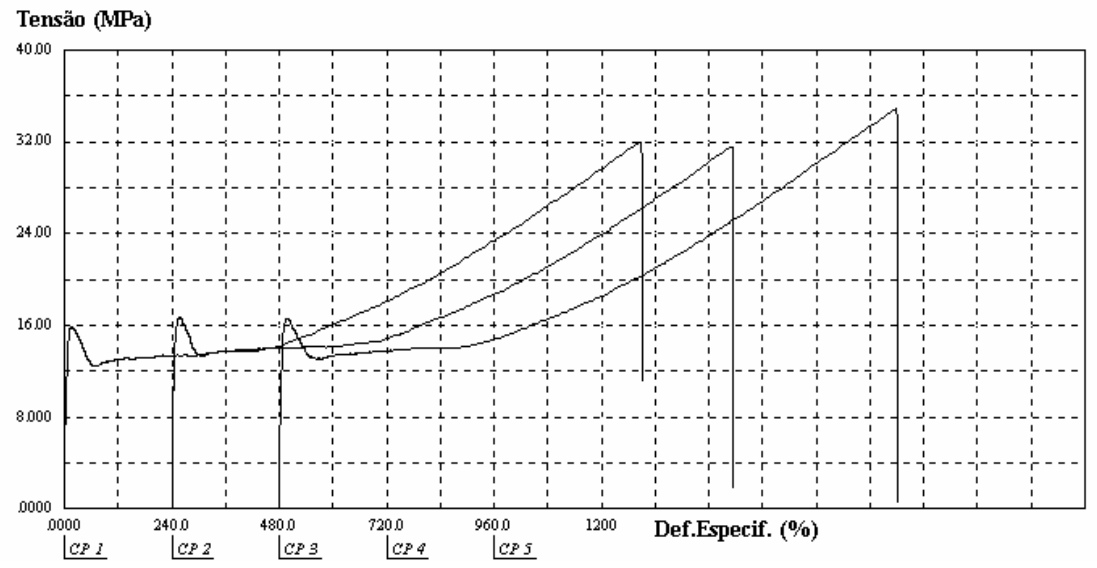

Figura A.4. Resultados dos ensaios de tração/ PEAD lisa- sentido transversal.

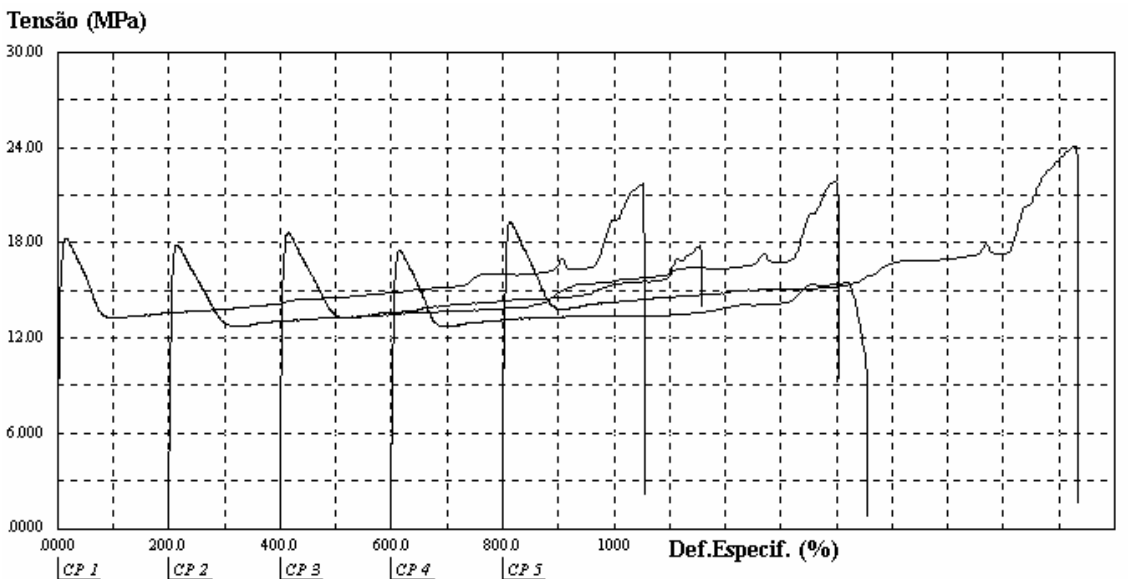

Figura A.5. Resultados dos ensaios de tração/ PE linear- sentido longitudinal.

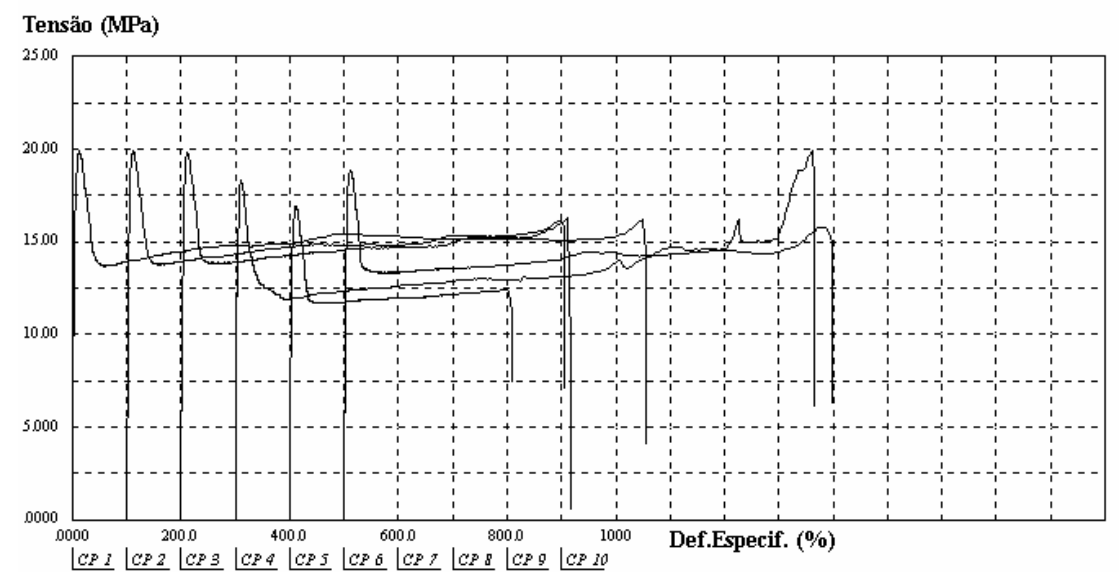

Figura A.6. Resultados dos ensaios de tração/ PE linear- sentido transversal. 


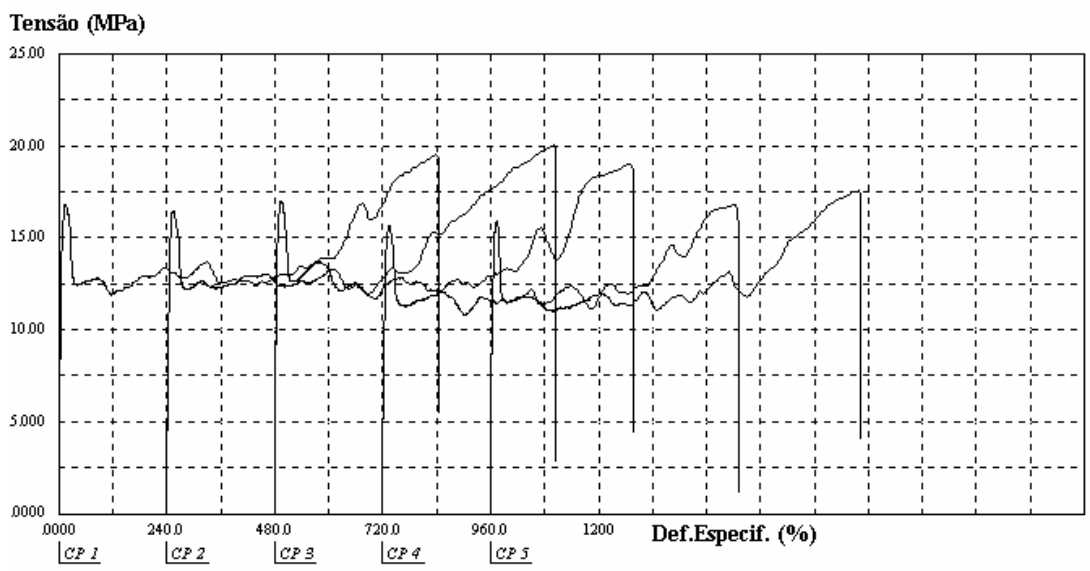

Figura A.7. Resultados dos ensaios de tração/ PEAD A- sentido longitudinal.

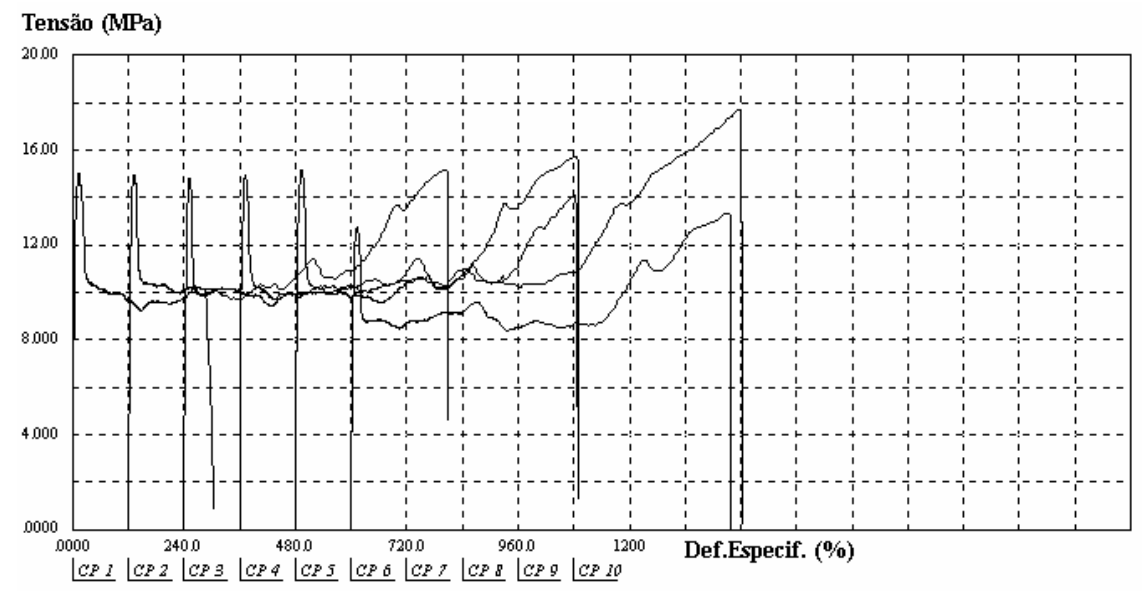

Figura A.8. Resultados dos ensaios de tração/ PEAD A- sentido transversal.

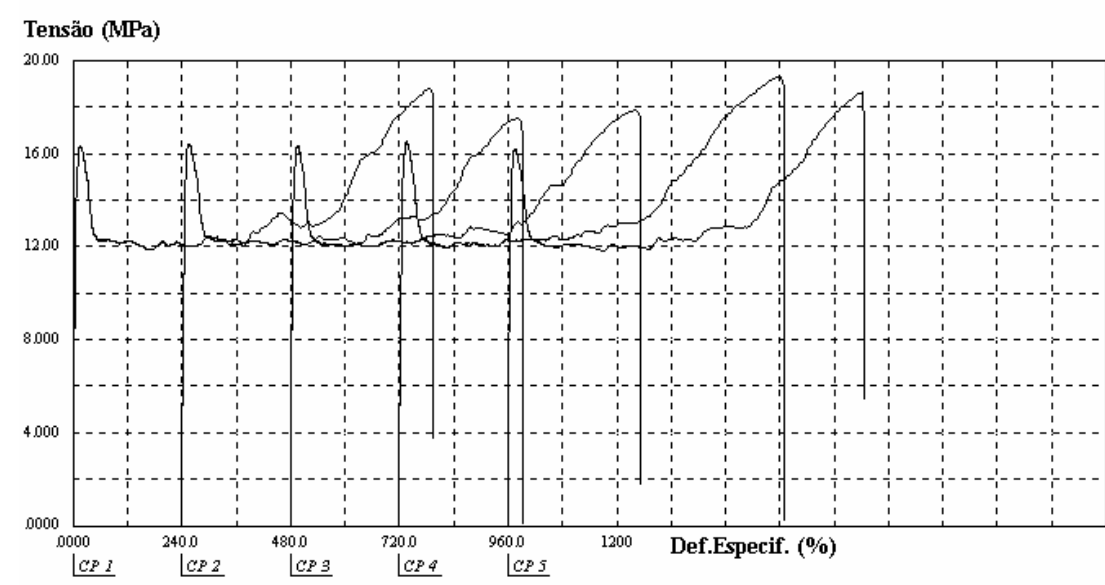

Figura A.9. Resultados dos ensaios de tração/ PEAD AR- sentido longitudinal. 


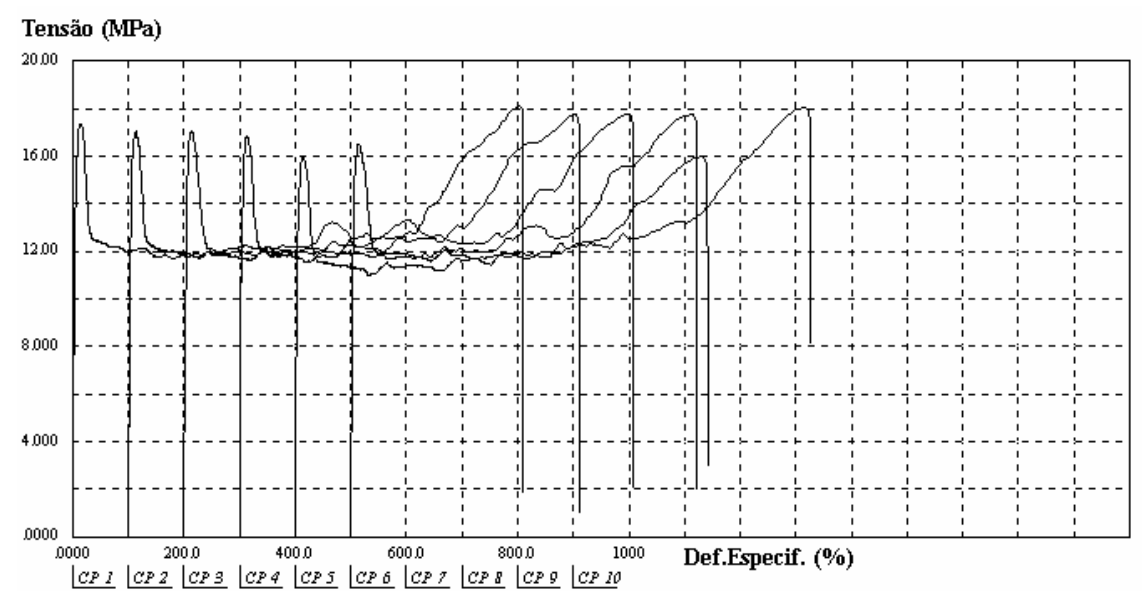

Figura A.10. Resultados dos ensaios de tração/ PEAD AR- sentido transversal. 
APÊNDICE B- Resultados dos Ensaios de Resistência de Interface entre geomembranas e areia- Condição seca.
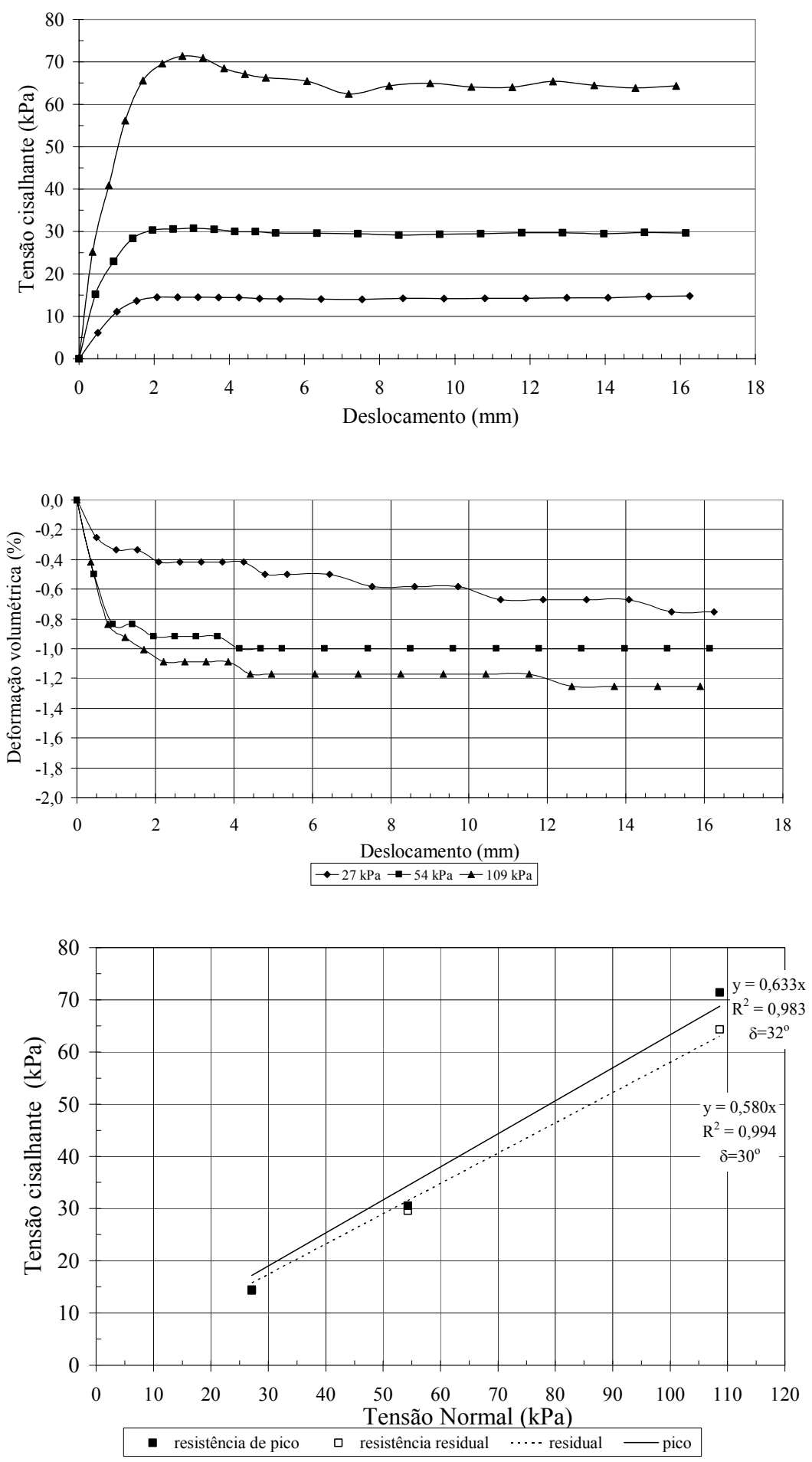

Figura B.1. Resultados dos ensaios de interface PVC/areia-CR $=0 \%-2^{a}$ série. 

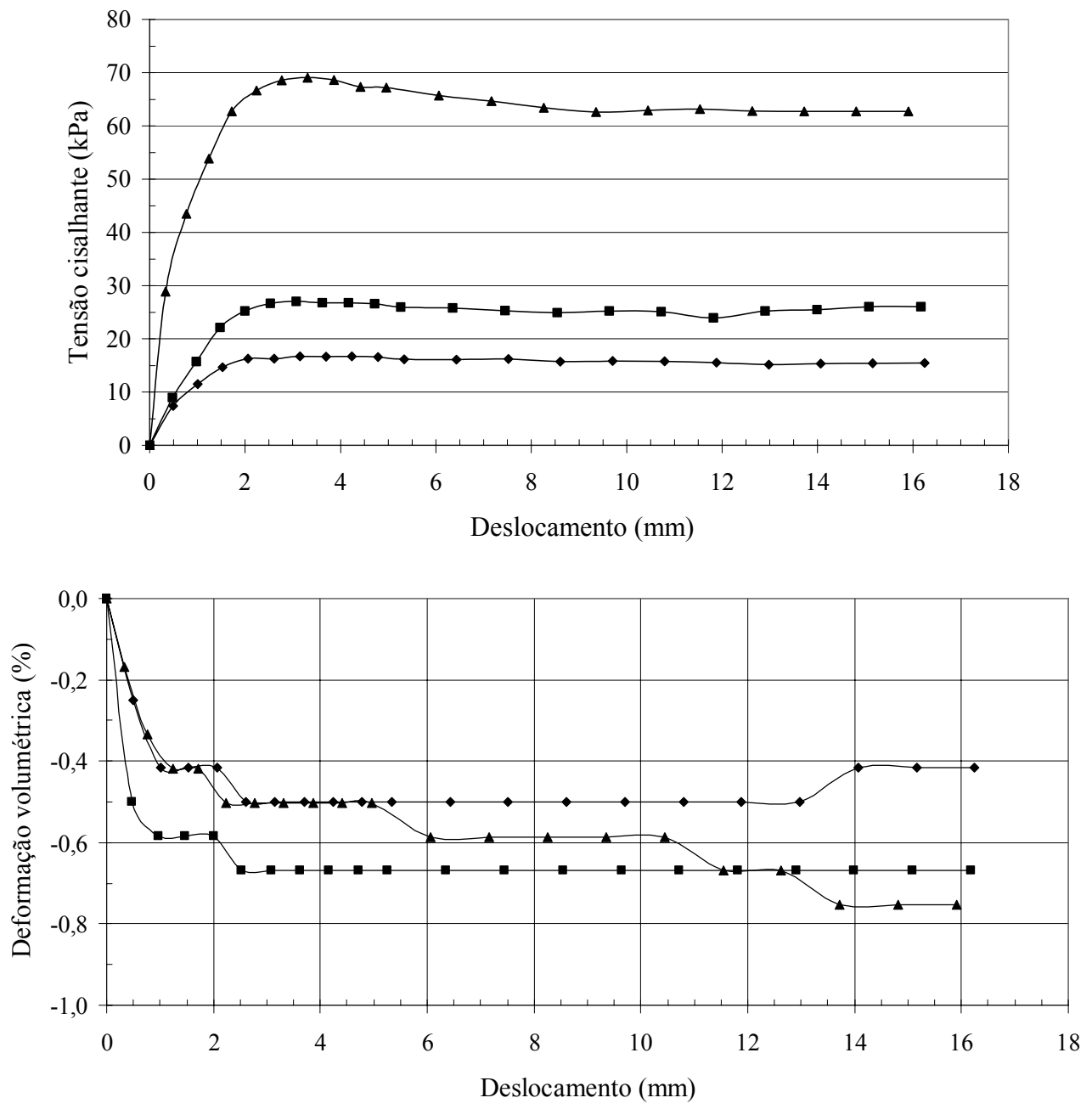

$27 \mathrm{kPa} \rightarrow-54 \mathrm{kPa} \leftarrow 109 \mathrm{kPa}$

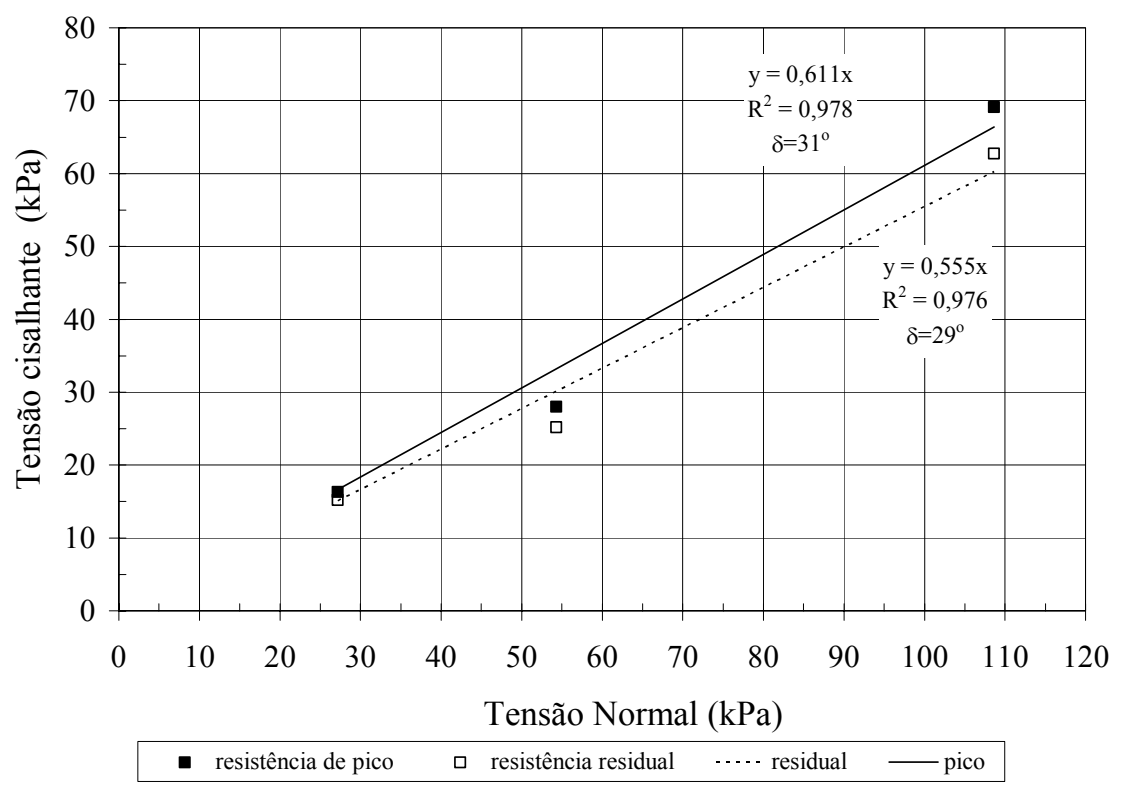

Figura B.2. Resultados dos ensaios de interface PVC/areia-CR=0\%- $3^{a}$ série. 

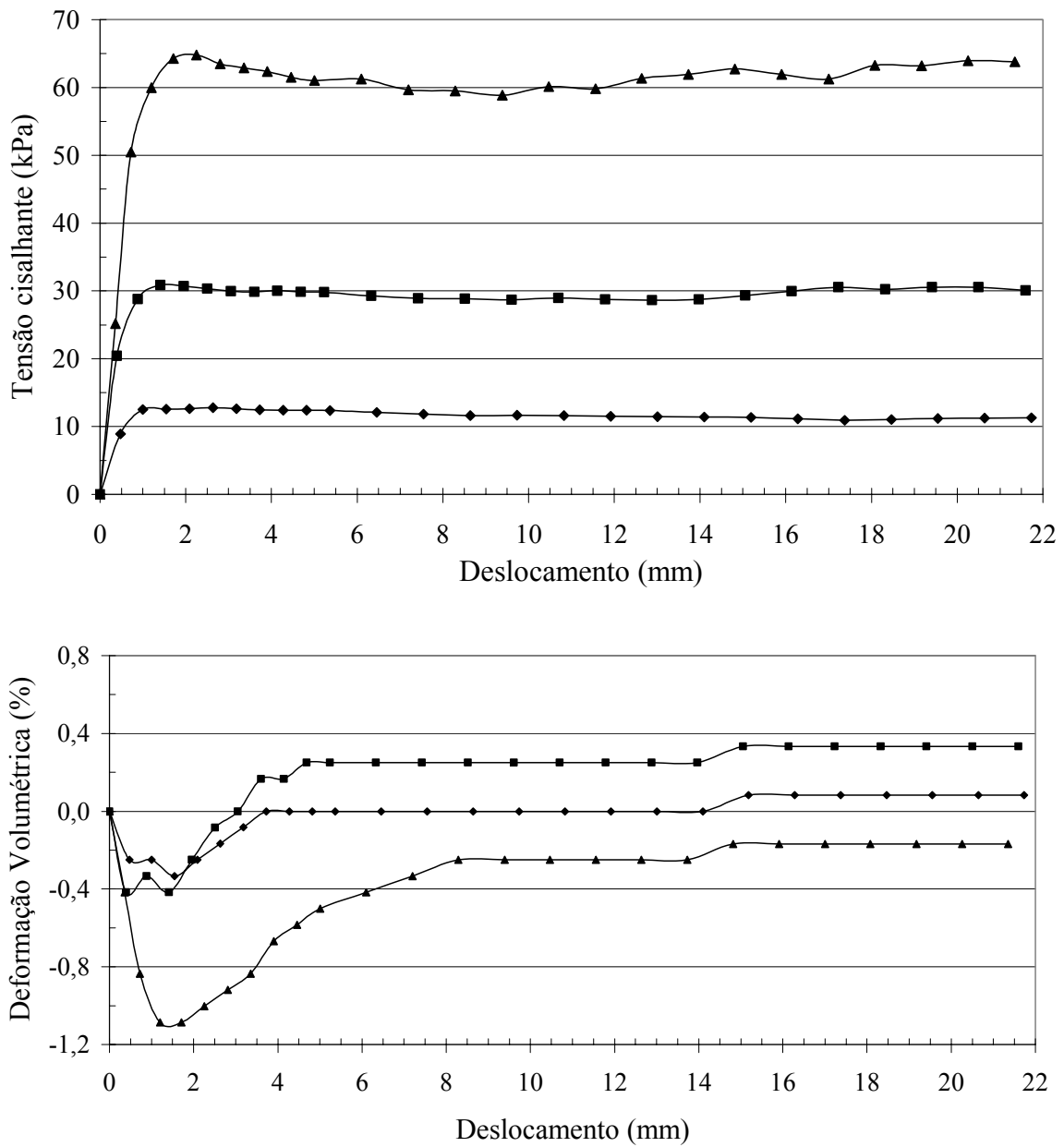

$\rightarrow 27 \mathrm{kPa} \rightarrow-54 \mathrm{kPa} \rightarrow 109 \mathrm{kPa}$

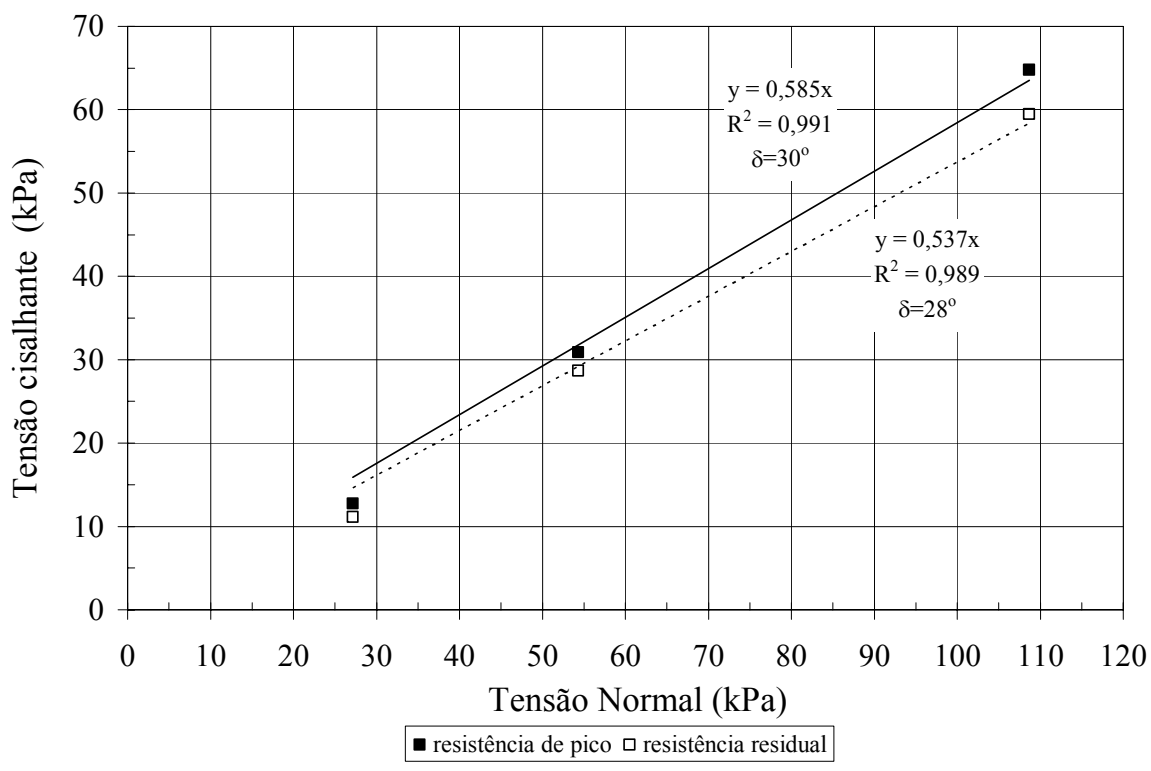

Figura B.3. Resultados dos ensaios de interface PVC/areia-CR=57\%- $2^{a}$ série. 

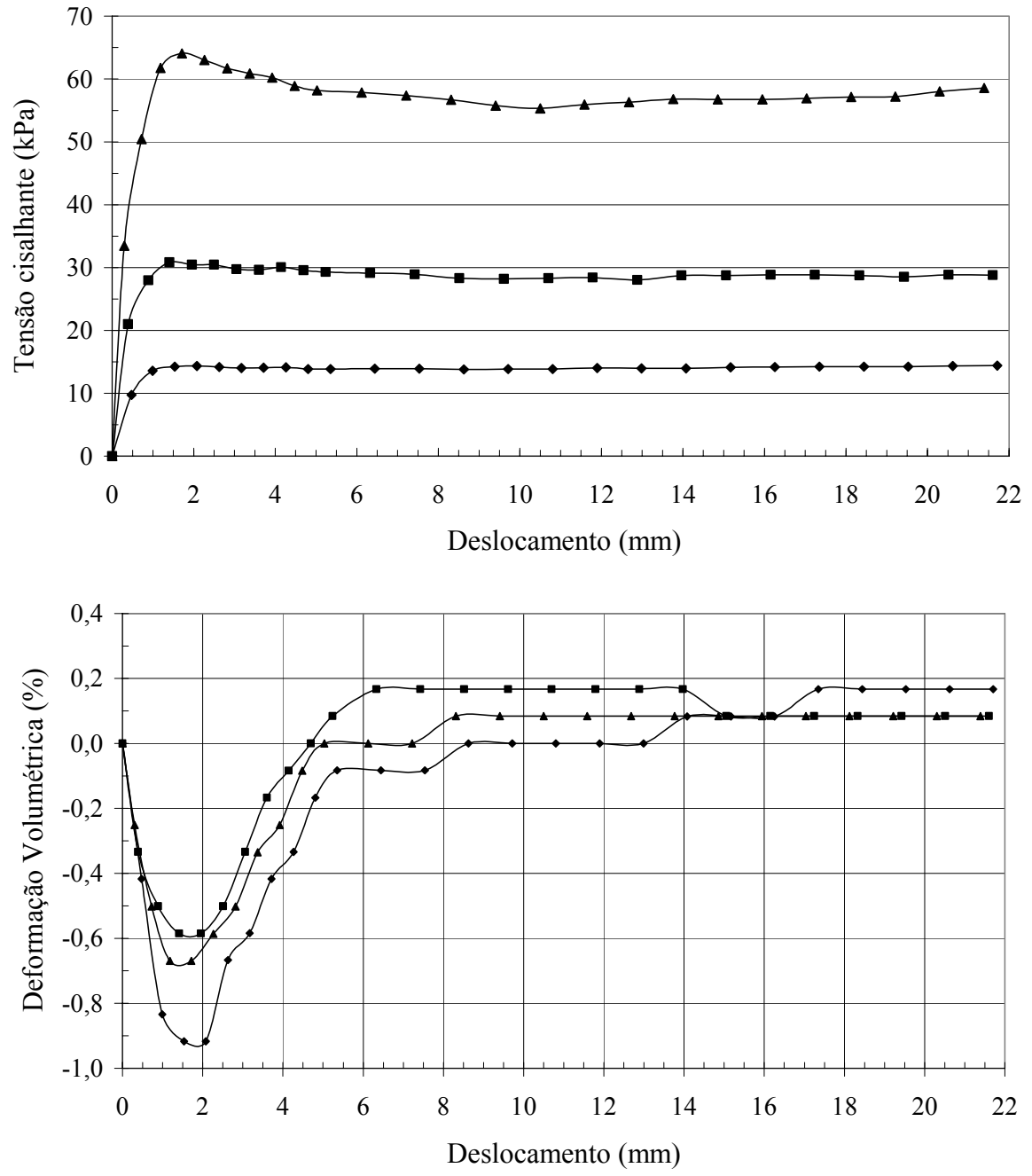

$\rightarrow-27 \mathrm{kPa} \rightarrow-54 \mathrm{kPa} \longrightarrow 109 \mathrm{kPa}$

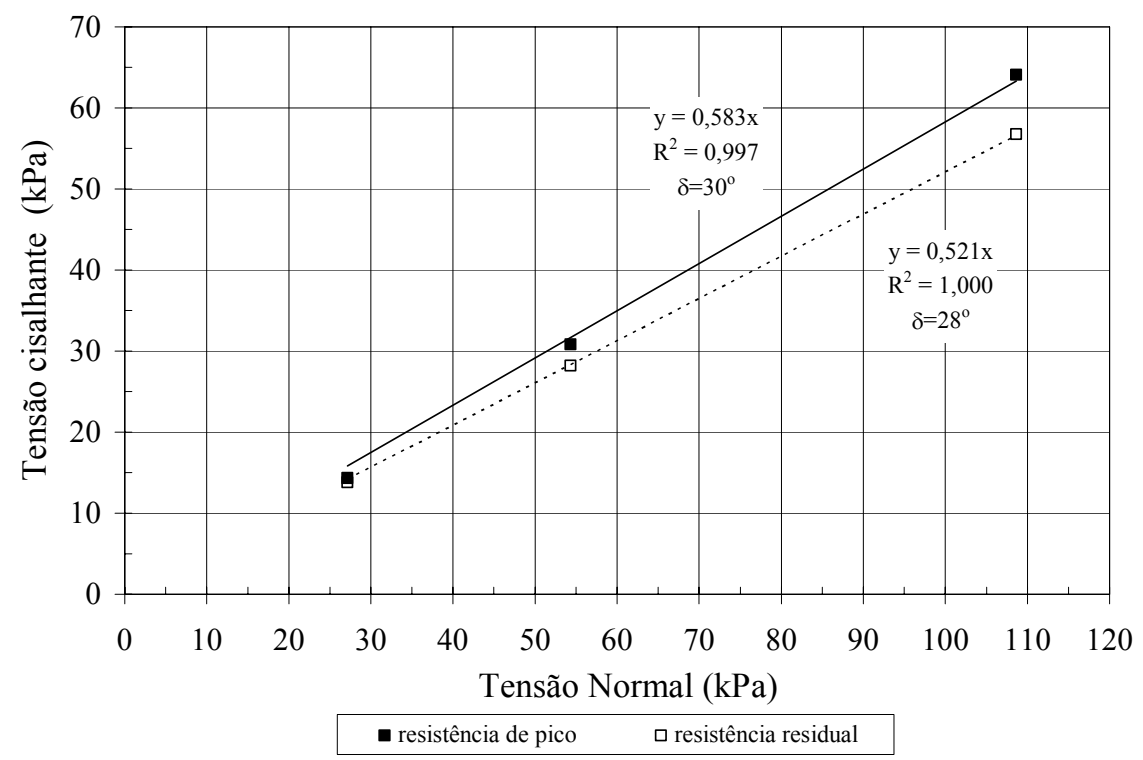

Figura B.4. Resultados dos ensaios de interface PVC/areia-CR=57\%- $3^{a}$ série. 

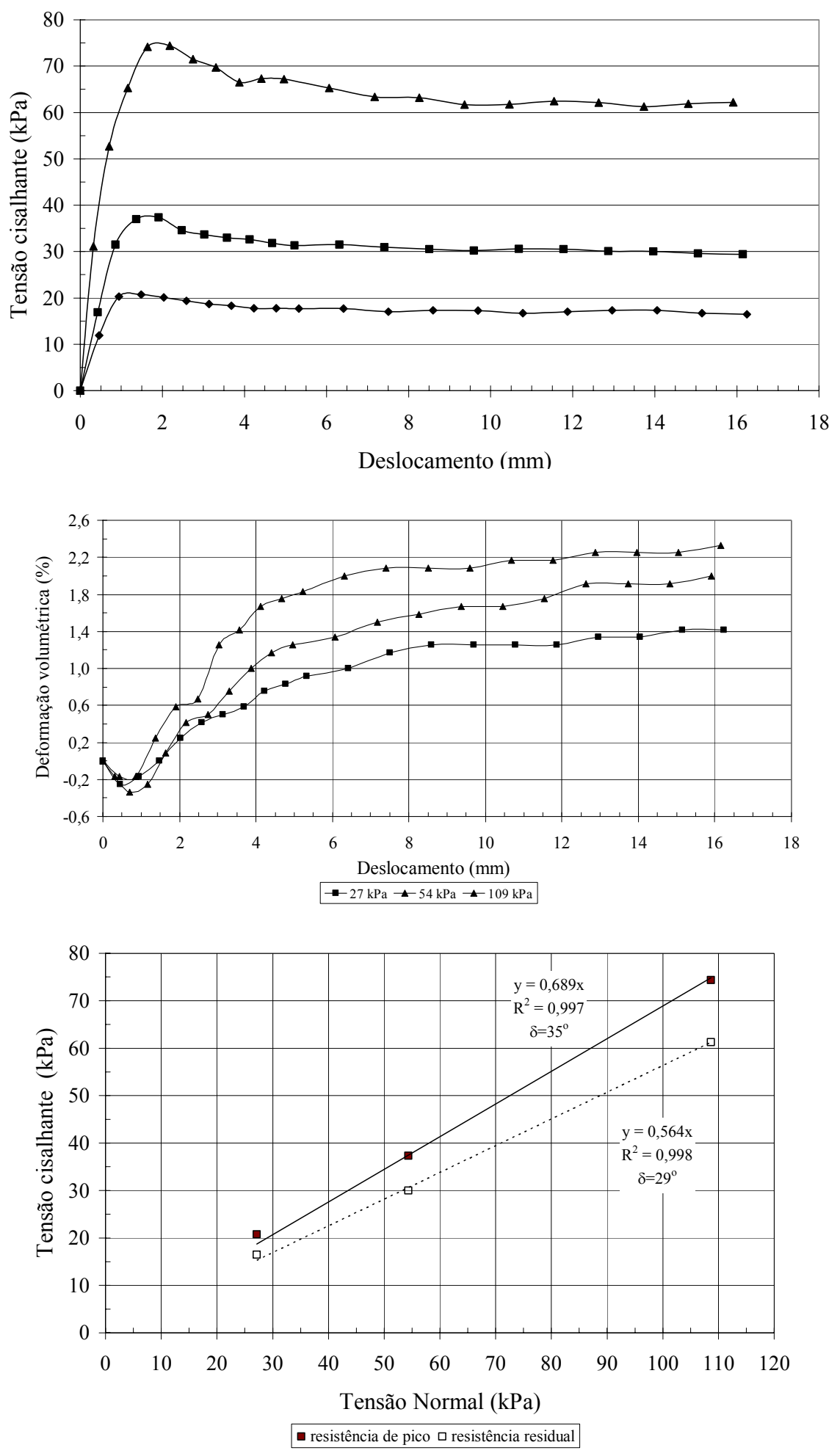

Figura B.5. Resultados dos ensaios de interface PVC/areia-CR=100\%- $2^{a}$ série. 

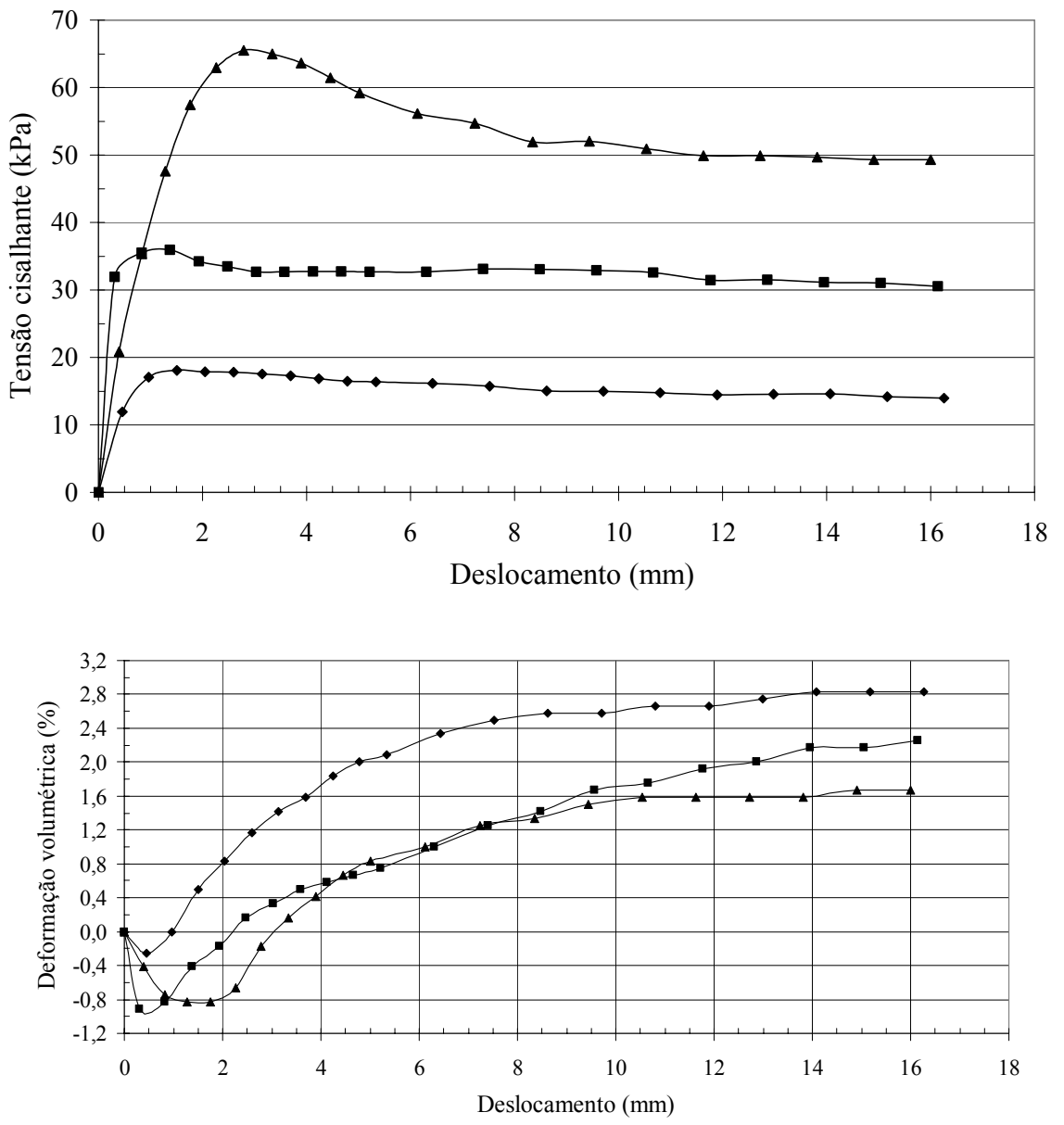

$\multimap-27 \mathrm{kPa}-54 \mathrm{kPa} \neg 109 \mathrm{kPa}$

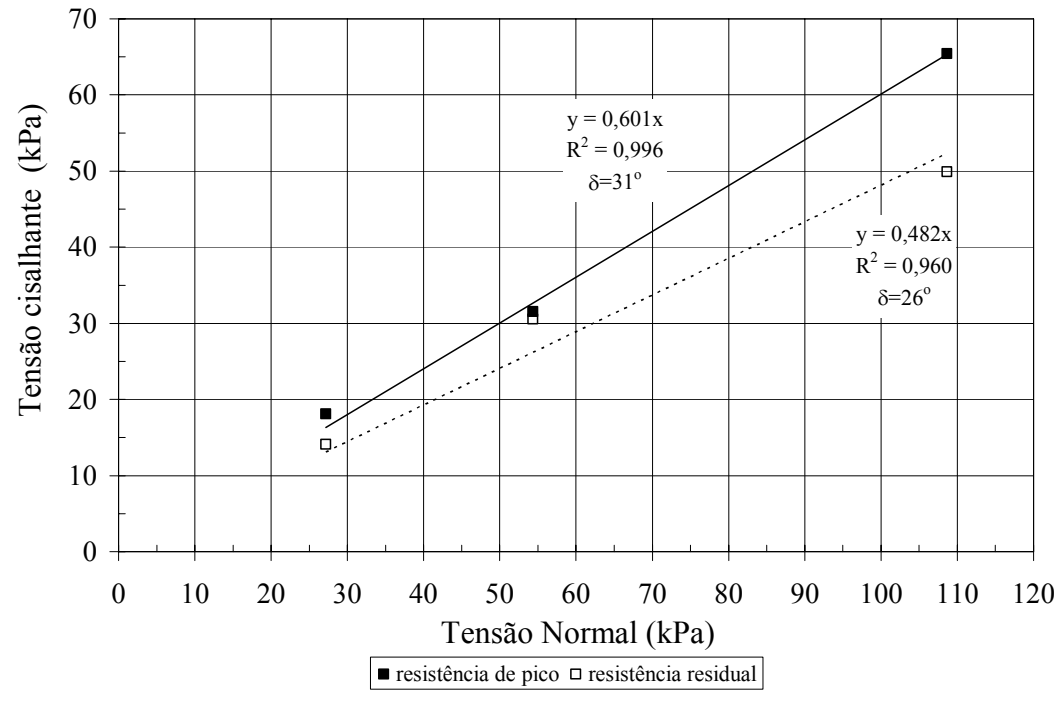

Figura B.6. Resultados dos ensaios de interface PVC/areia-CR=100\%- $3^{a}$ série. 

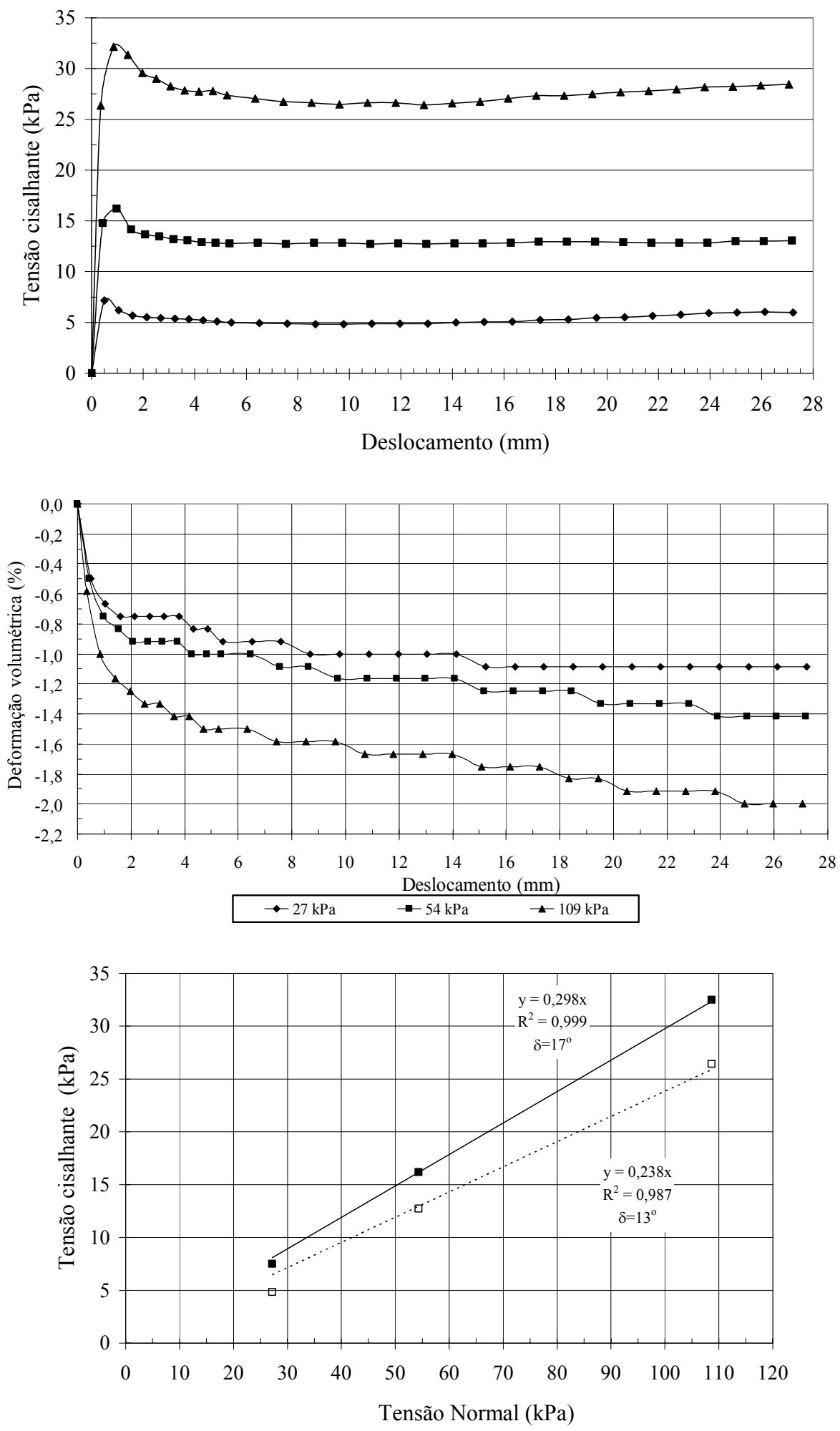

- resistência de pico $\quad \square \quad$ resistência residual $\cdots$ … residual $\square$ pico

Figura B.7. Resultado dos ensaios de interface PEAD/areia-CR=0\%- $2^{a}$ série. 

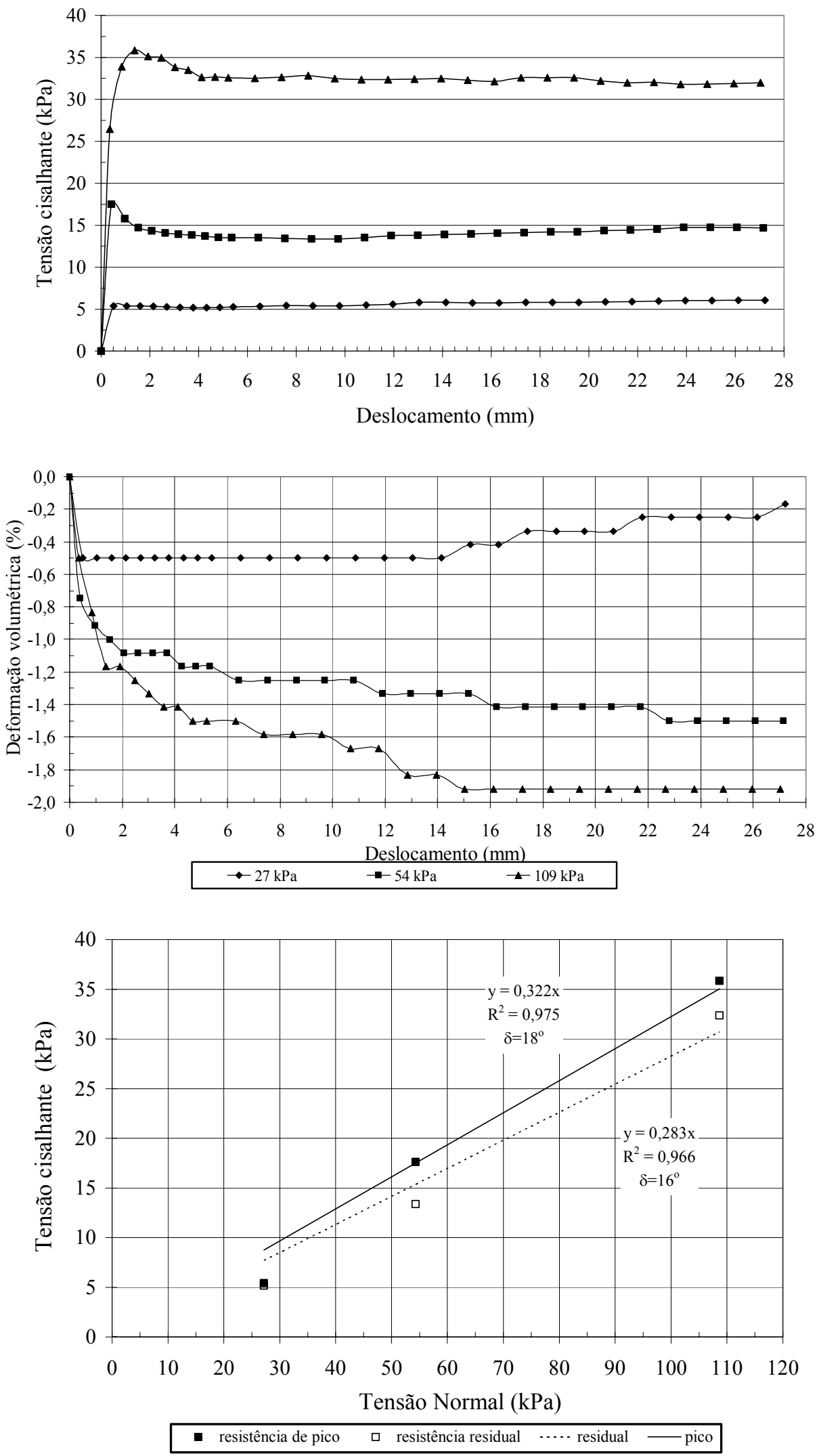

Figura B.8. Resultado dos ensaios de interface PEAD/areia-CR=0\%- $3^{a}$ série. 

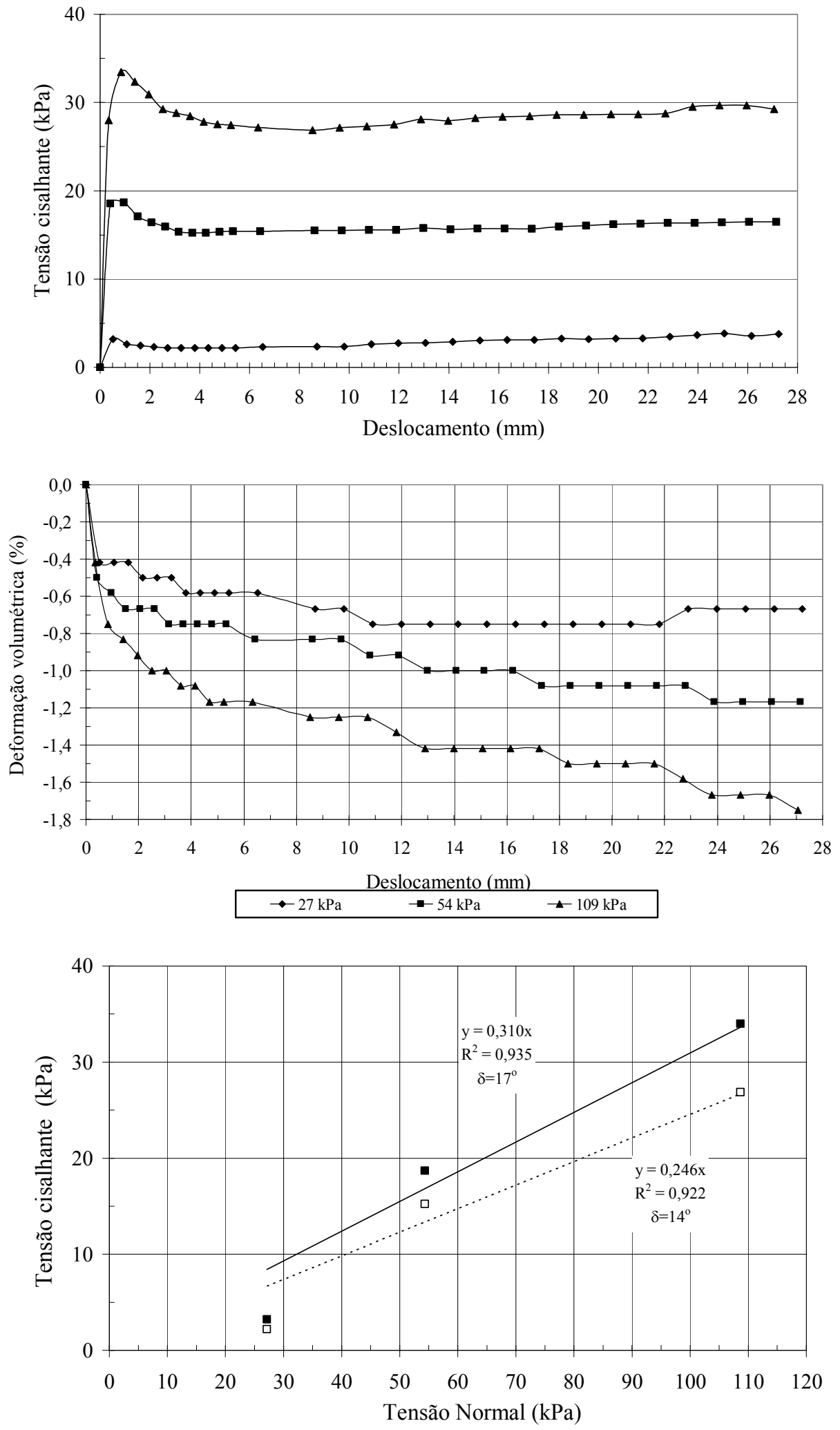

- resistência de pico $\square$ resistência residual $\cdots \cdot$... residual $\square$ pico

Figura B.9. Resultado dos ensaios de interface PEAD/areia-CR=57\%- $2^{a}$ série. 

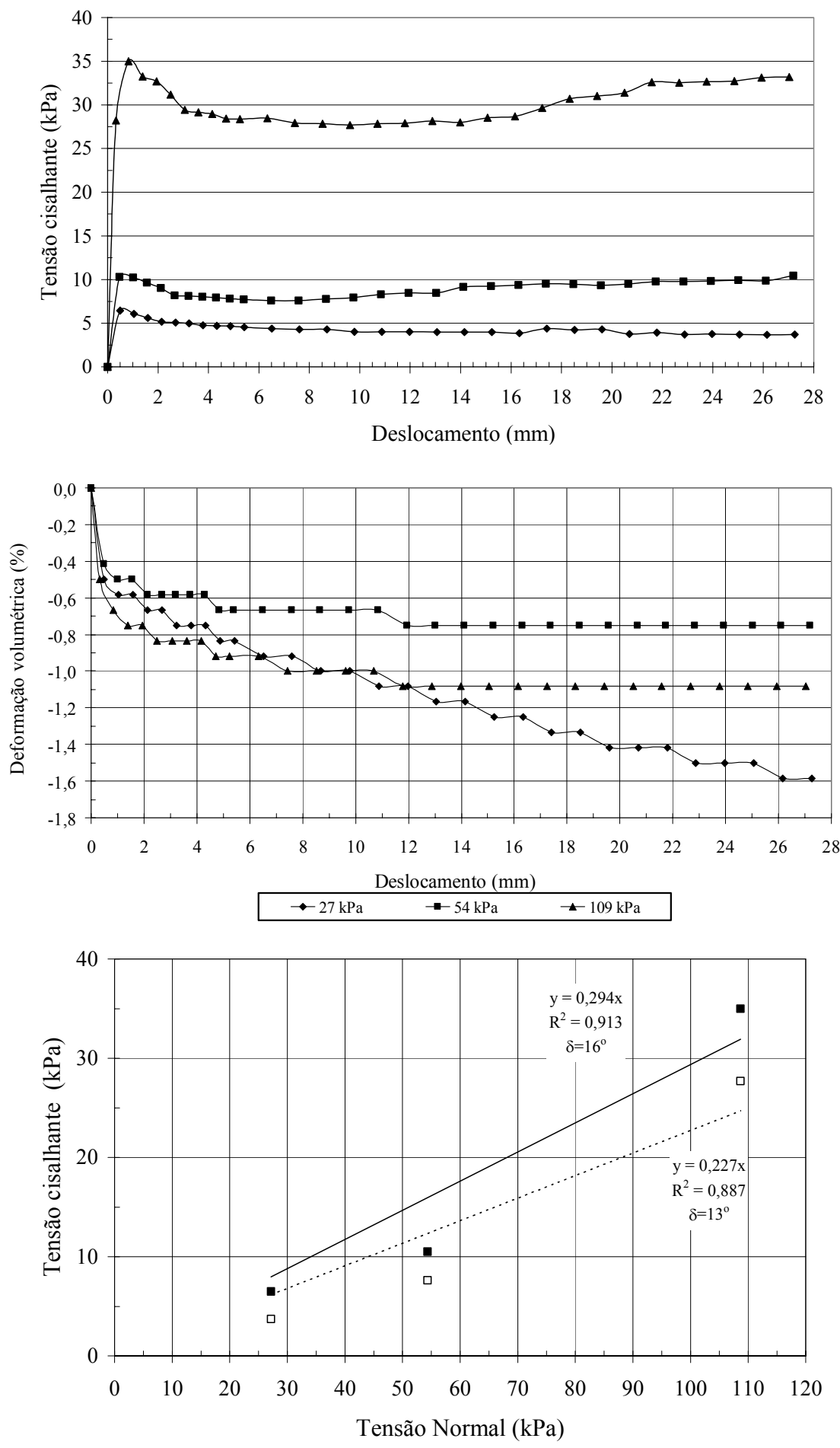

- resistência de pico $\quad \square \quad$ resistência residual $\cdots$.... residual $\longrightarrow$ pico

Figura B.10. Resultado dos ensaios de interface PEAD/areia-CR=57\%- $3^{a}$ série. 

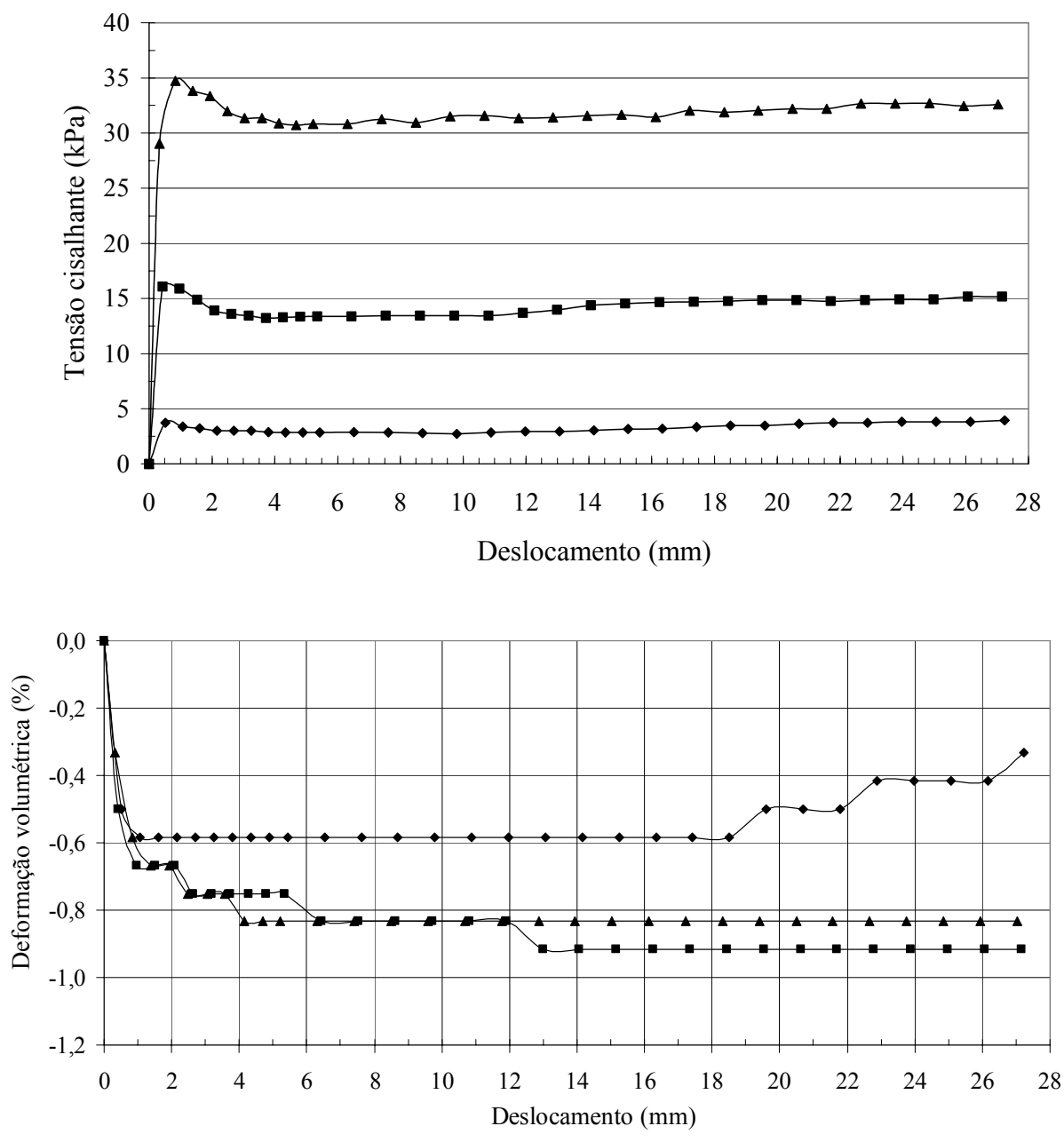

$\multimap-27 \mathrm{kPa} \rightarrow 54 \mathrm{kPa} \leftarrow 109 \mathrm{kPa}$

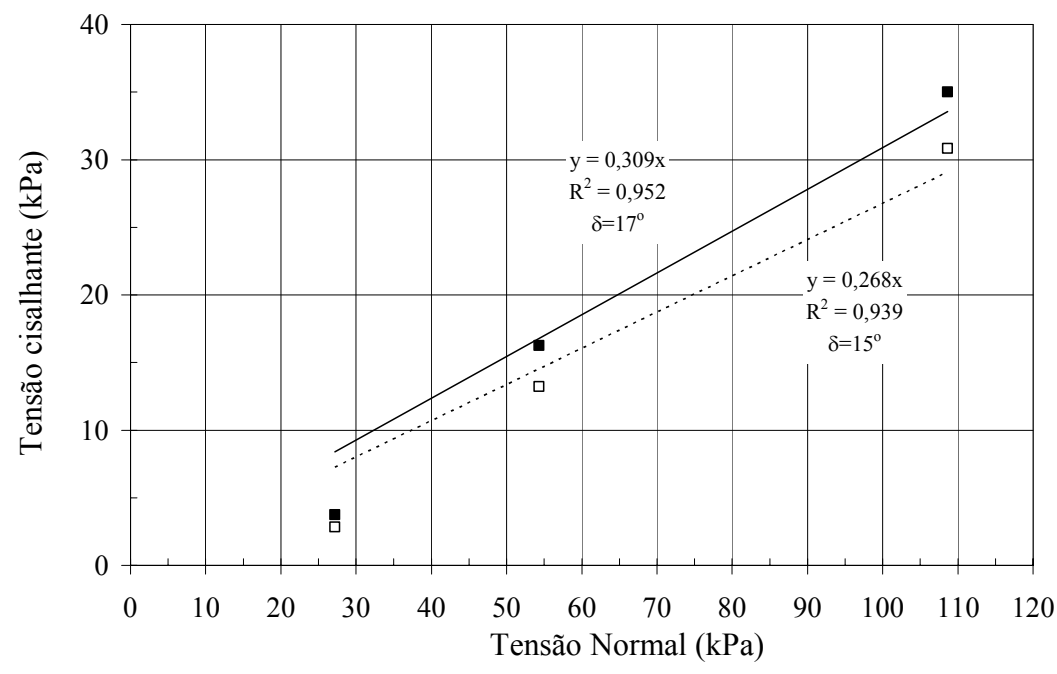

- resistência de pico $\quad \square \quad$ resistência residual $\cdots$... residual $\longrightarrow$ pico

Figura B.11. Resultado dos ensaios de interface PEAD/areia-CR=100\%- $2^{a}$ série. 

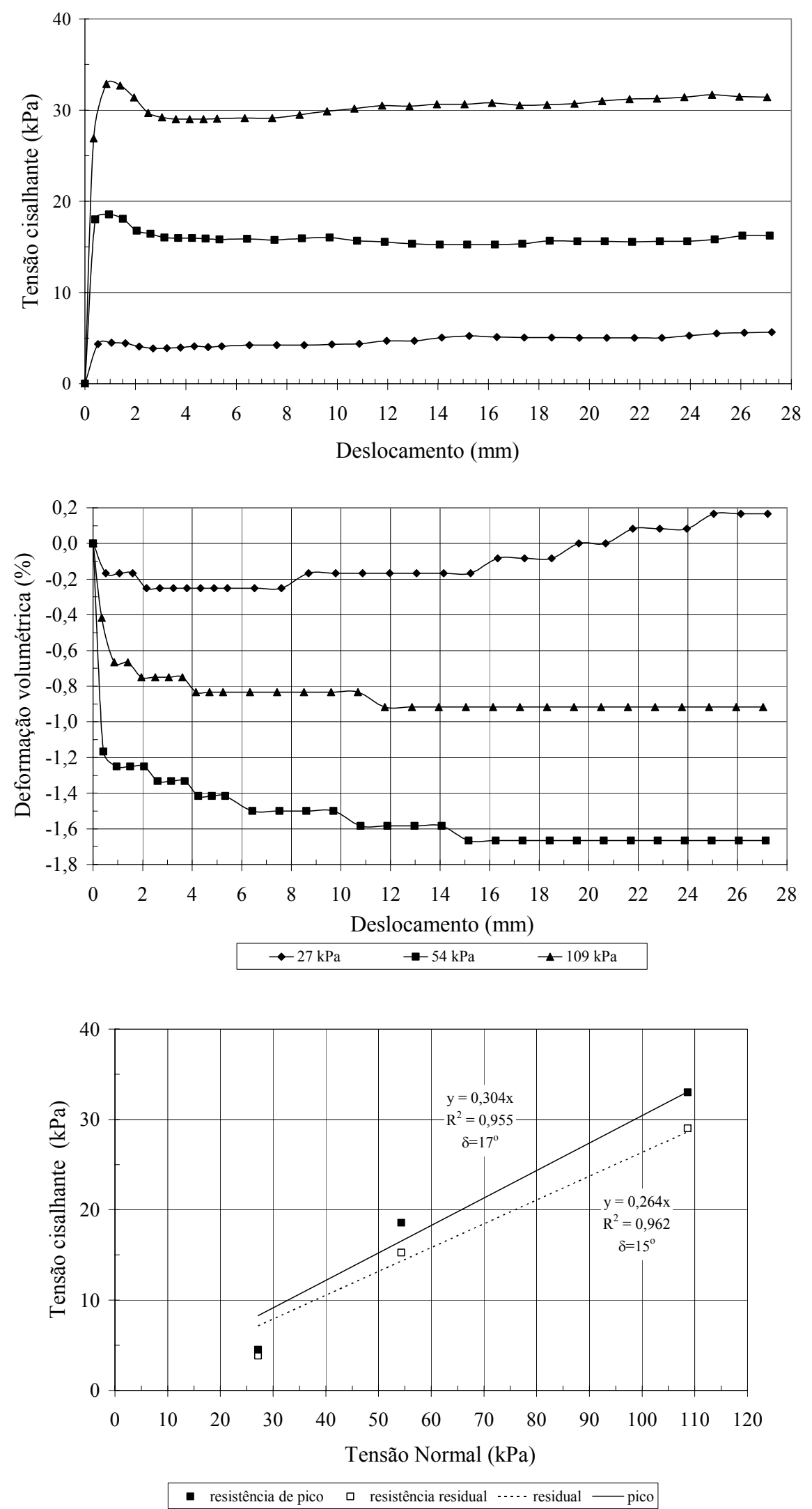

Figura B.12. Resultado dos ensaios de interface $P E A D /$ areia-CR $=100 \%-3^{a}$ série. 

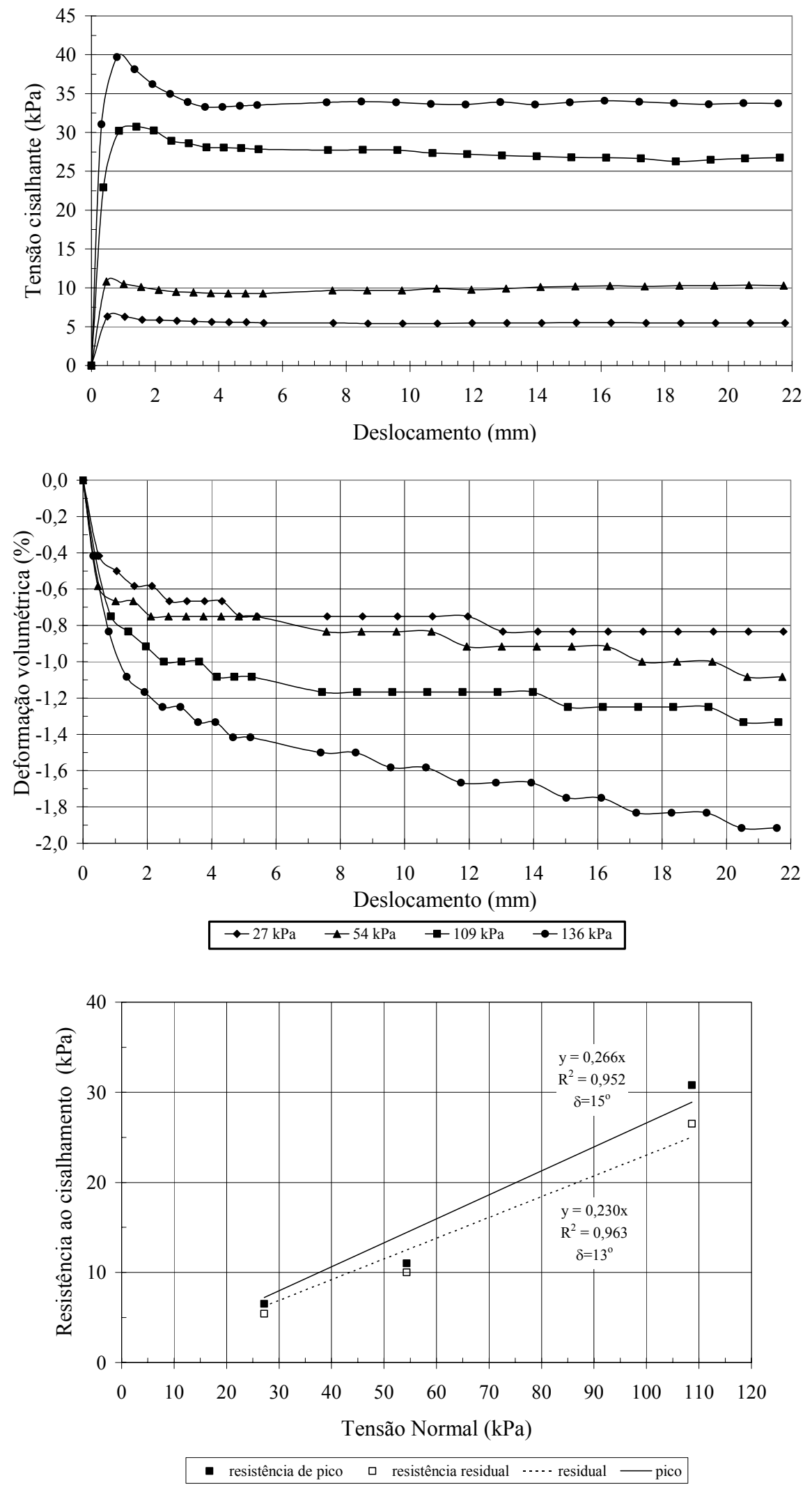

Figura B.13. Resultado dos ensaios de interface PELMD/areia-CR=0\%- $2^{a}$ série. 

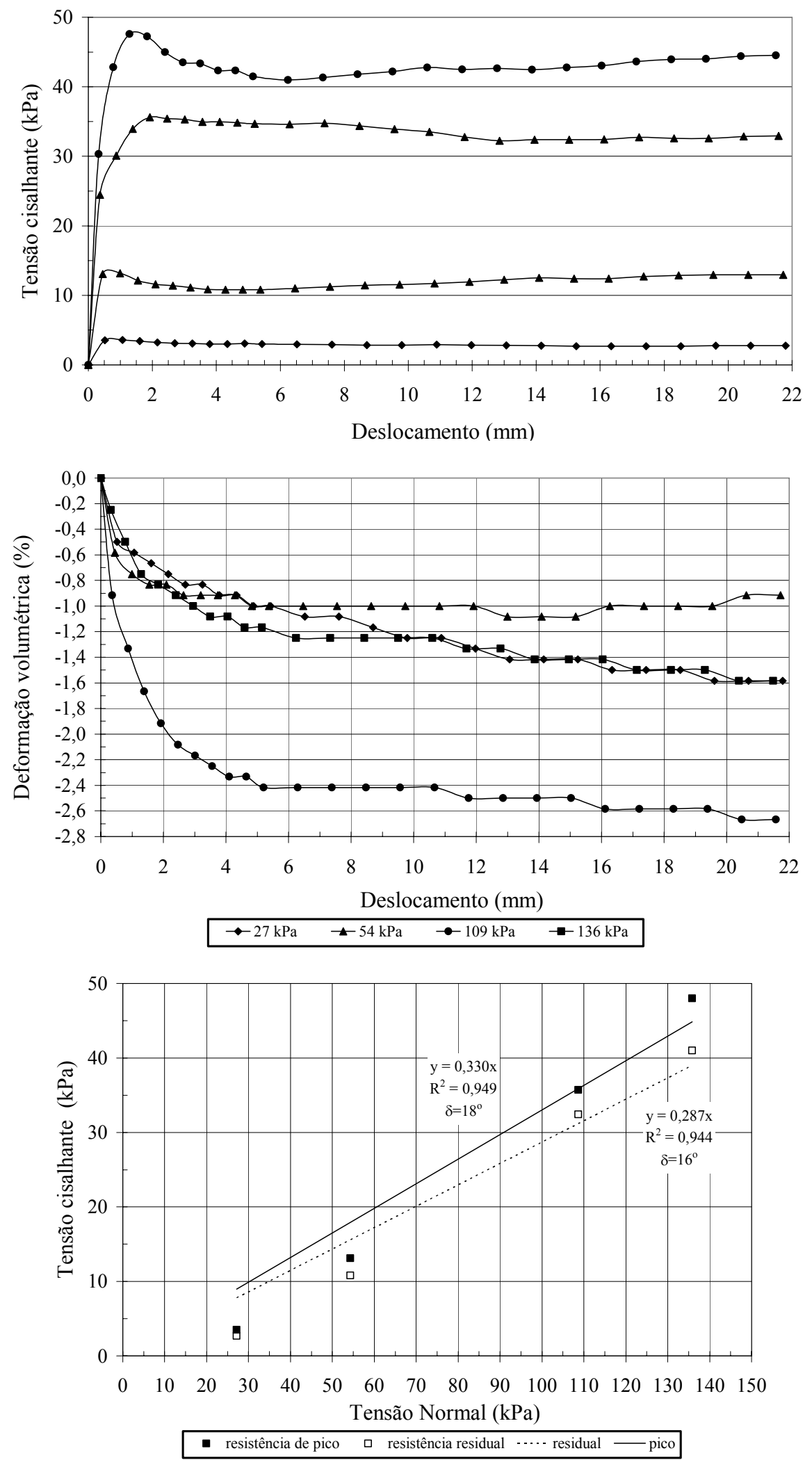

Figura B.14. Resultado dos ensaios de interface PELMD/areia-CR=0\%- $3^{a}$ série. 

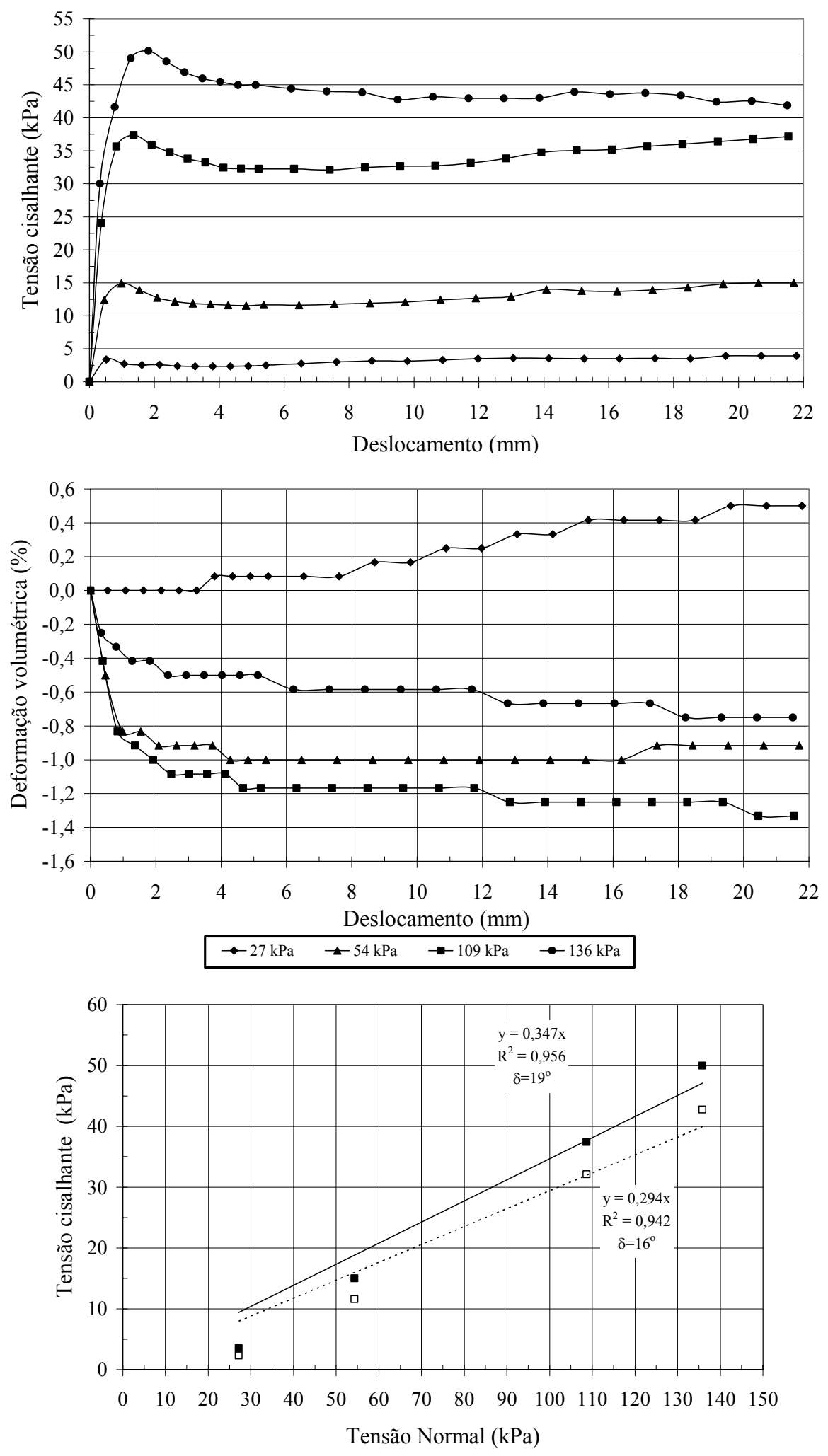

\begin{tabular}{lllll} 
- resistência de pico & $\square$ & resistência residual & $\cdots \cdot$ residual & - pico \\
\hline
\end{tabular}

Figura B.15. Resultado dos ensaios de interface PELMD/areia-CR=57\%- $2^{a}$ série. 

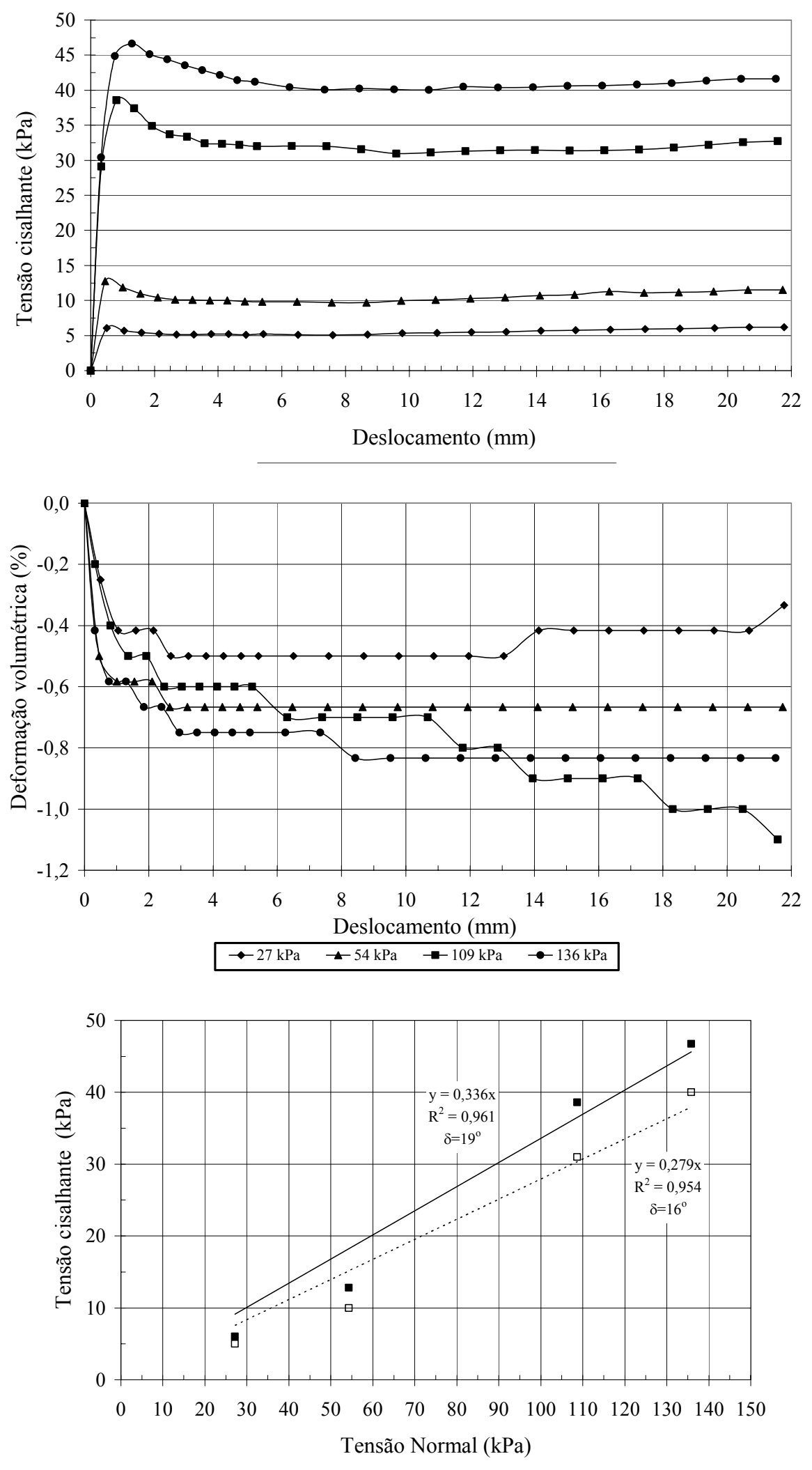

- resistência de pico $\quad \mathrm{a}$ resistência residual $\cdots$.... residual $\_$pico

Figura B.16. Resultado dos ensaios de interface PELMD/areia-CR=57\%- $3^{a}$ série. 

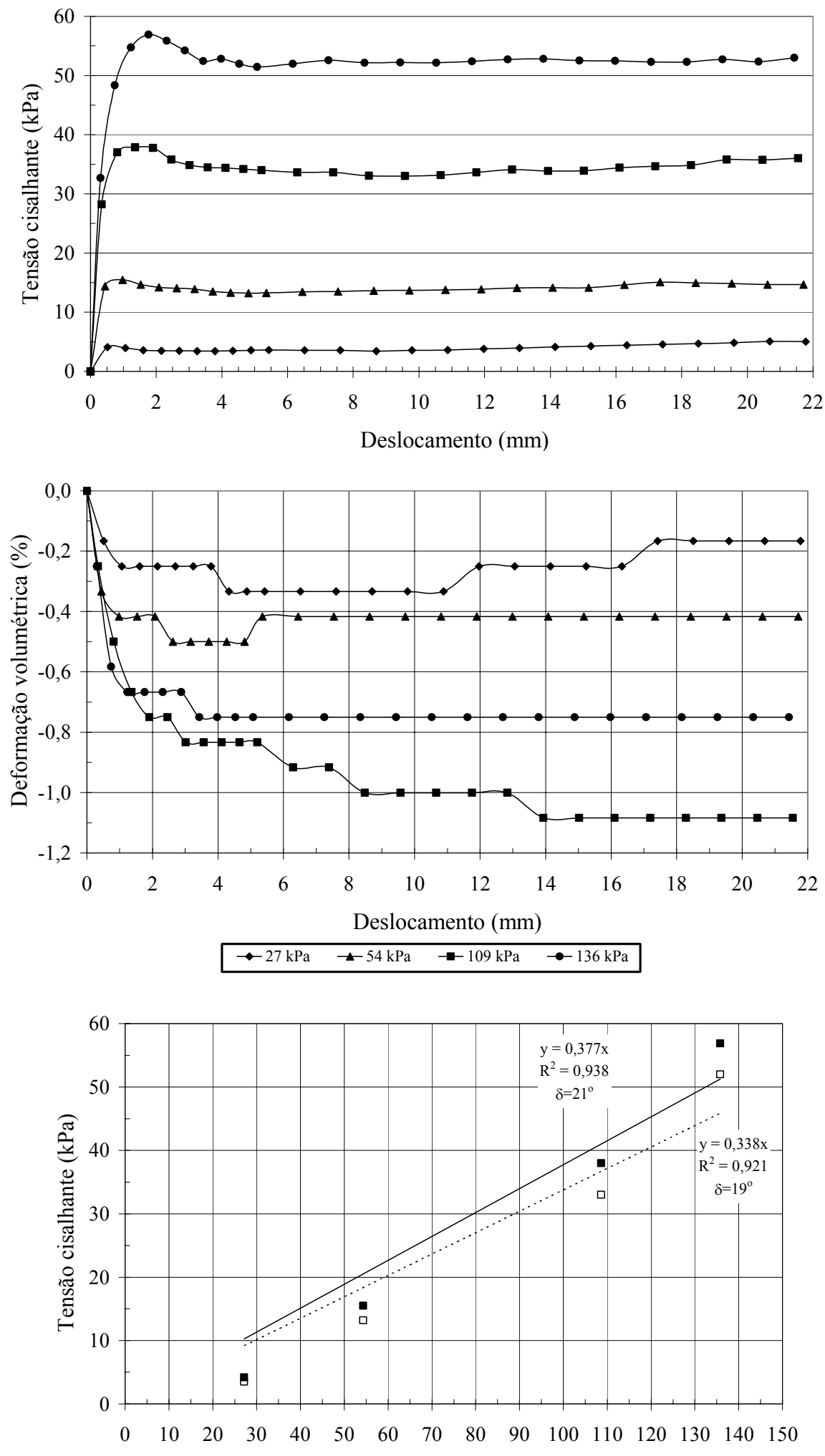

Tensão Normal (kPa)

- resistência de pico $\quad \square \quad$ resistência residual $\cdots \cdots$ residual $\square$ pico

Figura B.17. Resultado dos ensaios de interface PELMD/areia-CR=100\%- $2^{a}$ série. 

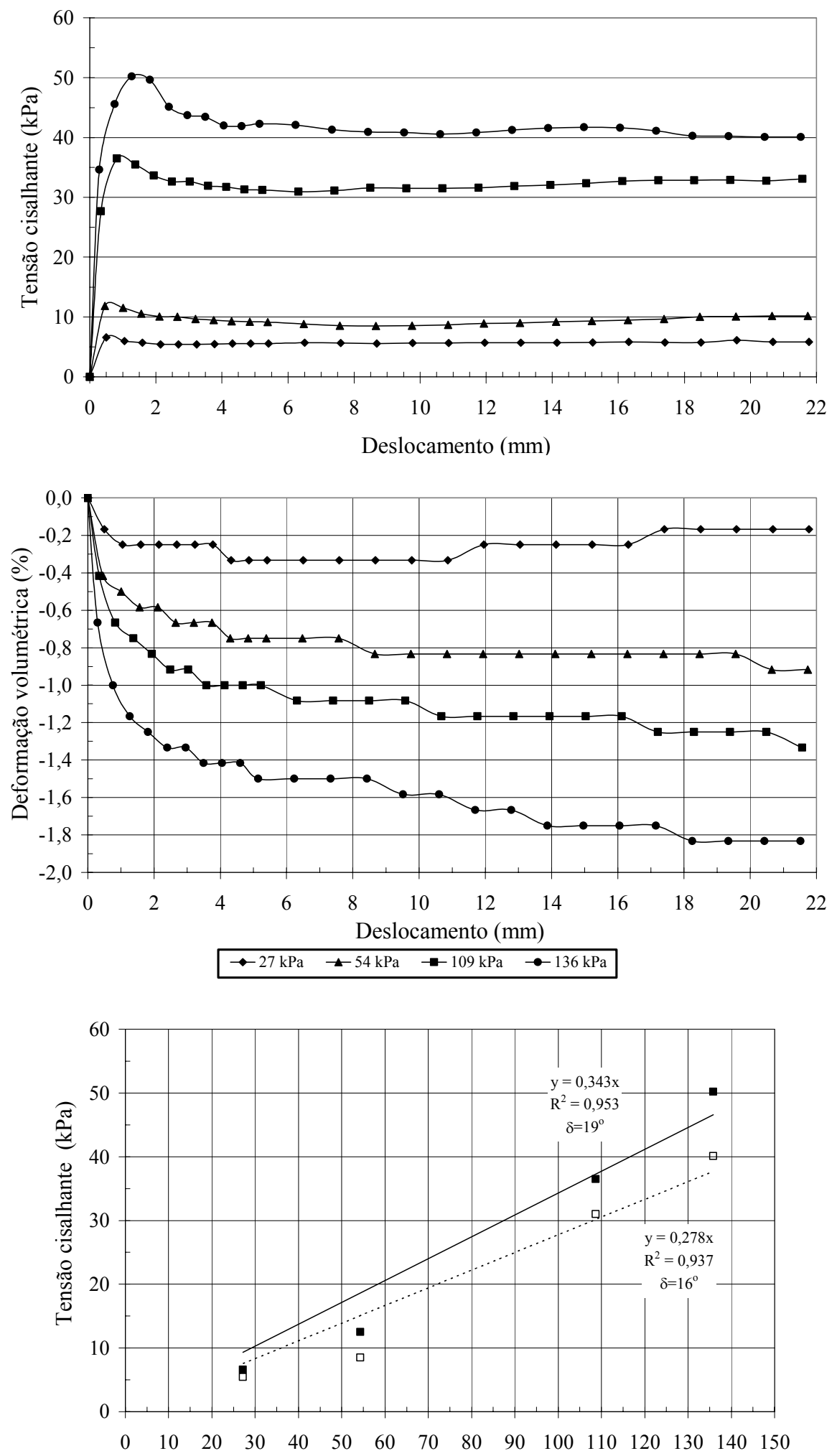

Tensão Normal (kPa)

- resistência de pico $\square$ resistência residual $\cdots \cdots$ residual $\quad-$ pico

Figura B.18. Resultado dos ensaios de interface PELMD/areia-CR=100\%- $3^{a}$ série 

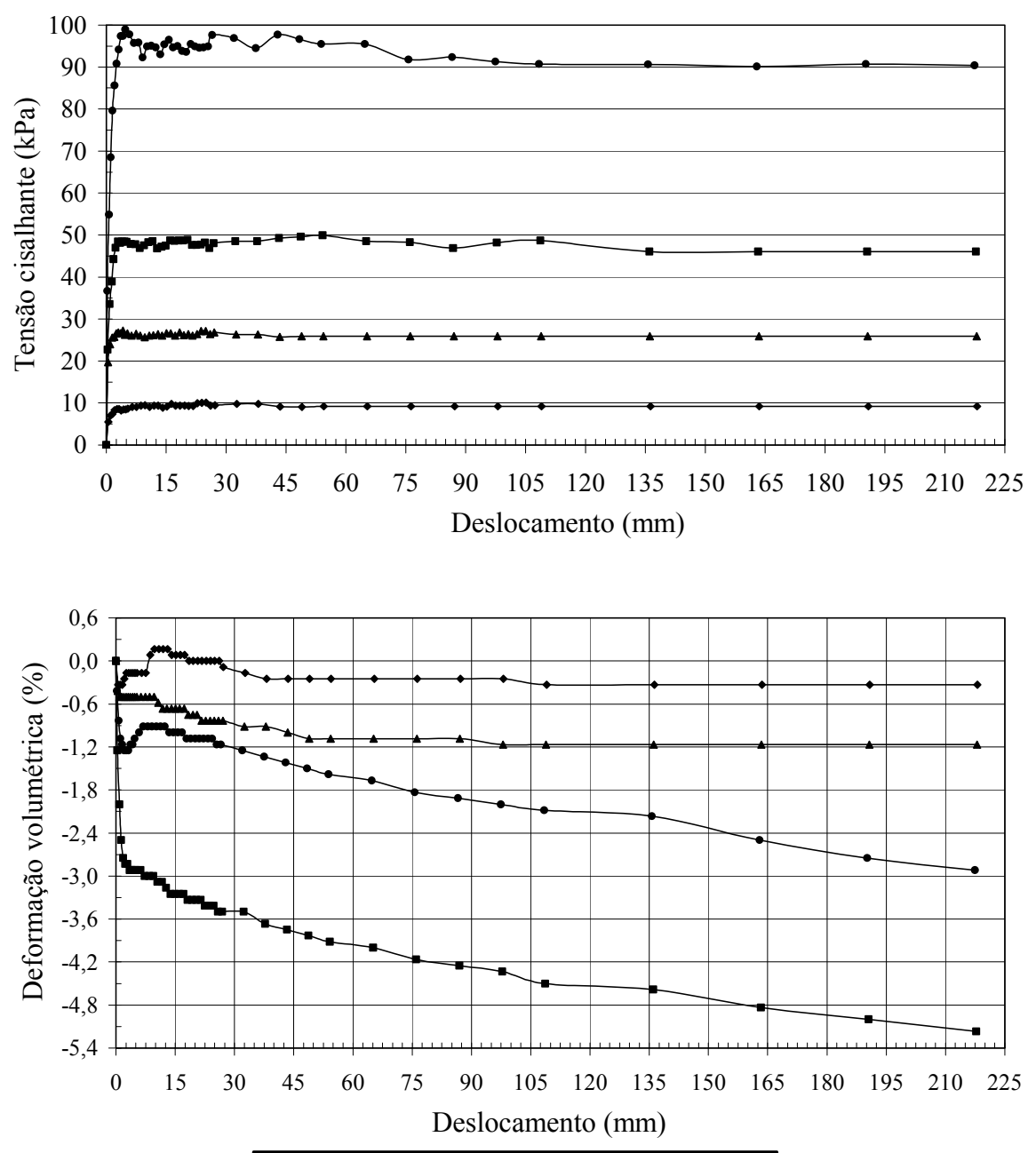

$\rightarrow-27 \mathrm{kPa} \quad \leftarrow 54 \mathrm{kPa} \quad \rightarrow-109 \mathrm{kPa} \quad \rightarrow-154 \mathrm{kPa}$

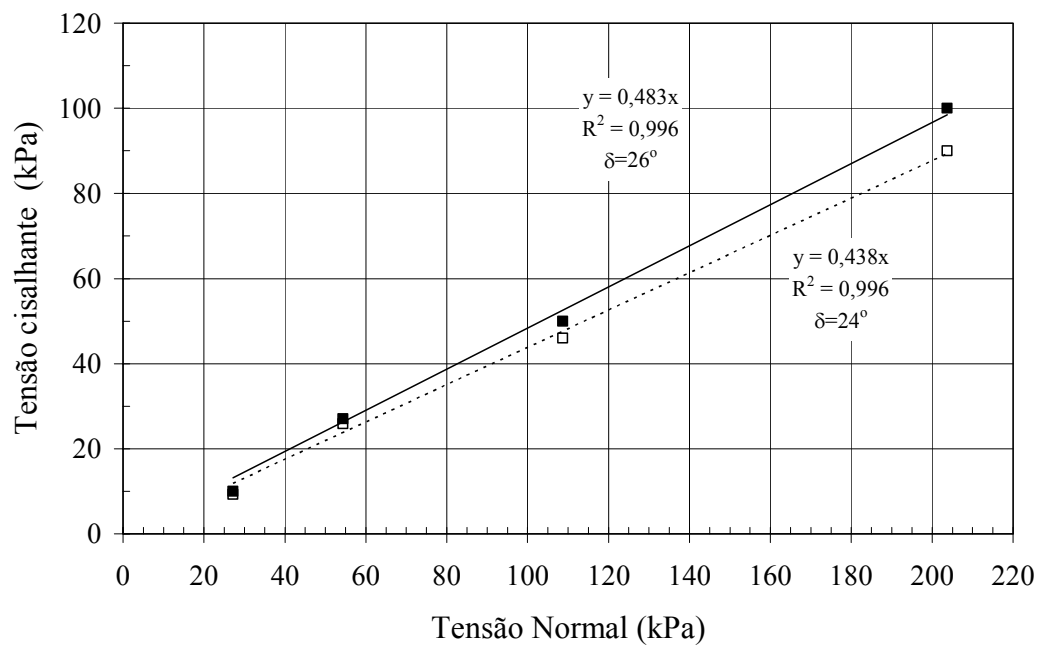

- resistência de pico $\quad \square \quad$ resistência residual $\cdots \cdots$ residual $\square$ pico

Figura B.19. Resultado dos ensaios de interface PEAD A/areia-CR=0\%- $2^{a}$ série. 

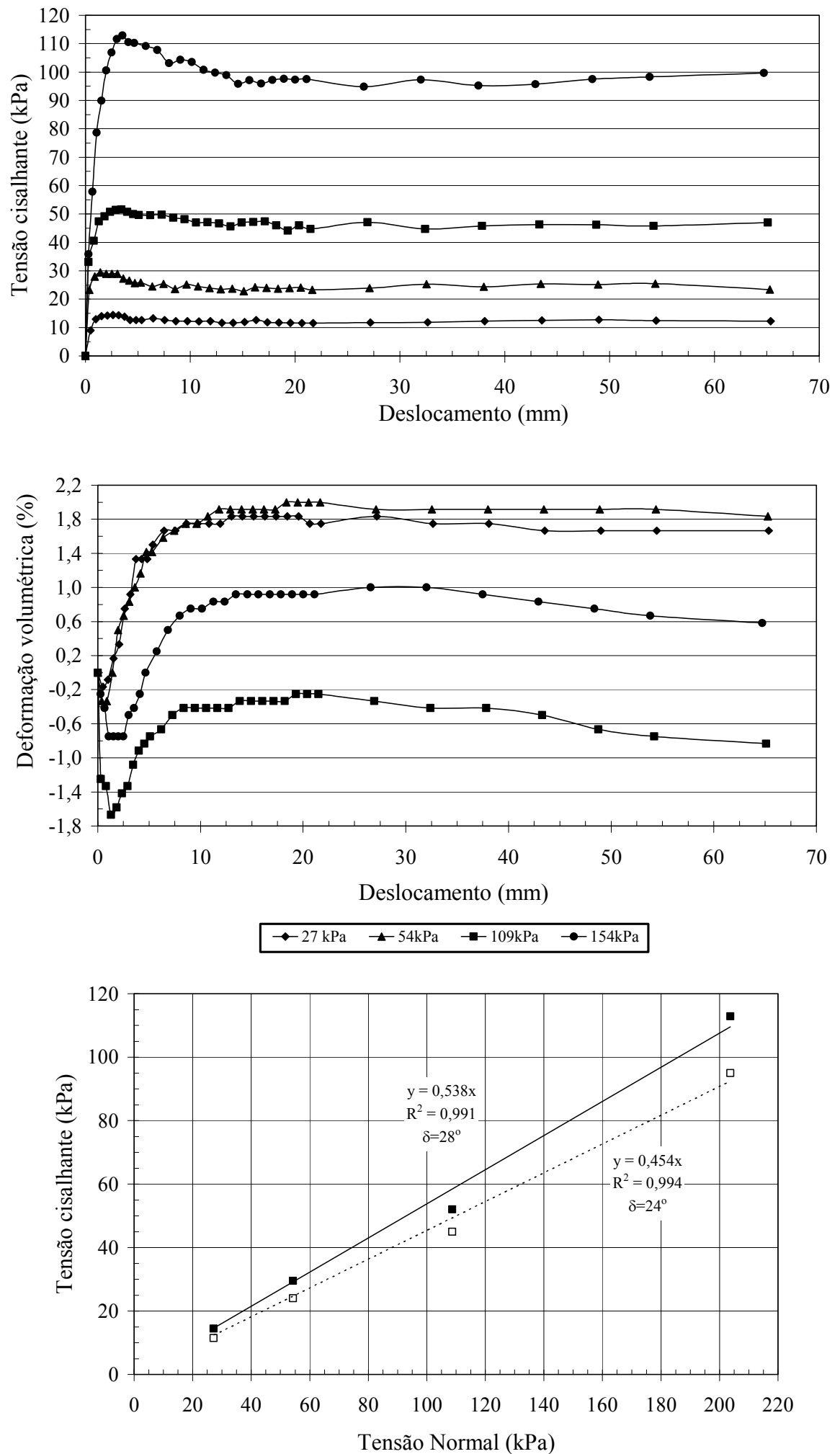

- resistência de pico $\square$ resistência residual... residual $—$ pico

Figura B.20. Resultado dos ensaios de interface PEAD A/areia-CR=57\%- $2^{a}$ série. 

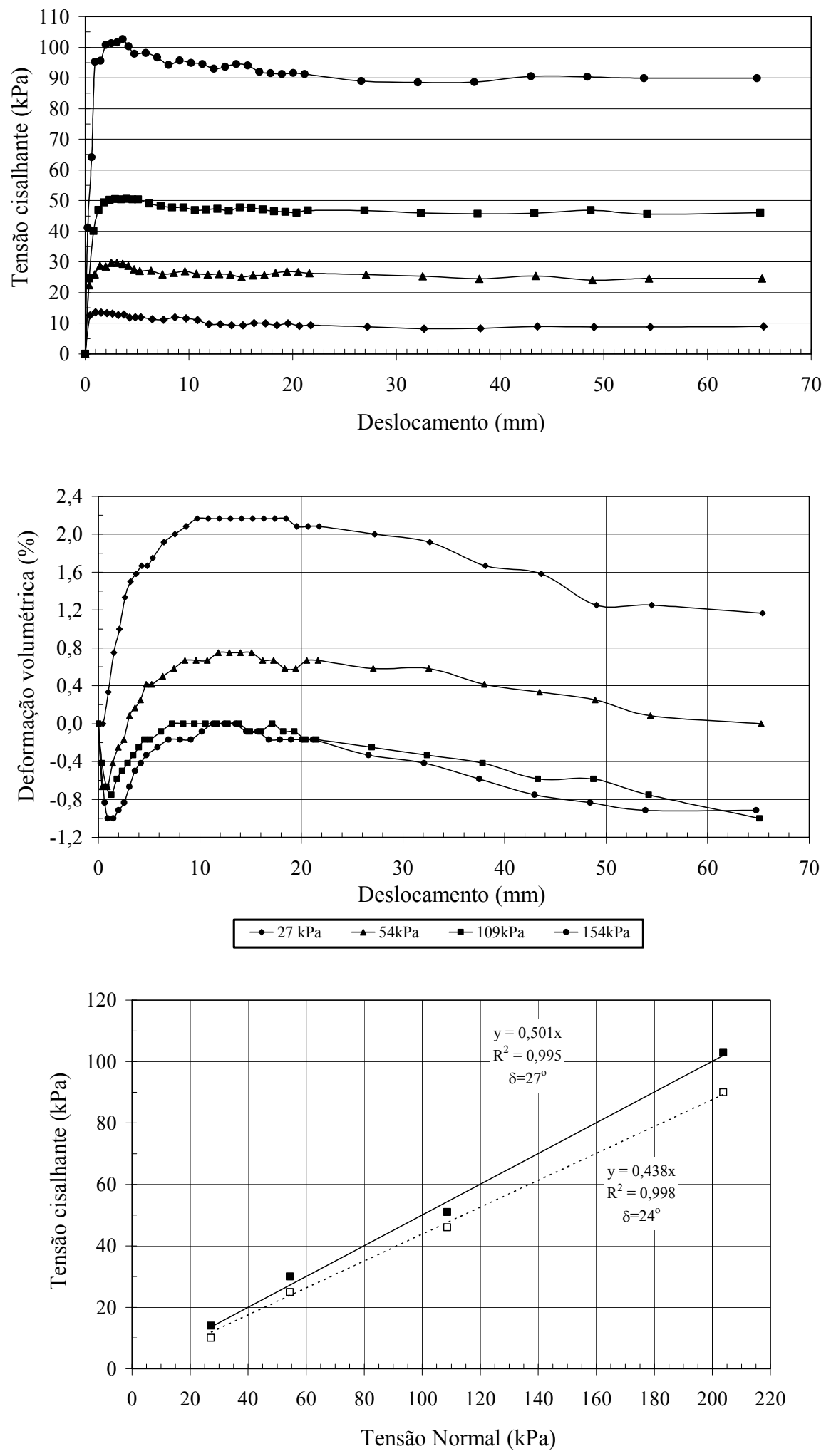

- resistência de pico $\quad \square \quad$ resistência residual $\cdots \cdots$ residual $—$ pico

Figura B.21. Resultado dos ensaios de interface PEAD A/areia-CR=100\%- $2^{a}$ série. 

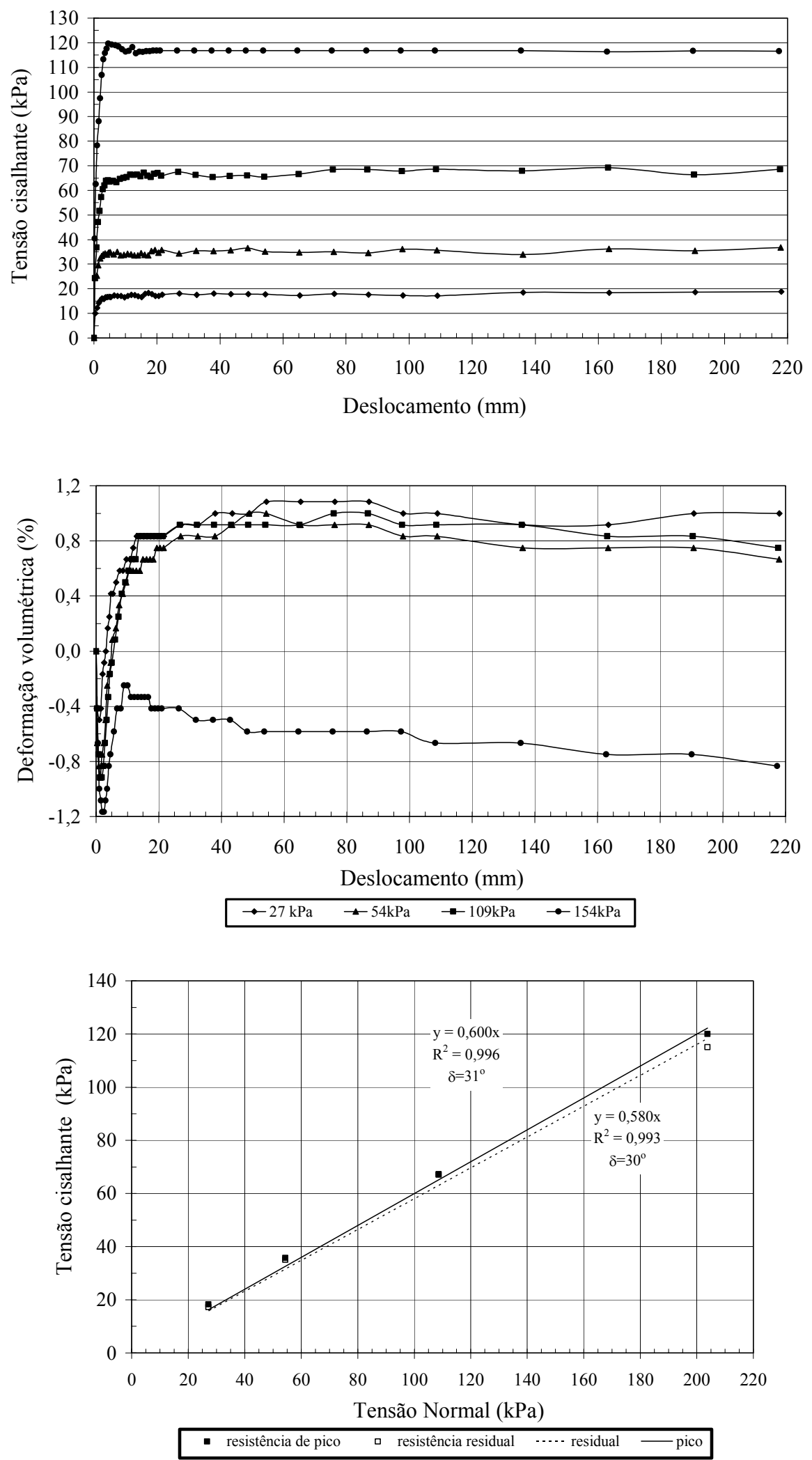

Figura B.22. Resultado dos ensaios de interface PEAD AR/areia-CR=0\%- $2^{a}$ série. 

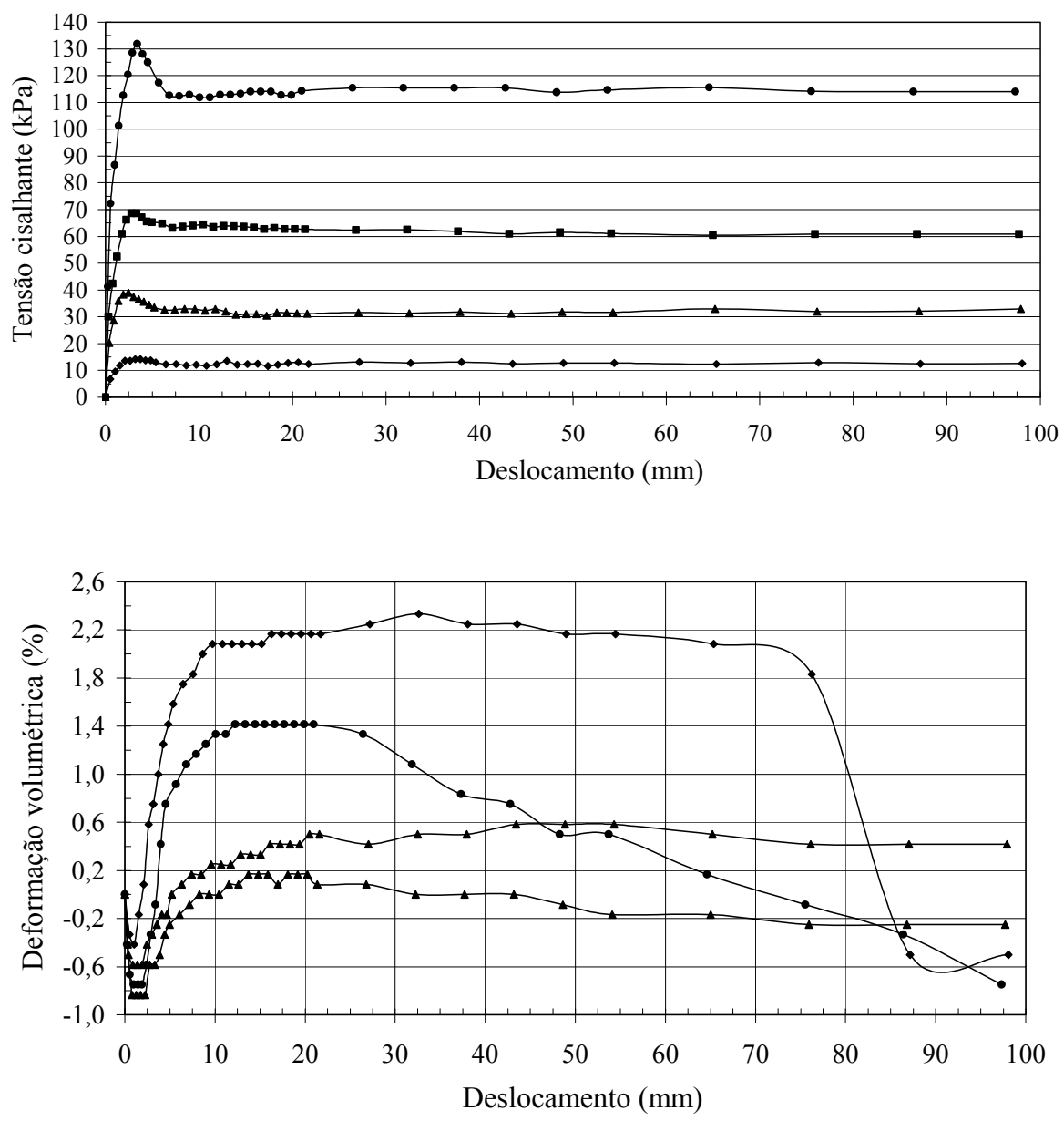

$\bullet-27 \mathrm{kPa} \quad \leftarrow 54 \mathrm{kPa} \quad \leftarrow 109 \mathrm{kPa} \quad \bullet 154 \mathrm{kPa}$

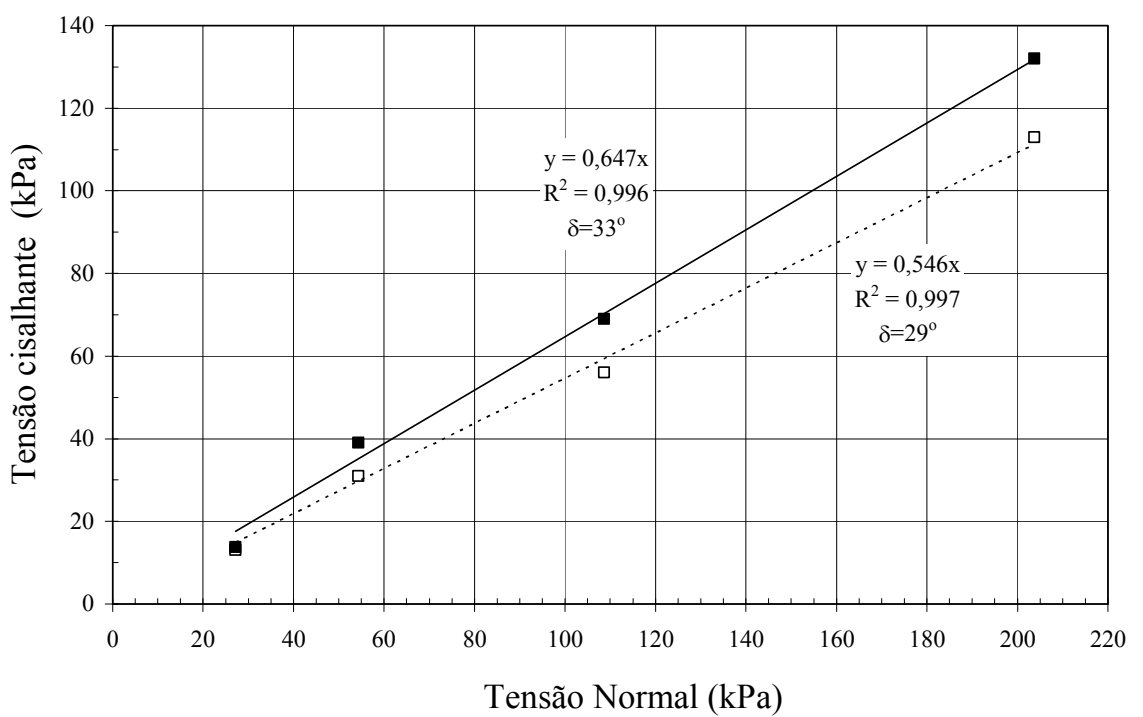

- resistência de pico $\quad \square \quad$ resistência residual $\cdots$...- residual $\square$ pico

Figura B.23. Resultado dos ensaios de interface PEAD AR/areia-CR=57\%- $2^{a}$ série. 

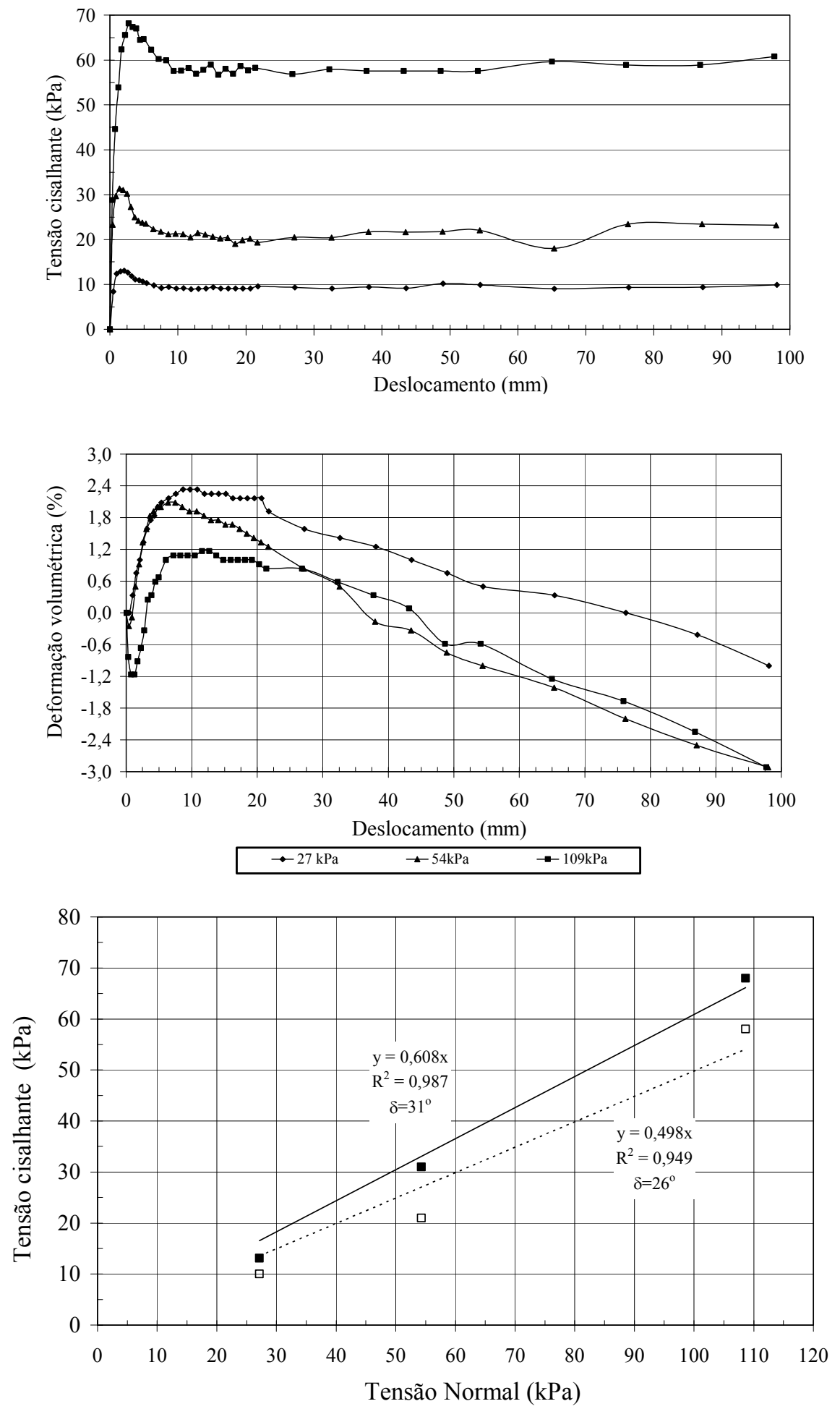

- resistência de pico $\quad \square \quad$ resistência residual $\cdots \cdot$ residual - pico

Figura B.24. Resultado dos ensaios de interface PEAD AR/areia-CR=100\%- $2^{a}$ série. 
APÊNDICE C- Resultados dos Ensaios de Interface em Materiais Granulares- Ensaios de cisalhamento direto.
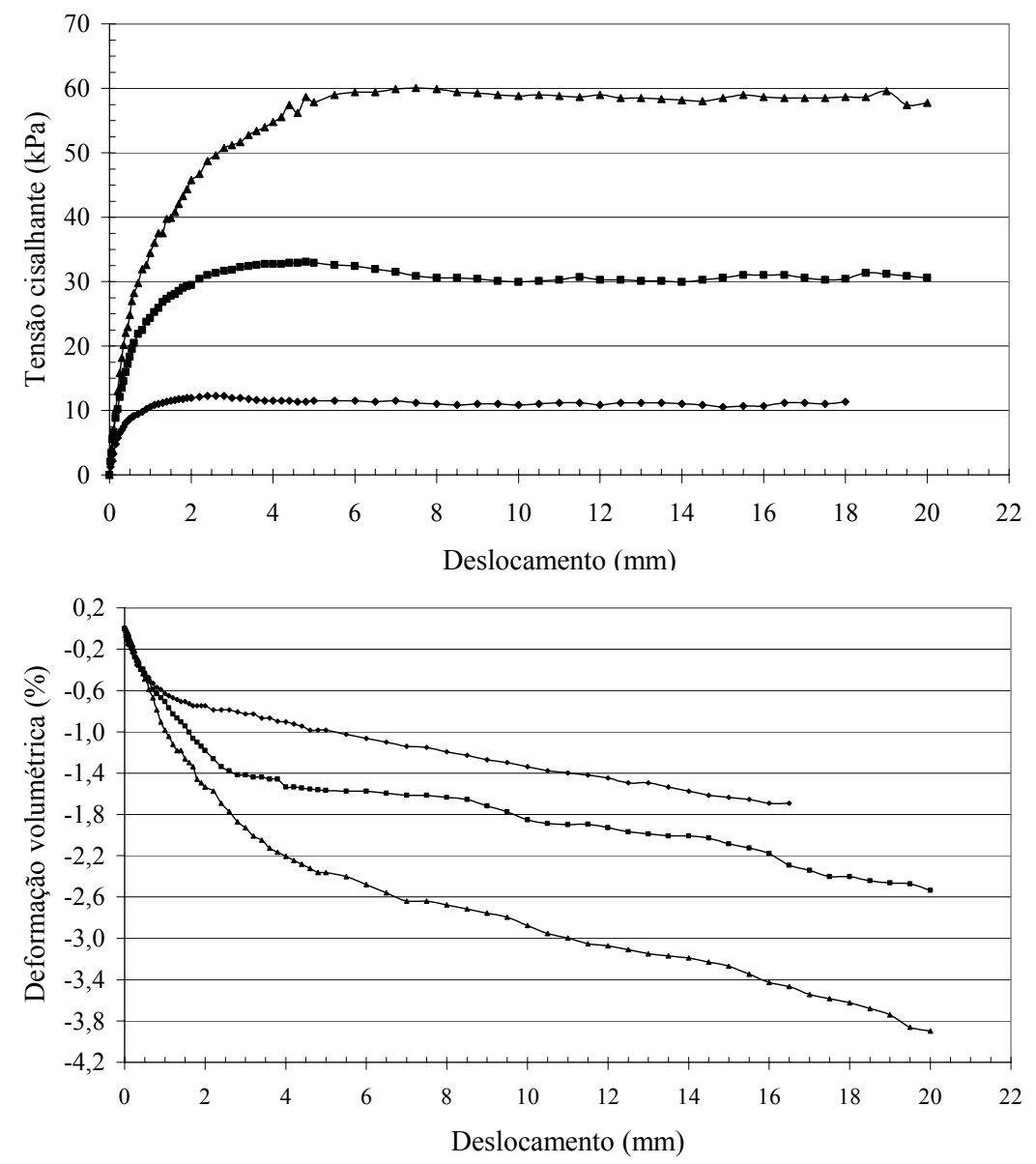

$\rightarrow 30 \mathrm{kPa} \rightarrow 54 \mathrm{kPa} \rightarrow 113 \mathrm{kPa}$

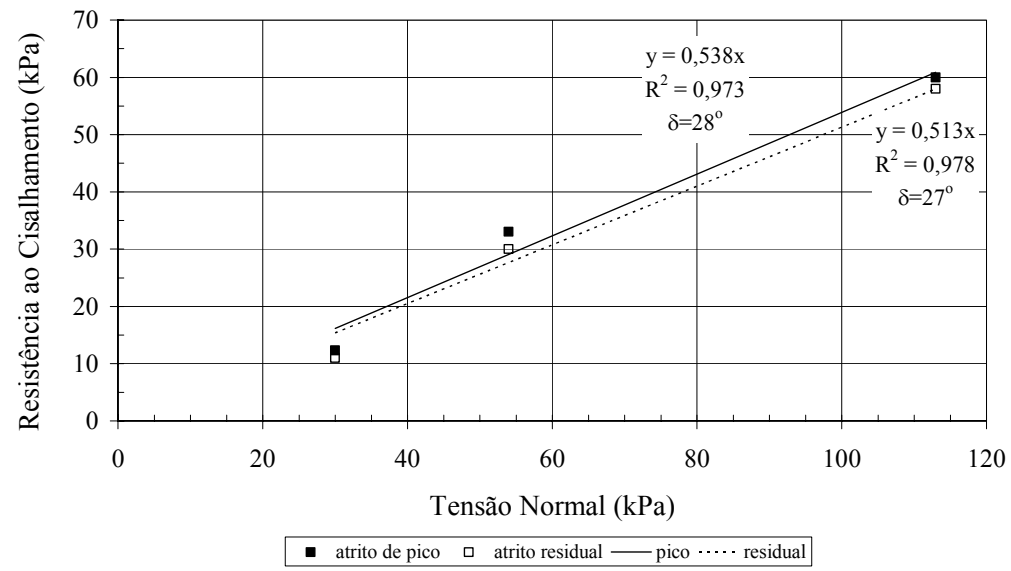

Figura C.1. Resultados dos ensaios de interface PVC/areia- $C R=0 \%$. 

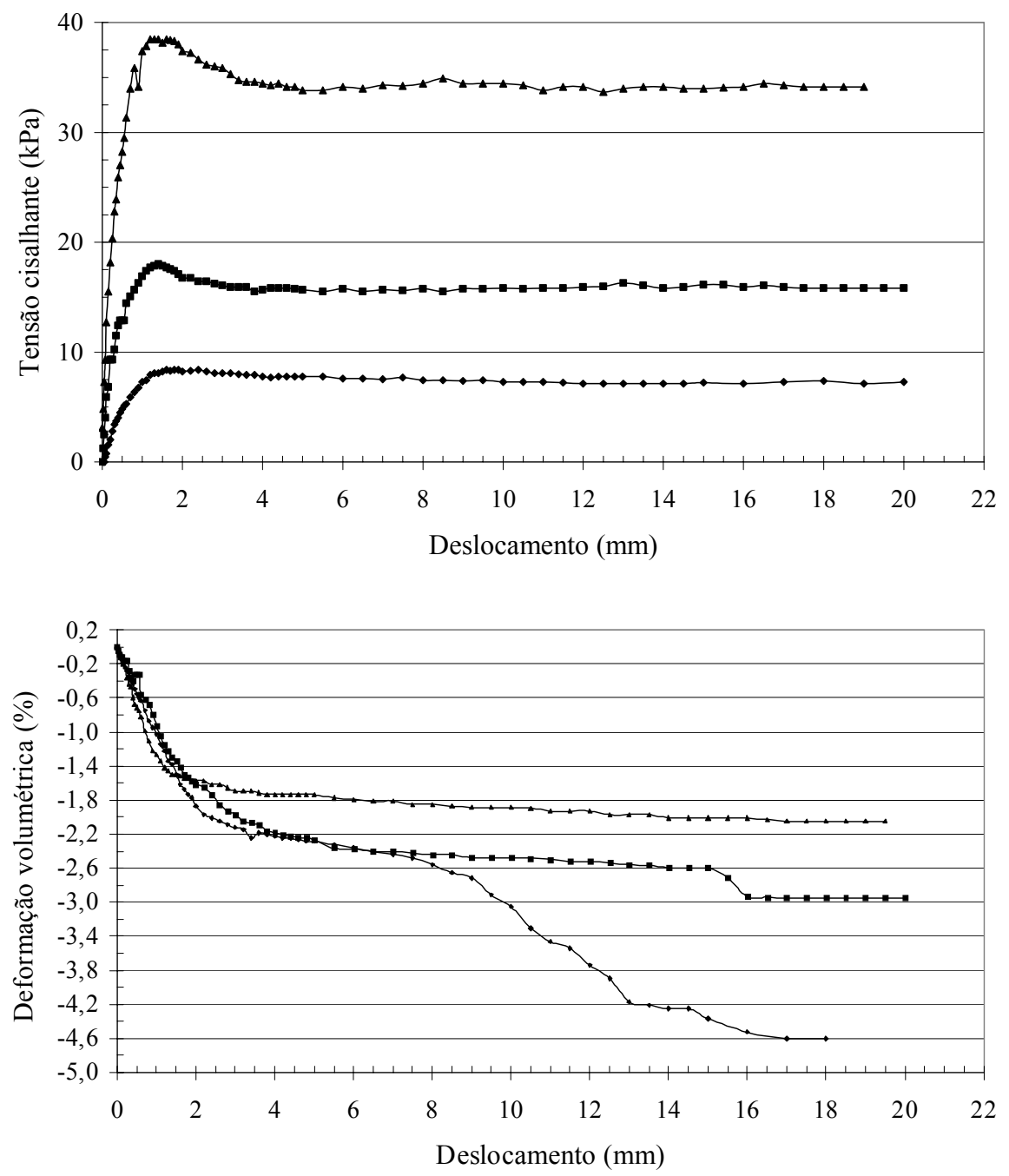

$\rightarrow 30 \mathrm{kPa} \rightarrow 65 \mathrm{kPa} \rightarrow 113 \mathrm{kPa}$

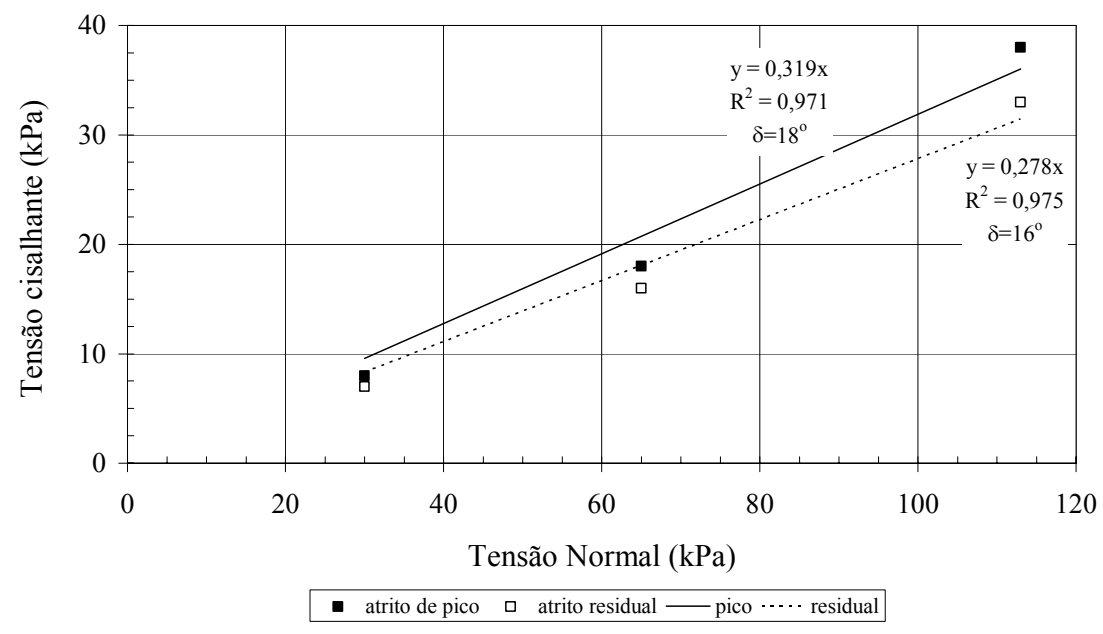

Figura C.2. Resultados dos ensaios de interface PEAD/areia- $C R=0 \%$. 

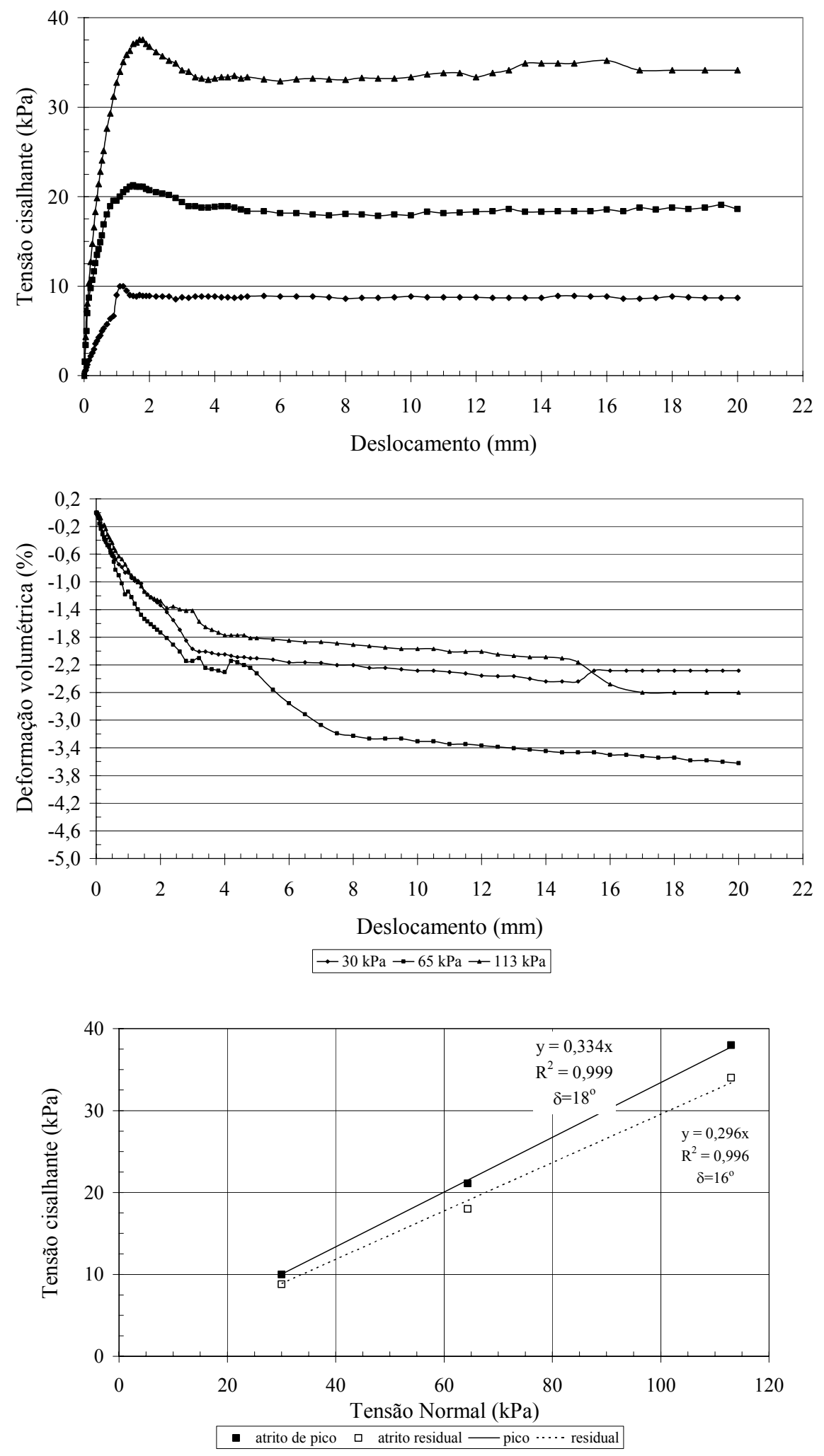

Figura C.3. Resultados dos ensaios de interface PE linear/areia- $C R=0 \%$. 

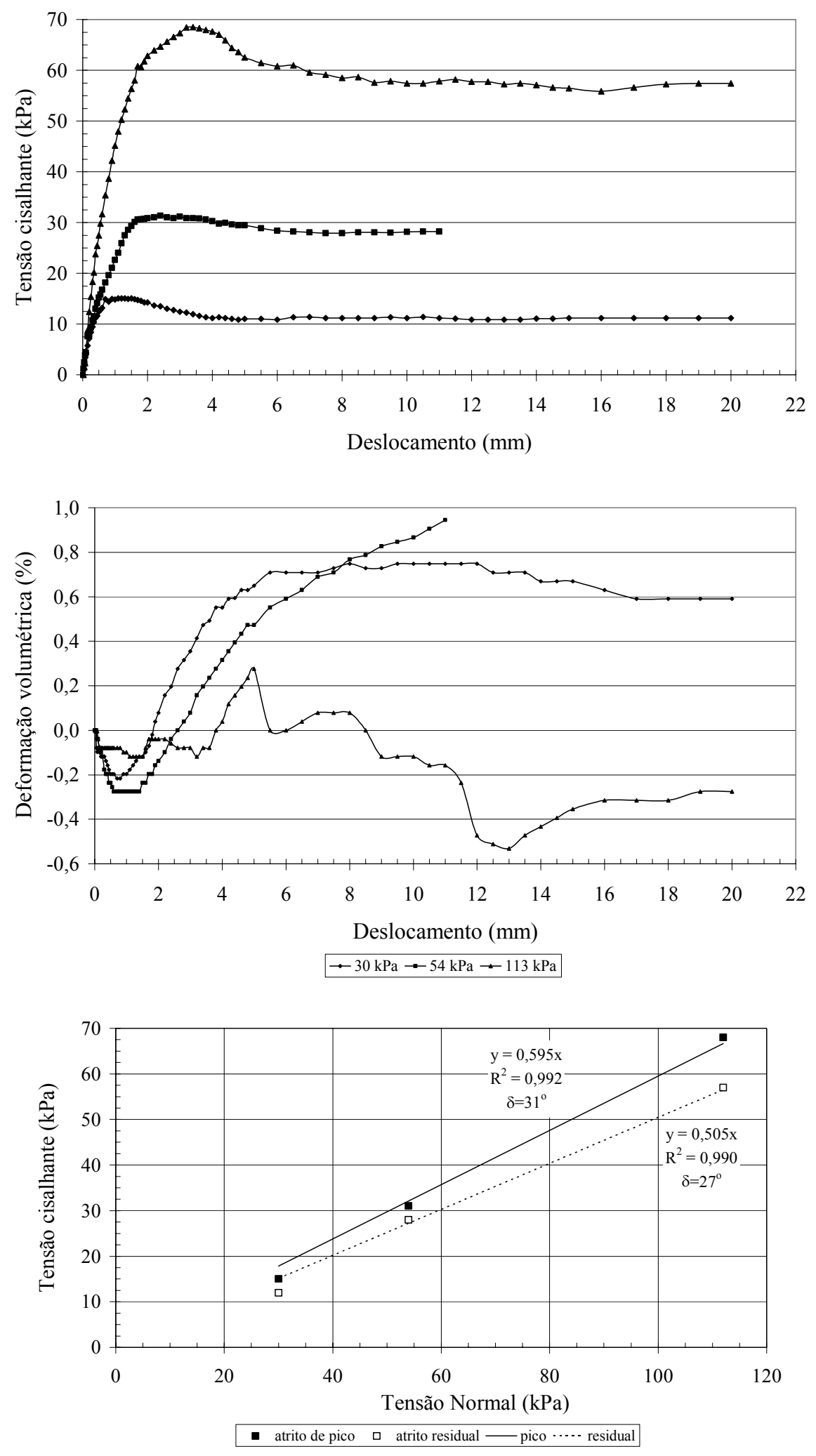

Figura C.4. Resultados dos ensaios de interface PEAD A/areia- $C R=0 \%$. 

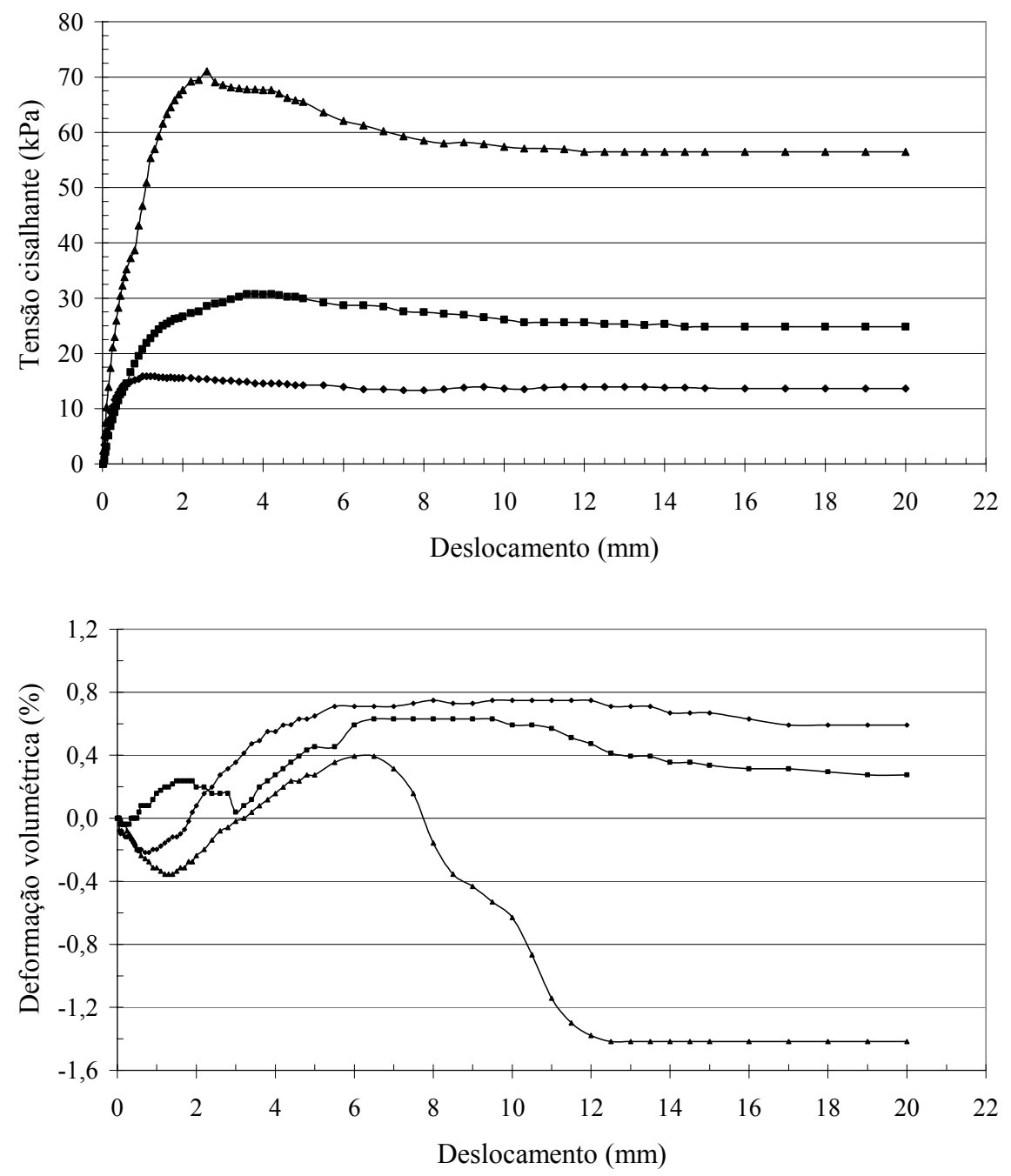

$\rightarrow 30 \mathrm{kPa} \rightarrow 54 \mathrm{kPa} \rightarrow 113 \mathrm{kPa}$

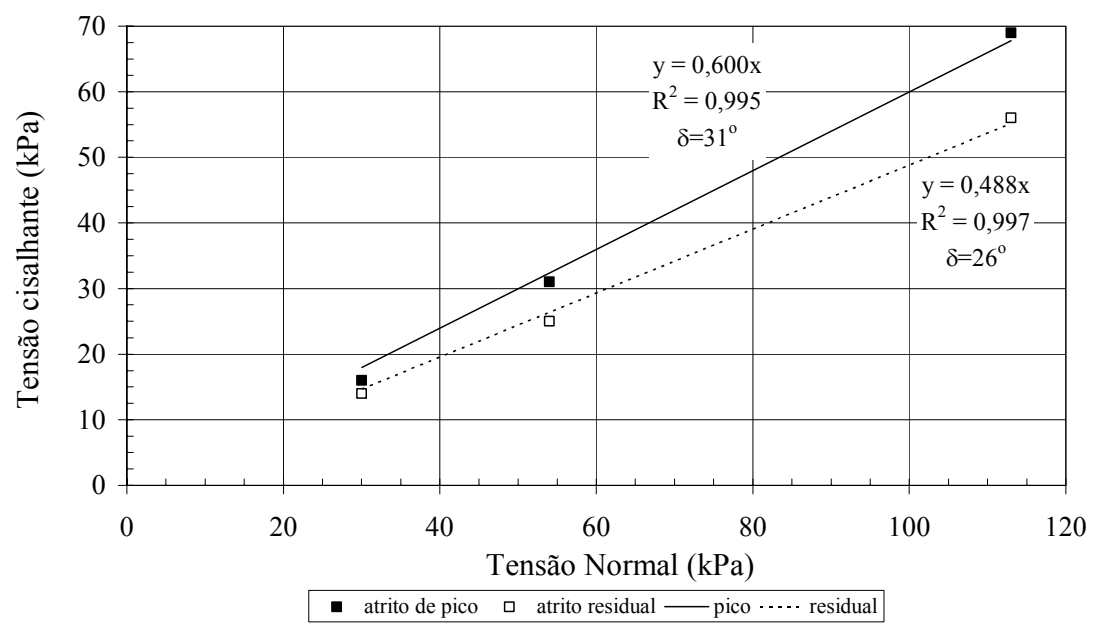

Figura C.5. Resultados dos ensaios de interface PEAD AR/areia- $C R=0 \%$. 
ANEXO. Curva de compactação do solo argiloso (amostra dois)

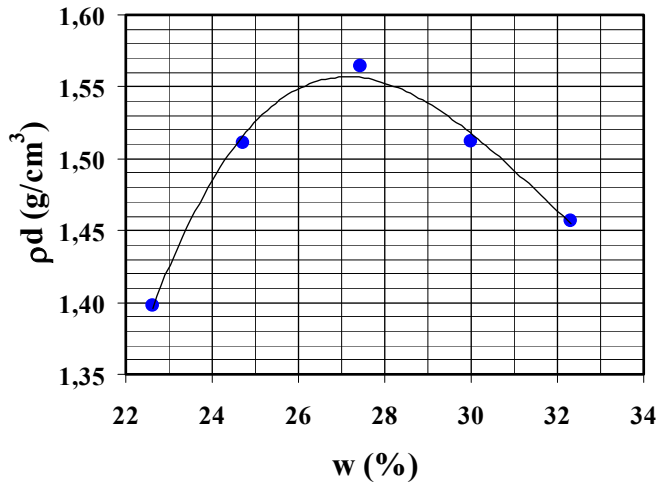

(a)

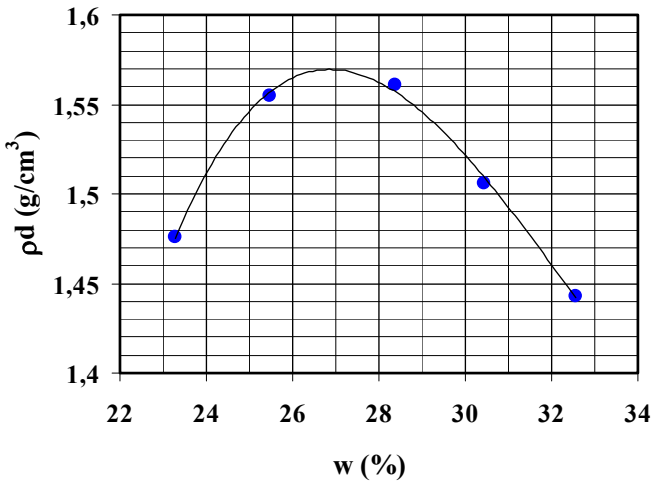

(b)

Figura A.1. Curvas de compactação (a) SP 01; (b) SP 05. 